\title{
In Search of a Dream America: Place-connectedness in East European Immigrant Life Writing
}

Irina V. Rodimtseva

West Virginia University

Follow this and additional works at: https://researchrepository.wvu.edu/etd

\section{Recommended Citation}

Rodimtseva, Irina V., "In Search of a Dream America: Place-connectedness in East European Immigrant Life Writing" (2012). Graduate Theses, Dissertations, and Problem Reports. 4913.

https://researchrepository.wvu.edu/etd/4913

This Dissertation is protected by copyright and/or related rights. It has been brought to you by the The Research Repository @ WVU with permission from the rights-holder(s). You are free to use this Dissertation in any way that is permitted by the copyright and related rights legislation that applies to your use. For other uses you must obtain permission from the rights-holder(s) directly, unless additional rights are indicated by a Creative Commons license in the record and/ or on the work itself. This Dissertation has been accepted for inclusion in WVU Graduate Theses, Dissertations, and Problem Reports collection by an authorized administrator of The Research Repository @ WVU.

For more information, please contact researchrepository@mail.wvu.edu. 
In Search of a Dream America:

Place-connectedness in East European Immigrant Life Writing

\title{
Irina V. Rodimtseva
}

\author{
Dissertation submitted to the \\ Eberly College of Arts and Sciences \\ at West Virginia University \\ in partial fulfillment of the requirements \\ for the degree of \\ Doctor of Philosophy \\ in \\ English
}

Kathleen Ryan, Ph.D., Chair

Gwen Bergner, Ph.D.

Cari Carpenter, Ph.D.

Nancy Condee, Ph.D.

Timothy Sweet, Ph.D.

Department of English

Morgantown, West Virginia

2012

Key words: American literature, immigrant literature, place, the American Dream, Eastern Europe, autobiography and life writing 


\begin{abstract}
In Search of a Dream America:

Place-connectedness in East European Immigrant Life Writing

Irina V. Rodimtseva
\end{abstract}

Theorists of place acknowledge human need for attachment to place, but this bond is often stated as a given, without an explication of its origin or attributes. Implementing the concept of placeconnectedness formulated by Lawrence Buell, I analyze the process of bonding with new places described in immigrant life writing, focusing on twentieth-century texts by authors from Russia, the Soviet Union, and Communist bloc countries. Examining the sources through which American imagery was available to East Europeans during the 1900s, I confirm a link between the concepts of the American Dream and of place-connectedness and contend that for immigrants, establishing an attachment to a new place is a process that begins before emigration. The initial stages of this process are imaginative-learning and dreaming about America, visualizing it as an ideal place. These idealized pre-existing images of America mediate immigrants' encounter with the new country and influence their connection to American places.

The American Dream imposes a binary structure on immigration narratives, compelling the authors to contrast the old and the new worlds, the old and the new places. Texts examined in this project demonstrate that the process of claiming a new place as one's own is rife with ambiguities and setbacks. Only by negotiating the rift between the dream and the perceived America can an immigrant adjust to and begin to feel at home in the new place. At the same time, the bond to the home country can never be severed, so that the rejected place, no matter how deficient it might have seemed before emigration, acquires a constituent power in immigrant place-connectedness, serving as a reference point for comparisons and valuations. As transnational individuals, immigrant authors maintain attachment to multiple places - physical, imagined, and remembered. 


\section{Table of Contents}

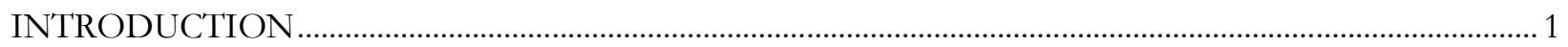

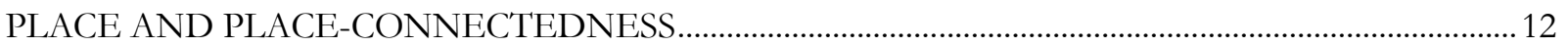

THE AMERICAN DREAM AND AMERICAN EXCEPTIONALISM...........................................................2 29

CHAPTER 1. "THAT ALLURING LAND”: EAST EUROPEAN VISIONS OF AMERICA ...................... 42

EAST EUROPEAN EMIGRATION: A BRIEF OVERVIEW ………………………………………....... 45

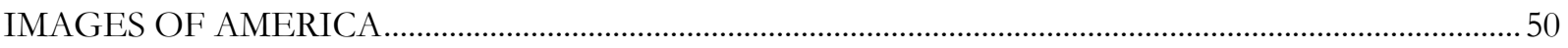

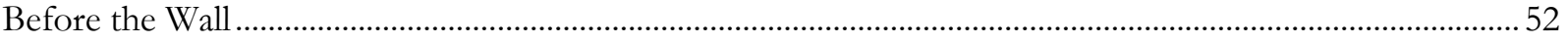

Behind the Wall: Re-interpreting Official Images.............................................................................................. 70

Behind the Wall: Alternative Images............................................................................................................... 85

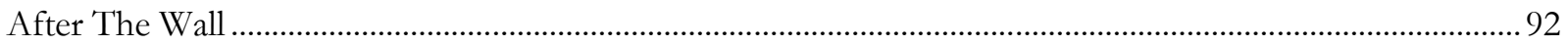

CHAPTER 2. MARY ANTIN TAKES POSSESSION OF AMERICA ………………………………........... 103

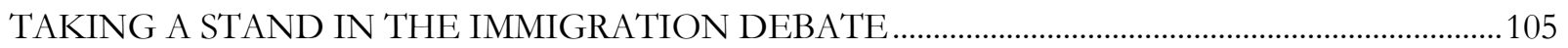

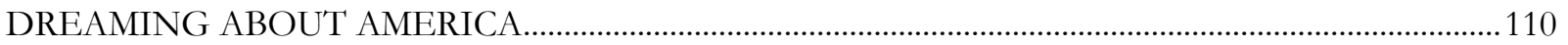

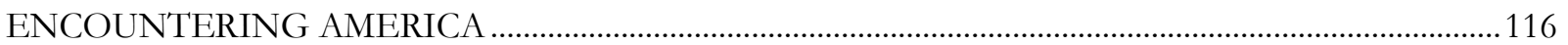

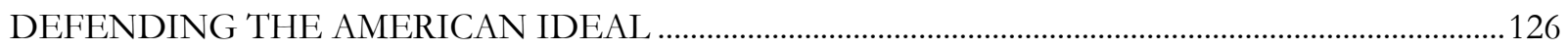

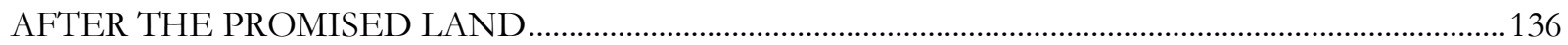

CHAPTER 3. EVA HOFFMAN IN THE LAND OF YEARNING .................................................................150

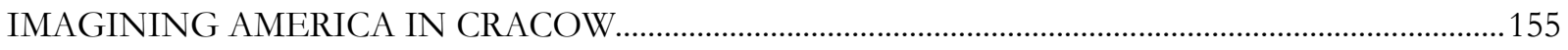

OUT OF PLACE IN NORTH AMERICA ……………………………………....................................... 163

LOOKING FOR A HOME IN THE LANGUAGE ................................................................................... 174

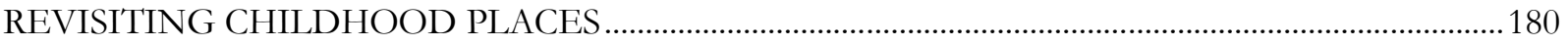

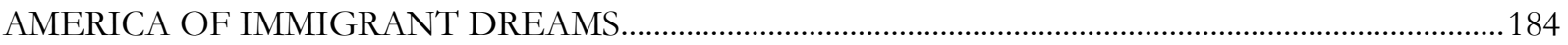

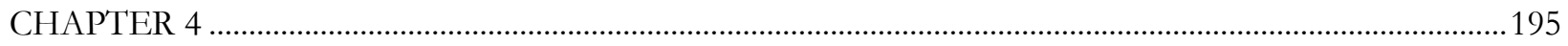

VASILY AKSENOV AND EDWARD LIMONOV IN THE LAND OF FREEDOM..............................195

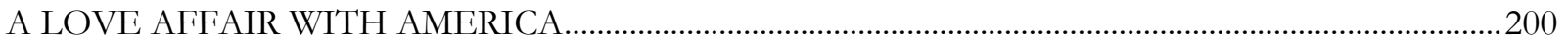

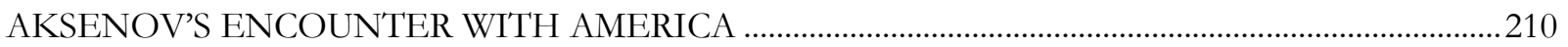

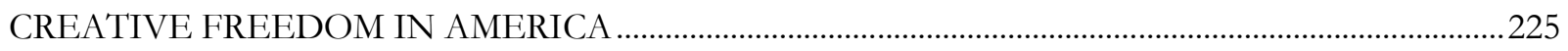

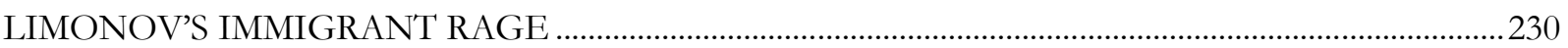

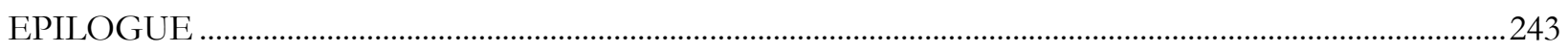

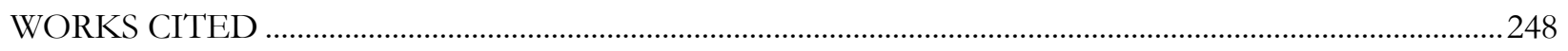

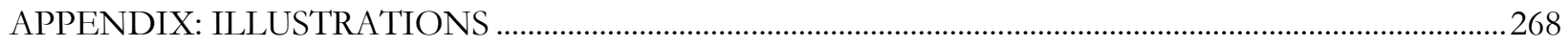




\section{INTRODUCTION}

“Next year-in America!” Such was the dream of Mary Antin's family gathered around their Passover table in Polotzk, Russia (PL 141). Immigrant literature abounds in similar descriptions of what William Boelhower terms "the moment of dream anticipation" (28). Innumerable other families and individuals followed their dreams and left their home countries in search of religious freedom, equality, and justice. They were looking not only for ideals but also for a better place to live, for the mythical "land of Cadillacs and Coca-Cola" (Gurewich 34). This imagined America as well as descriptions of American places in immigrant autobiography are the subject of this dissertation.

My goal is to confirm a link between the concepts of the American Dream and of placeconnectedness. Theorists of place acknowledge human need for attachment to place, but placeconnectedness is often stated as a given, without an explication of its origin or attributes. I contend that for immigrants, establishing an attachment to a new place is a process that begins before emigration. The initial stages of this process are imaginative-learning and dreaming about America, visualizing it as an ideal place - and characteristic of cosmopolitan cultural production that transcends borders and provides an impetus for mobility. Immigrants' encounter with the new country is mediated by this idealized pre-existing image of America, whereas their connection to place can be impeded by unrealistic expectations as to what America should look like or what conditions it should provide to new arrivals. Although some immigrant autobiographers declare immediate bonding to American places, texts examined in this project demonstrate that the process of claiming a new place as one's own is rife with ambiguities and setbacks. Only by negotiating the rift between the dream and the perceived America can an 
immigrant adjust to and begin to feel at home in the new place. At the same time, the bond to the home country can never be severed, so that the rejected place, no matter how deficient it might have seemed before emigration, acquires a constituent power in immigrant place-connectedness, serving as a reference point for comparisons and valuations. The old place can even become a model for organizing the new surroundings so that the latter is transformed by elements of immigrant home culture. As transnational individuals, immigrants maintain attachment to multiple places - physical, imagined, and remembered.

The primary texts examined in this project are written by authors who came to the United States from Eastern Europe, with a selected emphasis on Russophone literature. The provenance of these texts is important for several reasons. First, authors discussed in this dissertation (Vasily Aksenov, Mary Antin, Eva Hoffman, Edward Limonov, and Miriam Potocky-Tripodi) spent their pre-emigration lives in a geo-political space that developed its own version of the American Dream. In the countries ruled by a succession of authoritarian and totalitarian regimes, where an individual did not enjoy the same freedom and respect that was associated with Western democracies, a longing for the ideal America was especially intense. Government restrictions imposed on ordinary human activities - from the laws of tsarist Russia that circumscribed areas of residence and occupation for Antin's Jewish family to the Party directives that limited the choice of subject matter for Aksenov and other Soviet writers—-spread a sense of helplessness and hopelessness among the population. Social and political upheavals that ravaged and reshaped this region during the twentieth century further contributed to the instability of place and to the vulnerability of an individual, forcing many people to look outside their country for a place where they could live their lives with dignity and achieve material prosperity. In East European imagination, America was such a place, an ideal country whose image at the turn of 
the twentieth century was shaped mostly by emigrant letters, advertising effort of emigration agents, and —-for the few literate emigrants—-by literature. For Cold-War-era emigrants, the notion of America was influenced by American and domestic literature, by the conflicting effects of Communist and anti-Communist propagandas, and by such sketchy glimpses of America as occasional Hollywood movies, jazz, and rock and roll music. East European ideal America echoes the domestic myth of American exceptionalism; consequently, tracing the origin of this ideal as well as its expression in immigrant texts illuminates the complex workings and the wide reach of the ideology that designates the United States as the fulfillment of humanity's dream.

Second, it is important to reclaim East European immigrant texts as objects of academic scrutiny because with the fall of the Berlin Wall, the examination of the so-called Second World seems to have lost its urgency. As Katarzyna Marciniak observes, post-Communist space "is now both Western and yet non-Western, a fuzzy in-between" (xv). This definition not just points at the lack of focus on the complex processes that have been going on in Eastern Europe during the last two decades. It also captures the deficiency of Westerners' understanding of the societies that were hidden behind the Iron Curtain and obscured by anti-Communist propaganda. Consequently, the authors considered in this dissertation can shed light on the life led by ordinary citizens in "the empire of evil" and its satellites.

I know that for some scholars and readers a project that puts side by side texts by both Soviet and East European writers might seem problematic because the USSR. dominated its Eastern neighbors for forty years, ruthlessly suppressing any reform movement and any expression of free thought. The Soviet government was responsible for many broken and lost lives. Moreover, most ordinary Soviet citizens were at least indifferent to the plight of East Europeans, while some accepted the propaganda version of the events and supported their 
government's imperial policy wholeheartedly. However, people of the Soviet Union were in many respects as oppressed as the people of Poland and Czechoslovakia; they experienced similar shortages of housing and essential goods as well as restrictions on freedom of thought, expression, and religion. While the Iron Curtain separated the German Democratic Republic from West Germany and Hungary from Austria, another equally fortified barrier isolated the Soviet Union from its western neighbors. In short, Soviet domination of East European countries did not benefit ordinary Soviet people; it did not expand the territory to which they were allowed to travel or their economic opportunities.

In addition, there are similarities in the way communist systems pushed people towards the drastic decision to leave their home country. Soviet intellectuals suffered under the same yoke of ideological restrictions as their East European counterparts. The Party dictate ruled cultural production equally in the Soviet Union, Poland, Czechoslovakia, and other countries, denying writers, artists, and scholars freedom of thought and of creative expression. In all East European countries, anti-American propaganda was at work, creating distorted, cartoonish images of the United States. At the same time, bits and pieces of forbidden Western culture spread throughout the lands. The alternative sources of knowledge about the West were similar in all Communist bloc countries: samizdat and smuggled books, Hollywood movies, jazz and rock music, radio broadcasts by the Voice of America and Radio Liberty/Radio Free Europe. All this information outbalanced the propaganda images and created an idealized picture of a free and prosperous America that welcomes immigrants with open arms.

In spite of the Soviet Union's isolation from the rest of the world, Soviet intelligentsia was keenly aware of the events in Eastern Europe. In the 1960s in particular, cultural influences were mutual and strong. As Vladislav Zubok points out, to intellectuals in Moscow, the Prague 
Spring of 1968 was more important than protest movements in the West, and even people in high official positions, editors and journalists, "rooted for the Czech reformers" (284-5). The suppression of the reformist movement in Czechoslovakia dashed the hopes of intellectual freedom and spurred emigration throughout the Communist bloc. In my study of texts by East European and Soviet authors, I am looking for similarities of existence under Communist governments and for similarities of immigrant conditions in North America.

I open my project with a historical chapter that investigates the complexity of sources for the East European concept of America and traces the evolution of the American Dream from Antin's vision of religious tolerance and material prosperity to Soviet writers' cosmopolitan ideal of intellectual freedom. In subsequent chapters, I examine the selected texts and juxtapose immigrant dream visions with the authors' accounts of their American encounters. In my description of life in the Soviet bloc countries and of immigrant life in America, I rely both on academic sources and on personal interviews with immigrants from East European countries. I also draw on my own experience as a resident of the Soviet Union and as an immigrant in the United States.

I start the discussion of immigrant authors with a text that is often considered the master narrative of immigrant literature-Mary Antin's 1912 autobiography, The Promised Land. Having escaped the discrimination and anti-Semitism of tsarist Russia, Antin claims to have found in America everything an immigrant can hope for: freedom from persecution and boundless opportunities. She asserts that her ambition and hard work are rewarded with prosperity and successful integration; her American Dream is fulfilled. However, a close reading of Antin's book reveals omissions and glosses that, when put together with her letters and the facts of her life, contradict the enthusiastic tone of The Promised Land. In spite of Antin's 
declaration, America does not become an immigrant's new home at the moment of arrival, and the process of domesticizing a new place is more complex than Antin is willing to admit.

Barely concealed fissures in Antin's narrative crack open in the late twentieth-century texts, the authors of which are not compelled to continue Antin's heroic tradition. Instead, they describe less than orderly journeys and less than satisfied expectations. What these authors do have in common with Antin is their escape from an oppressive system and their initial idealization of America. I continue this project by discussing Eva Hoffman and Miriam PotockyTripodi who were, similarly to Antin, children immigrants brought to America by their parents. Like the Antins, these two families were fleeing anti-Semitism and discrimination that limited their economic opportunities in, respectively, Poland and Czechoslovakia. In addition, similarly to Aksenov and Limonov discussed in the last chapter, they were pushed out of their countries by the all-embracing ideological control of the Party. I focus mostly on Hoffman's 1989 autobiography, Lost in Translation: A Life in a New Language, and on the way this text reveals the author's arduous adjustment to American places. Leaving Poland at the age of thirteen, Hoffman reluctantly shared her parents' dream of America's fabulous riches and had to formulate her own motivating vision of social advancement through intellectual accomplishments. In her autobiography, Hoffman presents language as a venue and mode of assimilation, admitting her ambivalent attitude to American places. I include Potocky-Tripodi's short memoir, Where is My Home?: A Refugee Journey (published in 2000), as an additional example of the complex relationships immigrant children maintain with their native places.

The last two texts examined in this dissertation (Vasily Aksenov's 1985 In Search of Melancholy Baby and Edward Limonov's 1978 It's Me, Eddie) were written and published in Russian and also issued in the English translation. Thus, these books address two audiences and, 
for their Russian readers, continue an over-a-century-old tradition of writing about America and of measuring it against the immigrant's (or the traveler's) mental image and expectations. For these adult immigrants who were inspired each by his own American Dream, connection to American places proved to be as elusive as for immigrant children discussed previously. Aksenov and Limonov shared the vision of America common to many Soviet and East European intellectuals of the Cold-War era who, during these decades of informational and ideological isolation, imagined America as a place of intellectual and creative freedom, a society where writers, poets, and artists occupy an influential position. Just breaking out of the confined Soviet space seemed enough for becoming part of a cosmopolitan Western culture, having one's books published, and one's name celebrated, hence the disappointment on discovering in America a commercialized, competitive literary scene and a seeming indifference to high culture. Whereas Aksenov was able to secure a foothold in American letters and academe, Limonov spent the first few immigrant years in obscurity — a difference reflected in the tones of their books and in their responses to American places, in Aksenov's emplacement and Limonov's alienation from the host culture and his surroundings.

The chronology of the discussed texts demands some explanation: what is the rationale for the leap from 1912 (the publication of Antin's The Promised Land) to the 1970s-1980s when the rest of these texts appear? I exclude the intervening decades from this project because the period of less than forty years, 1914-1950, condenses for East Europeans a series of catastrophic events - two world wars, genocides, revolutions, civil strife and civil wars connected with Communist takeovers - all of which engendered mass suffering and dislocation on an unprecedented scale. Emigrant autobiographies coming out of this tumultuous time differ significantly from those written during previous and later periods: the former focus on the 
forcefulness of the displacement and on the traumatic loss of home (and often of family) rather than on dreams of a better life. Although the threat of violence always loomed close by (both for Jews in the Pale of Settlement in Antin's time and for citizens of Soviet bloc countries during the Cold-War decades), these were periods of relative peace and stability. Emigration was influenced not only by the push factors (anti-Semitism, discrimination, or ideological restrictions) but also by the pull of the American Dream, when individuals and families had at least a semblance of choice in whether to stay or to leave. ${ }^{1}$ Moreover, the selected authors' significant focus on description of places - both in their native countries and in North Americaoffers rich material for the examination of the process by which immigrants establish placeconnectedness.

As migrants, all authors discussed in this dissertation are involved in transnational practices. Donald Pease calls the term transnational "a promiscuous signifier" that often is made to represent incompatible claims. He quotes, among other interpretations, a dictionary definition of the term as "someone operating in several countries" (Introduction 4-5), which can be applied to political and economic entities (such as transnational NGOs or corporations) or highly mobile individuals. Although voluntary mobility across borders has been traditionally attributed to social and cultural elites, late-twentieth-century data contest this designation. As Nikos Papastergiadis argues, contemporary global patterns of migration include vast multi-directional movements of people (7) with a high rate of return (44). In contrast with one-directional (East to West or South to North) flows of the previous eras, Papastergiadis calls these complex patterns turbulence (7), urging us to think of migration in terms of "flux and flow, rather than fixing solely on the causes or consequences of single trajectories" (35). Moreover, Papastergiadis warns against making a simple connection between migration and social class (35), noting, for example, "complex and 
dynamic strategies of mobility" among labor migrants (45). However, within these patterns, there are still migrants—immigrants—who make one drastic move from their home country to a new place without a possibility of return. Due to the elasticity of the term transnational, it can be applied to immigrants. In one of Pease's definition, transnational is "a volatile transfer point that inhabits things, people, and places with surplus connectivities that dismantle their sense of a coherent, bounding identity" (Introduction 4). Even remaining stationary in their new location, immigrants sustain connections with their home places, and their new identities are contingent upon home cultures.

Although most immigrant authors represent just two cultures and often structure their texts as binary oppositions between the old and the new place, they present a picture of a hybrid culture and hybrid space resulting from transnational connectivities. Several scholars have commented on the binary roots of immigrant texts as well as on their potential to subvert the ostensible duality of immigration. Marciniak refers to immigrant authors as "bicultural" and to their texts as featuring "binational characters who transgress the boundaries of established nationhood by moving across national borders, languages, cultures, and competing ideologies" (59). These transgressions also question national and cultural boundaries, allowing the emergence of new hybrid identities. Boelhower describes immigrant autobiographies as organizing "two cultural systems, a culture of the present and the future and a culture of memory into a single model" (29), resulting in "a new birth" of the protagonist-narrator that is accomplished in "a doubling, not an erasing process" (49). In other words, Americanization of an immigrant implies acquisition of new cultural habits without the elimination of the previously accumulated cultural baggage. Consequently, becoming a native is not possible since the 
persistence of the original culture turns naturalizing into an asymptotic process. What is possible is the commitment to multiple places and to a cosmopolitan conception of culture.

Similarly to transnational, the word cosmopolitan can refer to individuals, places, and cultural phenomena. As an older term, it is encumbered with negative connotations and has been much contested in the scholarship of the last decades. The controversy around cosmopolitanism results in no small part from its imprecision: what exactly does "a citizen of the world" mean? In the context of postcolonial studies, Inderpal Grewal notes that the key ideas traditionally associated with cosmopolitanism - "the liberal subject as a possessor of rights and the subject of international trade"-were formerly assumed to belong only to Europeans but in the late twentieth century spread out "among formerly colonized and non-European Others through relations of power with the West and histories of colonialism" (42). This means that cosmopolitan elites are no longer exclusively Western, but the shift of economic and trade power to centers located in other parts of the world does not eliminate class distinctions that seem to be inherent in the idea of cosmopolitanism. In relation to immigrants, Marciniak differentiates between cosmopolitan and alien, both of which "refer to a transnational positioning" but have very different "codings and cultural undertones." Marciniak argues that alien "suggests a space of inferiority and unwanted otherness [...whereas cosmopolitan] exudes an aura of sophistication and elegance, and is more readily linked with a desirable economic and racial position" (24). Marciniak's distinction is based on the premise of citizenship and legitimacy, but in cultural terms, cosmopolitan and alien are not mutually exclusive. A migrant can identify himself or herself as belonging to a cosmopolitan culture and still be seen as an alien by the native population of his or her new country. 
The cultural aspect of cosmopolitanism — that is, the existence of one human culture and literature - has been criticized for its elitism and Eurocentrism as well as for its connection to celebrity authors whose writing, as Caren Kaplan suggests, "can be appropriated for hegemonic uses to manage diversity in the context of globalization mainly on the basis of social and economic class affiliations" $(124) .{ }^{2}$ Despite the consistent criticism of cosmopolitanism, it has not been discarded as a means of identification and analysis. In fact, there appeared in recent years an opposite tendency — to defend and re-define the term. Grewal, Marciniak, Kaplan, and other scholars propose a rigorous historicized approach to cosmopolitanism, with "a watchfulness about specificities of racial, gender, and ethnic formations" (Marciniak 24). In an attempt to "rescue" cosmopolitanism (xiv), Kwame Anthony Appiah identifies in it two strands of ideas:

One is the idea that we have obligations to others, obligations that stretch beyond those to whom we are related by the ties of kith and kind, or even the more formal ties of shared citizenship. The other is that we take seriously the value not just of human life but of particular human lives, which means taking an interest in the practices and beliefs that lend them significance. (xv) Appiah's definition might seem utopian, but it explains the continuing appeal of and need for cosmopolitanism in today's world. Dissemination of these ethical ideals and their elevation to the operational principles of the global community gives hope for solving problems arising, for example, from nationalisms and asymmetrical economic development. ${ }^{3}$

Cosmopolitanism does not have to be always connected to mobility. If, as Grewal argues, cosmopolitanism depends on "participation within various discourses of the global, national, and international that moved across transnational connectivities and enabled subjects to cross borders 
or claim to transcend them" (38), then both parts of Appiah's formulation can refer to stationary individuals who can be located anywhere in the world and still be cosmopolitans and participate in what Salman Rushdie calls "cross-pollination of cultures" (20). In the absence of travel opportunities, cosmopolitanism can be a state of mind, and the desire to penetrate another culture can be realized on an intellectual level. Such phenomenon occurred, for example, in the Soviet Union in the 1960s and 1970s, when Soviet intellectuals accumulated a wealth of cultural artifacts (books, records, posters) smuggled from Britain or the United States and learned English just to understand the lyrics of jazz and rock songs as well as to read English books in the original. They also incorporated their knowledge of the anglophone cultures into their own creative endeavors, emulating Western music and literary styles. Although a lack of direct contact with the studied culture breeds a lot of misconceptions, the cross-pollination can work by proxy in relative isolation. Mobility can be the result of cosmopolitan familiarity with the world outside one's home country. Thus, before emigrants leave their countries, they transcend the borders by the very act of imagining a different place. Even if emigrant dreams are based on limited and misleading information — as is the case of the authors discussed in this project—-they are the force that induces the radical change of place.

\section{PLACE AND PLACE-CONNECTEDNESS}

Place is one of the most fundamental, yet most complex elements of human existence. First of all, nothing can exist without or outside of physical place. As J. E. Malpas claims, place is primary both to human existence and "to the construction of meaning and society" (qtd. in Cresswell 32). Lawrence Buell notes that the very importance of place presents difficulties for analysis and conceptualizing because place is often "taken for granted in lived experience" (61). Moreover, as most researchers agree, place is more than just its material features: it includes also subjective and social dimensions that make it meaningful. Summarizing several viewpoints on 
the difference between place and space, Tim Cresswell notes the concreteness and materiality of place and defines places as "spaces which people have made meaningful" (7). The meaning humans attribute to place is not limited to personal feelings and connections; as Cresswell observes, place is "space invested with meaning in the context of power," that is, as part of social relations and hierarchies within and among the groups of people that occupy this place (12). The material and the social aspects of place are, of course, interconnected: humans base their construction of meaning on the sensory perception of places; in turn, cultural precepts determine and color perception. Therefore, our understanding of place should be based, as Cresswell puts it, on "a rich and complicated interplay of people and the environment" (11). Immigrants, who purposefully change their environment, present a particularly rich opportunity for case study.

The reciprocity of perception and culture was first noted by Yi-Fu Tuan. He asserts that "[p]erception is both the response of our senses to external stimuli and purposeful activity in which certain phenomena are clearly registered while others recede into the shade or are blocked out" (4). According to Tuan, such selective response to environment is rooted in the cultural stance, or attitude developed as a result of experience. Humans conceptualize their experience into a world view, or a structured system of beliefs, that is partly personal and partly social (4) and is based, in part, on the physical environment. Tuan also notes that in the study of place we can never "distinguish sharply between cultural factors and the role of physical environment. The concept 'culture' and 'environment' overlap as do concepts 'man' and 'nature'” (59). Moreover, in the question of primacy of the physical place or its cultural meaning, Tuan does not give precedence to either. Environment does not determine the cultural images of place; rather, it "provides sensory stimuli, which as perceived images lend shape to our joys and ideal." On the other hand, the reason we choose to attend some of the "potentially infinite" sensory stimuli and 
ignore others is "an accident of individual temperament, purpose, and of the cultural forces at work at a particular time" (113). In other words, geography is not destiny, and similar physical environments have been hosts to widely different cultures.

In the years after Tuan's seminal book was published, many researchers emphasized the social aspect of place, sometimes minimizing the significance of its physical characteristics. Linda McDowell observes that place is now "defined by socio-spatial relations that intersect there and give [it] its distinct character." As a result, place becomes relational whereas boundaries between places are seen as fluid (4). In McDowell's words, scholars now view place not as a "three-tier cake plate which maintains special separation" but as a double helix or the Möbius strip (5). At the same time, McDowell warns against being "carried away by the fluidity of this new conceptualization and representation of relational place, as customs and institutional structures clearly persist through time and 'set' places in time and space as it were" (5). The relativistic approach can obscure the fact that physical places and boundaries between them continue to cause bitter conflicts and bloody wars. Even in peaceful parts of the world, most people, as McDowell observes, "live spatially restricted, geographically bounded lives, in a home, in a neighborhood, in a city, in a workplace, all of which are within a nation-state" (29). On the other hand, forced or even voluntary displacements often rupture the fabric of life, bringing about a traumatic loss.

It is because human need for place is so fundamental that we should examine carefully the experience of people who migrate from one place to another, challenging what Liisa Malkki calls "fixed, bounded and rooted conceptions of culture and identity" (qtd. in Cresswell 110). In all cultures, there seems to be a constant pull between two tendencies: one is to construct and reinforce the boundaries of place; the other one is to dissolve them. Immigrants are caught in the 
middle: they violate the existing boundaries of settlement and identity; they are often perceived by the natives as a threat to "their" place. On the other hand, the only way for immigrants to survive is to become invested and rooted in a place, to become sedentary, to construct their own boundaries that would secure their place and exclude others.

Both the material and the social dimensions of place play a significant role in immigrant experience. First, it is the materiality and the physical characteristics of place that meet the eyes of fresh immigrants and that they describe in their texts. They are still outsiders to the host society; consequently, their evaluation of the environment is that of visitors, which is, according to Tuan, "essentially aesthetic." They judge their new place "by appearance, by some formal canon of beauty" (64). Tuan contrasts this view with that of a native who "has a complex attitude derived from his immersion in the totality of his environment" (63). After living some time in a place, a person becomes "selective, turning a blind eye" to aesthetically unpleasant features of the place that shock a visitor or a new arrival (65). Immigrants start with being outsiders and being "hit" by the visual elements of their new places. Nevertheless, the process of adjusting to an unfamiliar physical environment — to its climate and terrain, to its animal and plant lifestarts immediately because it is a crucial step to surviving and ultimately succeeding in the new life. Over time immigrants shift closer to the native's perspective and develop a more complex attitude towards place, maintaining simultaneous connection to the new and the old places.

Unlike the physical characteristics of place, the social hierarchies and networks that intersect in and around immigrant places are not as easy to discern. Yet, understanding the social implications of places, the conventions of behavior, and the patterns of movement from place to place are also of utmost importance for immigrants. For example, Aihwa Ong adopts Pierre Bourdieu's concept of symbolic capital, or "practices that attest to social distinction of subjects," 
and adapts it to the "cross-cultural, transnational arena" (89) of the Pacific Rim migrations and business transactions. Ong asserts that in order to succeed in the world dominated by Euro Americans, immigrants from Asia need to accumulate the kinds of symbolic capital that would be recognized "not only in the country of origin, but also in the country of destination" (89), listing Western education, property ownership, green cards, and philanthropy as the necessary accomplishments. Although Ong is discussing mostly wealthy entrepreneurs, the concept of cultural capital is applicable to immigrants of all social levels. Learning how to buy a subway ticket or to prepare for a job interview can become their first investment.

There is no doubt that social dimensions of place, such as class, gender, media, production, power, are important, and so are physical characteristics of place and its materiality. Furthermore, place has another aspect, epistemological. As Cresswell declares, place is "a way of seeing, knowing and understanding the world" (11). People use place as a lens through which they observe and define one another, their relationships and experiences, which is why place is a significant element of literature. Most literary texts provide at least a minimal setting for the action and some description of the characters' physical environment. Leonard Lutwack traces the history of place in literature from the unity of place in drama to place as a subject of romantic poetry (14) to place as a specific environment that forms the character in a novel (17). Lutwack brings up examples from The Iliad to show that place and the symbolism of place have always been important in literature; he also observes that "not until the eighteenth century did fiction begin to develop environment as a matrix in which character is formed" (19). Some texts, such as Thomas Hardy's novels, belong to a category that Lutwack calls "place-saturated fiction" where place is not only prominent but also formative (24). Thus, realistic writing is "philosophically committed to the faithful rendering of actual places in order to qualify as realism"; place is also 
significant in regionalism that is "bound by definition to do justice to the geographical particularities of a specific area" (29). Place becomes central in naturalistic writing where "the techniques of detailed and cumulative descriptions of environment $[\ldots]$ reveal the horrors of town and city, farm and factory $[\ldots]$ reversing the romantic feeling of endearment to one of revulsion" (11). Moreover, naturalism often establishes deterministic relationship between place (almost always a negative place) and character. Significantly, one of the most influential naturalistic texts, Upton Sinclair's The Jungle, focuses on immigrant experience in the cloacae of modern metropolis where character is destroyed and lives crushed.

Reflecting the changing concept of place in geography and sociology, the fortunes of place in literary studies have also fluctuated significantly since the early 1900s. For example, in what seems to be a reaction to environmental determinism, Wesley A. Kort has argued that prominence of place in a literary text can result in the diminishing of other means of characterization. He identifies four kinds of narrative language: of character, of action and event, of the teller's interests or attitudes, and of place and environment (14). Kort claims that these languages compete with one another in a narrative. When spatial language becomes dominant, it flattens the plot and the characters, leaving them fewer choices than they would have otherwise, and "forces" the material on the teller, changing his or her role from that of "moral evaluation" to "one of uncertainty and obsession" (17). Kort's assessment might be applicable to the early and late modernism texts he is discussing (from Thomas Hardy and Joseph Conrad to William Golding and Muriel Spark), but it seems to have less relevance in the case of postmodern authors who often refrain both from saturating their fiction with realistic description of places and from moral evaluation of the characters. Their texts also show a more complex relation between place and character than a one-way determinism. ${ }^{4}$ 
Some scholars have disputed attempts to localize literature in regionalism studies.

Roberto M. Dainotto asserts that “by 'getting back to place' we have lost a historical perspective" and that "place [...] is fundamentally a negation of history" (2). Specifically, Dainotto responds to the trend of regionalism that "depicts itself as some kind of liberation front busy to set marginal and vernacular cultures free from an all-equalizing nation" (5). Contrary to such claims, regionalism, in Dainotto's opinion, is analogous to nationalism. Like the latter, "in order to justify itself, regionalism has to tend toward a sense of ethnic and cultural purity without which it could not even postulate a 'region"' (22). This assessment of place echoes the worries of some geographers who, as Cresswell reports, refer to "seeing the world through the lens of place [as leading] to reactionary and exclusionary xenophobia, racism and bigotry" (11) and warn against an essentialist construction of place (26). Despite the validity of these concerns, deployment of place as a category of analysis can be productive rather than restrictive. In particular, immigrant literature, whenever it offers a fresh look at familiar places and demonstrates the transformative effect of migrant populations on place, might be just the tool needed to counter reactionary tendencies in place studies.

Not all scholars agree with vilification of place and of the role it plays in literary texts. Thus, Buell praises the power of "environmental imagination" in literature (56). Although he admits that "place attachment can $[\ldots]$ become pathological: can abet possessiveness, ethnocentrism, xenophobia" (76), Buell contends that regionalism "affirm[s] place against placeeroding historical forces" (58) and that its variations, such as bioregionalism and reinhabitation, allows displaced and "ecologically illiterate" people to become engaged with their environment (84). Both regionalism and objections to it demonstrate that place in literature is as much a battle ground as places are in the physical world. Moreover, if literature, as Lutwack argues, is 
instrumental in "attaching values to places" (35), the two kinds of battles are interdependent. Since one of the war-cries in the political debate on immigration is an allegation that immigrants defile — both literally and figuratively — the places they move into, a study of place in immigrant literature can furnish an outlet to alternative and often unheeded voices.

Whether the causes are demographic, economic, or environmental, deterioration of place is a grave concern in today's world and in contemporary literature. In addition to toxic and apocalyptic discourse that addresses the declining physical characteristics of place, literary texts often convey a sense of confusion caused by the instability of place. Even with the rise of regionalism and other place-based writing, twentieth-century literature abounds in texts that convey, as Lutwack puts it, "a sense of place-loss and a sense of placelessness." Lutwack considers this trend to be an inheritance of a century of naturalistic writing (11) that had been documenting the deterioration of "once-cherished" places and the appearance of new "questionable places [...] created by new social and economic forces" (182). Raymond Williams, on the other hand, sees this nostalgic pining for and sentimentalizing of lost places as a much older human habit that can be traced to the biblical myth of lost Eden. In Williams's terms, it is "an escalator effect" that makes the golden age or "an unlocalized Old England" constantly recede into the past (9-12). A sense of placelessness can result not only from the continuous transformation of places but also from the movement of people away from familiar places. Immigrant literature, in particular, deals with the loss of place and the process of becoming rooted in a new location. Literary accounts of immigrant experience are often structured around the contrast between the place of origin and the destination, but the emotional valence of each side is not pre-determined. Some immigrant authors, for example Antin, reject the country and the town from which they have come and, contrary to their own observations, present America as 
an ideal place. However, at close examination the dichotomy of such texts breaks up, revealing a complex interplay between past and present places. Late twentieth-century authors are more frank in portraying their conflicting feelings towards place and about their struggle to accept their new home.

It is necessary for immigrants to invest place with personal meaning and to develop some sort of ties to their environment—what scholars call topophilia (Tuan 4) or place-connectedness (Buell 64). In this dissertation, I choose to lean on place-connectedness for several reasons. Tuan's book on topophilia is a foundational text in this field. However, his definition of topophilia as of an "affective bond between people and place or setting" (4) lacks precision. First, although the definition itself implies any kind of emotion and the author does concede that topophilic ties can "differ greatly in intensity, subtlety, and mode of expression" (93), his use of philia gives the word the connotation of a loving and positive connection to place. Tuan's definition does not account for the complexity of human feelings, such as can be observed, for example, among immigrants. Their bonds to places they occupy in the new country are often ambivalent: one can be attached to a place that provides shelter and means of survival without necessarily loving it. Furthermore, Tuan offers only one model of topophilia that is based on the egocentric and ethnocentric traits of human perception - a tendency "to perceive the world with 'self' as a center." Consequently, the affective ties humans have to a place or setting are seen as a series of concentric circles with diminishing intensity of bonding (30-31). This model does not cover cases of immigrants who can be more attached to the places they have left than to places they inhabit. Buell further develops both Tuan's concept and his model of topophilia.

First, instead of topophilia, Buell uses place-connectedness, a term that does not imply any kind of emotion. Consequently, it can be used to describe a whole range of emotions, from 
philia to phobia or odium. Moreover, Buell complicates Tuan's concept by suggesting several additional models. The concentric circles of affiliation are still a valid, even "the most familiar way of imagining place-connectedness," but they are complemented by four more models, all of which are important for my project of analyzing immigrants' connection to place. Thus, "a scattergram or archipelago of locales, some quite remote from each other" is applicable not only to the "patchwork" of ordinary middle-class life (64-65), but also to immigrant experience and immigrant transnational practices. Similarly, Buell's fourth model of place-connectedness, "an accumulation or composite of all the places that have been significant to a person $[\ldots]$ over time" (69), reflects the situation of an immigrant who arrives in a new country with mental baggage shaped by physical characteristics and social entanglements of a different place.

Moreover, any immigrant contributes to what Buell lists as a third consideration-the instability of place that is "continually shaped and reshaped by forces both inside and outside" (67). Immigrants are one of these formative forces that reshape places: an influx of foreigners changes not only the demographics of a place but also its physical characteristics and social dynamic. It affects the lives of native residents and often evokes their hostile reaction. Not everybody is happy to see in their neighborhood ethnic stores and signs in strange script, or to hear foreign languages spoken. Immigrants are a vehicle of these changes. Finally, Buell's fifth dimension, "connectedness with fictive or virtual places" (71), is especially important for my project. Buell quotes sociologist Anthony Smith who said that a "land of dreams is far more important than actual territory" (72). Applied to immigrants, this claim certainly rings true: we can safely say that a land of dreams is important enough to make people leave their native countries and pursue the imagined America of their dreams. Buell also draws a distinction between the unseen actual and the imagined utopian places, including in the latter not only such 
unearthly realms as the traditional Christian heaven but also "a home, which centuries of writers have tried to describe and believers to visualize" (73). Both the unseen actual America and the imagined utopian America are a strong motive for immigrants and a significant factor in shaping their new lives in the New World.

Most immigrants come to North America with an intention to settle and make the new place their home. Therefore, it is appropriate to examine the meaning of home, a concept that has changed drastically in recent decades. According to Cresswell, humanistic geography conceptualizes home "as an exemplary kind of place where people feel a sense of attachment and rootedness $[\ldots$ as $]$ a center of meaning and a field of care" (25). Contesting what they consider a masculine view of home, early feminist scholars argued that home is "a cage, a trap, a prison, and, for some women, a site of fear and abuse" (McDowell 88). Recently, scholars began to see this stance as white middle-class and, therefore, narrow. Thus, Elizabeth Roberts asserts that gender relations in working-class households historically differ from those of middle- and upperclass families because limited material resources often result in stronger need for cooperation between genders rather than in antagonism (qtd. in McDowell 79). A similar point of view is expressed by black feminist scholars and writers for whom home "has long been one of the only places of escape from the oppressive relations of first slavery and later racist society" (McDowell 89). Many immigrants also come from cultures where home and family were traditional bastions of support in the hostile world. For example, East European Jews relied on extended families and informal networks for survival; dissidents in Communist countries cherished the privacy and security of their homes where they could share their thoughts with family members and trusted friends. All these attitudes toward place can be applied to immigrant families: in the process of acculturation they become rooted in and attached to a place; feeling isolated from unfamiliar, 
often hostile host culture, they pull resources and cooperate; they can also become entrapped in their own narrow circle and their community that holds on to the Old Country values and traditions. Thus, an immigrant home has a potential of being a safe haven, a support base, and a prison, yet it is always a significant factor in the process of integration into the host society.

A new place becomes a home not at the moment of settlement but by degrees; correspondingly, the old place does not stop being home at the moment of departure. As Myria Georgiou argues:

Home...in the case of the diaspora has a more complex meaning than in the case of other populations. There is a home, which equals the domestic and the familial, and there is a symbolic, imagined home that might be mythical, occupied, unreachable and/or connected to memories of exile and nostalgia. Images and sounds shared with other members of the home that bring closer together past and present, reconcile the inconsistencies between the lived and the imagined home. (6)

Thus, the meaning of a place occupied by immigrants is constructed out of an array of factors: not only of the physical and social characteristics of the place apparent to "native" residents, but also of the memories of their place of origin as well as of dream images that preceded the move to the new country. In many cases, immigrants arrive in a place that has been shaped by several generations of their compatriots to resemble the place they had left behind. Settling down in such diasporic communities can be both a boon and a bane.

For most immigrants, choice of locales in their new country is ruled by historical patterns of settlement, but these patterns have changed during the last century. As Alejandro Portes and Rubén G. Rumbaut note, before World War I, the majority of immigrants consisted of "ruralbound groups coming to settle empty lands or work as farm laborers," but since then migration 
has become "a network-driven process" $(55,40)$. Consequently, new arrivals tend to follow the well-beaten paths that lead them to Chinatown, "Little Havana," "Little Saigon," or "Little Odessa." Portes and Rumbaut add that during the twentieth century, the majority of immigrants ended up in just a handful of major metropolitan areas of the country: "the northeastern coastal corridor from Washington, D.C., through Philadelphia, New York City, and Boston; [...] Chicago, Detroit, Houston, Dallas-Fort Worth, Phoenix, Atlanta, Minneapolis-St. Paul, and Seattle" (43). In such parts of the country as California, southern Florida, and the whole length of the Mexican border, high concentration of immigrants spills out of urban centers (Los Angeles, San Jose, and Miami) into the rural areas. The tendency to settle within or in close proximity to existing ethnic communities is especially pronounced for manual labor migrants who depend on the network of their compatriots for jobs; reciprocally, immigrant entrepreneurs gravitate to the places where ethnic labor is available. The two categories of migrants who "tend to be more dispersed throughout the country" are professionals as well as refugees and asylum seekers. The former can settle anywhere they want because they can function independently within American communities whereas for the latter a place of residence is often assigned by government officials (Portes and Rumbault 41). As a result of these patterns, scholars observe both high concentration of immigrants in a few areas and their wide diffusion throughout the country. This trend continues into the twenty-first century. Portes and Rumbaut quote demographic data for 2002, when "less than 5 percent of legal immigrants went to live in nonurban areas, and 40 percent settled in just 10 metropolitan locations" (43). The reasons for choosing traditional places of settlement are numerous and complex.

The most important function of an ethnic community is to provide its residents with jobs. Portes and Rumbault compare fresh immigrants to youngsters: they enter the job market "at the 
bottom of their respective occupational ladders" even if they are qualified for better positions. Poor language skills and lack of references force not only manual workers but also professionals to "accept less desirable entry jobs within their professions and even outside them" (58).

Beginning entrepreneurs usually start (and some remain) operating within their ethnic community where they, on the one hand, can have a reliable source of labor and, on the other hand, know the needs of their customers.

Apart from providing job opportunities, ethnic communities function as a cultural and linguistic buffer between immigrants and the host country. As Berry R. Chiswick and Paul W. Miller note, ethnic enclaves are areas of "linguistic concentration" (83) where new-comers can survive without the mastery or even elementary knowledge of the host language. Choosing to settle and work within one's own ethnic group serves as "a mechanism for sheltering oneself from, or mitigating the adverse labor market consequences of, limited destination-language proficiency" (87). At the same time, early arrivals use their mastery of the host language to ensure communication between the ethnic community and the host culture; they also share their "location-specific human capital" (83), thus smoothing the adjustment process for the newcomers. Moreover, as Portes and Rumbaut note, without the protection of a strong ethnic community, children of immigrants face the danger of downward assimilation, or "joining the most disadvantaged minorities at the bottom of society" (263). Thus, both the immersion into their native language and the network of support provide immigrants who settle in ethnic enclaves with a sense of belonging.

In addition, such locations satisfy immigrants' gastronomic, visual, and social nostalgia. To explain the attractiveness of ethnic enclaves, Chiswick and Miller introduce the concept of "ethnic goods" that includes not only, obviously, food and clothing but also services—religious 
rituals, ethnic holidays, mother-tongue media, and even opportunities for meeting an eligible partner (83-88). Diasporic communities become a cornucopia of highly desired products, especially those that in the old country were considered the paraphernalia of privileged classes and that figured prominently in the dreams about plentiful and free America. Thus, the inventory of international grocery stores in the Brighton Beach area of Brooklyn, one of the largest Russian-speaking communities in the United States, usually feature such delicacies as caviar, three dozen varieties of hard salami, over forty brands of tea, dairy and bread products unheard of elsewhere in America, as well as traditional Russian herbal remedies and personal care products. The names of Brighton Beach businesses can be unmistakably traced to the former Soviet Union: restaurants (Tatiana, Primorsky, Baku), bookstores (St. Petersburg, White Nights, Black Sea), and specialty shops (Misha of Siberia Furs and Leather; Olga's Lingerie and Sportswear). The life of Russian-language communities is covered in numerous (over thirty in the United States) newspapers. The oldest of the lot is Novoye Russkoye Slovo (The New Russian Word) founded in 1910 in New York. Among the recently started newspapers one can find Arizonskiye Novosti (Arizona News), Zerkalo (Mirror), and Novaya Zhizn (New Life), providing news coverage, entertainment, and advice for Russian communities of, respectively, Tempe, Arizona, Denver, Colorado, and Reaverton, Oregon ("Russian America"). The diffusion of immigrants throughout the country has created new pockets of language concentration with population numerous enough to support such a costly enterprise as an ethnic newspaper.

With the spread of new computer-based media, a lot of services provided by diasporic communities are also available through the Internet, and immigrants living outside of metropolitan areas can access newspapers and order books and groceries online. The Internet and more traditional ethnic media (television and radio), in Georgiou's words, "saturate diasporic 
space" (12) and "provide repertoires for the construction of new individual and communal identities" (7). Nevertheless, electronic communications cannot completely replace the face-toface interaction of ethnic enclaves. Georgiou argues that diasporic communities and identities are sustained in public spaces, such as cafés and community centers (105). Moreover, media consumption itself is a "social act [...] grounded in social contexts" (72). Watching sporting event or news in company with speakers of one's native language allows an immigrant a respite from the stressful interaction with the host linguistic environment.

Thus, immigrant home (and a diasporic community) can be a support base that allows newcomers to survive and gradually adjust to their new life and new culture. On the other hand, both an individual's home and the ethnic community to which an immigrant belongs can become a stifling and confining place out of which there is no escape into a wider world of host culture. For example, ethnic enclaves often breed tightly knit criminal groups that use legitimate retail establishments as fronts for illegal activities. Timothy J. Meagher observes that, although the image of an Italian Mafioso is still persistent in American pop culture, Italian crime organizations have long been in decline and are now superseded by "younger and hungrier Latino, Russian, and Asian immigrants" (189). Ethnic criminal groups do provide support to their own - at a price. Joining such a group might ensure immediate survival of a new immigrant but will become an obstacle to his or her integration into the host society in the future. Furthermore, even without criminal association, immigrants who are dependent on an ethnic enclave for support can lose motivation to learn more about the host culture. Most importantly, learning a new language at an adult age requires a lot of effort and dedication; it is all but impossible without a strong incentive or a dire need to become competitive on the "native" job market. Stuck in their ethnic enclaves, immigrants can lose the willingness to absorb the new 
culture, thus falling into what Salman Rushdie considers the most dangerous of the elephant traps that await an immigrant-"the adoption of a ghetto mentality" (19). In a conversation with Rushdie, Edward Said gives an example of such insular existence: Palestinians living in a small town in America might keep up with the latest event in the Middle East and not know the name of the mayor of their town or whether the mayor is elected or appointed ("On Palestinian" 174). Such isolation from the mainstream of American life and what Papastergiadis calls "experience of $[\ldots]$ ghettoization" (20) are, in fact, quite common. It is possible, on the one hand, because of the numerous diasporic enclaves spreading out of the metropolitan into semi-rural areas of North America and, on the other hand, because of the communication technology that allows immigrants to maintain contact with the centers of their ethnic culture, thus resisting not only integration into but even any contact with the host culture beyond what is necessary for survival.

Since ethnic communities, these islands of home culture and language, both cuddle and stifle their residents, pushing the delicate balance between place and culture towards more rigid determinism, immigrants learn very quickly that their upward mobility depends on the place they inhabit. Whereas some families choose the protective embrace of their diasporic community, others plunge into the "native" world. They often go out of their way to pay a rent they can barely afford so that they can live in a safe neighborhood and send their children to a good school. Settling in a predominantly native-born area signals both an intention to be independent from former compatriots (as well as of the ghetto mentality) and an attempt to integrate into the host culture. Moreover, it can be the result of a belief that eventual assimilation —an integral part of the American Dream, supported by the master narrative of the "melting pot"-is both desirable and possible, if not for the first-generation immigrants, then at least for their offspring. 


\section{THE AMERICAN DREAM AND AMERICAN EXCEPTIONALISM}

Starting with the first European arrivals and early American texts, the American Dream was essentially an immigrant dream. Whether they were searching just for a way to get rich, as did the first settlers of Virginia, or also for an opportunity to create a utopian religious community, as did the Puritans and the Separatists of New England, first immigrants dreamed of a better place for themselves and their children. The concept of the American Dream has evolved to include also (and for some people primarily) the promise of success and upward mobility for native-born Americans. As Jim Cullen remarks, it "remains a major element of our national identity." Cullen calls the American Dream "a glue" that holds together this nation; it is especially important at the time like ours when

the greatest surge of immigration in our history [...] brings more people to our shore than ever before [and when] we don't always speak the same language. At a time like this, the American Dream becomes a kind of lingua franca, an idiom that everyone-from corporate executives to hip-hop artists - can presumably understand. (6)

At the same time, the American Dream also remains a guiding principle for new generations of immigrants. All major components of the American Dream that Cullen identifies-religious freedom, political freedom, upward mobility, the quest for equality, home ownership, and personal fulfillment — are among the reasons immigrants come to America (8-9). When Cullen considers the United States to be "essentially a creation of the collective imagination," he counts immigrants among the creators because it is the new arrivals who constantly re-create the nation "as a deliberate act of conscious choice." As Cullen notes, the American Dream of the twentyfirst century is still based on the theory that American identity is a matter of "[e]xplicit allegiance, not involuntary inheritance" (6). Thus, the promise of the American Dream is an 
opportunity for every immigrant to become American and to be smoothly integrated into American society.

In addition, the American Dream is more than just an idea of a freedom and success. It is also a set of images of ideal places that immigrants expect to find and inhabit upon their arrival. One can say that a place component of the American Dream was present from the colonial time. Describing the joy of a newcomer to the American continent, J. Hector St. John de Crèvecoeur presents a list of places that meet the eye and fill the new American with pride: "fair cities, substantial villages, extensive fields, an immense country filled with decent houses, good roads, orchards meadows and bridges" (66). This picture of prosperity must have had a special appeal to European readers because of the demographic conditions of the Old World. Oscar Handlin observes that "[t]he immigrant movement started in the peasant heart of Europe" (Uprooted 7) and was fuelled by land hunger. With the increase of population during the eighteenth and nineteenth centuries, the land became "scarce, divided again and again; its price rose steadily whether for purchase or rent, and each rise diminished further the margin left for the peasant's subsistence" (Uprooted 25). Impoverished landless peasants were forced to migrate either to the rapidly developing industrial centers of Europe or to the vast new continent where land was supposed to be easily available.

Apart from being a desirable commodity and a measure of wealth, land also assumed other functions and acquired a higher, symbolic meaning for Americans. According to Cullen, instability of financial institutions in nineteenth-century America made land "a more practical and accessible financial instrument than cash [...and] a medium of exchange" (137) as well as "an avowed instrument of government policy" (138). Cullen argues that for British colonists, more than to their Spanish, French or Dutch counterpart, "a notion of America as a particular 
place" that can "serve as home" became important (138). Moreover, land was also ascribed transformative power. Thus, Crèvecoeur announces that lands procured by immigrants after a few years of labor "confer on them the title of freemen" (69). When Crèvecoeur's promise of abundance was reaffirmed during the early years of the republic, Washington used biblical language when he wrote to Marquis de Lafayette that "anyone [...] who is heavy laden or who wants land to cultivate, may repair thither \& abound as in the Land of promise, with milk and honey" (qtd. in Cullen139). This attitude towards land and specific places persists in American culture where, as Cullen observes, “development of a particular place where a variety of people could transform, acquire, or lose lives" is as significant as accumulation of money (137). The notion of America as a vast tract of free land and the land of the free laid the foundation to the myth of American exceptionalism.

Starting with Crèvecoeur's praise of "the most perfect society now existing in the world" where "there are no princes for whom we toil, starve, and bleed" (67), America has been pictured as the land of equality and of just government. Out of such assumptions, as Pease argues, "Americans have developed the lasting belief in America as the fulfillment of the national ideal to which other nations aspire" (New 7). Pease defines American exceptionalism as clusters of absent (feudal hierarchies, class conflicts, socialist labor party, trade unionism, and divisive ideological passions) and present (a predominant middle class, tolerance for diversity, upward mobility, hospitality toward immigrants, a shared constitutional faith, and liberal individualism). (New 8)

Through "state fantasy work," exceptionalism discourse becomes internalized by Americans, allowing them to view "inherent rifts and contradiction [in the existing order of things] as if they were sources of personal enjoyment rather than pain and resentment" and to justify such 
shameful acts as Jim Crow or Japanese internment camps that obviously contradict the proclaimed values of American democracy (New 4, 6-7). It is clear from Pease's definition that the treatment of immigrants is one of the key components of American exceptionalism.

Constant knocking on America's door keeps reconfirming the myth of perfect America to its inhabitants. The triumphant story of immigrants flocking to American shores to escape oppression and successfully assimilating in the proverbial melting pot has become an integral part of national identity. However, this master narrative subsumes the stories of involuntary migrations as well as of immigrant hardships and disillusionments. As Pease notes:

Immigrant narratives representing the United States as a haven from colonial and political oppression [...] authoriz[ed] the mythology of U.S. exceptionalism. Each such story eclipsed the history of U.S. colonial relations. The myth of the United States as a promised land lacking the history of imperial domination and class oppression which haunted European memory effaced the middle passage narrative of slaves brought to the United States against their will, the stories of migrant laborers the state has newly colonized, and the accounts of migrants who felt their conditions had worsened. ("C.L.R. James"152)

Although there is no shortage of horror stories relating the hardships and failures that await the newcomers, the image of America as a nation of immigrants persists because the effacing mentioned by Pease is not a one-time act but an on-going process of forgetting - what Ali Behdad calls "historical amnesia" (xii). Behdad argues that the "illusory retrospective narrative" of hospitality towards immigrants cannot exist without "ignoring the horrendous disciplining and criminalizing of aliens that is happening to us today" as well as without acknowledging "many historical facts about the nation's past, most importantly that its open-door immigration 
throughout the nineteenth century was motivated not by hospitality but by colonialist will to appropriate land and by capitalist desire for expansion" (8). Behdad demonstrates that hostility and hospitality towards aliens have always coexisted as "competing paradigms of cultural identity in the United States" (16). He uses a concept of "historical forgetting" (3) to explain how “America's 'other"” keeps changing because "every historical epoch demands a new representation of the seditious foreigner" and how each new generation forgets the harsh treatment of immigrants and "the anti-alien sentiments" of their predecessors (11)—even though almost every American family has its own story of the trials their first-generation immigrant ancestors experienced. It is the internalized belief of American exceptionalism that allows the nation and the individual to forget, and it is the erasure of memory that, in turn, reinforces the exceptionalism myth and spreads it beyond American borders.

This idealization of America has always operated outside as well as inside this country, inspiring millions of people to leave their homes in the hope of achieving this ideal. During the decades of mass emigration from Europe, tales of success and prosperity of immigrants have been reaching its distant corners — often through the efforts of emigration agents. If contradicting stories of hardships were also circulating, people still put their faith in the myth of hospitable America. It is possible that the profit-driven motivation of shipping company agents was not immediately clear to prospective emigrants and that the agents' efforts were interpreted as invitations from interested parties in the United States or even from the American government. Thus, another aspect of the American myth-America's need for more people — was reinforced. According to Behdad, the myth of immigrant America as the self-manifestation of national character embodies the symmetrical figures of project and destiny: the narrative consists in believing that 
every generation has embraced and passed on to the next the invariant idea of the United Stated as an asylum for the oppressed, and that the realization of such a project is the inevitable destiny of the nation. (8)

Immigrant and America can also be paired as symmetrical figures: immigrants arriving in the New World are fulfilling not only their but also America's destiny and can expect America to become their Promised Land.

The use of biblical imagery in the American exceptionalism discourse helped Jewish emigrants from Eastern Europe to identify with America's destiny — as the title of Antin's autobiography demonstrates. Werner Sollors observes that since the seventeenth century biblical images have been used to describe the new experiences of American colonists, especially New Englanders who "interpreted their transatlantic voyage as a new exodus, their mission as an errand into the wilderness, and their own role as that of a new chosen people"- thus creating a precedent for further appropriation of the Bible and of the promised-land rhetoric by other ethnic groups. The theme of Exodus as a deliverance from slavery is also prominent in African American writing (Beyond Ethnicity 40-41, 44). At the time of Antin's emigration to America, the language of exceptionalism was used by East European Jews who, according to Alvin H. Rosenfeld and Moshe Davis, saw both America and Palestine as "the land of promise." When the Antins embarked on their journey to America, many of their neighbors were "traveling southward to rebuild Zion in Ottoman Palestine." In the competition between the two destinations, "America, with its aura of limitless opportunity had the clear edge over the poor, arid, ancestral homeland in the Middle East" (114). One might add that the image of America, unlike that of Palestine, was further adorned by the myth of its hospitality. Michael Brown points out that "[e]ven Zionists in America sincerely believed the United States to be "the most glorious 
of countries," and Jews outside the United States often viewed it as "a new Land of Israel" (153). Consequently, tying their destiny with that of America seemed natural to many Jews. For example, the two most influential Jewish intellectuals in Antin's life, Israel Zangwill and Josephine Lazarus, supported mass emigration of East European Jews to America. ${ }^{5}$ In her 1895 book The Spirit of Judaism, written just two years before the World Zionist Organization was created, Lazarus quotes Zangwill's declaration that Russia and America are the two strongholds of the [Jewish] race, and Russia is pouring her streams into America, where they will be made free men and free thinkers. It is in America, then, that the last great battle of Judaism will be fought out; amid the temples of the New World it will make its last struggle to survive. (128-129)

This vision of America as a New Jerusalem, a place where Jews, the original "chosen people" of the Bible, can revitalize and continue their religious tradition, was inspired by and also played into the exceptionalist idea of America's unparalleled religious tolerance and liberal individualism. The latter component of American exceptionalism proved to be particularly alluring to the late-twentieth century emigrants from the Soviet Union and Eastern Europe.

During the decades of the Cold War, as Pease points out, American exceptionalism became further consolidated into a political doctrine that, when a global war on communism was declared, helped to legitimize the country's aggressive foreign policy and the restriction on civil liberties at home (New 25-26). Thus, American citizens acquiesced to the activities of the House Un-American Activities Committee and to the overall atmosphere of suspicion when, according to Edward Pessen,

[t]he Constitution was brushed aside, men and women were branded traitors not for what they had done but for what informers said their words meant, individuals were 
imprisoned, their reputations ruined on the bases of the doctored testimony of admitted liars and perjurers. (458)

Nevertheless, Americans still believed that they lived in an exemplary free country. Moreover, propaganda efforts disseminated the exceptionalism ideas over the world, targeting in particular the population of America's number one foe-the Soviet Union and its satellites. During this time, several government agencies were established to fight the ideological battles of the Cold War: the Central Intelligence Agency (1947), the United States Information Agency (1953), and the United States Agency for International Development (1961). The Voice of America began regular broadcasts in Russian in 1947, soon adding programs in other languages for the Soviet bloc countries. In 1949, Radio Liberty and Radio Free Europe joined the enterprise of projecting an ideal America into the Second World.

Cold-War treatises on ideological persuasion furnish ample evidence for the goals of antiCommunist propaganda - idealization, rather than a truthful depiction of the United States. For example, in 1976, Leo Bogart, a leading American sociologist, published an analysis of a newly declassified 1953 report of the USIA activity. Bogart was responding to a perceived erosion of America's previously "enormous" prestige in the world and to the domestic loss of faith in the "messianic mission with which the country concluded its crusade in World War II" (xvi). His book is an attempt to revive the propaganda premises of the 1950s and to resolve some dilemmas that the propaganda professionals were facing in the post-1960s, post-Vietnam, post-Watergate America. According to Bogart, still valid in the 1970s is the 1953 advice to emphasize the following "positive traits and values":

1. Americans are nice people

2. America is generous and altruistic. U.S. self-interest is enlightened. 
3. America is democratic. Americans believe in freedom of thought and expression. In a democratic United States, all races and creeds live happily together. The United States comes close to being a classless society. Americans don't consider it beneath a man's dignity to work with his hands.

4. Americans believe in freedom for other people. The government and people have never swallowed heavy-handed colonial policies. The U.S. is not an imperialist power.

The list of glosses goes on to describe American economic system as "unique" and, contrary to the Marxist concept of capitalism, providing "the ordinary consumer with a high income" (89). Thus, the stated goal of the USIA is to promote the basic tenets of American exceptionalism. Moreover, the agency "operators" are urged to present a "show window" rather than a mirror of American life, carefully selecting facts and, when necessary, "minimizing the truth to insure credibility" (92-94). Such tactics were a mirror image of the methods used by Soviet propaganda, so it might seem remarkable that Soviet intelligentsia of the 1970s and 1980s, having learned to recognize the falsehood of its own government, bought into the fictitious image of America served by the U.S. propaganda machine. This naiveté is less surprising if one considers the duality of the Marxist worldview as well as the Russian propensity to messianic and exceptionalist thinking.

In the Soviet Union, the discourse of American exceptionalism found a fertile ground in the minds of intellectuals who were brought up on the ideas of Russian and Soviet exceptionalism but were dissatisfied with the oppressive Soviet system. As Dmitry Shlapentokh contends, "Russian Messianism was the backbone of Russian political thought throughout the country's entire modern history." Unlike other European countries, Russia had no problem in 
"asserting [its] uniqueness" as the only Orthodox (that is, truly Christian) nation and a political entity that survived for over a thousand years, constantly expanding its territory and its domination over the neighboring countries. Pre-revolutionary Russian Messianism conceptualized the country as the Third Rome, destined to lead the world both spiritually and politically (199-201). Before the 1917 revolution, the idea of Russia's unique mission was used to justify the country's territorial expansion and its involvement in the affairs of other countries. ${ }^{6}$ After the revolution, Russian Messianism was not rejected but replaced with Marxist ideology that is supposed to transcend national boundaries and unite people on the principle of class. Similarly to Americans who saw the United States as an unprecedented experiment in democratic polity, Communist propaganda stressed the uniqueness of the Soviet attempt to build socialism and eventually communism. Using rhetoric similar to that of American Manifest Destiny discourse, the 1961 Program of the Communist Party described the path traversed by the Soviet people on their road to socialism as "unexplored and arduous" (21) and chronicled numerous obstacles they had to overcome "in keeping with the interests of the international proletariat and all mankind" (13). The Program also claimed for the Soviet Union the role of "a reliable bulwark" in humanity's struggle against exploitation, injustice, national and gender oppression, and wars of conquest (21). In other words, the ideology of Communism was, as Dmitry Shlapentokh puts it, "imbued with messianic and global dimensions," suggesting "Soviet leadership in the world community" (202). Superimposed on the traditional Russian Messianism, this ideology reinforced the myth of Russian (and Soviet) exceptionalism.

The influence of the Communist Messianism inside the Soviet Union peaked during the years of Khrushchev's relatively liberal rule (1953-1964) and declined precipitously during the 1970s and the early 1980s. After the 1956 denunciation of Stalin's crimes and the mass release 
of political prisoners, the country opened up to the world and was becoming a pioneer in space exploration. Large-scale industrial construction and the development of new agricultural lands as well as of vast natural resources in Siberia seemed to assure the soon-to-be-achieved well-being for ordinary people, whereas the new Party Program professed a prosperous communist society by 1981. Pyotr Vail and Alexander Genis rightly observe that most people in the Soviet Union saw the Program, written in vague pseudo-scientific language, as a "poetic abstraction" rather than a practical plan (10), but this utopian document added to the optimistic mood of the Soviet 1960s. ${ }^{7}$ When under Brezhnev the liberalization trends were reversed and the promised affluence did not materialize, many Soviet intellectuals lost faith in the communist ideal. Some of them clung to the belief in Russia's unique mission in the world, reverting to the idea of Russian Orthodox spirituality. For others, who turned to the West in their hopes of finding solutions to the philosophical and political conundrums of the modern world, accepting the idea of American exceptionalism became a logical step. Still viewing the world through the Marxist binary, they were able to switch sides in the opposition but not to collapse it. Instead of becoming disillusioned, they swapped one illusion for another, and many of them left their home country for the place of their dreams.

Authors discussed in this dissertation contribute to our understanding of the link between the American Dream and place-connectedness. They describe their idealized notion of America, contrasting it to the culture that bred this illusory image. In the regimented worlds of the Pale of Settlement and of the Cold-War Soviet bloc, they dreamed of America as a Promised Land, a land of riches, and a land of cosmopolitan culture. They exemplify a scope of reactions to American encounters - from Antin's exaggerated enthusiasm to Hoffman's anguish to Limonov's anger - and of coming to terms with the disappointment in the American ideal. They 
all write from a space that is a composite of the old and the new places, of the real and the imaginary.

${ }^{1}$ Although Aksenov was forced to emigrate and stripped of Soviet citizenship, he chose the United States over Europe as his place of residence.

${ }^{2}$ Cosmopolitanism has also been criticized from the extreme right as a negation of nationalism and patriotism. In Nazi Germany and Stalin's Soviet Union, the label of "rootless cosmopolitans" was used as a justification for anti-Semitic campaigns.

${ }^{3}$ Practical applications of cosmopolitanism have been suggested in different fields: in postcolonial literary studies, Robert Spencer is developing a methodology of "cosmopolitan criticism." In political theory, Daniel Bray introduces a concept of "pragmatic cosmopolitanism," while Peter Kemp advocates cosmopolitan ideal as a philosophical basis of education. ${ }^{4}$ In immigrant fiction, Iva Pekárková's 2000 novel Gimme the Money is an example of a fragmented postmodern narrative in which New York City is presented as a complex text that is continuously re-written and re-created by the book's immigrant protagonist.

${ }^{5}$ Israel Zangwill (1864-1926) was a British writer and playwright, whose 1909 play, The Melting Pot, popularized this expression. He wrote an introduction to Antin's 1899 book, From Plotzk to Boston, and read The Promised Land in manuscript. In their long-lasting correspondence, he encouraged young Antin's talent.

Josephine Lazarus (1846-1910), the younger sister of the poet Emma Lazarus (1849-1887), was an influential figure in Antin's life: Antin named her daughter Josephine after Lazarus and dedicated The Promised Land to her memory. 
${ }^{6}$ In the European standoff leading to World War I, Nicholas II's catastrophic decisions were in part motivated by his and his government's paternalistic attitude towards Serbia, an Orthodox Slavic country, and by their wild ambition to topple Turkey and claim Istanbul (Constantinople, the Second Rome) for the Russian Empire.

${ }^{7}$ Vail and Genis define the time frame of the 1960s for the Soviet people as 1961-1968-from the adoption of the new Program of the Communist Party to the suppression of reform movement in Czechoslovakia (iv). 


\section{CHAPTER 1. "THAT ALLURING LAND": EAST EUROPEAN VISIONS OF AMERICA}

Things weren't good for me at home, and as everyone believed that in America money flowed in the streets, I decided to go. (A Bintel Brief 62)

These words were written in 1907 by a reader of the Jewish Daily Forward, a Yiddishlanguage daily newspaper that started in New York in 1897. The anonymous author of the letter to the editor pithily sums up the complex decision that every emigrant makes. The first part of the equation could be expanded into a long list of bad things that push people towards emigration: religious and political persecution, scarcity of land or jobs, aftermath of war, restrictions on creative freedom, and so on. However, without the appeal of the imagined America, economic hardships or political oppression are not sufficient. How are dissatisfied people to know that life in the United States would be any better? What do they expect to encounter upon arrival? The second contributing factor in most emigrants' decision is their belief in the riches of America and in the possibility of a better life. Another 1907 text, "That Alluring Land," a story by a Slovak author Timrava, describes "the golden threads" (122) that were pulling Slovak peasants to America:

[T]hey talked about that wondrous land across the ocean which provided mankind with such blessings. It had four harvests a year with no taxes, and money fell everywhere like dust. That land glittered magically before their eyes. It was covered by luxuriant ears of grain strewn with the dollars that rained down abundantly upon the working man and jingled like music. (117) 
Although money flowing in the streets or raining from the sky were figures of speech, many people in Eastern Europe did believe in America's abundance of consumer goods and life comforts. America was also perceived as attractive because of its political and religious freedom and its uncensored, unrestricted flow of cultural production, which was especially important for post-World-War-II intellectuals.

Serving as a historical background for immigrant literature, this chapter analyzes the images of America that motivated emigration from Eastern Europe. In addition to existing scholarship, I rely on interviews with immigrants and on my personal experience of life in the Soviet Union to scrutinize the following official and alternative sources from which citizens of the Second-World countries learned about life in North America:

- Communist propaganda (including some examples of anti-American cartoons, published in 1961 in the Krasnoe Znamya [Red Banner], the Communist Party newspaper for the Kharkov Region of Ukraine where Edward Limonov, one of the authors discussed in later chapters, grew up. These examples are representative of material published in the Soviet bloc press of 1950s-early 1980s and familiar to anybody who lived in the Soviet Union or Eastern Europe during that time);

- Books by late nineteenth century and early twentieth century East European and Russian writers, such as Henryk Sienkiewicz, Vladimir Korolenko, and Maxim Gorky;

- Books by Soviet-period authors, such as Vladimir Mayakovsky, Ilya Ilf and Yevgeny Petrov, Tatiana Tess, and Vasily Aksenov, who were allowed to travel to the United States and publish their accounts of America; 
- Books by American authors;

- Letters and photographs received from recent emigrants;

- Hollywood movies and pop-culture artifacts, such as jazz and rock music;

- American Cold-War propaganda disseminated through radio broadcasts;

- $\quad$ Samizdat and smuggled books. ${ }^{1}$

Communist propaganda, this ubiquitous function of a seemingly omnipotent government, proved to be powerless in its efforts to inculcate in the citizens of the Soviet Union and Communist bloc countries a negative image of the United States. Propaganda's persistent focus on America mythologized this country, giving it a status of an unassailable ideal, thus stimulating constant interest in American culture and way of life. Despite the Communist governments' monopoly on information, numerous unofficial sources - including the outreach by U.S. propaganda agencies — appeared to be more credible than official Soviet media outlets and further contributed to the idealization of America. Aided by imagination, sketchy and often misleading data from alternative sources was interpreted in the light of overall infatuation with America and allowed East Europeans to develop an attachment to this mythical place. The resulting image was in many respects similar to the standard American Dream: a country of boundless riches and endless opportunities; of fabulous technological sophistication; of near classless society; of political, religious, and artistic freedom. With the decline of socialist economy in the 1970s and 1980s, East Europeans came to believe in the superiority of American political and economic systems. Inspired by the vision of ideal America, many of them chose to leave their own countries for the New World. The dream of America took shape in the process of emigration, with every new generation of migrants adding a reference for their successors. 


\section{EAST EUROPEAN EMIGRATION: A BRIEF OVERVIEW}

Many East European nations claim a long history of emigration to America. Names of Tadeusz Kosciusko and Kazimierz Pulaski, Polish heroes of the American Revolution, can be found in U.S. history books, but the first Poles arrived on the North American continent practically with the first British settlers. According to Frank Renkiewicz, in 1608 John Smith recorded the arrival of eight Dutchmen (Germans) and Poles who were hired "to make pitch and tarre, glasse, milles, and sope-ashes" (41). As Thomas Čapek notes, Czech Protestants started coming to America as early as the first half of the seventeenth century (vii); in the 1800 s, the numbers of Czech immigrants increased dramatically as a result of the failed revolution of 1848 and of economic hardships (25). During the years of California Gold Rush alone (1848-1855), twenty-five thousands of Austrian citizens (most of them ethnic Czechs) arrived in the United States (28-29). Tim Prchal observes that 1880 marks a change in the ethnic composition of immigrants. After this date, East and South Europeans coming to America outnumber their northern and western neighbors (5-7). For example, from the 1870 s to 1914 , the number of Poles who left for America reached 2,600,000 (Gieystor et al. 584-585); from 1881 to 1921, two million Russian and Polish Jews, most of them from the Pale of Settlement, emigrated to the United States (Orleck). Ethnic Russians claim the settlement of California and the exploration of Alaska in the early 1700 s as their accomplishment, but their immigration to the United States was not numerous. Roger Daniels notes that although the number of newcomers from Russia during 1901-1910 exceeded a million and a half, only forty thousand of them claimed Russian as their mother tongue, with the majority being speakers of Yiddish or Hebrew, Polish, Lithuanian or Lettish, and German (217). It was the ethnic and religious minorities of the Russian Empire that were seeking refuge in America. The borders of East European countries changed many times during the twentieth century, so some emigration statistics figures might overlap, but the 
numbers are still impressive, even more so in comparison to the dramatic decline of in the numbers of East European immigrants that occurred in the following decades. ${ }^{2}$

The early-twentieth-century massive influx of immigrants aroused fear and suspicion in many Americans. They felt threatened by the newcomers' religions (Catholic, Eastern Orthodox, Jewish) and their strange customs; arriving immigrants were perceived as competitors on the job market. As a result, by the 1920s, the U.S. government adopted a series of laws that closed the doors on mass immigration for groups considered undesirable, including East Europeans. Gary Gerstle writes that in the wake of anarchist terrorist acts in 1919-1920, East European Jews were singled out as the source of the "Red Scare" (228-232). Responding to the xenophobic propaganda of Ku Klux Klan and other nativist groups, the U.S. Congress set to restrict admission not only of Asian immigrants who were considered a "yellow peril" but also of "inferior" ethnic groups from the hinterlands of Europe. This policy, often referred to as "the triumph of nativism" (Daniels 263), culminated with passage of the Immigration Law of 1924 that established immigration quotas and visa requirements with the goal of "limit[ing] immigration and $[\ldots]$ reconstitut[ing] its sources away from Southern, Central, and Eastern Europe towards north-western European nations" (U.S. Immigration 129). For instance, quotas for 1929, signed by President Hoover, include 100 persons each for such countries as Afghanistan, China, Cameroon, and Japan; 2,874 for Czechoslovakia; 6,524 for Poland; 2,784 for European and Asiatic Russia; 17,853 for Irish Free State, 25,957 for Germany, 65,721 for Great Britain and Northern Ireland (U.S Immigration 164). Although these figures were supposed to reflect the number of immigrants of each ethnic group already present in the United States, they also illustrate the hierarchy of nations created by the racist ideology that dominated the political debate of the time. 
The 1920s was also the decade when the social make-up of emigration from Russia changed. If peasants and shtetl Jews were the majority of the previous wave, the post-1917 migrants were mostly political refugees fleeing from the revolutionary terror. After spending a decade as Europe's displaced persons, many of them moved to America to escape the growing Nazi menace. In contrast to their poorly educated, often illiterate predecessors, most of the immigrants arriving in the United States in the 1920s and 1930s belonged to educated classes. This change had literary and cultural consequences for America: by comparison with earlytwentieth-century immigrants, the later arrivals produced a large body of autobiographical writing and made a significant contribution to the artistic life of the United States. Names of Vladimir Nabokov, Ayn Rand, Igor Stravinsky, and Sergey Rachmaninoff are widely known, but there were scores of others. ${ }^{3}$ All these books were published in the West and a few were familiar to Soviet readers who were not supposed to learn the truth either about life before the revolution or about the life of emigrants.

After World War II, devastated Europe was full of displaced people, refugees from Soviet-occupied territories, and Soviet citizens who had been imprisoned by the Nazis or could be seen as Nazi collaborators (the punishment for both offences was death or long imprisonment in labor camps). Many of these people were trying to escape to America where, as Karen Brodkin notes, the war against fascism caused a change in attitude towards Jews and East Europeans, leading "to a more inclusive version of whiteness" and to the end of restrictions that had previously hindered for these groups advances in education and on the job market $(36,44)$. However, the xenophobic and anti-Semitic sentiments still circulated and influenced the immigration debate so that attempts to raise the immigrant quotas often met with fierce resistance. According to Daniels, Americans were afraid of a potential flood of refugees, of 
Communist infiltration, and of "a plot to let in more Jews" (329). Against the opposition, in 1948, the Displaced Persons Act was passed, setting, for the first time in American history, "refugee policy, as opposed to immigration policy" (330). Daniels quotes about 450,000 as the total number of displaced Europeans admitted to the United States in 1945-1952 (331). In spite of the anti-Communist paranoia of the 1950s, the laws that were supposed to keep East Europeans out were gradually bent by legislative acts that would make an exception to different groups of political refugees, such as Hungarians escaping after the suppressed revolution of 1956.

The Immigration Act of 1924 lasted until 1965 when the national origin system was finally eliminated. Under the new Immigration and Nationality Law, immigration visas were granted to people seeking family reunification or possessing skills that were in demand in the United States, as well as to refugees from Communist or Communist-dominated countries (Daniels 340-342). The latter provision opened the golden door to dissident intellectuals who were able to escape or legally emigrate from the Soviet Union and its satellites. Post-World-WarII emigration from the Soviet bloc countries was a complex phenomenon, fueled both by the desire to escape political, religious and ethnic persecution and by economic discontent. As Marcin Kula argues, there has never been a sharp boundary between political and economic reasons for emigration from Eastern Europe. Even for people who left their home countries as a result of political upheavals (such as the failed Polish uprisings of the 1800s or the Soviet-led invasion of Czechoslovakia in 1968), "economic factors that made people stay abroad at least joined the political ones as the stay there was prolonged" (47). Still, until after World War II, political and economic emigration could be distinguished as somewhat separate phenomena. By contrast, in the post-war period, the two motives became further conflated. In the Communist 
bloc countries, since the state dominated and controlled most aspects of human life, its subjects blamed the system — and justly so — not only for the restrictions on freedom but also for their material hardships (48). The large and petty inconveniences of life described by Kula—from the shortages of toilet paper to the absurd management methods—-were as much part of Soviet as of Polish reality. As in Poland, "the nightmare and humiliation were directly projected on the political system prevailing [...] at that time" (49). Most importantly, Party control stifled intellectual life and artistic expression in Warsaw, Moscow, Prague, and Leningrad, pushing East European intelligentsia towards leaving their home countries.

During the Cold-War years, it was possible — although not easy— to escape to the West by defecting and by emigrating officially. Among defectors who came to live and work in the United States are such prominent figures as Arnost Lustig, Czech writer and Holocaust survivor; film directors Milos Forman and Roman Polansky; ballet dancers Mikhail Baryshnikov and Alexander Godunov. On the other side of the divide, Soviet-bloc authorities had to give in to international pressure and grudgingly allow emigration, mostly to Jews who were ostensibly leaving to be reunited with their relatives in Israel. Contrary to this official version maintained both by the Soviets and the West, not all emigrants were Jews. For once, being Jewish in the land of official anti-Semitism was seen as an advantage, so that people of Russian and other ethnicities were "pretending to be Jews so that they can get out" (Daniels 387). This fact further attests to the complexity of motives for leaving. Many emigrants chose to go to the United States, Canada, or Western Europe rather than to Israel. According to Victor Zaslavsky and Robert J. Brym, the total number of emigrants who left the Soviet Union in 1971-1981 is over 250,000, with thirty-eight percent ending up in the West (52). Soviet authorities made the process of emigration not only bureaucratically difficult but also dangerous. In most cases, 
applicants immediately lost their jobs, which made it hard for them to survive during the many months or even years of waiting for an exit visa. Moreover, they were routinely harassed by the secret police and ostracized by their neighbors, former friends, and colleagues. For refuseniks, or those whose applications were denied, the nightmare of jobless and powerless existence stretched for years. In this desperate situation, informal networks of support—always important in the Soviet Union - would become the only means of survival. Trusted friends and relatives provided refuseniks with financial assistance and safe places to hide from KGB harassment. Emigrant samizdat activists circulated information unavailable from official sources: brochures that explained the applicants' legal rights, instructions on how to appeal one's case, addresses of foreign embassies and international organizations where one could receive assistance. More than anything else, it was the dream of a better life in a better place that helped would-be emigrants overcome their fear and despair.

\section{IMAGES OF AMERICA}

During the 1870s-1910s, the decades of highest emigration from Eastern Europe, no government was involved in the systematic dissemination or restriction of information about the New World. People traveled freely_ by comparison with later decades — as did letters and other media. For the illiterate or semi-literate peasant population, images of America came from letters written by emigrant relatives, friends, and neighbors as well as from representatives of shipping companies. Educated classes learned about America from newspapers, from books written by American and domestic authors, and from the newly arriving samples of American pop culturemusic and movies. In East European cultures, literary images were significant components of the overall conception of America. Texts by both American and domestic authors played a role in shaping public opinion and feeding individual imagination. The influence of literature was the more prominent during the decades of the Communist rule because of the socialist-realist 
premise that literature is a mirror of life, which as Carl Proffer notes, resulted in a belief that "what is true of American literature is also [...] true of the American people" (Preface ix). Books were purposefully used by Communist propaganda to show the struggle of oppressed working people, to expose the inhumane nature of capitalism, and to prove its inevitable demise.

During the decades of the Cold War (1946-1989), Communist propaganda was by far the most powerful and omnipresent influence on the outlook of East Europeans. They were exposed to a continuous stream of ideological material from newspapers, radio, and television, the goal of which was to create a horrifying picture of brutal American capitalism. Political commentaries covered all aspects of American life: economy, politics, culture, the life of ordinary people, and the activities of the Communist Party of the U.S.A. They used carefully selected facts, not hesitating to exaggerate or invent details for stronger effect. However, the resulting picture was hyperbolic and contradictory. In the light of information from alternative sources and in contrast to the reality of Soviet life, the propaganda concept of America gradually lost its credibility and was transformed in popular imagination into its opposite. Most importantly, the propaganda lies about the Soviet Union revealed the government's mendacity. Having stopped believing official success stories, Soviet citizens also dismissed the tales of American misery, elevating the United States to the status of a consumer paradise.

Although Communist governments had monopoly on book publishing and would not allow any anti-Soviet or pro-American texts to see the light of day, starting in the 1960s East European readers acquired access to forbidden literature that was copied and distributed domestically (samizdat, or self-publishing) or smuggled from the West (tamizdat, therepublishing). ${ }^{4}$ Increasingly, texts that revealed the nature of totalitarian societies or gave favorable accounts of life in America were available to and made impressions on Soviet and Eastern bloc 
intellectuals. The attitude of Soviet authorities to Western pop culture oscillated: from the austerity of the revolutionary period to the permissiveness of the 1920 s and early 1930 to the tightening of restrictions in the pre- and post-war years. Many forms of mass culture-music (first jazz and later rock), films, radio broadcasts, clothes, visual arts and design — circulated behind the Iron Curtain and became an important source of Western imagery for Soviets and East Europeans.

Before the Wall

Turn-of-the-twentieth-century mass emigration from Europe was a profitable enterprise, and shipping companies did their share of advertising the riches of America, dispatching thousands of agents to remote territories throughout Europe. Frederick Bushee asserts that in 1891 "nearly four thousand emigration agents and subagents" operated in Italy and that by 1900 this number grew to seven thousand" ("Ethnic" 5). Even residents of distant villages were influenced by "the placards [that] went up at the chapel gate or by the side of the inn" (Handlin Uproooted 38). During the same decades, emigration agents were operating throughout Eastern Europe and western provinces of Russia. A Soviet historian N. L. Tudorianu reports that in the early 1900s Russian peasants in the United States said that "“emigration agents' convinced them to go to the land where "gold lay on the streets"' (qtd. in Archdeacon and Senn 129). There were also some private Jewish organizations that provided prospective emigrants with information in Yiddish and Hebrew. Gur Alroey notes that newspapers of the era often published stories of obstacles that prospective emigrants encountered on their way to America. To help emigrating Jews prepare for the journey, in 1903-1907, six emigration bureaus were established in the Pale of Settlement. Rather than direct emigrants to a particular country (such as America, Argentina, or Palestine), the goal of these organizations was to provide information about different destinations (37). Despite the availability of contradictory accounts, most people still put their 
faith in the myth of hospitable America—often under the influence of letters that confirmed their highest hopes.

Letters sent to Eastern Europe from the United States often failed to provide truthful information about life in America or to warn prospective emigrants about the dangers and disappointments that awaited them. Instead, letters seem to have reinforced the glowing image of America, in part because most immigrants did not want to acknowledge that American reality fell short of their expectations. Two of the authors discussed in later chapters-Antin and Hoffman —admit to having lied in their letters home. In addition, specific details contained in letters were often misconstrued when taken out of a broader cultural context. In Timrava's story quoted above, this process of misinterpretation is exemplified by the reasoning of Prívoda, a Slovak peasant who is sure that in America he will become a gentleman. Prívoda's confidence is based on the details he has learned from letters and rumors: "When I earn five dollars a day, that's thirty dollars a week, isn't it? You know what one dollar will pay for, so when every Saturday I have thirty dollars in my pocket, that makes me a gentleman, doesn't it?" (115). Not only is Prívoda overestimating his earning capabilities — as the readers learn later, he and his fellow-immigrants will actually be making three dollars a day — but he is also misjudging the cost of living in the United States. This scene echoes a text more familiar to American readersUpton Sinclair's The Jungle, with a similar discussion in which a Lithuanian peasant Jurgis Rudkus and his family are estimating their prospects in America. In both texts, would-be emigrants rely on a combination of facts and fiction, choosing to believe what they want to be true.

During this period, images of America were becoming part of East European high culture, with major literary figures traveling to United States and publishing both their accounts 
of the journeys and fiction based on their American experience. One of the first Eastern European authors to write about America was Henryk Sienkiewicz, a Polish writer, who visited the United States in 1876 (Poland was then part of the Russian Empire). During that decade, mass emigration of Poles to America was just beginning, and Sienkiewicz's books reflected his own and the public's keen interest in America. According to Charles Morley, thirty-year-old Sienkiewicz was curious to see "the land of mystery" where few of his compatriots had been (x). According to his friends' accounts, the young author spoke about America "in the most glowing terms" and agreed with people who considered California to be "indeed the Promised Land where game of all kinds might be had for the shooting, fruits of every variety grew at least three times larger than anywhere else, coffee, pepper, and castor-oil beans grew wild, and gold was to be found almost everywhere." Eventually, Sienkiewicz joined a handful of his equally enthusiastic friends who decided to go to California and start a utopian community modeled after Brook Farm (xi). ${ }^{5}$ This experiment in communal farming failed, and Sienkiewicz returned to Poland, but his two-year sojourn in the United States inspired several works of fiction and a book of essays, Portrait of America. As Morley points out, America "alternately intrigued, repulsed, and attracted" Sienkiewicz (xvi), so it is not surprising that his books reflect this ambivalent attitude. Thus, the protagonists of the dark and pessimistic After Bread, father and daughter Lorentz and Mary Toporek ruined by a neighbor's lawsuit, decide to leave their Polish village and seek their fortune in America. The misfortunes that befall them include putting all their money into a doomed Polish settlement in Arkansas. Disorganized and quarrelsome, violent and hateful toward one another, the settlers fail to sustain their camp and build it into a village. The little they have is finally swept away by a mighty flood, in which Lorenz dies, leaving Mary alone in the world. She manages to get back to New York with an intention to return to Poland, 
but does not have money to pay either for the passage or for food and lodgings. After weeks of futile begging to be let on one of the Europe-bound ships, Mary goes insane and dies on the dock.

Even in this tragic story, Sienkiewicz is not pronouncing a judgment on America. Rather, he spreads the blame around and lists many factors that contribute to his protagonists' harsh life and ultimate failure. It is the callousness of the Hamburg steamboat ticket agent who "received commission from his sales, and cared for nothing more" (52). He lets Lorentz believe that on their arrival in New York a government officer will come and ask for them, which compels father and daughter to wait on the dock for days (48). It is also the Toporeks' Old-World lack of initiative that renders them helpless without an authority figure that would tell them what to do. Finally, it is the immigrant section of New York, a place of "dirt, filth, disorder, and human misery" (56). Sienkiewicz contrasts the Polish village where even a beggar could live "as a bird who neither sows nor plows" to "this great city, that hummed like a mighty engine, [where] everybody rushed onward and looked only ahead, so that they could not see the suffering of others" (61). This picture of New York emerges in sharp contrast with the author's initially radiant image of America as a Promised Land.

After Bread could have served as a warning to would-be emigrants from Poland if it were not for Sienkiewicz's other accounts of the United States. In Portrait of America, Sienkiewicz comes to the conclusion that America is a place of social equality, which is based on three principles: "1) respect for labor; 2) absence of great differences in education; 3) lack of marked disparity in manners" (96). Not only does the author declare America "the better civilization" by comparison with Europe (98), but he also draws a sharp distinction between the "highly moral character" of American society on the one hand and its port cities on the other hand. In the latter, 
"immigrants lead miserable existence until they find employment" (104) and "commit numerous crimes" because of their poverty (101). Sienkiewicz claims that in America, freedom is "a practical reality" (267) and that nobody "attempts to Americanize you or to force anything upon you" (288). Nevertheless, he predicts complete assimilation for Poles and other ethnic groups who "sooner or later transform themselves into Americans in spirit" and accept the English language (288). Ultimately, Sienkiewicz's writing reinforces the myth of America as an exceptional country, superior to what European civilization has to offer. Sienkiewicz is a widely read author in Poland, and the positive image of America he creates remains influential.

One of the first Russian authors to write about America was Vladimir Korolenko. He visited the 1893 Chicago World's Fair and published his novella In a Strange Land in 1895. The book tells the story of a Ukrainian peasant, Matvai, who accompanies his sister going to America to be reunited with her husband. Matvai gets lost from his sister and his other companion and wanders around New York, unable to communicate with anybody or to comprehend what is going on around him. His actions, such as attempts to show respect and admiration by kissing hands, are misconstrued and met with hostility. The Russian title of the book, Bez Yazyka (Without a Tongue), is as ambiguous in Russian as it is in English. It underscores the helplessness of a newly arrived immigrant, an alien to the language and the culture of the host country. The book is also full of Matvai's musings about America and his homeland, Ukraine:

That America, about which it was so sweet to dream on the quiet banks of the Lozovaya or on the steamer rocking on the water at sea $[\ldots]$ — that America was gone. [...] How can one find happiness in this Hell where people rush as though mad, over the ground and under the ground and even, God forgive them, through the air; where everything is entirely different from what one is accustomed to at home; where it is impossible to 
distinguish to what social class a man belongs; where it is impossible to understand a word of what they say? (52)

After a series of misfortunes, Matvai leaves New York on a west-bound train. Still lacking any language or social skills, he seems to be headed towards a final disaster. Quite unexpectedly, the book ends happily: in Doubletown, Minnesota, Matvai meets a compatriot who not only translates for him but also explains to townspeople the actions of this "notorious wild man, the instigator of regrettable riot in Central Park, the strange man whose character was misrepresented all over America" (195). Matvai settles down in Minnesota and works hard to fulfill his dream. He soon becomes the owner of "a piece of land, a house, cows and calves" (213) and marries the woman he loves. Korolenko's optimistic picture of America describes the trials of adjusting to a new place and a new culture but also shows how good luck and hard work help overcome all obstacles.

The next major writer to publish books about America in Russia was Maxim Gorky, Korolenko's younger contemporary. Unlike Korolenko, a humanist and a critic of any oppressive regime, be it tsarist or communist, Gorky was all too often an obedient instrument of Lenin's Bolshevik Party and later of Stalin's ideological apparatus. The purpose of his 1906 visit to the United States was to raise funds for the Bolsheviks. During his sojourn in the Adirondacks, Gorky also wrote his famous novel Mother. In America, Gorky had a reputation as a talented young revolutionary writer and was met, according to his letter to L.B. Krasin, "with great pomp and ceremony" (126). Gorky left two contradictory sets of accounts of this trip. In his private correspondence, he expresses his mixed feelings about America: wonder, admiration, and disgust. In a letter to K.P. Pyatnitsky, he exclaims, "My, what an interesting country! You should see what these devils are doing, how they work, how full they are of energy, ignorance, 
smugness and barbarity! I admire them and I curse them, I feel sick and gay and damned amused!" (132). By contrast, the articles that Gorky wrote for publication distilled and exaggerated his worst impressions, resulting in a caricature of America.

The most famous in the series is The City of the Yellow Devil, in which the author describes the silhouette of New York as "a vast jaw, with uneven black teeth" and compares entering the city to "getting into a stomach of stone and iron [...] that has swallowed several million people and is grinding and digesting them" (9). Not only is the city ugly, grimy, and monstrous, but it also harbors "a life without sunlight, without songs and happiness, in captivity of exhausting toil" (8). The inhabitants of the city appear to be insignificant and enslaved, lacking "inner freedom, the freedom of spirit" (10-11). The author compares New York children to "flowers tossed by a rough hand out of the window into the dirt of the street" and portrays them as pale and sallow creatures, with poisoned blood and irritated nerves (12-13). Alayne P. Reilly argues that such hyperbolized descriptions resulted from Gorky's failure to collect sufficient funds for the Bolshevik cause (11). That might be true, but Gorky's writing also served an ideological purpose: at the time when many progressive people in Russia were advocating the route of Western-style democracy, Lenin's party was pushing towards the overthrow of both the monarchic system of government and of the rapidly developing capitalist economic system. Gorky's role was to discredit the latter as exploitative and inhumane. His highly biased account of America foreshadows the propaganda literature of the later decades. As Reilly observes, The City of the Yellow Devil became "a prototype, in style and content, of the Soviet literary image of America" (4), although Gorky's horror picture remains unsurpassed.

After the 1917 revolution, as the young Soviet society grew more and more isolated, permissions to travel abroad were granted only to the few selected writers and journalists who 
had proved their loyalty to the Communist Party. In most cases, the authors were expected to suppress their admiration of America and to deliver some incriminating material about "decaying" capitalist society and corrupt American imperialism. There were always ideological requirements to fulfill and even standard images to employ—many of them indebted to Gorky's early articles. Books that resulted from these efforts were usually a mixture of praise and invective.

Vladimir Mayakovsky was among the first Soviet writers to visit the United States and to create a controversial picture of America, allowing his fascination to seep through his communist beliefs. Mayakovsky is one of the founders of Russian Futurism, and, as Svetlana Boym points out, "[h]is repertoire of masks [...] includes among others the masks of Futurist-urbanist, of a technology lover (as opposed to the Romantic nature lover), and of an author-producer, a functionary of the technocratic postrevolutionary state" (147). Naturally, Mayakovsky is critical of the citadel of capitalism but also awestruck by America's technological advances. His "Brooklyn Bridge" is an ode to this wonder of technology and craftsmanship:

What pride

I take

in that steel mile,

and from it arose

a living vision-

the struggle

for construction

instead of style,

the stern calculation 
of steel

precision.

I stare,

as an Eskimo out-stares an express,

drinking it in,

like a drowning man air,

Brooklyn Bridge-

yes....

is something

beyond compare! (337-340)

Earlier in the poem, the poet compares his experience of stepping, or rather "clambering," on to the Brooklyn Bridge to the feelings of "a fervent believer" entering a church, of a warrior foraying a newly conquered town, and of a "beauty-drunk artist thrust[ing] his eyes into a museum-madonna" (336). In this poem, Mayakovsky is ready to give praise where praise is due (336), and he does not forget that the Brooklyn Bridge is an American creation.

In his other poems, Mayakovsky follows Gorky's model of "hyperbolic naturalism" (Reilly 14). He creates caricature images of greedy, money-crazy Americans who are born with “eyes like nickels" and greet each other with "Make money?” instead of "Good Morning” (qtd. in Reilly 13-14). In “Challenge,” Mayakovsky contrasts America’s preoccupation with money making to his own "disdain for material possession":

I throw to the swinish devils

All dollars 


\section{of all countries.}

I'd like to end my life

in the trousers

I started in,

accumulating

nothing

through my life. (qtd. in Reilly 15)

Here Mayakovsky is not only following the Communist ideal of austerity and self-sacrifice but also sets another standard of anti-American imagery that will be touted in Soviet literature for decades to come - the animal greed of capitalists. In another poem, "Americans Are Astounded," Mayakovsky writes about the curiosity and bewilderment of "corpulent" Americans over the "zeal" and "steel discipline" of Soviet workers during the first five-year plan (390). He repeats the Party slogan that cheers the Soviet people in their economic competition with the United States:

Bourgeoisie,

astonish

at our Communist shores-

in aeroplanes,

on tractors,

at whatever work task,

your world-famous,

streamlined America,

for sure, 
we

shall overtake

and surpass. (391)

During the early years of Soviet power, Mayakovsky worked as a propaganda artist for ROSTA, Russian Telegraph Agency. He was among the creators of the visual stereotype of the fat American capitalist that circulated throughout the country via agitprop posters and survived until Perestroika time in political cartoons. Zubok quotes Alexei Kozlov, a jazz musician, who recalls in the 1990s that "Americans were depicted in two ways - either as poor, unemployed, gaunt, unshaven people in rags or as big-bellied bourgeois in tuxedos and top hats, with a fat cigar in their mouths. And there was a third category_-hopeless Negroes, all of them victims of Ku Klux Klan” (104). These images first appeared in ROSTA posters that helped spread Mayakovsky's popularity both as an artist and as a poet.

By the end of the 1920s, Mayakovsky's relationship with Soviet literary authorities became strained, which was one of the reasons for his suicide in 1930. Still, soon after his death, he was idolized as a preeminent proletarian poet and his poems became part of the official literary canon. Moreover, because of his talent and his experiments in poetic form and language, Mayakovsky — and his image of America — has remained a favorite with the Russian reading public.

After Gorky and Mayakovsky, both traditions_ - of disparaging and of admiring America - continued in Soviet literature for decades, and the ratio of condemnation and admiration depended on the political climate of the time and the courage of the authors. ${ }^{6}$ By far the most popular and enduring book about the United States, The Little Golden America, was written in 1936 by Ilya Ilf and Evgenii Petrov, long-time collaborators and authors of popular 
satirical novels. ${ }^{7}$ In 1935, Ilf and Petrov spent four months in America traversing the country by car. Like Mayakovsky before them, they admired New York, "an excruciating city [that] constantly rivets all attention to itself. It makes your eyes ache. Yet it is impossible not to look upon it" (39). Unlike Gorky and Mayakovsky, Ilf and Petrov ventured out of the big cities and reported their interaction with ordinary Americans who were "remarkable people [...]. It is pleasant to be friends with them, and it is easy to do business with them" (34). Ilf and Petrov also attempted to analyze American national character with all its "splendid and appealing traits":

They are excellent workers; they have golden hands. Our engineers say that it is a genuine pleasure to work with Americans. Americans are precise, yet far from pedantic. They are neat, they are accurate, and they trust the words of others. They are always ready to come to your aid. They are excellent comrades, and easy to get along with. (173) Ilf and Petrov are not afraid to note the high quality of American roads, the prompt and friendly service offered at gas stations and motels, as well as the "faultlessly organized" and inexpensive recreation at national parks (212). On the negative side, the authors list a lack of curiosity displayed by numerous hitchhikers they meet who are not in the least interested in finding out who these foreigners are or where they come from (173-174). True to their ideology, Ilf and Petrov comment on the tendency of American business owners to mercilessly replace workers with machines (95) and on the contrast between the rich and the poor (75). However, as Reilly observes, the authors ascribe the latter problem only to big cities, such as New York and Chicago, rather than to small towns (33). In Reilly's words, Ilf and Petrov "do not harp on the tiresome themes of propaganda" (31) and maintain an unemotional tone of objective reporters (38). Ilf and Petrov record what they do and do not like in America and do not suppress their admiration for this "amazing country" (167). 
How could Ilf and Petrov write a favorable book about America and get away with it in Stalin's Russia? First, the path of capitalist development that existed in Gorky's time was no longer an option (or a danger, as the Party would put it). Moreover, America did not become number-one enemy of the Soviets until the Cold War of the 1940s-1980s. Although in the 1930s the relations between the two countries were not smooth and the United States did not recognize the Communist government until 1933, neither the Soviet Union nor the United States were competing for world domination. Most importantly, in the race to educate its people and industrialize its economy, Stalin's regime relied heavily on foreign experts, Americans in particular. In 1931, Eve Garette Grady reported in the Saturday Evening Post that "[m]ore than 1000 American engineers invaded Russia in full force [...to supervise] the construction of factories, mines, railroads, irrigation works, hydroelectric power plants, and other structural enterprises" (42). In fact, according to Sylvia R. Margulies, Soviet recruiting agencies seemed to favor American engineers over specialists from other countries because of the importance of assembly-line technologies for the Soviet industries (70-71). The presence of Americans is reflected in the Soviet literature of the time. Analyzing Soviet industrial novels of the 1930s, Vera Alexandrova observes that these texts portray American engineers as inquisitive and thoughtful people:

A kind of organic social democracy is inherent to them, due to a certain primitiveness and youthfulness of American culture. It was just that primitive democracy that helped the Americans to penetrate into the depth of the living Russian people, to sense their originality, their talent, and their great, only partly realized potentialities. (26) Although different from the industrial novels in topic, Ilf and Petrov's book is emblematic of the time when pragmatic considerations eased ideological restrictions and allowed authors to show 
Americans as human beings rather than caricatures. Still, the book encountered severe criticism and was published with significant deletions. ${ }^{8}$ Unlike industrial novels whose popularity did not last past the industrialization era, Ilf and Petrov's travelogue became "a cult book" in the 1960s (Vail and Genis 53) and a major literary source of American imagery until Perestroika.

In addition to travelogues by domestic authors, America became familiar to educated East Europeans from books by American authors. Carl Proffer claims that the Soviets have "a long tradition of respect for translation of literature as a responsible art" and that Soviet translators of American literature "are vastly superior to their American counterparts" (Preface Xv). As a result, many nineteenth-century American authors were popular, and every educated person would have read or at least heard of Fenimore Cooper, Mark Twain, Edgar Allan Poe, Harriet Beecher Stowe, and Walt Whitman. ${ }^{9}$ Katerina Clark observes a paradoxical trend in the Soviet culture of the 1930: as the Soviet Union became an increasingly closed society, the number of published translations of works by major European and American writers grew (16). Texts that were considered classics of "world literature" were promoted "both for domestic consumption and as an emblem of antifascist movement" (4). Clark explains this phenomenon by the Soviet Union's cosmopolitan ambition to become "the Fourth Rome"-a political and cultural leader on the global scale, with "culture, and especially literature, becom[ing] the Soviet secular surrogate for religion and central to the Soviet Union's claim to international dominance" (10). ${ }^{10}$ This tradition of translation that centered largely on Western literature continued through the twentieth century, shaping Soviet intellectuals' understanding of cosmopolitan high culture.

Despite its openness to the literature of previous epochs, Soviet literary authorities of the 1920s-1950s were very selective with twentieth-century American and other Western authors, favoring those who were affiliated with the Communist Party or at least displayed working-class 
sympathies. As Carl Proffer notes, any text that was classified as "realism" or, even better, as "critical realism" was preferable to "modernism," the latter meaning "anything from use of stream of consciousness devices to radical experiment in form" (Preface xvii). ${ }^{11}$ Although most texts by American authors were approved because of their propaganda value, they became popular with Soviet readers. Richard Stites quotes a survey of young peasants conducted in the Leningrad region in the 1920s. The resulting list of nine favorite books included Upton Sinclair's King Coal and Jack London's The Sea Wolf (44). London's stories of adventure had a special appeal during the time when Soviet people were set on conquering nature and overcoming obstacles on their path to communism.

Unlike the Soviet Union, between-the-wars East European countries were open to a variety of literary connections with the world, with America in particular. The same books that in the Soviet Union were used for anti-American propaganda because they were supposed to reveal the evils of capitalist society were also available and popular in Eastern Europe, but they did not necessarily arouse animosity towards the United States. Thus, in the 1920s Czechoslovakia, Dreiser's novels, Sister Carrie, Jenny Gerhard, and An American Tragedy were translated and published to great acclaim. As Stanislav Kolář notes, Dreiser’s fame in Czechoslovakia resulted to large extent from his partially Czech ancestry, from his interest in Czech culture, and from his visit to the country in the mid-1920s (56). Other authors were also influential. In a 1997 interview, Josef Škvorecký, a Czech-Canadian writer who was forced to leave his country after the 1968 Soviet-led occupation, recalls his first literary attempts during the 1940s, when he was influenced by Hemingway's Farewell to Arms as well as by Faulkner, Ring Lardner, Damon Runyon, and, "of course," by Mark Twain (Solecki 88). When Škvorecký started to "pen down [his] elaborate dreams, and created a series of unfinished first chapters of unfinished adventure 
novels," he imagined his protagonist as "a small-town boy from Bohemia [...who] was to emigrate to America [and] enjoy the successful career of a gangster in Chicago" (622). Young Škvorecký's dream of a gangster career demonstrates how a social evil can be transformed into a romanticized vision of American urban life, whereas his familiarity with Lardner and Runyon, American journalists of the 1930s and 1940s, shows that the ties between the two countries remained strong during the years of Czech independence and that American literature and newspapers were available to the reading public. After the establishment of Communist rule in the late 1940s, however, the reading lists of East Europeans were reduced to the Party-approved "progressive" authors.

In contrast to high culture and serious literature, turn-of-the-twentieth-century popular literature presented images of America as a land of adventure. In particular, books of Karl May (1842-1912), a German author of westerns, were translated and published in Russia and other East European countries. ${ }^{12}$ Although May didn’t visit America until after his famous novels were published, he wrote confidently about the life of the Wild West. As Jeffrey L. Sammons observes, May’s “experiences were fabricated and their details were cobbled together from books" (230). Sammons also notes that the first-person narrator of May's adventure novels is usually a superman who can "outshoot, outride, outsurvey, and outthink the most experienced trapper or scout, outstalk and outwit the most skillful Indian.” Moreover, the narrator possesses "bionic strength" and exhaustive knowledge on all subjects related to the life in the New World, "from the habits of buffalo to the psychology of Indians, from trail reading to taming mustangs" (231). What is most shocking about May's protagonist is that he is usually a fresh immigrant, or, in May’s own words, “a greenhorn.” In the opening chapter of his famous novel Winnetou, May characterizes a greenhorn as somebody "who is still green, new and inexperienced in the country, 
and who has to extend his feelers gingerly if he does not want to risk giving offense" (3); nevertheless, a few pages later, his protagonist's shooting and riding skills easily win the admiration of seasoned Westerners who declare him to be "a very extraordinary, or rather a very uncommon greenhorn" (13). Even more surprisingly, the greenhorn's superior knowledge comes from reading German books about America-what Sammons calls "a recursive, literal duplicity" on May's part, a ploy to attract more readers (232). It would be an exaggeration to say that prospective emigrants took May’s western escapades at face value, but the general optimistic tone of the books must have been inspiring to those preparing themselves for an American adventure.

The early twentieth century inaugurated the arrival in Eastern Europe of American pop culture - dance, jazz, and Hollywood films. Stites notes that such dances as tango, the cakewalk, the one-step, and the foxtrot were introduced to Russia by upper classes that revolted "against the stiffness and formality of traditional balls and suppers" (15) and that Charlie Chaplin's movies were very successful in Russia in the years preceding the revolution (31). Although Bolsheviks disapproved of "bourgeois" art, all these forms of entertainment resurged after the disruption of the revolution and civil war years and, in spite of constant attacks from various-level party officials, remained popular until the mid-1930s. In 1922, for example, a newly opened movie theater in Moscow showed new American movies every week (60). Stites quotes a survey conducted among homeless boys, in which thirty out of thirty-three respondents declared American actors to be their idols, with "well over half naming Douglas Fairbanks as number one" (62). In the early and mid-1920s, jazz was played mostly by "visiting Negro ensembles," but by the end of the decade, numerous Soviet bands sprang up (48). Jazz and dance were not only tolerated but even encouraged by many high-ranking Soviet officials, and one of the 
prominent bandleaders, Leonid Utesov, was a personal favorite of Stalin (74). When mass purges started in 1936, many of the jazzmen were arrested and sent to prison camps. Very few were allowed to continue playing "at the price of converting their jazz into a Soviet product, cleansed of 'decadence"' (75). Unlike the Soviet Union, the independent East European countries of the 1920s and 1930s remained part of the West and open to Western cultural influences. Many young Czechs who later had to live under the Communist regime became infatuated with American jazz. For example, Škvorecký remembers becoming "hooked for life on that beautiful music" after listening to Chick Webb's record and to "the honeycomb resonance of Webb's singing and talking saxophones" (626). Despite the ideological restrictions that came into force in the 1940s, Western pop culture continued to spread and gain influence in the Cold-War Soviet bloc.

By the 1930s, American movies gave way to numerous domestic propaganda films that sang praise to Stalin and the glorious achievements of enthusiastic Soviet workers. Occasionally, Soviet authorities showed select American movies to prove how poor and powerless working people in capitalist societies were. Although John Ford's 1940 film The Grapes of Wrath seemed to be the perfect candidate, Soviet authorities had to pull it out of the movie houses after a few days' run because of the unexpected reaction of the audience. As Waldemar Hanasz notes, "[f]ar from being appalled, Soviet viewers were envious; in America, it seemed, even the poorest had cars and trucks, and when they were driven off the land, they had a way to go and seek a new life" (8). Similarly to books chosen for their anti-capitalist message, movies often produced the opposite effect and contributed details to the fascinating image of America

As Stalin's regime strengthened its positions, its hostility towards the United States increased. Although during World War II the very survival of the Soviet Union depended on the 
military efforts of the Allies and on the American Lend-Lease program that supplied the Soviet Army with food and ammunition, propaganda writers and poets kept disparaging greedy American capitalists as war profiteers. Alexei Surkov addressed one of his war-time poems "To a Chicago Factory Owner" who "will receive hard cash for every pound of Chicago sausage" that has been shipped on time — as a payment for the blood of Soviet soldiers and civilians (113). After the war, the same Kremlin poet accused the West ("Paris, London, New York") not only of drawing "the heroic, peace-loving, dear Soviet people" into the nuclear arms race but also of being the scions of those "scholarly lice" who tortured Galileo and burned Giordano Bruno ("Raise Your Voice" 114). This far-fetched and anachronistic declaration was part of a broader, constantly rehashed claim that Marxist-Leninist worldview directly descended from the "progressive" philosophical and scientific systems of previous epochs. Apart from the general purpose of demonstrating the cultural inferiority and the moral degradation of Western capitalism, these and similar poems were meant to tarnish the memory of the Soviet-American cooperation during the war and to replace with hatred any gratitude Soviet people might have felt towards Americans. They also set up the stage for the Cold-War confrontation that would divide the world shortly after the need for the military alliance seized.

Behind the Wall: Re-interpreting Official Images ${ }^{13}$

During the Cold-War decades, America was a constant presence in Soviet newspapers, from the central Pravda to regional and local periodicals. For example, in 1961, Krasnoe Znamya [Red Banner], a daily newspaper that was published in the Kharkov Region of Ukraine by the regional and city Communist Party Committees, offered articles and snippets of information about the United States in almost every issue. As a rule, these reports were anonymous, vaguely attributed to American or Western newspapers or news agencies. They provided statistics about the growing unemployment and the number of bankruptcies, about the 
diminishing national gold reserves and the severe shortages of residential housing. The newspaper often ran anti-American cartoons. Some of them illustrated class inequality in the United States and the hardships that American working people had to face (Figures 1 and 2); others commented on the high crime rate (Figure 3) and on the U.S. involvement in world politics (Figures 4, 5, and 6). The central figure of most Soviet cartoons was the American capitalist. As a symbol of an "obsolete" social system, he was portrayed as middle-aged or even decrepit (Figure 7). As an idle exploiter of working people who gorges himself on the fruits of somebody else's labor, he was often fat and dressed in evening clothes, with a signature cigar in his mouth (Figures 8 and 9). He also hated the USSR. whose projected economic success gave him a headache (Figure 10). He was always contrasted to strong but miserable American workers as well as to vigorous and overly enthusiastic Soviet ones. The purpose of these cartoons was to reinforce the feelings both of class solidarity with the proletariat of capitalist countries and of hatred for American capitalism.

At the same time, America loomed large in the Soviet imagination as a country of advanced industry and technology, a standard of copious production. When in October 1961 the new Program of the Communist Party of the Soviet Union was adopted, it openly declared that for the following decade the country's goal was to "surpass the strongest and richest capitalist country, the United States, in production per head of population." The Program also promised to improve the Soviet people's standard of living, to make all collective and state farms more productive, to satisfy "in the main" the demand for housing, to eliminate hard physical work, and to give the Soviet workers the shortest working day in the world. "The majestic edifice of communism" was supposed to be erected by 1981, which would allow "everyone to live in easy circumstances" (75-76). This ambitious plan was presented to the Soviet people with great 
fanfare, and the need to catch up with and surpass America was amply illustrated in posters and cartoons (Figure 7). Soviet media constantly harped on the progress and prospects of this competition. Even the confiscatory monitory reform that took place in January 1961 and redenominated ruble at one tenth of its prior value was presented to the Soviet people as a means of stimulating production and consumption, as well as a way of strengthening Soviet currency against — predictably — the U.S. dollar (Figure 11).

During Brezhnev's years, Khrushchev's plan to build communism by 1981 was abandoned. The party's promise of economic growth became, as Christopher Read puts it, a "receding chimera" (177), leaving behind an image of America as an ideal of material prosperity, always desirable but always out of reach. By the end of 1970s, most Soviet citizens realized that the growing domestic production statistics were largely fabricated by bureaucrats and party officials. Richard Sakwa notes that in 1987 Soviet economists G. Khanin and V. Selyunin contested the official figures published by Goskomstat (Central Statistical Agency) (426), but even before their report came out, any observant person could not help but notice the decline of Soviet economy: faltering supplies of even the basic products and their poor quality, long waiting periods for government-provided housing, and deteriorating infrastructure.). ${ }^{14}$ Far from living in easy circumstances, Soviet citizens were struggling harder and harder to feed and clothe their families.

In many respects similar to the circumstances of the Soviet Union, East European countries had centrally planned economic systems and suffered from shortages of basic goods and housing, but their citizens were a little better off materially than the Soviets. Mila Grubrova, a Czech immigrant who defected in 1982, recalls how Soviet military personnel stationed near Prague after the 1968 invasion considered Czechoslovakia "the Little West" and were reluctant 
to go back home after their terms of service were over (Grubrova). Consumer goods manufactured anywhere in the Eastern bloc were of much better quality and, therefore, a lot more desirable than anything produced in the Soviet Union. Hedrick Smith notes "a certain snob appeal" of goods from Eastern Europe and Third World countries as well as the "exorbitant premiums" that the Soviets were ready to pay for them (81). I remember Wanda, a Polish cosmetics store that opened in Leningrad in the mid-1970s. In any weather, I could see- and often joined - long queues of women waiting for hours for a chance to get in and buy face lotion, lipstick, or eye shadow that were superior to anything that could be found in regular department stores. The layout of the Polish store and its smell, the design and the feel of the beauty products were a world apart from the shoddy and unappealing output of Soviet factories that could be found in Soviet stores.

Nevertheless, attractive as Polish or Hungarian merchandise might be, beyond the Little West of the Communist bloc countries lay the real West, and any glimpse of the variety of consumer goods available there was shocking for East Europeans. Marcela Cooley, a Czech immigrant who came to America at the age of thirteen, recalls how impressed she was with thick Sears and J.C. Penney catalogs that her family received from a friend who had defected to America a few years before them. She also remembers stretching for weeks every box of TicTacs that arrived in those parcels and savoring their unusual flavors (Cooley). In the early 1970s, blue jeans became hot items; not available in any Soviet stores, they were smuggled in and sold on the black market for seventy-five to eighty rubles (Hedrick Smith 251). Considering that a doctor and a kindergarten teacher made, respectively, about one hundred (Hedrick Smith 94) and eighty-five rubles a month (Shipler 59), buying contraband goods required dedication and 
material sacrifice, to say nothing about the risk of imprisonment for engaging in illegal blackmarket transactions.

Ironically, jeans and rock music in the Soviet Union resulted from the rejection not of middle-class values as was the case in America but of the austere communist ideals imposed by the previous generations. Soviet youth of the 1970s, as Hedrick Smith notes, were "the vanguard of new materialism" (237). No wonder that they turned their curious gazes towards America and developed an attitude that Hedrick Smith calls "a schizophrenic mixture of love and hate." For Russians,

America is both rival and model, the one country against which Russians feel compelled to measure themselves, the one worthy standard in the world. They may run it down as a harsh, money-grabbing country of crass materialism devoid of moral values or civic responsibility, but many—especially urban intellectuals—speak admiringly of American technology, efficiency, creature comforts—of America's unassailable modernism. (626) Although Soviet propaganda kept insisting that most Americans were too poor to afford any of the attractive goods and that only a handful of the super-rich could enjoy the much-vaunted freedoms, the evidence to the contrary was gradually accumulating.

Rare letters and pictures arriving from America also contested propaganda claims about the overwhelming poverty of Americans. Although more educated and well-informed than early twentieth-century peasants, prospective emigrants of the 1970s and 1980s displayed similar naïveté in judging the letters. Thus, Alexei Rodimtsev, a Russian immigrant who came to the United States in 1990, remembers how in the 1980s he was impressed by a letter in which his emigrant friend described a seemingly care-free and prosperous existence. The author of the letter didn't have a job and lived on welfare, but was still able to rent a separate apartment (not a 
room in a communal one) and have enough to eat. Moreover, he furnished his apartment by just walking down the street on trash day and finding everything he needed, including a TV and a refrigerator, both in working condition. Rodimtsev's inevitable conclusion was that in such a wealthy country, even the unemployed didn't have to worry about anything because many people throw away perfectly good things — which did look good in the photograph included in the letter. Another picture featured the emigrant friend in the wine isle of a supermarket, looking at the endless rows of brightly labeled bottles - a variety shocking for a Soviet citizen. Only a personal encounter with American reality would show that the wine immigrants could afford was of the cheapest kind, that their apartments and furnishings were dingy, and that the neighborhoods where they lived were dangerous and grimy (Rodimtsev). Fintan O’Toole notices similar reactions to family pictures sent from America to Ireland in the 1960s, "This is our car. This is our ice-box. This is our porch. This is our pool. That the images might be [...] illusions, merely added to their allure" (62). Even the Irish who had a free flow and a variety of information from America fell under its "tantalizing spell” (O’Toole 63), so it is not surprising that the closed world of Communist countries produced an equally strong, if not stronger, longing for an imagined America.

In addition to the economic race with America, Cold-War Communist propaganda was also trying to portray the United States as a land of political oppression where basic freedoms existed only on paper. Thus, Krasnoe Znamya published photos of American police breaking up a strike (Figure 12) and attacking civil-rights protesters (Figure 13); cartoons mocked the familiar-to-all silhouette of the Statue of Liberty and the very notion of the free world (Figures 14 and 9). Soviet press gave a lot of coverage to the tragic events of the 1960s, such as the Vietnam War and the assassinations of the Kennedy brothers and of Martin Luther King, Jr., 
touting them as proofs of American depravity. However, many reasonable people in the Soviet bloc arrived at a different interpretation of events. For example, Ivan Klíma, a dissident Czech writer, recalls a TV program he watched in New York in 1968. President Nixon appeared on TV to defend the Vietnam War and was followed by a commentator who "started to take the president to task in a manner that seemed unbelievable" to Klíma ("What We Think" 51). Such freedom to criticize the president contrasted sharply with the situation in Klíma's native Czechoslovakia, where an attempt of reform had just been crushed by the Soviet Army. Similarly, the Watergate scandal and Nixon's resignation in the mid-1970s were perceived by Eastern bloc intellectuals as a proof of the strength and vitality of American democracy. Most importantly, America was imagined as an ideal land of freedom in contrast to the grim reality of totalitarian societies, with its material deprivations and pervasive fear. Aleksa Djilas, son of the famous Yugoslav dissident Milovan Djilas, explains the warm feelings towards the United States among Eastern bloc intellectuals who "loved America because [they] feared the Soviet Union.” For them, “[t]he land of camps for political prisoners was America's beautician; its crimes and evil intentions made the wrinkles on America's face much less noticeable" (29). By the end of the 1960s, not only East European but also many Soviet intellectuals became disillusioned in communist ideals. As Robert C. Grogin points out, the brutal suppression of the Prague Spring in 1968 "seemed to destroy any vestige of belief that socialism could evolve into anything resembling a human face" and pushed the intelligentsia into a position of hostility towards the communist regimes (312). Not surprisingly, this disillusionment resulted in a wave of emigration from all Eastern bloc countries. Grubrova recalls that thousands of Czechs defected, escaping through Yugoslavia (Grubrova). According to Zaslavsky and Brym, the events of 1968 "deeply shocked [and] plunged into despondency" Soviet democratically minded 
intelligentsia, precipitating the emigration movement—ostensibly to Israel but in reality to the United States (40). Zubok notes that for the Russian-Jewish intellectuals in particular, the Soviet Union with its rising anti-Semitism and discrimination was now "a ruined utopia" rather than the "Promised Land" of the post-revolutionary years (312). During the decades of Brezhnev's rule, America became a place where one hoped to start a new life unencumbered by ideological restrictions and ethnic prejudice.

Finally, the Cold-War battles were also fought in the cultural sphere, so that intelligentsia of the Second-World countries was caught in the midst of what David Caute calls "the cultural contest between the capitalist democracies and the Communist states" in which each side tried to present itself as the most advanced in the fields of arts, athletics, and any creative endeavors (3). Both sides sought cultural supremacy to prove the validity of their respective economic and political systems. Olympic medals and ballet performances were seen as political capital, and the Soviet government went out of its way to promote award-catching activities-without letting up on its social-realism demands or ideological restrictions. At the same time, Soviet authorities were trying to keep the Soviet Union and its satellites isolated from the West and from any direct contact with Western culture, but the Iron Curtain was not as impervious as they wished it to be. Some kind of cultural and informational exchange with the outside world was constantly going on, increasing after Stalin's death and becoming more influential during the 1970s and 1980s. It was fueled, on the one hand, by the hunger for information on the part of East Europeans and, on the other hand, by the purposeful efforts of American propaganda to show life in America as one not only of prosperity but also of artistic freedom. Contrasting with strictly regimented art and literature of the Soviet bloc, cultural life of the United States was presented as an image of complete freedom of creative expression. As Caute notes: 
America $[\ldots]$ dressed its cold war shop window with avant-garde goods scarcely appreciated and rarely purchased by the large throng of shoppers within: full-blown modernism, abstract expressionism, colour-field canvases free from outside referents; buildings stripped of historical imagery, literary criticism focused on the inner life and stylistic innovation, an aesthetics resistant to social content and any programmatic element. Art for art's sake became art for America's sake. (11)

Caute refutes the well-known theory that American avant-garde art was no more than a CIA tool used as "the American cultural offensive against Soviet art" (539). Admitting the CIA role in "clandestinely promoting literary magazines, music festivals, and orchestral tours," Caute rightly notices that art and exhibits were also supported by wealthy patrons who acted on their own accord (540). The effect of American avant-garde art and music on the Soviet and East European creative intelligentsia was enormous. In the Communist countries, party apparatchiks and petty bureaucrats had the final word on what an artist could or could not exhibit and on what a musician could or could not play. Therefore, for artists and musicians suffering under the yoke of absurd restrictions, the extravaganza of painting and musical styles, which they could glimpse at occasional shows or hear on smuggled records, proved both the ultimate creative freedom and the material success of an artist in the West.

The imposition of ideological restrictions and requirements on literature and art was felt particularly sharply in Eastern Europe where a short period of independence was followed by the devastating Nazi occupation and then by the establishment of Soviet-style Communist governments. Becoming a Soviet satellite meant, among other things, that a country's literature and culture were subject to Moscow's dictate, and in the late 1940s-early 1950s it was "Zhdanovshchina," or Zhdanov's doctrine. Formulated and enacted by one of Stalin's faithful 
henchmen, the campaign sought to rid Soviet culture (and by extension Eastern bloc cultures) of Western influences and of any phenomena that did not follow the strict Party line. According to Grogin, Zhdanov "denounced Western culture as 'putrid and baneful in its moral foundations"” and charged writers and artists with the mission of inculcating communist ideology in people. When Zhdanov's doctrine was enforced in the Soviet bloc countries, Czech and Polish writers were also expected to become, in Stalin's pronouncement, "the engineers of human souls" (130). As a result, the cultural scene of Eastern Europe changed drastically. Škvorecký recalls how shortly after the war, the Communist government declared jazz to be decadent bourgeois music and how Western records disappeared from the shops, while jazz orchestras no longer played in dance halls and cafes:

Here and there, obscure little nightspots forgotten by the purifiers of social life, a last few of the Mohicans served their black masses to tiny groups of diehard aficionados. They were anonymous, and disappeared in the increasingly more oppressive darkness at noon of Stalin's last days. Soon the last nightspots were closed; the obscure midnight music makers never reappeared. They are preserved only in the fading memory of the few who remained faithful even in the times that tried men's souls (626).

However, for people like Škvorecký, who grew up on and admired American musicians and authors before the war, the impressions produced by their youthful listening and reading remained strong.

After Stalin's death and especially in the 1960s, the time of Khrushchev's "Thaw," the Soviet government somewhat relaxed its ideological restrictions, including those on selecting Western books for publication. Literary authorities now approved a wider variety of texts, as long as they were not openly anti-Soviet or anti-communist. At last, Soviet readers were exposed 
to works of William Faulkner, F. Scott Fitzgerald, J. D. Salinger, and modernist poets. Although Ernest Hemingway's extreme individualism contradicted the basic premise of Soviet collectivist ideology, his books were seen as a critique of the capitalist system and thus acceptable for publication. Vail and Genis humorously note that in the 1960s Hemingway was "the principal American of Soviet life" and influenced not only the literary but also the fashion style of the time (53). Writing in the mid-1970s, Vasily Aksenov, a writer discussed in chapter 4, also lists Hemingway as one of his favorite authors, adding that he "worships Faulkner" and, due to his ability to read in English, is also influenced by Brautigan, Vonnegut, and Albee ("Kruglye Sutki" $354){ }^{15}$

Contrary to the expectations of Communist ideologues, reading books of those American writers who were critical of the United States and exposed America's numerous social problems could not convince Soviet people in the superiority of their own socialist system. Again, readers found in the texts such details of American life that proved quite the opposite. For example, I remember a furtive discussion with a handful of close friends after an American Literature class at the Leningrad State University in the mid-1970s. Our study group had read a freshly translated James Baldwin's If Beale Street Could Talk, and the students were shocked to find out that the described black family living in what supposed to be the poorest quarter of New York resided in a separate (not communal) apartment with all modern conveniences, so that these slum youngsters could take baths at home, which was more than most students of the leading Soviet university could say about themselves. Nobody dared to draw an unfavorable comparison in class; only among trusted friends was it possible to speak up and ask the puzzling question, "If that kind of accommodation is considered a slum in America, how would our communal apartments rank there?"16 
In the 1960s, it became again permissible to write positively about America and the everyday life of its people, without bringing in the heavy artillery of communist ideology. ${ }^{17}$ During this time, critique of American mores grew more subtle and focused on personal details. Tatiana Tess traveled to the United States in 1966 on the invitation of the Women for Peace movement. Since Tess stayed in private homes, she was able to provide an account, the first in Soviet literature, of family life in America. Of course, she does devote many pages to racial discrimination, to violence against the civil-rights movement, and to President Kennedy's assassination, but she also comments on "rationalistic coldness" in the family relations in America. Here, adoptive parents do not make adoption a secret from their child; mothers are willing to send their school-age children abroad to study in the Soviet Union for a year (64); parents charge interest when they lend money to their grown-up children (143); in turn, daughters send to their mothers birthday cards with printed poems instead of personal messages (141) - allegedly the opposite of what a typical Soviet family would do. At the same time, Tess shows Americans as generous hosts and friendly, thoughtful people, emphasizing the commonality of interests between ordinary Americans and ordinary Soviets, from their love of Antoine de Saint-Exupéry's Little Prince to their desire to stop nuclear proliferation (69). Tess admits that, in spite of injustice, lawlessness, insecurity, and alienation that reign in big cities, such as New York, the picture is complex and that good people outnumber bad people there "just as in any city on Earth" (185). Tess's descriptions of American homes, of their spaciousness and comforts, made a great impression on Soviet readers. In my home town, a precious copy of this book was passed around among friends and heatedly discussed. When evaluating American living standards, Tess measures them not against those of ordinary Russians but against those of Soviet elite, claiming that "washing machines, vacuum cleaners, refrigerators have long been a 
fixture of our everyday life" and suggesting that the Soviet government should "raise the question" of manufacturing dishwashing machines that can "lighten woman's household chores" (78). Twenty years after Tess's book was published, dishwashers and even washing machines remained an unattainable dream to many Soviet women, as well as a feature in their mental picture of prosperous America.

Even in the relatively liberal atmosphere of the "Thaw," some writers, such as Andrei Voznesensky, Yevgeny Yevtushenko, Victor Nekrasov, and Vasily Aksenov in the Soviet Union and Škvorecký in Czechoslovakia, went too far in praising America and were severely reprimanded by literary authorities. Commenting on Škvorecký's writing during the decades of Communist regime, Helena Kosek asserts that "American culture was a predominant part of [his] spiritual world and was integrated into his professional world as a writer" (143). In the late 1950s, Škvorecký got into trouble with Communist literary authorities for his favorable portrayal of Americans and for his undermining of biased stereotypes about Americans (Kosek 142-143). After his 1958 novel The Cowards, he was not allowed to publish and worked as translator and editor—not surprisingly—of American fiction. Škvorecký was active in the cultural movement of 1968 and had to escape to the West after the Prague Spring was crushed by the Soviets. Reilly mentions how Voznesensky was chastised by Khrushchev himself "for failing in his duty as a writer as well as for improper comportment on his trips abroad" (65) and how Nekrasov was accused "of political immaturity and ideological indecency" (81). Soviet shestidesiatniki, or the writers of the 1960s, were by and large committed to the communist ideals, to say nothing of the lucrative membership in the Union of Soviet Writers. To restore the favor of Politburo and to maintain their privileges, they publicly repented their transgressions and promised to follow the party line in the future. Still, America remained an object of fascination and a subject of poetry 
and prose. Moreover, as Reilly observes, poets and writers who wrote about America in the 1960s manipulated the image of America "to serve as a background on which themes that relate to life in the Soviet Union are superimposed in clever and subtle ways" (xii). Since censorship did not allow direct comments on the problems of Soviet society, an idealized America became a standard of covert comparison.

Similarly to other shestidesiatniki, Aksenov displeased the Soviet literary authorities by writing stylistically experimental prose and by his "inexplicable 'fascination' [...] for the United States" (Zubok 203). In 1963, he publicly admitted his mistakes and promised to reform, which allowed him to keep publishing his books and traveling outside the Soviet Union. In 1975, he was permitted to spend two months in America as a visiting professor in the University of California at Los Angeles. By that time, Aksenov was in the vanguard of Soviet intellectuals who were shedding their Communist beliefs and the blinders of anti-American propaganda. However, he was not ready to see American reality "as is" and took a stance opposite to his literary predecessors but equally extreme. The resulting travelogue, "Kruglye Sutki Non-stop" ["Non-stop Around the Clock"], presented an uncritical, almost fantastic picture of America. The author writes about his "Typical American Adventure" (256) in rapturous tone, weaving his observations and historical digressions into a phantasmagoric picture. Readers learn not only about the visiting professor's encounters in the classroom, but also about his pilgrimages to the places where the hippie movement - a symbol of unfettered freedom — was born, such as Venice Beach and Haight-Ashbury. The narrative is full of witty snapshot descriptions - faces, clothes, ads, street signs, funny situations, fleeting impressions, associations; in the spirit of the time, it is interspersed with English words without Russian equivalents (jet-lag, folks, tough guys, beachbum, groovy, easy-going, chain-smoking) as well as with newly introduced and seemingly 
unnecessary Anglicisms (kar, air-kondishn, kampus, bilding, laif-gard). In addition, the author does not merely record his observations but also asks searching questions: why Americans despise advertisement (334); what they mean when they talk about totalitarianism (283); whether American prose has become part of Russian aesthetic tradition (357). Aksenov's attempts to answer these and other questions subvert the clichés of Soviet propaganda writing: Americans were supposed to be different from Russians and, therefore, bad; some of them were allowed to be good on the basis of common class interests (as was the case in Tess's book). Aksenov's Americans are attractive because they are different—uninhibited, individualistic, not afraid to speak their minds, critical of their government, and rebellious. In short, they are everything that the Soviet intelligentsia of the 1970s wanted but never dared to be.

That Aksenov had the courage to submit this book for publication is understandable: it was a logical step in liberating his writing from the grip of official and internal censorship, a step that led him to publishing in Italy The Burn, his novel openly critical of the Soviet system, and to participating in an unauthorized literary almanac Metropol — all of which resulted in his 1980 expulsion from the Soviet Union. By Aksenov's later admission, he knew that his uncritical view of America would drive Soviet literary authorities "up the wall," but he felt compelled to counteract the propaganda stereotypes (SMB 212-213). It is harder to explain why Aksenov's unorthodox book about America was indeed accepted and printed in the prestigious literary journal Novy Mir [New World] — until we remember that it was Novy Mir that in 1963 published Alexander Solzhenitsyn's One Day in the Life of Ivan Denisovich and his controversial short stories. After Stalin's death, Novy Mir was a bastion of what Dina R. Spechler calls "permitted dissent." In her study of the journal's 1953-1970 activities, Spechler argues that its editors Konstantin Simonov and then Alexander Tvardovsky "actively sought and encouraged 
discussion of the gravest problems confronting the regime and the society" —often provoking displeasure of Party authorities (xvi). Although, as Spechler asserts, in 1970 Novy Mir was "compelled virtually to cease functioning as a vehicle of dissent" (xvi), it remained the most daring of Soviet literary journals. It was only in Novy Mir and Inostrannaya Literatura that one would expect to find unorthodox opinions or stylistic deviations. Under the editorship of Sergei Narovchatov, "Kruglye Sutki Non-stop" came out in one of the journal's 1976 issues and became enormously popular. It fed the Soviet youth's insatiable appetite for details of American life and for the magic of the English language. At the height of Brezhnev's soulless rule, Aksenov's book invited an unfavorable comparison of the Soviet Union to the United States and dealt a severe blow to the already crumbling propaganda image of the evil America, but in doing so, it also reinforced the growing allure of the American myth and added fuel to the hidden fire of emigrant culture.

\section{Behind the Wall: Alternative Images}

Due to samizdat distribution and smuggling, East European readers became familiar with banned books, including those by emigrant writers. Among dedicated people who worked on supplying the Soviet intelligentsia with much-wanted forbidden texts were Carl and Ellendea Proffer, American Slavic scholars at the University of Michigan. In 1971, they started Ardis Publishers, a small press dedicated to printing Russian literature, specifically texts that were banned, long ago out of print, or otherwise unavailable in the Soviet Union. Ardis published, among others, books by émigré authors, such as Nabokov, Aksenov, and Joseph Brodsky. The Proffers were also personally involved in getting the books into the Soviet Union and in assisting Soviet dissident writers. In his biography of Nabokov, Brian Boyd mentions another organization focusing on publishing books for clandestine distribution in the Soviet Union-Radio Liberty. In the mid-1960s, under the imprint of Editions Victor, it published Nabokov's Invitation to a 
Beheading and The Defense (504-505). Similar to other forms of cultural production during those decades, book distribution was part of the Cold-War effort. Carl Proffer admits that many Russian classics were published with money from the CIA ("Nadezhda" 47). As a result, émigré writers became familiar to Soviet intellectuals. Assessing Nabokov's Soviet readership in 1970, Ellendea Proffer observes that "almost every person seriously interested in literature that one meets in the Soviet Union has read at least two works by Nabokov." To the surprise of "even the most well-informed watchers of Soviet literature," the forbidden émigré author has numerous admirers, "including members of 'the Nabokov cult"' (253). Boyd argues that during the 1960s and 1970s previously existing sharp division between the émigré and Soviet literature broke down because "many Soviet writers escaped censorship at home by publishing in the West and often followed their works abroad" (647). It was also because their works traveled back to the Soviet Union and obtained a strong, albeit unauthorized position among the literary texts that shaped the intelligentsia's concept of émigré life.

In Czechoslovakia, both samizdat and tamizdat flourished in the 1970s. Joseph Benatov calls this decade a period of "fervent subversive activities." He mentions both underground publishing establishments within the country, such as Ludvík Vaculík’s Edice Petlice [Padlock Editions], and numerous presses abroad, including Sixty-Eight Publishers that was founded in Toronto by Škvorecký and his wife, writer and actor Zdena Salivarová (112). Benatov also notes the contribution of Philip Roth who not only visited Czechoslovakia several times during the 1970s but also founded the Penguin series Writers from the Other Europe (113). All these efforts supplied Czech and Slovak readers with a constant stream of forbidden literature, with books by dissidents, such as Václav Havel and Ivan Klíma, and by emigrant authors—Škvorecký, Salivarová, Milan Kundera, and others. 
It is hard to assess the scope of underground book circulation, to determine the exact numbers of samizdat copies, or to estimate how many readers might have read each of them. However, all immigrants whom I interviewed affirm that these texts contributed to their rejection of Communist regimes as well as to their conception of America (Grubrova, Rodimtsev). I can add that reading George Orwell's 1984 and Hedrick Smith's The Russians became a turning point of my life. The effect of these books was similar to taking off a blindfold and being able to see the world for the first time. Forbidden books remained a significant source of information about the West until Perestroika time when censorship and restrictions on publishing were gradually relaxed and, finally, eliminated. By the late 1980s, both Soviet and East European readers could enjoy free access to previously banned texts by foreign and domestic authors.

American pop culture, which was almost stamped out in the late 1930s, became more and more of a presence in the post-war Soviet-bloc countries. It had an even stronger impact on the minds of East Europeans than samizdat and tamizdat books, in part because more people had access to it and because unlike possession of banned books, owning music records was not a criminal offense. Pop-culture images were re-interpreted and appropriated as an alternative both to the caricature portrayal of America and to the austere official culture. A brief comeback of American films occurred during the short breathing spell between the end of World War II and the onset of the Cold War. Many Hollywood films-Tarzan, Stagecoach, Mr. Deeds Goes to Town, The Roaring Twenties, Sun Valley Serenade, among others-were brought from Germany as war trophies and then distributed in movie theaters throughout the Soviet Union. Stites describes the liberating effect of their "acting styles, adventure and music" on the post-war Soviet youth (125). There appeared stilyagi, or young people who "turned foreign material culture and art, especially American jazz, fashion, and dances, into a cult" (Zubok 89). The 
culture of stilyagi developed speech patterns, style of clothes, and unconventional behavior that emulated movie characters (Stites 124-126). Through the 1950s-1980s, Soviet establishment continued its attempts both to suppress the alternative youth culture and to tame jazz into the straightjacket of official estrada music — all without success. In the 1960s, according to Stites, stilyagi divided into two trends, shtatniki (stateniks, or “Americans") who were faithful to jazz and bitniki- fans of 'beat' or rock (132-133). Similarly, Škvorecký describes the comeback of jazz in the mid-sixties Czechoslovakia, when rock replaced it as "socially dangerous" music (627). The generation of the 1970s became hooked on rock music and adopted the hippie style of clothing. Grubrova recalls her passion for Western rock and names her favorite bands and singers of the 1960s-1970s: the Beatles, Queen, Pink Floyd, Led Zeppelin, Creedence, Electric Light Orchestra, Cat Stevens, Joan Baez, and Janice Joplin (Grubrova). After the Soviet invasion of 1968, the spread of decadent Western art was among the transgressions that Moscow imputed to the delinquent Czechoslovak government, but the smuggling of coveted goods from the West continued throughout the Soviet bloc countries, including Brezhnev's Soviet Union. Hedrick Smith describes a furtive black market transaction he witnessed in a street in Leningrad and names the popular music titles of the time-Hair and Jesus Christ Superstar —along with the price, a hundred rubles per record (235). Interest in America and other countries of the West resulted in what Smith calls "astonishing pockets of knowledge about Western life," with individuals becoming well-informed in their field of interests, be it the lives of their favorite rock stars or architectural trends (627-628). Moreover, the study of foreign languages became a means not only of developing into a well-rounded Soviet citizen (a goal encouraged by the Communist Party) but also of tapping into unauthorized sources of information. ${ }^{18}$ Many young people learned English in order to understand the lyrics of rock songs, to read English-language books 
smuggled in by brave travelers, and to better appreciate the glimpses of Western life they provided.

During the Cold-War years, Western radio was an important source of information both about the West and about life in the Communist bloc countries. Voice of America and Radio Liberty targeted the Soviet Union, while Radio Free Europe beamed its programs to Eastern Europe. These stations filled in the gaps left by the selective and tendentious news coverage of the Communist media, while their cultural programs fed the insatiable appetite for jazz, rock, and forbidden literature. As Alexander Rapoport states, in the mid-1950s VOA broadcasted, among other programs, commentaries on the American economy, refuting the claims of Soviet propaganda "about the impoverishment of the working class, growing unemployment, etc." (10). Rapoport claims that VOA provided truthful information about "the disarmament proposals of the United States and its allies, always falsified by the Soviet press" (7-8). Rapoport's declaration of veracity is contested by the ideologues of anti-Soviet propaganda, such as Bogart, who in 1976 admitted that "truth comes in many shapes and forms" and recommended such techniques as "selecting from it, tempering it, or even disregarding it" (128). Still, many Soviet listeners tended to believe what they heard on VOA. Young people listened to "subversive" music on the VOA, in particular to Willis Conover's jazz programs that started in 1955 and continued almost until his death in 1996. Conover's New York Times obituary claims that during the Cold War, his six-times-a-week Jazz Hour had as many as thirty million regular listeners in Eastern Europe and the Soviet Union. Ironically, in the United States, Conover is known only to a handful of jazz experts because VOA was not allowed to broadcast its programs domestically (Thomas). Radio broadcasts often featured recent émigrés who now became a source of American imagery for their native countries. Gene Sosin, who worked for Radio Liberty from its 
inception in 1953 till 1986, mentions dozens of names, including such former Soviet writers as Sergei Dovlatov, Anatoly Kuznetzov, Victor Nekrasov, and Vladimir Voinovich who worked as broadcasters (233). Others, for example Nabokov, contributed to literary programs. Rodimtsev recalls how in the mid-1970s in Leningrad he heard RL broadcasting Nabokov's reading of Lolita (Rodimtsev). As Maria Nemcova Banerjee points out, after leaving Czechoslovakia, Škvorecký, contributed regularly to the Czech section of the VOA and "reviewed American cultural scene with scholarly competence and a sharp eye for provocative issues" (150). His programs contested the Communist propaganda claims about the depravity of American bourgeois art. Grubrova mentions Karel Kryl, an émigré Czech singer, who lived in Germany and whose political songs were broadcasted over RFE (Grubrova).

In spite of frequent jamming of the VOA, RL, and RFE programs, people listened to them on portable short-wave radios in all Soviet bloc countries. In his recent comic book about growing up in Communist Czechoslovakia, Peter Sís shows how behind a façade bristling with red flags, Czechs in their tiny private apartments are hiding under beds to read smuggled or samizdat books and lean closely to their transistor sets to listen to the jammed Western radio stations (n.p.). As Alexei Yurchak argues, these programs resulted in "a huge explosion in the popularity of Western jazz, rock and roll, foreign languages, and general knowledge about the world" (181). Apart from regular jamming, Soviet propaganda tried to discredit Western radio stations as tools of American capitalism; in some ways this assertion was correct. According to Sosin, RL was secretly funded by the CIA until 1971 "when its cover was blown and [its] raison d'être [...] was questioned" (xiv). After a long congressional investigation and debate, both Radio Liberty and Radio Free Europe were allowed to continue "with overt funding" directly from the U.S. Congress (147). Not surprisingly, as Zubok points out, RL and other Western radio 
stations "played sometimes idealized expectations about American and Israeli society to those who were disillusioned with the Soviet experiment [... and wanted] to belong to a democratic Western culture, to be part of Western civilization" (313). The Soviet government's efforts to curb the influence of Western radio broadcasts failed, and by the end of the 1970s, what was supposed to be "enemy voices" was perceived as the most reliable source of information about life on both sides of the Iron Curtain, exerting a strong influence in Communist countries, especially in the circles of potential emigrants.

The 1970s under Brezhnev's rule became known as a period of stagnation-both economic and cultural—when cynicism and hypocrisy permeated all levels of Soviet society and when many people in the so-called "creative professions" turned their backs on the official Soviet culture. They retreated into "internal emigration" - an underground world of alternative culture, of samizdat literature, and of secret rock concerts and art shows. This lifestyle allowed its practitioners both to take advantage of the socialist system and to "actively reinterpret cultural parameters of that world" (Yurchak 132). Not surprisingly, many Soviet intellectuals looked up to the West, especially to the United States, for ideals and used all possible sources of information to satisfy their curiosity. From being the major, often the only provider of American imagery, the official propaganda was pushed aside as tendentious and unreliable. Yurchak rightly notes that during the 1950s-1980s the attitude of Soviet authorities towards different forms of foreign culture was ambiguous and open-ended, as “jazz, radio broadcasts, fashion, film, language, rock music [...] were simultaneously critiqued and promoted, attacked and allowed to develop." As a result, "the Imaginary West had become an indivisible and constitutive element of late Soviet culture" (165). It also became an object of desire, replacing any vestiges of communist ideals promoted by the culture of previous generations, such as asceticism, personal 
sacrifice, and heroic labor for the welfare of the socialist motherland. Although the majority of Soviet citizens continued paying a lip service to the tenets of communist ideology while pursuing new materialistic goals and enjoying the fruits of forbidden arts, others decided to follow their dream to its source and start their lives afresh in America.

\section{After The Wall}

In the early 1990s, when Soviet and then Russian citizens started to travel freely, the long-existing trend of measuring Russia up against an ideal America culminated, only to be reversed by the end of the century. Olga Mesropova contrasts two travelogues published in Russia in 1992 and 2000. Mesropova asserts that the former, Coming Back, Travel Notes as if About America, by a famous satirist Mikhail Zadornov is inspired by the "pro-American euphoria of the early 1990s" (27). Zadornov writes with sarcasm and bitterness about Russia whose standards of living and everyday culture compare unfavorably to those of America. Like his predecessors, Gorky and Mayakovsky, he uses hyperbole, but this time it is the prosperity and abundance of America that is exaggerated. Mesropova quotes Zadornov's description of an American supermarket that carries "forty different kinds of cheese, thirty-seven types of olives, and ninety brands of yogurt" (29) —an overkill for the purpose of impressing the starved Russian consumers of the early 1990s when shelves in Russia's grocery stores were practically empty. Even worse than the inflated numbers is Zadornov's assurance that all Americans are wealthy enough to decide casually whether they want to travel to the Bahamas or to Italy, to buy a villa or a new car (qtd. in Mesropova 30). It is no coincidence that at the peak of this adoration of America, the emigration wave also crested. Zubok notes that in 1988-1993 1.5 million people left Russia, driven out by the fear of Russian fascism and "the collapse of the cultural and scientific infrastructure" (355). Coming out at a frightening turning moment in Russian history, Zadornov's book must have pushed many desperate Russian citizens towards emigration. 
However, by the end of the century, America no longer stood flawless in Russian literature. In Igor Svinarenko's Moscow Across the Ocean, the comparison of the two countries and cultures continues, but the author's sarcasm is directed towards America's parochialism and lack of sophistication. In the worst tradition of Soviet ideologues, Svinarenko starts with a faulty premise: he visits several small towns in the United States that are named Moscow and compares them not to Russian towns of similar size but to the capital of Russia. Naturally, the offerings of county public libraries and the cultural life of semi-rural areas lose the competition. Unlike Zadornov's globe-trotting Americans, people who live in Svinarenko's Moscows have never traveled far from home - not even to New York City, to say nothing of Europe. Mesropova points out that Svinarenko's travelogue exemplifies "the new wave of Russian cultural antiAmericanism" that is prevalent in Russia today (36). Mesropova attributes this change of attitude to "the effect of the pendulum" (36), but the reasons might be more complex.

Stephen Brooks quotes Vladimir Shlapentokh's assertion that post-Communist Russian elites are strongly, even pathologically anti-American. Among the reasons for such negative attitude, Shlapentokh lists a desire "to rationalize their [the post-Soviet elites'] failure to build a 'normal' liberal society" as well as the need to justify their "deep involvement in corruption and criminal activities"; he also stresses the functional role of today's anti-Americanism that is based on distorted images of America (qtd. in Brooks117). In addition, the collapse of the Iron Curtain brought about not only political changes but also an abundance of Western consumer goods and cultural products. Commenting on Russia's cultural scene of 1992-1993, Nancy Condee and Vladimir Padunov assert that traditional high culture was displaced and marginalized by "a flood of cheap American action movies," a domination of Western plays in the theaters, and "a proliferation of European and American television and radio broadcasts" (140). Moreover, 
pornography, which was practically unheard of in the Soviet Union, became firmly established on the post-Perestroika Russian market (152). Nevertheless, high culture remained a standard of comparison in Russia so that when Russian consumers became suddenly exposed to the worst samples of Western mass culture, they compared them to nineteenth-century "immortal" classics rather than to low-brow domestic entertainment. Helena Goschilo notes "Russia's peculiar penchant for ideological legitimization through 'high' art," in particular a tendency to idolize Pushkin (81). American cultural production is now overwhelmingly represented in Russia by soap operas, violent action movies, and pornography, but it still has to compete with Pushkin and Tchaikovsky. Consequently, the United States can be declared an "uncultured" country. Svinarenko's travelogue might be both a reflection of this disappointment in America that ordinary Russians experienced in the 1990s and an ideological tool similar to the books of his Soviet-time predecessors. Although people still look at books for opinions on the United States and emigration, unbiased accounts of America remain as rare in the beginning of the twenty-first century as they were during the Soviet time.

What image of the West and of the United States was created by all these disparate pieces of information? To counterbalance the official propaganda picture of America as a place of exploitation, violence, and economic hardships, émigrés were constructing an alternative image that concurred with the parameters of the American Dream: a technologically advanced country with enough wealth to go around and to provide even ordinary people with comforts unimaginable in the Communist bloc; an entrepreneurial culture that offered opportunities for fame and material success; a political system that guaranteed political, religious, and artistic freedom. Although considerable evidence did indicate that Western societies had their share of 
social problems and that life of fresh immigrants was not easy, the sum total of the data was imagined rather than calculated. Having been brought up on binary Marxist formulas, most East Europeans could only see East and West as two opposites. When they became disillusioned in the communism promise of equality, freedom, and prosperity, they simply reversed the equation, attributing all the good qualities to the West and all the bad ones to the Soviet bloc. This dichotomy is best illustrated in Sís's comic book that contrasts the two worlds divided by the Wall: the Eastern bloc is grey, marked by such epithets as stupidity, suspicion, injustice, terror, fear, envy, corruption, and lies. On the other side of the Wall lies a pink landscape, inscribed with words hope, justice, inspiration, integrity, liberty, joy, dreams, respect, dignity, truth, freedom, wisdom, love, benevolence, spirit, morality, virtue, honor, pride, art, trust, happiness, knowledge, and equality. Beyond this paradise, over which the author flies on rainbow-colored wings, and beyond the blue ocean, looms the silhouette of Manhattan with the Statue of Liberty — the pinnacle of dreams and desires (n.p.). Hundreds of thousands of emigrants rested their hopes on this place.

This imagined America was a fabulous land where anything was possible. It was associated with many kinds of freedom denied to people in the Communist bloc. As Klíma puts it:

It was a great encouragement for me to know that there existed an entire continent where one could live freely, where they didn't jail people because of their attitude to the regime, where they didn't confiscate books or ban authors and where they didn't expel professors from universities for rejecting a totalitarian (or any other) ideology. ("What We Think" 52) 
Americans take for granted these freedoms (or argue that they are illusive), but this radiant vision of free America supported East Europeans during the darkest time and inspired many of them to emigrate. In their dreams, America was not only an abstraction but also a place with certain physical characteristics, a land of endless variety of consumer good, of spacious and luxurious houses, of superb roads and powerful cars. Recalling his childhood in Communist Yugoslavia, Djilas says that all things that reminded him of America were beautiful— "the colour light-blue, ice-cream, birthday parties, the new swimming pool in [his] neighbourhood, a tall tree with smooth bark in [his] yard that [he] liked to climb" (27). Many people, both those who left and those who stayed, developed a connection to this imagined place.

Communist propaganda was partially responsible for the wide-spread fascination with America. By keeping the United States in the spotlight and providing a constant stream of information about it, no matter how distorted, Soviet media created an unassailable America ideal. Communist societies became gradually westernized, acquiring consumer goals, cultural expectations, and artistic tastes similar to those of West Europeans and Americans. Yurchak argues that although elements of Western style and culture were not incompatible with the system of dominant discourse of the Soviet bloc, "the development and further spread of the imaginary worlds within the fabric of socialist society gradually changed the very cultural logic of the Soviet system, deterritorializing it and rendering it increasingly incongruous with the description it made of itself," thus contributing to its collapse in the late 1980s (204-205). This is certainly true, but in the 1970s and early 1980s, when nobody could have predicted the approaching end of the Soviet system, this Imaginary West also became an incentive for emigration. 
It is beyond the scope of this project to determine why, other things being equal, some people firmly resolved to remain in their country whereas others chose to ignore the negative information, to believe a different myth, and to follow a different dream. Rather, the goal of subsequent chapters is to analyze the texts of several émigré authors and to find out how the place they encountered measured up to their particular ideal. Most of the writers selected for this project grew up in Communist countries and were influenced by the factors described above. The exception is Mary Antin, who lived in and left behind a world drastically different from the postWorld-War-II Soviet Union and Eastern Europe. Her connection to the other authors inheres in the immigrant experience as well as through the literary model that she helped to establish.

\footnotetext{
${ }^{1}$ The entries in this list are arranged in the order of decreasing permissibility and increasing danger associated with their use. Possession of banned books was considered anti-Soviet agitation and propaganda and could result in a prison sentence of six month to seven years or an internal exile of two to five years ("Zakon").

${ }^{2}$ We now take for granted the fact that after World War I Russian and Austrian-Hungarian empires disintegrated, giving way to, among other countries, independent Poland and Czechoslovakia. However, in 1918, the fate of these nations was not at all certain and depended to a great degree on America. According to Herbert Adolphus Miller, the winning Entente powers - Britain, France, and Italy — were ready to follow the policy of the United States (78). Although President Wilson originally favored the preservation of Austria-Hungary, he (as well as the American public) was won over when Professor Thomas Garrigue Masaryk, later the first president of Czechoslovakia, spent several months in the United States, meeting with journalists
} 
and politicians and spreading the word about the desire of Central European nations to be independent. The memorandum he sent to President Wilson was based on the principle of selfdetermination of nations that had been recently formulated by Wilson (75). After Wilson expressed his support for the creation of Poland, Czechoslovakia, and Yugoslavia and even sent a small American expeditionary force to aid the Czechoslovak army, Masaryk wrote, "Your name, Mister President, [...] is cheered in the streets of Prague. Our nation will be forever grateful to you and the people of the United States" (79). This image of America as the bastion of freedom and a benevolent superpower remained engrained in the Czech and Slovak cultural memory.

${ }^{3}$ Here are some examples of memoirs and fictionalized biographies in which the authors describe their childhood and youth in tsarist Russia as well as their émigré experience: Anything Can Happen by George and Helen Waite Papashvili (1945), Marie Avinov: Pilgrimage Through Hell by Paul Chavchavadze (1968), Kyra's Story: Reminiscences of a Girlhood in Revolutionary Russia by Kyra Karadja (1975), Windows on the River Neva by Paul Grabbe (1977), Tania: Memories of a Lost World by Tania Alexander (1987).

${ }^{4}$ The former was, of course, not real book printing but copying texts on personal typewriters, on photographs, or even by hand.

${ }^{5}$ Brook Farm was a utopian agricultural commune that existed in Massachusetts in the 1840s. Its founders (Nathaniel Hawthorne among them) were inspired by Transcendentalism and by the philosophy of the French socialist Charles Fourier.

${ }^{6}$ For example, Boris Pilnyak’s “Okay, Amerikansky Roman” [“OK: An American Novel”] (1931) leans towards condemnation. 
${ }^{7}$ The Russian title of this book is Odnoetazhnaya Amerika [One-story America], which reflects the authors' observation about the prevalence of small towns and single-family homes in the United States, contradicting the popular picture of America as a country of sky-scrapers. The English title for the 1936 American publication was echoing the title of Ilf and Petrov's previous book, The Little Golden Calf, the translation of which was published in New York in 1932. ${ }^{8}$ According to Karen L. Ryan, at the time of Ilf and Petrov's return from America (1936), the atmosphere in the Soviet Union was "growing increasingly repressive and xenophobic" and attacks against such cultural figures as Dmitry Shostakovich, Vsevolod Meierkhold, and "formalist" writers were beginning. Ryan notes that all Soviet-time editions of Ilf and Petrov's travelogue $(1936,1937,1947,1961,1966)$ "vary substantially [because] the text was unusually subject to political exigencies" (264-265).

${ }^{9}$ For example, in her 1966 book, a Soviet journalist Tatiana Tess writes with veneration about her visit to Mark Twain's house in Hartford. She declares the immortality of Mark Twain's characters and is rendered speechless when a young reporter asks her whether she has read Mark Twain's books (61).

${ }^{10}$ Whereas the term the third Rome circulated in pre-revolutionary Russia, the fourth Rome is a term coined by Clark and not used in the Soviet Union (2).

${ }^{11}$ Incidentally, Carl Proffer notices the same tendentiousness in American publishers and critics who are not interested in books by Soviet authors unless they have a "dissent angle." He asserts that "in both countries the authors' socio-political stance is far more important than how he writes - thus they have Dreiser and we have Solzhenitsyn" (Preface xviii).

${ }^{12}$ The electronic catalog of Russian National Library lists four editions of Karl May's books for the 1890s and forty-three for the 1990s. His books were not published in the Soviet Union 
presumably because he was one of Hitler's favorite authors. The only Russian-language edition during the intervening decades came out in 1934 in Estonia, then an independent country (Rossiyskaya Natsionalnaya Biblioteka). According to Hana Pichova, May's books remained popular in Czechoslovakia throughout the twentieth century.

${ }^{13}$ Although the Berlin Wall was not erected until August 13, 1961, I use the image of the Wall metaphorically to signal the post-World-War-II division between the First and the Second Worlds.

${ }^{14}$ For example, Khanin and Selyunin claimed that in 1971-1975 the average annual economic growth was 3.2 percent rather than 5.7 , declining to 1.0 and 0.6 during the following two fiveyear periods, not to 4.2 and 3.5 as declared by Goskomstat (qtd. in Sakwa 426).

${ }^{15}$ Although the list of American authors published in the Soviet Union in the late 1950s-early 1980s increased dramatically by comparison with the previous decades, books by "classical" or left-leaning American authors kept coming out in great numbers, whereas modernist and controversial texts did not circulate widely. If the plot and characters of a book could not be forced into a good-versus-bad (or rather "progressive"-versus-"reactionary") dichotomy, the book was published in a small number of copies. William Faulkner is a good example of such an ambiguous author. According to the General Catalog of the Russian National Library, his books started to appear in the Soviet Union only in 1958. By the mid-1980s, there were about sixteen different editions, mostly collections of stories or his more realistic novels, such as The Town, The Hamlet, and The Mansion. Although The Sound and the Fury was translated in the early 1970s and published in the literary journal Inostrannaya Literatura [Foreign Literature], it didn't appear in book form until 1985 as part of Faulkner's first and only six-volume collection printed in 100,000 copies. The total number of all books by Faulkner available to Soviet readers 
during this period was about 2,500,000 copies. By contrast, the catalog includes four twelvevolume collections of Dreiser's oeuvres published between 1929 and 1973, with the number of copies for the post-World-War-II editions ranging from 75,000 to 375,000. For the late 1920searly 1980s, the catalog lists twenty-three separate editions of Dreiser's An American Tragedy, a highly-prized exposé of the depravity of capitalist society. Most post-war editions were printed in hundreds of thousands of copies, so that the total number of just one of Dreiser's books circulating in the Soviet Union in the 1950 s- 1980 comes up to a staggering 4,350,000. There were, of course, numerous editions of his other novels (Rossiyskaya Natsionalnaya Biblioteka). As a result of such policies, complex and ambiguous texts by Western authors remained rarities, something that Communist ideologues did not want to cultivate. What they did cultivate was any books, either by American or by domestic authors, that could be used as anti-American propaganda. Many of these texts were widely disseminated and included into high-school curriculum.

${ }^{16}$ At this time, most Soviet people lived in communal apartments and shared kitchens and bathrooms with other families. Basile Kerblay quotes the 1964 housing statistics for urban population of the Russian Federation: $57.3 \%$ of working-class families lived in a single room and $20.6 \%$ in two rooms (62). Although $70 \%$ of rural population lived in owner-occupied houses and electricity was "almost universal," running water was "still generally limited to a communal pump in the street." In 1972, 48\% of rural families in Novosibirsk region were still fetching their water from a well or a river (102-103). Writing in the early 1970s, Hedrick Smith describes his shock at witnessing "peasant women doing their wash by hand in the fresh cold water of country streams" - a mere ten miles from the Kremlin (269). 
${ }^{17}$ A decreasing of hostility towards America can be observed in the following travelogues: written during the height of the Cold War N.N. Mikhailov and Z.V. Kossenko's Those Americans, A Travelogue (1960) and a product of détente, Boris Peskov and Vasily Strelnikov's Zemlia Za Okeanom [The Land Beyond the Ocean] (1975).

${ }^{18}$ In May 1961, the Council of Ministers of the U.S.S.R. passed a resolution to improve foreign languages instruction in the system of secondary education. Local school authorities were charged with a task of teaching students conversational and translation skills, with the objective of reaching the ability to read a foreign-language text without a dictionary. To accomplish these goals, authorities were instructed to start teaching foreign languages at a lower grade level, fifth through tenth grade in the majority of schools (there were ten grades in Soviet schools). In selected schools, foreign languages were to be taught starting the first through tenth grade, with some science and social science subjects also taught in the foreign language ("Postanovlenie"). I am one of the numerous Soviet children of the 1960s who benefited from this resolution, attending such a "foreign language" school and mastering English at an early age. I also know first-hand how the skills the Party wanted us to use in its propaganda war against the United States were appropriated for pushing the boundaries of the permissible knowledge and for feeding the fascination with everything American. 


\section{CHAPTER 2. MARY ANTIN TAKES POSSESSION OF AMERICA}

In the year 1891, a mighty wave of the emigration movements swept over all parts of Russia, carrying with it a vast number of the Jewish population to the distant shores of the New World - from tyranny to democracy, from darkness to light, from bondage and persecution to freedom, justice and equality. (FPB11)

In her first book, From Plotzk to Boston (1899) and in her famous autobiography, The Promised Land (1912), Mary Antin offers an idealized portrait of America at the peak of an emigration wave that swept Eastern and Southern Europe. ${ }^{1}$ During the decades roughly framed by Antin's arrival in America (1894) and the publication of The Promised Land (1912), the ranks of newly arriving immigrants were soaring. According to Molly Crumpton Winter, "over 10 million immigrants from southern and eastern Europe came to the United States; about one-third of them were Jewish" (31). One among many newcomers, Antin became the most famous of immigrant autobiographers. As William Boelhower points out, the same early decades of the 1900s saw a "proliferation of immigrant autobiographies" that did not become part of mainstream literature, "if they were considered literature at all." Because of the monocultural paradigm that dominated American literary studies of the early 1900s, these texts were "classified as non-texts [...and] buried in the 'black holes' of the American cosmos" until the multicultural model began to gain interest in the 1960s (17-18). Literary scholars brought back from oblivion such names as M. E. Ravage, Jacob A. Riis, Constantine Panunzio, Edward Bok, and many others. In contrast to other immigrant autobiographies, Antin's story of becoming 
American met with immediate success and remained popular for several decades after the publication.

The Promised Land appropriates for early-twentieth-century immigrants an American tradition of constructing an identity through an autobiographical act. The author's intent of persuading the audience determines her selection and interpretation of autobiographical facts, making the book a polemical text that joins the immigration debate and speaks in defense of the open-door policy. Antin's story of dreaming about America, of her arrival and successful Americanization, establishes continuity between previous and new generations of immigrants and contests the wide-spread belief that natives of Eastern Europe are incapable of assimilation. Antin's proclamations of a priori American patriotism resonated with the reading public and ensured the book's success, but its enthusiastic tone can barely conceal the author's traumatic immigrant experience. Moreover, information from Antin's private letters supports this more sober interpretation of the text, contesting the autobiography's claim of smooth and painless assimilation.

Examination of Antin's autobiography illuminates the link between the American Dream and place-connectedness. In Russia, Antin had a vision of America as a land of fabulous riches and opportunities as well as a place free of discrimination. The spirit of the time demanded from immigrants a rejection of the old place and a proof of assimilation, which is why, despite the hardships that her family has to face on arrival, Antin is striving to maintain her dream of America as an ideal place. Antin announces an immediate attachment to Boston, but expresses an ambiguous attitude towards the slums where she and her family reside. By declaring a connection to public spaces (schools and libraries) that promise success through education, Antin, in effect, signals continuing placelessness and alienation. Contrary to the prevailing 
environmental determinism of the time, Antin presents her encounter with America in the light of her transcendentalist convictions: both unique and representative, her story is meant to prove an individual's triumph over the detrimental circumstances. It is, indeed, Antin's individual intellectual achievements rather than her father's enterprises that lift the family out of poverty, but the book resists the need to admit that facts contradict the common immigrant belief in the America of endless opportunity and easy prosperity. Although Antin's narrative builds up to a crescendo of Emersonian unity with nature, history, and the author's new place - her "latest home [that] invites [her] to a glad new life" (PL 364), "home" remains an abstraction without any ties to a physical place. Antin's autobiography demonstrates that immigrants can neither reject and discard the old place nor achieve connection to the new place by a declaration.

\section{TAKING A STAND IN THE IMMIGRATION DEBATE}

Appearing at the height of the early twentieth-century immigration wave, The Promised Land, according to Werner Sollors, received enthusiastic reviews and a "remarkable" welcome in public libraries and educational institutions. Special editions of the book, with teacher's manuals and student questions, were "used as a public school civics class text as late as 1949" (Introduction xxxi-xxxii). In the foreword to the 1969 edition, Handlin notes that during these decades of fame, the book sold nearly 85,000 copies in 34 printings (v). Apparently, readers and scholars seemed to be taking at face value this tale of a triumphant immigrant journey, the trajectory of which Antin outlined in the passage that opens this chapter. As Susanne Shavelston notes, "[f]or many readers the text came to represent the immigrant experience" (164) — as well as a typical American one. Nancy K. Miller observes that "The Promised Land, with the Statue of Liberty on its original and current cover, embraces immigration as the deepest meaning of America." Miller is even "tempted to call it [...] a 'national autobiography,' to the extent that America's story about itself is a story of coming to America" (323). Indeed, early American 
autobiographical texts were written by immigrants. Daniel B. Shea traces the beginning of Anglo-American autobiography to John Smith and Thomas Morton who had to "project an English identity [...] against the language and behavior of the native culture" (30). These texts, as well as spiritual autobiographical writing of the Puritans, laid the basis for the concept of America and Americanness.

Autobiographical writing remained an important means of constructing an American national identity. As Sidonie Smith and Julia Watson argue:

Autobiographical narratives, their citation, and their recitation have historically been one means through which the imagined community that was and is America constitutes itself on a daily basis as American. As one potent means of testimony through which identities are constituted and critiqued, autobiographical storytelling has played a major role in the making of Americans and the making, unmaking, and remaking of 'America.' (4)

During the 1800 s, in spite of the growing numbers of newcomers to the country, Americanness was separated and often contrasted to the immigrant identity. By the time of Antin's writing, the foundational myth of the nation was not only well established but also claimed and guarded by the descendants of previously arrived European settlers. Stories of American lives were those of growing up in America rather than of coming to America. Thus, immigrants, the backbone of the nation's growing economy, were excluded from its nation-building narrative. The marginalization of ethnic stories created a rift between the dominant monocultural paradigm and the increasingly multicultural make-up of American population. As a result, Paul John Eakin asserts, at the turn of the twentieth century "the American self was undergoing a crisis of redefinition $[\ldots]$ precipitated in no small part by the very presence of the aliens who tried to 
embrace it" (Introduction 9). Why is it that in this time of xenophobia and hostility towards immigrants, Antin's claim to American identity was met with enthusiasm?

In her autobiography, Antin directly responds to nativists and acts, according to Stephen G. Kellman, as "a cheerleader for the massive immigration that was dramatically reshaping American demographics on the eve of World War I" (151). Although the xenophobic rhetoric of the time deemed the alien incapable of assimilation, readers and critics responded positively to Antin's story of becoming an American. Commenting on the reviews that appeared in the press after the publication of The Promised Land, Allan Mazur suggests that in their subtext Antin is regarded as "a member of an exotic tribe [who] has learned English marvelously well and explains in a sympathetic way the strange habits of her people" (152). Moreover, this remarkably articulate alien extols the virtues of her new country, contrasting it to the oppressive and restricted place of her origin.

Antin's autobiography proved the assimilation potential of immigrants and addressed anxieties and self-doubts of Americans. Handlin observes that in the aftermath of the intense industrialization and of the Spanish-American War, "[a] pall of concern clouded the underlying optimism of the nation" (v). Handlin further argues that Antin's book provided Americans with a much-needed reassurance and "tied the legacy of their past to the present and future. It recalled the Emersonian optimism of an earlier age, reminded them they had all once been immigrants, and refreshed their hopes about the potentialities of their society" (xii). In her autobiography, Antin asserts that America needs immigrants as much as immigrants need America:

The public school has done its best for us foreigners, and for the country, when it has made us into good Americans. [...] You should be glad to hear it, you born Americans; for it is the story of growth of your country; of the flocking of your brothers and sisters 
from the far ends of the earth to the flag you love; of the recruiting of your armies of workers, thinkers, and leaders. (PL 222)

Antin is using the language of familial relations to emphasize the immigrants' right to come to America; she is also staking out the immigrants' claim to a variety of social positions - not only among the working class but also in the intellectual circles and the ruling classes.

In addition, Antin is trying to redeem the immigrant city as a truly American place. A year before Antin arrived in the United States, Frederick Jackson Turner famously announced the disappearance of the frontier. Boelhower argues that Turner's claim "both pulled the rug out from under the model American self and unmanned the Constitution of the United States," sending Americans into a state of a "psychic shock" and compelling them "to re-ask the old question 'what is a true American." Boelhower points out that the city in those days was seen as "the geographical stronghold of the immigrant" and that, consequently, "a true American was most likely not an urbanite" (14). The contrast between the city and the country, which was so sharply felt in the early 1900s, actually had a long previous history. Tuan traces it back to the nineteenth century's "desire to combine $[\ldots]$ the antithetical images of an urban empire and an agrarian nation." Tuan quotes Emerson's chagrin that he cannot have both "rural strength and religion for [his] children [...] and city facility and polish.” Tuan believes that this dichotomy demonstrates "profoundly ambivalent and even contradictory elements" of the American Dream (196). Not surprisingly, the pursuit of the American Dream that brought millions of new immigrants to America also widened the rift between city and country dwellers, between urban and rural, or "truly American," values. Boelhower notes that, because immigrants often "preferred to remain in the cities," this concentration of newcomers made the cityscape "the dominant landscape" and turned the city into "the most conspicuous home of the foreigner." As a 
result, urban values now became almost "synonymous with a non-Anglo-Saxon point of view" (12-13). As the Western frontier was pushed to its physical limit, the immigrant city became the new wild frontier where the fate of the nation seemed to be decided.

The immediate success of Antin's book proves that her message struck the right note with American readers but was not understood in its full complexity. Writing in 1917, Mary Rosetta Parkman called it "an absorbing human story [...whose author] strives to quicken in others a sense of their opportunities and responsibilities as heirs of the new freedom [... and] pleads for a generous treatment of all those whom oppression and privation send to make their home in our land" (207). However, Antin's appeal did not stop the change in immigration laws or end the public's hostility towards immigrants. In the 1920s, the country did adopt restrictive laws that drastically reduced the number of new arrivals. Pyon Gap Min quotes the drop in immigration from $8,795,000$ in the first decade of the century to $4,107,000$ in the 1920 s and to the meager 549,000 in the 1930s. Furthermore, the share of immigrants from Southern and Eastern Europe shrank from almost $70 \%$ in $1901-1910$ to just over $27 \%$ in $1930-1940$ (4). This data explains the decline of public interest in immigration problems and signals a loss of potential audience for Antin's book. With these changes in society, the popularity of Antin's autobiography gradually waned. Mazur argues that it happened in no small part due to Antin's archaic "florid" prose style and to the general focus among immigrants on assimilation rather than on origins. As Mazur puts it, "American Jews at that time cared little about where they had been, only where they were going” (460). Antin's book was next published in 1969 when a new interest in ethnic roots emerged. Still, in 1986, Mary V. Dearborn wrote that Mary Antin’s name was “found far more often in the indexes of history books than in books of literary criticism, and the title of her novel [was] even more rarely found" (37). The very qualities that resonated with the 1912 readers did 
not appeal to the late-twentieth-century Americans. According to Dearborn, Antin had "thoroughly internalized the dominant culture's vision of the ethnic and the foreign" and her autobiography "lacks any alternative, protesting voice" (42). Such criticism charges Antin with want of complexity but continues to take her success story at face value, missing the gloomy undercurrent of her narrative.

Close reading of Antin's autobiography demonstrates that the author's journey is not of a triumphant veni, vidi, vici kind - in spite of her attempts to present it as such. In recent years, scholars started to question and contest what Shavelson calls Antin's "unified tale of smooth assimilation" (162). Winter asserts that Antin's book has "other dimensions [...] that belie her claim that the process of assimilation is ever easy or complete" (33). Similarly, Jolie A.Sheffer notes:

This paradigmatic assimilation narrative $[\ldots]$ contains within it a counternarrative revealing the terrors of immigration and the difficulties of adjusting to American life. Far from being a simple celebration of nationalist clichés, Antin's autobiography is a record of a particular form of historical and psychological trauma that has been all but forgotten in the age of celebratory (and even critical) multiculturalism. (142)

In the era that pre-dates multiculturalism, the need to prove her and other immigrants' right to follow their American Dreams motivates Antin's effort to conceal the trauma behind an enthusiastic façade, to elude any mention of anti-Semitism or hostility, and to proclaim an immediate attachment to American places.

\section{DREAMING ABOUT AMERICA}

The paradigm of immigrant narratives has been defined by Boelhower who asserts that immigrant autobiography starts with contrasting Old World to New World, closed space to open 
space, poverty to wealth, static condition to opportunity, despair to hope, oppression to freedom, racial discrimination to racial equality (42). Structurally, Antin's narrative seems to follow this pattern, starting with a detailed description of Polotzk. Antin tracks her unfolding realization of the cultural and legal status of her community in the Russian Empire, talking with indignation about the "madness" of the world where Jews and Gentiles viewed each other "as if a different species of beings" (PL 23). The tsar's discriminating policies restricted the rights of Jews and set them apart from the rest of the population, making it easy for Antin to present emigration as a natural choice for Russian Jews who do not have a country of their own:

Where had been my country until now? What flag had I loved? What heroes had I worshipped? The very names of these things had been unknown to me. Well I knew that Polotzk was not my country. It was goluth-exile. (PL 226)

Such declarations lead Elżbieta Rokosz-Piejko to assert that for Antin, "Polotzk and the Russian Pale very quickly become places rejected, belonging to the suppressed past" (174), but this statement is hardly supported by the attention Antin gives to Polotzk-almost half of the book's pages. Moreover, Antin's descriptions of place do not always confirm the contrast between the old and the new: despite the legal restrictions, Russia is portrayed as an idyllic place to which Antin is still emotionally attached.

Far from rejecting her hometown, Antin relishes the details of her childhood places and family life — a family that provided her with a "comfortable sense of being well-off" (PL 75) due to a prosperous store that her mother inherited. Antin recalls having "everything [they] needed and almost everything [they] wanted" in terms of material possessions (PL 75). The Antins live in a spacious house with a family wing and a wing "set apart for business." The house is open "for out-of-town customers to stay overnight," as well as for numerous cousins, aunts and 
friends. A cook, a nursemaid, and an outdoor man help Antin's mother take care of her four children, cows, horses, and numerous guests (PL 66-67). Family wealth is most apparent on Friday evenings when the table "gleamed with spotless linen and china [...and next to] the Sabbath loaf covered over with a crocheted doily [...] stood the wine flask and Kiddush cup of gold or silver" (PL 72). The house stands in the shadow of "an imposing edifice" of a military academy (PL 81) but is also close "to the limits of Polotzk to the fields and woods" (PL 83). Antin relishes her memories of pastoral scenes encountered on the long walks with her father: sunny dusty roads, the rustling of long grass, the cool grey interior of a peasant house where they stop for a drink of water, and a plowman singing "a rude [...] song" (PL 84-87). In contrast to the restrictions imposed on the Jewish community by the law, nature brings Antin in touch with "eternal, divine life [...that] flowed in and out of [her] fully, freely, as the river flowed and parted about the bridge piles" (PL 86-87). Polotzk and its surroundings are presented in the book as a picturesque place where the author, in spite of the oppressed status of her people, had a happy childhood.

Although Antin's goal is to contrast America's freedom to the restrictions of the Pale, she describes her native town with love and pride. On the one hand, Antin is critical of the life of the Jewish community that is surrounded by "the wall of extreme separateness between [the Jews] and the Gentiles," and in which women occupy a "medieval position" of subordination and inferiority (PL 111). Luckily for Antin and her sister, their parents "adopted the notion of a liberal education" (PL 112) and allowed their daughters to study with private teachers—until "a long series of troubles" and illnesses "reduced [the family] to a state of helpless poverty" (PL 77). These hardships eventually lead to the family's emigration and to new educational opportunities for Antin. On the other hand, as Sheffer rightly notes, the Polotzk chapters of the 
autobiography "establish the role of place in shaping community identity and belonging" (152) in particular by describing Jewish traditions. The life of the small town is locked within a circle of religious celebrations and collective seasonal activities in which everyone has a place determined by age and gender. Antin reports a variety of joyful communal rituals, such as gender-segregated bathing in the Polota River or the use of public hot baths where women "were accustomed to see each other naked" without any embarrassment (PL 89). These descriptions show a life of idyllic simplicity where there are "no germs" and no harm could be done by dipping into a common bath with standing water that "does not look nor smell fresh" (PL 97). Although Antin does not admit it in her book, emigration for her results in the loss of community.

Antin's private letters help us discern the emotions behind the rhetorical persona of her published writing. Thus, in a February 24, 1899, letter to Israel Zangwill, Antin writes about the day of Purim and laments the loss of Jewish tradition. She also voices her frustration with the American way of life:

Thinking over the happy times we had in Russia, in the observance of our beautiful holidays, makes me feel more than ever the folly of throwing aside such precious traditions, if nothing more, for such mistaken ideas of intellectual freedom as always take their place. I emphasize ideas, because that is all it amounts too. Four years have been enough to prove to me that we only become the slaves of all the prosaic wear-and-tear of the American "hurry-up" life, without any poetry, any rest, or calm, when we cast from us the beautiful holiday-observances. (SL 9)

Written by an eighteen-year-old immigrant who has been in the country for less than five years, this letter demonstrates Antin's remarkable mastery of her new language and allows a rare 
expression of the author's disappointment. If there is a note of doubt in the ideas (and maybe ideals) that led her family to America, it is suppressed in her books. Neither From Plotzk to Boston, Antin's first book that came out at the time when this letter was written, nor The Promised Land, published a dozen years later, reflect the author's complex attitude towards America.

Antin's American Dream was inspired by her father's belief in the possibility of a better life and in America's opportunity and prosperity. After her father emigrated, Antin's vision of America was formed under the influence of his letters and the rumor-mill of her hometown. Jews in the Pale were short on "book-knowledge" and had to rely on letters from American relatives and stories told by people who came back from the United States. After many families had left and with many more planning to go, Antin describes the mood in the shtetl as "the emigration fever":

'America' was in everybody's mouth. Business men talked of it over their accounts; the market women made up their quarrels that they might discuss it from stall to stall; people who had relatives in the famous land went around reading letters for the enlightenment of the less fortunate folks; the one letter-carrier informed the public how many letters arrived from America, and who were the recipients; children played at emigrating; old folks shook their sage heads over the evening fire, and prophesied no good for those who braved the terrors of the sea and foreign goal beyond it; - and talked of it, but scarcely anybody knew one true fact about this magic land. (FPB 11-12)

Neither letters nor story-tellers could be trusted. People coming back from America used their “extraordinary imagination" in describing life across the ocean. Their eager but ignorant audiences were impressed by the stories that "surpassed anything in the Arabian Nights" (FPB 
12). What is striking about this account is the paucity of specific facts that would show where and how Americans or immigrants actually lived. Some knowledgeable neighbors warn wouldbe emigrants about the scarcity of featherbeds in America where people "sleep on hard mattresses, even in winter" or about policemen in Castle Garden who "take all their money from the passengers, unless the travelers deny having any" (PL 164). However, these details give only a sketchy picture of life in America.

Antin admits that she had known little about America before her father emigrated. It is hard for a small-town girl to envision anything grander than Vitebsk, the nearest big town, which gradually becomes surpassed by America in the author's imagination (PL 162). It was her father's dream and his hopes for success that inspired Antin:

I know the day when 'America' as a world entirely unlike Polotzk lodged in my brain, to become the center of all my dreams and speculations. [...in the father's letter] there was elation, a hint of triumph, such as had never been in my father's letters before. I cannot tell how I knew it. I felt a stirring, a straining in my father's letter. [...] My father was inspired by a vision. He saw something — he promised us something. It was this 'America.' And 'America' became my dream. (PL 142)

Commenting on this passage, Boelhower suggests that Antin puts 'America' in quotation marks "because it is merely an abstract ideal in the protagonist's mind" rather than a geographic place. Boelhower argues that the very abstractness of Antin's vision "charged [it] with biblical force" and that its "dream rhetoric" resonated strongly with American readers (33). It brought forth the ideal side of the American Dream — freedom and equality rather than accumulation of wealth.

Antin has her reasons for stressing these lofty ideals and declaring them a goal unto itself. The "something" of her father's promise better remains unspecified because after three years in 
America, he still had not reached financial security. Still, he was urging his family not to wait any longer to join him. He does not want his young children to waste "the precious years" that should be spent in American school "in learning English, in becoming Americans" (PL 162). Accessible education and freedom from discrimination were the main attractions for Russian Jews coming to the United States. As Antin learns from her father's letter:

In America [...] it was no disgrace to work at a trade. Workmen and capitalists were equal. The employer addressed the employee as you, not, familiarly, as thou. The cobbler and the teacher had the same title, "Mister." And all the children, boys and girls, Jews and Gentiles, went to school! Education will be ours for the asking, and economic independence also, as soon as we were prepared (PL 148).

Antin's words ring with utopian belief - in equality, in inevitable and guaranteed success. This conviction fuels Antin's enthusiasm and mitigates, if not eliminates the pain of parting from her native town. In the months before their departure from Polotzk, Antin lives "in a quiver of expectation" (PL162) although her ecstasy is based on rather vague notions of America: she does not know what America looks like and what kind of life people lead there, but it is enough for her to know that it is a place of great promise. Rather than being afraid of leaving the familiar town and her family home, she is looking forward to the change: "So at last I was going to America! [...] The boundaries burst. The arch of heaven soared. A million suns shone out of every star. The winds rushed in from outer space, roaring in my ears, 'America! America!'” (PL 162). This abstract, nebulous ideal allows Antin to establish ties to the place that she has not yet seen and that cannot be considered ideal by any stretch of imagination.

\section{ENCOUNTERING AMERICA}

The Boston to which the Antin family arrived in May 1894 was one of the centers of Jewish immigrant life in the United States. It is also an example of the transformations that were 
happening in American cities due to influx of new residents with their exotic languages and customs. James J. Connolly points out that, starting with the 1840, "Boston evolved from a Yankee town to a polyglot industrial city." The wave of "the famine Irish" was followed by a large number of British Americans arriving via Canada and by an even more numerous wave of Southern and Eastern Europeans (17), including Russian and Polish Jews. According to The Jews of Boston, from 1880 to 1900 , the city's estimated population grew from 363,000 to 561,000 , or by $54 \%$; during the same decades, its Jewish population increased almost ten-fold, from 4,0005,000 to 40,000 (343). William A. Braverman notes that late-nineteenth-century newcomers settled mostly in the North, West and South Ends of Boston, in the areas that had been the "most important centers of first-generation immigrants" since the Irish established their residence there in the 1850s. These neighborhoods were home to numerous ethnic groups, such as "Italians, Portuguese, Poles, Germans" (66) and, in Antin's words, "poor Jews, poor Negroes, and a sprinkling of poor Irish" (PL 195).

In many ways, Boston slums were similar to notorious tenement neighborhoods of New York City, where, as Howard B. Grose was writing in 1906, the conditions were "well nigh unbelievable" and where one could encounter

[t]he cellar population, the blind alley population, the swarming masses in buildings that are little better than rat-traps, the herding of whole families in single rooms, in which the miserable beings sleep, eat, cook, and make clothing for contractors, or cigars that would never go into men's mouths if the men saw where they were made. (201)

In Boston, as in New York, living conditions in slum districts were pitiful. In a 1902 article for the American Economic Association, Frederick A. Bushee quotes data from a survey of Boston tenement houses: practically all Jewish immigrants were living not in their own houses but in 
rented tenements ("Ethnic" 27) characterized by a "lack of privacy for family life" and poor amenities, often with "a single sink placed in the hall $[\ldots]$ for all the families on the floor" ("Ethnic" 26). In the North and West Ends, nearly one-fourth of the Jewish families (including some well-to-do) were "living with an average of more than two persons to a room" ("Ethnic" 30). ${ }^{2}$ Bushee also notes that a large proportion of immigrants occupied "unsanitary dwellings" ("Ethnic" 32); the average percentage of the Jews "living in tenements 'poor and bad' at least in one respect" was close to forty, but in some precincts it was as high as eighty ("Ethnic" 33). ${ }^{3}$ In spite of the poverty of immigrant Jews, they were not among the paupers - the poor who resided in almshouses — and relatively few Jewish families (0.36\%) received assistance from charities ("Ethnic" 85, 87). Since the Antins were starting at the bottom of the economic ladder, their living conditions were probably close to Bushee's descriptions of typical immigrant quarters, but Antin does not harp on negative impressions or unfavorable comparisons. On the contrary, she declares her immediate love for and connection to the city.

Looking at Boston through the prism of her ideal, Antin professes an admiration for her new place. As unlikely as such attraction to a slum neighborhood might seem, it becomes possible because of the abstractness of Antin's initial dream vision - a phenomenon described by Buell as "arriving at a place that seems a perfect spiritual fit, even if one has never before set eyes on it" (74). Antin's ecstatic expectations compel her to disregard the poverty and the ugliness that surround her family, to view their more than humble dwelling as temporary, as a stepping stone towards a better dream future. Antin describes her initial reaction as positive and registers no disappointment in her new place that appears to her "bewilderingly strange, unimaginably complex, delightfully unexplored" (PL 181). Her first encounter with America seems to be determined by the difference between the insider's and the outsider's views. 
According to Tuan, a fresh arrival's perception of new place is that of a visitor whose "evaluation of environment is essentially aesthetic [... and who] judges by appearance, by some formal canon of beauty" (64). Tuan considers the visitor's judgment valid because it offers a fresh perspective (65) but at the same time superficial because new settlers "perceive their new environment through the tinted glass of past experience." For a while after their arrival and before they "adapted somewhat to the new setting," newcomers still have "the urge to make comparisons and comment on their new home" (68). As a child, Antin might not have had "formal canons of beauty," but she is dazzled by her urban, technologically advanced surroundings that are so different from her rural home in Russia.

Antin presents the slum neighborhood in which her family lives as exotic, and her curiosity about the new place compels her to ask, "What have we here?-not, What does this mean?" (PL 181). Although Antin claims to have pondered the latter query later, she never attempts to answer it in the book; short on analysis, her account of the first weeks in America reads like an inventory. Antin states that on arrival, the rows of brick buildings seemed "imposing, loftier than any dwelling I had ever lived in. Brick was even on the ground for me to tread on, instead of common earth or boards" (PL 183). Antin is impressed by the illumination of the streets where "[1]ight was free; the streets were as bright as a synagogue on a holy day. Music was free; we had been serenaded, to our gaping delight, by a brass band of many pieces, soon after our installation on Union Place” (PL 186). From these observations, Antin jumps to a conclusion that "[i]n America, then, everything was free, as we had heard in Russia" (PL 186). Antin's description of many open "friendly" windows that are "filled with uncovered heads of women and children" (PL 183) confirm that, in spite of the impressive buildings, it is a typical working-class neighborhood. Tuan asserts that in such urban areas "the boundary between [the] 
dwelling and its immediate environs is permeable. All channels between dwelling and environment, such as open windows, closed windows, hallways, even walls and floors, serve as a bridge between inside and outside" — unlike middle-class areas where these boundaries are sharply defined (214). Antin considers the interest in the arrival of her family "very neighborly" (PL 184), probably because it reminds of her small-town childhood where neighbors know a lot about one another. On the whole, however, Antin's new place has little in common with Polotzk, but the novelty of her surroundings is exciting rather than intimidating to Antin.

Like most immigrants, the Antins have left behind most of their possessions and whatever standing they had in the Polotzk Jewish community. In Russia the family had known years of affluence and were "accustomed to upholstered parlors, embroidered linen, silver spoons and candlesticks, goblets of gold, kitchen shelves shining with copper and brass." By contrast with this former splendor, their American dwelling seems simple and unadorned:

The three small rooms into which my father now ushered us, up one flight of stairs, contained only the necessary beds with lean mattresses; a few wooden chairs; a table or two; a mysterious iron structure, which later turned out to be a stove; a couple of unornamental kerosene lamps; and a scanty array of cooking-utensils and crockery. (PL 184)

America, indeed, did not provide feather beds, but Antin is unperturbed by the loss of material things. She reverses the conclusion that seems to follow logically from these observations and contrasts "the cage of [her] provincialism" to "the brilliant universe" that surrounds her (PL 181). Antin is impressed with her new home because it is in America and because its meager furnishings are American (PL 184). If the sight is shocking or disappointing, the author does not mention it but maintains an optimistic tone that conveys a belief in the fulfillment of her 
expectations. Antin delights in every trifle of city life, looking for (and finding) "concrete embodiments of the splendors of America," such as "fine houses, gay shops, electric engines and apparatus, public buildings, illuminations, and parades [...] the letter carrier and the fire engine" (PL 197-198). In spite of her family's poverty, Antin is sure that these "common agents and instruments of municipal life" (PL 197) exist for her benefit too. Antin's American Dream supports her sense of entitlement and of belonging to this glamorous world.

Young Antin's enthusiasm is not surprising. As a child, not responsible for the family well-being and confident in her parents, she is somewhat protected from the dirt and the misery of her surroundings by a naïve belief that "[p]overty was a superficial, temporary matter; it vanished at the touch of money. Money in America was plentiful; it was only a matter of getting some of it, and I was on my way to the mint" (PL 298). It is, however, surprising that Antin the author offers little or no retrospective critical assessment of this unwarranted confidence. The only correction Antin allows is to state that her mother might have been the only person in the family who knew that "there was as yet no laying down the burden of poverty" (184). Indeed, getting to the mint proved to be difficult, if not impossible for Antin's parents.

The enthusiastic tone of Antin's narrative is disrupted when the author is describing her father's futile attempts to support his family. At close examination, it becomes clear that the narrative trajectory of Antin's autobiography does not correspond to what Boelhower calls "[t]he success myth (the myth of rags to riches) [that] is a major ideal of the American credo and is unique to its cultural code." According to Boelhower, American formula of success is simple: "one really need only have such virtues as personal initiative, sobriety, perseverance, honesty, industry, and frugality in order to win the material prosperity which 'Success' historically meant in America" (121-122). In reality, the qualities described by Boelhower failed to ensure to the 
Antin family even a decent living, to say nothing of wealth and prosperity. An inept businessman in Russia, Pinchus Antin remained an inept businessman in "the land of endless opportunity." As his daughter remarks, when he reached America, "he had surveyed many avenues of approach toward the coveted citadel of fortune," but all of them turned out to be "false starts" (PL 182). Neither his grocery store nor his refreshment stand bring enough income to the family; even with Antin's elder sister, Frieda, employed in a garment shop, the Antins cannot make ends meet and have to move often. ${ }^{5}$ Their life in America is a series of hardships rather than a dream come true - the fact underscored by Mary Antin's inability to establish emotional connections to her new places.

Antin's triumphant story falls apart when she is describing places and expressing her feelings towards them. Rather than demonstrating affection and a strong bond to her new home, Antin's contradictory statements reveal ambivalence to places. Antin often talks about her neighborhoods in edenic terms, such as "this pleasant nursery of America" (PL 180). She sees herself "behaving like a child let loose in a garden to play and dig and chase butterflies" (PL 197) — an odd metaphor for life in the slums of Boston. Although the family's apartment "gave [them] little besides meals in the kitchen and beds in the dark" (PL 273), she declares that "[i]t was impossible not to feel at home" there (PL 264). Thus, Dover Street for her is both a "fairest garden of girlhood, a gate of paradise, a window facing on a broad avenue of life [...and] a prison, a school of discipline, a battlefield of sordid strife" (286-7). Of course, Antin cannot help but notice the social stratification of the city; however, she refuses to accept her status in this hierarchy. Such denial of one's place is not unusual for people from the lower levels of society. Commenting on the feelings that city residents have towards their place in "the urban mosaic," Tuan distinguishes among "the very rich [who] are well aware of the bound of their world," the 
middle-class, "even more sensitive of their territorial integrity," and "slum dwellers [...who] may show little appreciation of the fact that they occupy districts of any special character with definable boundaries" (210-211). Antin realizes that she is a slum dweller. As Rokosz-Piejko observes, Antin perceives the places where her family has to live "as 'wrong,' because she knows that America is supposed to be the place of affluence, the place where people succeed" (176). However, she seems to be suppressing the negative emotions towards these "wrong" neighborhoods, but it is clear that Antin's optimistic hope for a soon-to-come prosperity does not protect her from bouts of depression.

Despite her effort to present a coherent narrative of typical assimilation and of individual achievement, Antin cannot completely hide her dissatisfaction with life. The text sometimes reveals facts that do not fit the success pattern and feelings that contrast with the overall enthusiastic tone. Thus, a few years after coming to Boston, Antin "began to believe [...] that America, after all, was not going to provide for [her] father's family" (PL 291). Antin also admits having "moments of depression, when [her] whole being protested against the life of the slum [...when she] resented the familiarity of [her] vulgar neighbors [...and] felt [...] defiled by the indecencies [she] was compelled to witness" (PL 298). Such confessions are rare in The Promised Land, but they do demonstrate the heavy effect of places Antin inhabited on her state of mind. Antin's letters written during her first years in America are even more revealing. Thus, on October 7, 1900, she complains to writer Israel Zangwill:

Everything is dull and disagreeable, nothing is right. I cannot do right myself, because I am as much dissatisfied when I do so as when I do wrong. It seems to me nobody does what is right. I think nobody cares and as all is unright it is also unbeautiful. There is nothing interesting to do or see. Half the time I hate my books even, and would not do my 
lessons but that I hate explanations and investigations. Take away my studies, what have I left? I do not write, because every word I write one day sounds false the next. Perhaps all this that I am telling you is false. (SL 30-31)

Antin also insists that she has "a sound right to be discontented [...] unhappy even if [she owns herself] all the truth" (SL 31). Is it the truth about the life of hopeless poverty she is leading or about the artificial, "false" optimism of her early writing? To reconcile her conflicting feelings towards her new home with the radiant image of American success, Antin transcends the boundaries of her surroundings and emphasizes her connection to the more glamorous parts of Boston.

As Antin tracks the peregrination of her family from one slum dwelling to another, it seems impossible for her to profess any strong emotional ties to them. At the same time, she refuses to be defined by her new home. This view contrasts the social determinism that was common in her time and harks back to a more romantic perception of environment. Whereas her contemporary immigrant autobiographer Jacob A. Riis says that "we are creatures of environment, that a man everywhere is largely what his neighbors and his children think him to be" (37), Antin insists that "Dover Street was never really [her] residence. It happened to be the nook where [her] bed was made, but [she] inhabited the City of Boston" (PL 340). When Antin rejects her slum neighborhoods and claims the ownership of Boston's public places, she compensates for the lack of material success and attempts to prove her belonging to her new country and culture. Antin associates herself with the library and the school- places that symbolize prosperity, culture, and education but are neither personal nor fit for living. One of Antin's favorite places in the city is the Boston Public Library, a "paradise" of learning, of “order and quiet $[\ldots]$ so unlike anything on Arlington Street" (PL 256). Having encountered a 
free-to-all library for the first time in her life, Antin calls it "my palace" and expounds her right of ownership:

Mine, because I was a citizen; mine, though I was born an alien; mine, though I lived on Dover Street. My palace — mine! [...] Here's where I liked to remind myself of Polotzk, the better to bring out the wonder of my life. That I who was born in the prison of the Pale should roam at will in the land of freedom was a marvel that it did me good to realize. [...] That an outcast should become a privileged citizen, that a beggar should dwell in a palace — this was a romance more thrilling than poet ever sung. Surely I was rocked in an enchanted cradle. (PL 341-2)

This passionate description of the library contrasts with a strong alienation from the tenement district in which the author lives. Antin's sense of ownership embraces not only the library but also the whole city which she surveys from the house roof like an "empress," exclaiming, "I love my beautiful city spreading all about me. I love the world. I love my place in the world" (PL 300). This vision is full of youthful optimism that is as abstract and nebulous as Antin's preemigration idea of America was. She is in the Promised Land, but the ideal is still in the future.

Although Antin avoids voicing her pain and disappointment, photos of Polotzk and of Boston included in the book tell a more complex story than the text. Some of the illustrations support Antin's argument almost point by point: the closed shtetl world opens up for her to include her class in public school, the reading hall of the Boston Public Library, the study of her benefactor Dr. Hale, a field excursion of the Natural History Club, and the distant ocean horizon. However, as Rokosz-Piejko asserts, the visual text challenges Antin's verbal narrative of transformation into an American citizen. Rokosz-Piejko contrasts the two sets of photographs, observing that "[f]ive out of eight pictures from Russia present a community in their collective 
effort [...including] scenes from the wood market and bread market, the washing of clothes in the river Dvina in winter, the place where boys used to study." By contrast, almost all photos of Boston, “are of places only [...with] hardly any people.” Rather than showing Antin's new community or her family, these pictures "present [...] the emptiness of the American spaces in the promised land" (175). What is lost for the immigrant is, according to Sheffer, "the intergenerational cohesion of communal life in Polotzk," and although Antin achieves "unfettered access to public space in Boston," it is done at the cost of "the near-total exclusion of human bodies" (155). Moreover, the expanded place means, in effect, placelessness. While in the traditional way of Polotzk life everybody had a place (both literally and figuratively), the free but alienated spaces of American cities do not provide any stability of residence or employment. "Owning" the public library and the whole city of Boston might sound glamorous, but Antin cannot call her own the succession of dingy apartments that her family occupies in grimy neighborhoods.

\section{DEFENDING THE AMERICAN IDEAL}

Avoiding possible complexity of personal feelings, Antin seems to be addressing her readers on behalf of all immigrants. She attempts to redeem immigrant slums in the eyes of Americans, presenting big-city tenement district not as a breeding ground for crime or a stronghold of alien customs but as a springboard for ambitious individualism - the very essence of American identity. Antin admits that in the slums of Boston, immigrants live, "for the most part, as unkempt, half-washed, toiling unaspiring foreigners." At the same time, she declares the poor districts to be "the touchstone of American democracy" where newcomers learn American ways. The poverty and poor living conditions are a difficult but necessary part of an immigrant's life: "the slum [is] a sort of house of detention for poor aliens, where they live on probation till they can show a certificate of good citizenship" (PL 183). One of the ways to acquire such 
certificate is through education. Antin describes her parents and neighbors as people who "value[...] education, and set[...] a great price on the higher development of the child." Many poor immigrant families make sacrifices to keep their working-age children in school; they "borrow, beg, go without, run in debt—anything to secure for a promising child the fulfillment of the promise. That is what America was for." Immigrants might be strange people who, to the horror of the board of health, "pitch rubbish through their windows," but their goals in life are the same as those of hard-working Americans (PL 353-354). Their means of achieving these goals are also honorable: "We are all honest workmen, and deserve standing-room in the workshop of sweating humanity," declares Antin (PL 269-270). She claims commonality of values with the rest of the country and asserts the rights of immigrants to be accepted as Americans.

Although Antin's impressive personal accomplishments—she graduates with honors from a grammar school and is admitted to an exclusive Latin school—give her some grounds for trusting the promise of the American Dream, her family seems to be forever mired in the struggle for survival. Antin cannot present facts that would complete the expected success pattern of her narrative; neither can she boast of an address that would signal upward mobility. To overcome this rhetorical challenge and to maintain the optimistic tone of the book, the author gives less and less space to accounts of events or descriptions of places. The concluding chapters of the book are short on personal details but full of lofty pronouncements such as this:

From my little room on Dover Street I reached out for the world, and the world came to me. Through books, through the conversation with noble men and women, through communion with the stars in the depth of night, I entered into every noble chamber of the palace of life. I employed no charm to win admittance. The doors opened to me because I 
had a right to be within. [...] Being set down in the garden of America, where opportunity waits on ambition, I was bound to make my days a triumphal march toward my goal. [...] A glowing life has been mine, and the fires that blazed highest in all my days were kindled on Dover Street. (PL 355)

Apart from being vague and abstract, this passage also reveals the paradox of Antin's stance: is any ambitious newcomer bound to march triumphantly towards his or her goal, or is it the author's exclusive right? Antin's book, in the spirit of Emerson's philosophy, provides an inclusive rather than exclusive answer.

On the one hand, Antin positions herself as a representative of a whole class of immigrants. She compares her Americanization process with that of "the most ignorant" immigrants who begin their American experience immediately on arrival when they and their old-country manners are "corrected, admonished, and laughed at, whether by interested friends or the most indifferent strangers" (180). Due to this friendly greeting from benevolent Americans, newcomers start on their smooth path to assimilation, which for children in particular is ensured by free education. School is a place where Antin and other young immigrants "imbibe American ideas" (PL 277) and learn to declaim "patriotic verses in honor of George Washington and Abraham Lincoln, with a foreign accent, indeed, but with plenty of enthusiasm" (PL 206). Antin takes advantage not only of the school instruction but also of "her country's promise to a woman" (PL 277). Whereas a girl growing up in the Jewish Pale of Russia is expected to enter an arranged marriage at an early age and to spend the rest of her life within the narrow circle of her family, Antin and other female immigrants are entitled to "[a] long girlhood, a free choice in marriage, and a brimful womanhood [that] are the precious rights of an American woman" (PL 277). Although she barely mentions the fact in the book, at the time of writing her autobiography 
Antin is already married and has a daughter. ${ }^{7}$ What is important is that her family status cannot prevent her from becoming a published writer and that she is enjoying the rights granted to certain American or immigrant women.

On the other hand, Antin sees the circumstances of her life and her destiny as extraordinary. She is conscious "of the unique elements in [her] character and history," believing that she is "pursuing a single adventure since the beginning of the world" (PL 296). Her path to Americanization is, indeed, exceptional. Not only is she privileged among her siblings and given a chance to study rather than work, she is also supported by teachers, wealthy Jewish patrons, and other admirers of her precocious intellect. Antin admits being "watched and coaxed [as well as...] passed along from hand to helping hand" (PL 214). Not surprisingly, one of the factors that allow her to claim the city of Boston as her own is the presence of numerous friends who "sprang up everywhere, as if they had stood waiting for me to come" (PL 214) and who would welcome her in their houses (PL 340). Antin's perception of places is colored by her tremendous confidence both in the viability of the American Dream and in her own abilities to answer "to the call of [her] genius" (PL 297). This self-confidence is the magic light that illuminates for her the wretched slums in which she lives:

I did not seek my kingdom. I had only to be worthy, and it came to me, even on Dover Street. Everything that was ever to happen to me in the future has its germ or impulse in the conditions of my life on Dover Street. My friendships, my advantages and disadvantages, my gifts, my habits, my ambitions - these were the materials out of which I built my after life, in the open workshop of America. My days in the slums were pregnant with possibilities; it only needed the ripeness of events to make them fruit forth in realities. Steadily as I worked to win America, America advanced to lie at my feet. I 
was an heir, on Dover Street, awaiting maturity. I was a princess waiting to be led to the throne. (PL 358)

Antin's exalted tone and her royalty metaphor stand in sharp contrast to the realities of immigrant life as well as to the author's claim of representativeness. Handlin draws our attention to "the tinge of egotism in the book which set the goal of self-expression as the supreme good. Polotzk was inadequate because it frustrated the individual's quest for fulfillment. America was satisfying because it opened the way toward that goal." Handlin further argues that Antin's selfexpression impulse is based in "Emersonian individualism, the spirit of which descended to Mary Antin by way of the Lazarus sisters" (xii). ${ }^{8}$ Similarly, it is Emerson's understanding of an individual's place in history that allows Antin to ascribe universal worth to her exceptional story. If, as Emerson declares, "there is properly no history, only biography" (127), by writing her autobiography, Antin is writing the history of America as a country of immigrants. Antin's acquired individualism adds fuel to the fire of her initial American Dream, compelling her, in spite of all evidence to the contrary, to maintain the enthusiastic tone of the autobiography. Emersonian aspirations to human values that transcend religious and ethnic boundaries might have also influenced Antin's views on the position of Jews in the United States.

Antin's vehement defense of the American ideal in The Promised Land results in a silence about anti-Semitic attitudes among native citizens of her new country. However, historical evidence suggests that Boston of the late 1800s was not free of ethnic tensions. Even before the influx of South and East Europeans, the city was already, as Connolly puts it, "plagued" by anti-Irish and anti-Catholic sentiments that were increasing in the 1880 s because of “the growing Irish political power" (18). The arrival of East European Jews upset the life of Boston's small Jewish community_mostly German Jews who had “experienced a fair degree of 
social and political success" and intended "to blend fully into American life." The exotic new comers from Russia and Poland posed a challenge to this goal, attracting attention by their "distinctive customs." Their "visible presence" forced well-established Boston Jews to create "a clear Jewish political identity" within the ideological framework of Progressivism and, after initial suspicion towards East European Jews, to help them through newly established charitable institutions (61-62). Describing the interaction between the German Jews and East European newcomers, Lazarus states that the former are constantly being recruited [...] from below [by] the tide of immigration [that] pours into us its troubled waters, - the ignorant, the superstitious, the outcast, the outlandish of the nations, the slaves of centuries of bondage. To feed, to clothe, to shelter them, to give them bodily comforts, is a task taxing our utmost strength. To feed them spiritually is the task almost beyond our strength. (Spirit 128)

Contrary to Lazarus's romanticized view of this civilizing mission, the motives for this assistance were not always altruistic. As Chaim I. Waxman suggests, "the German Jews perceived the Eastern Europeans immigrants as uncouth, destitute, uncivilized, and therefore threatening to their own position in American society," especially since the new arrivals often became involved in labor movement (9). Elevating new immigrants out of poverty was a means of Americanizing and de-radicalizing them. Waxman notes that East European Jews, in turn, perceived the German Jews as snobbish, "strongly resented[ing]" the latters' attempts to accelerate their assimilation (9). In addition to tensions existing between different waves of Jewish immigration, other native ethnic groups were even less welcoming.

Antin arrived in America during the heyday of eugenics, a social movement that marked South and East European immigrants, including Jews, as undesirable and inferior races. Based on 
the theories of Sir Francis Galton developed in the late 1800s, the movement became popular in the United States in the early 1900s — partially as a reaction to what Madison Grant, one of the ideologues of eugenics, saw as "an alien invasion" of America by new immigrant (Conquest 223). In his 1918 treatise, The Passing of the Great Race, or the Racial Basis of European History, Grant contends that the new immigration "contained a large and increasing number of the weak, the broken, and the mentally crippled of all races $[\ldots]$ together with hordes of the wretched, submerged populations of Polish Ghettos.” As a result, American “jails, insane asylums and almshouses are filled with this human flotsam and the whole tone of American life, social, moral and political has been lowered and vulgarized by them" (89-90). Grant accuses new immigrants of "crowding out" the so-called old stock out of their districts and out of jobs; in particular, he unleashes his anger at "the swarms of Polish Jews," claiming that "they adopt the language of the native American, they wear his clothes, they steal his name and they are beginning to take his women, but they seldom adopt his religion or understand his ideals" (91). Grant was not alone in his fear of the alien who would never be able or willing to assimilate. Brodkin quotes an 1893 article from the New York Times that describes a Lower East Side Jewish neighborhood as "the filthiest place on the western continent," populated by immigrants who "cannot be lifted up to a higher plane because they don't want to be" (29). Such sentiments were common not only in New York City that contained by far the largest immigrant population in the country but also in Boston. ${ }^{9}$ Significantly, in July 1894, only two months after Antin's arrival, a group of prominent Anglo-American Bostonians organized Immigration Restriction League whose goal was to "advocate and work for the further judicious restriction or stricter regulation of immigration [...] and to arouse public opinion to the necessity of a further exclusion of elements undesirable for citizenship or injurious to our national character" 
("Constitution" 1). This initiative of Boston Brahmins received support from other parts of the country and was instrumental in passing The Literacy Test Act of 1917 and the Immigration Act of 1924. The League's racist premises are apparent from the fact that Madison Grant served as its president from 1922 till his death in 1937.

Coming from the country of virulent, violent, and institutionally entrenched antiSemitism, Antin and other Russian Jews must have experienced a considerable improvement in their personal freedom and in the society's attitude towards them as a group. Nevertheless, antiSemitic discourse during the nineteenth and the early decades of the twentieth century, although comparatively moderate, was wide spread. Frederic Cople Jaher claims that anti-Semitic sentiments were expressed in print by many Southerners as well as by prominent abolitionists, such as Theodore Parker, Lydia Maria Child, William Lloyd Garrison, and Edmond Quincy (200-202). Jaher also identifies the 1840 s as the start of "systematic commercial discrimination against Jews" (203) and the spread of the stereotypes of Jews "as secretive, deceptive, and skillful economic predators" (205). Several publications of the late 1800s-from the New York Herald to Harper's Weekly to the scholarly North American Review — had a habit of disparaging Jews and alerting Americans to the danger they allegedly presented (220). The pattern continued well into the twentieth century, with Henry Ford's Dearborn Independent (1901-1927) and eugenics pamphlets. It is true that proponents of eugenics marked all newcomers from Eastern and Southern Europe as belonging to inferior races (Alpine and Mediterranean respectively), but they also targeted Jews as particularly harmful for America. Even the motives that pushed Russian Jews towards emigration were misrepresented. For example, referring to the Czar's discriminatory laws in a seemingly dispassionate sociological study of Boston immigrant districts, Bushee refutes "Jewish sympathizers" who would consider these laws "an uncalled-for 
persecution, an outrage against humanity [...resulting from] mere meaningless hatred.” Bushee claims the contrary, namely that the laws were just a reaction to "the old story of money-lending Jew" for whom the Russian peasant "was, of course, no match" and from whose "grasping and relentless power" the Czar had to protect his subjects ("Invading" 49-50). Such insinuations implied a warning to Americans and created ground for hostility and discrimination.

It is unlikely that at the time of writing The Promised Land Antin was unaware of the anti-Semitism of her new country, so she must have had her reasons for not addressing this problem in her autobiography. On the rhetorical level, if Antin's goal was to contrast America to Russia, relating instances of hostility or admitting the existence of discrimination against Jews would have collapsed the opposition she was trying to construct. Moreover, the absence of antiSemitism from Antin's narrative reflects her complex attitude to Jewish religion and tradition. During her first years in America, Antin had supporters among assimilated Sephardic and German Jews (Lazarus and the Hecht family). She was influenced by their assimilationist views, such as those expressed by Lazarus who was certain that the newcomers will not be "satisfied to practice their religion, to shut themselves off from other men" (Spirit 128). Lazarus suggests that Jews should "plunge in the ocean of humanity" without waiting for the world to be ready to accept them. With optimism possible at the turn of the century, Lazarus compares anti-Semitism with "a dark cloud upon the horizon [that...] still lingers in lands where darkness lingers." By contrast, in America, it "disappears again when we ignore it, when we have learned to live far and away above and beyond it, in the peace and freedom of large and liberated ideas" (Spirit 159-161). This is what Antin seems to be doing in The Promised Land-ignoring anti-Semitism as a transient phenomenon. In a 1917 article, she explicitly claims for Jews the right to assimilate (“Zionist's" 157) but never addresses the anti-Semitism directly. ${ }^{10}$ 
As the narrative of The Promised Land progresses, not only Antin's descriptions of places but also her accounts of family circumstances become vaguer and less specific. For example, she does not elaborate on how the Antins have moved out of the "underworld" of the slum and into "a darling cottage of [their] own, where the sun shines in at every window, and the green grass runs up to [their] very doorstep" (PL 357). As always, Antin wants to show her family's advancement as typical for immigrants in general, presenting the move into a more pleasant residential area as inevitable and practically guaranteed by the Pilgrim Fathers "who transcribed their field notes on a very fine parchment and called it the Constitution of the United States" (PL 357). However, it was none of the American virtues described by Boelhowerpersonal initiative, sobriety, perseverance, honesty, industry, and frugality - that paved the family's way out of the ghetto. By Antin's admission, they “found a short-cut” (PL 357), which, as Mazur's research reveals, was the help of Antin's husband, Amadeus Grabau, a secondgeneration German American who had just earned his doctoral degree in geology from Harvard and accepted a position at Columbia University. It was he who bought the Dorchester house for his wife's parents (119), but this detail would not have fit the pattern of Antin's Americanization story. Sheffer rightly considers Antin's version of events to be "itself a short-cut, a narrative cheat" that substitutes fiction for autobiographical experience in order to create the desired narrative coherence (159). One might add that this substitution is dictated by Antin's rhetorical goal of proving immigrants' potential to assimilate and succeed. Moreover, it shows that Antin is expanding her American ideal to incorporate the virtues of rural life.

Describing her parents' move from Boston slums to the country, Antin asserts that this kind of life is "better for the growing children, better for [her] weary parents, better for all of [them], as the clean grass is better than the dusty pavement" (PL 357), thus changing her vision 
of an ideal place from a glamorous city to a small town, not unlike Polotzk. Antin does not stop at that. Quite unexpectedly, she declares that her "favorite abode is a tent in the wilderness, where [she] shall be happy to serve [the reader] a cup of tea out of a tin kettle" (PL 360-361). Handlin attributes Antin's change of attitude "not only [to] the personal enthusiasm connected with her marriage [to a science professor Amadeus Grabau] but also [to] the pantheistic attitudes connected to Josephine [Lazarus]" (xi). Under Lazarus's influence, Antin develops transcendentalist beliefs and views her assimilation as a "triumphant re-invention as an Emersonian American" (Kellman 153). Although she is a newcomer, Antin might have grasped the inherent dichotomy of the American identity and, having staked the city as her (and immigrants') domain, is now claiming the countryside and the wilderness. Another reason for including into her autobiography this "paean to nature" (Handlin xi) could be nostalgia for the semi-rural, now remembered as idyllic, setting of her childhood. Led by her American Dream, Antin might have lost more than the chains of oppression.

\section{AFTER THE PROMISED LAND}

Antin finishes her autobiography on a high note, declaring, "Mine is the whole majestic past, and mine is the shining future" (PL 364), but at no point in her book can she relate to her present or identify a place where she feels at home. Antin's life after the publication of The Promised Land demonstrates that the promise of the American ideal and her hopes for the shining future were not to be fulfilled. Antin's two decades of stable and productive life (19001918) resulted not from the family's material success but from her marriage. As a "Frau Professorin" (SL 38), Antin follows her husband to New York where she lives first in "a dear little home near the [Columbia] University" (SL 37) and later in a spacious house in Scarsdale. ${ }^{11}$ By her own admission, Antin is "not a domestic woman" (SL 96), so she has servants to take care of the household chores and of her daughter, Josephine. It is somewhat surprising that in 
spite of her declared belief in the value of education, Antin only takes a few college courses and never graduates. Although in her 1902 letter she mentions a plan for "a great novel” (SL 38), after the autobiography she only publishes a couple of stories and a handful of argumentative essays. The success of The Promised Land makes Antin a well-known author and a popular public speaker, campaigning for Progressive Party candidates and championing open immigration policy. Antin's polemical writing sheds additional light on the way she sees her place in American society.

In 1914, Antin publishes a pamphlet They Who Knock at Our Gate: A Complete Gospel of Immigration, in which she argues against the proposed restrictions on immigration. Antin attempts to prove that immigrants are neither a burden on the country nor undesirable elements incapable of assimilation; the foundation for her argument is both practical and moral. As the very title of the essay demonstrates, Antin relies heavily on biblical analogies. Thus, she compares the Declaration of Independence to the Ten Commandments and asserts that both “must be taken literally and applied universally" (TWK 14). In Antin's opinion, the Declaration guarantees to "the newest arrival the same rights as [to] the established citizen" (TWK 13) and the question of immigration should be decided on the basis of "spiritual bonds" and "moral principles" rather than of economic considerations (TWK 12). As in The Promised Land, Antin uses the language of familial relations to establish continuity between new arrivals and nativeborn Americans. She compares America to the mother of an impoverished family who "divides her last crust equally among her starvelings" rather than "strangle half her brood" to feed the other half (TWK 103). In contrast to this image of deprivation, Antin stresses the unlimited economic possibilities of America's enormous territory. 
Although Antin goes against the prevailing opinion on immigration, she shares her contemporaries' views on the country's westward expansion and their racial prejudices. One of Antin's arguments in favor of open immigration policy is the availability of land - "the vast regions that are still waiting to be staked out" (TWK 20), to which newcomers have as much right as the earlier immigrants had. She glorifies the pioneers who have "wrenched their estates from the wilderness by the labor of their own hands"- wilderness "peopled with savages" (TWK 20-21, 131). When Antin admits that white Americans cannot "lay claim to the land on the ground of priority of occupation as long as a red man is left on the Indian reservation," she not only acknowledges the rights of earlier inhabitants but seems to be marking Indians as destined for extinction (TWK 21). At the time when the Progressive Movement is debating citizenship rights for Native Americans, Antin sees them only as "the Indian[s...] with bloody tomahawk and a stealthy arrow" (TWK 67). Antin has even less to say about black Americans. Although she boldly proclaims that the Civil War "wash[ed] away any lingering doubts as to the brotherhood of men of different races" (TWK 10) and asserts that the all men of the Declaration of Independence is meant to include "yellow men as well as white men" (TWK 18), this hint at African Americans and the vague mention of Asian immigrants seem to be just rhetorical moves. Antin's real defense is for aliens from her own part of the world_-Jews, Greeks, and Italianswho at the time would not be considered white by many opponents of open immigration.

To show that new arrivals are worthy of American idealism, Antin equates them to the Pilgrims. East European immigrants "cherish similar dreams" (TWK 75) and, similarly to the first New England settlers, "relished the bread of freedom" (TWK 74). Most Russian Jews of Antin's days are "fugitive[s] from religious prosecution" (TWK 38) and choose the ordeal of emigration and exile in America over the stable but oppressive life in the Pale. Curiously, when 
Antin wants to contrast the Old and the New Worlds, she brings up the same image of America's featherless beds that has already cropped up in The Promised Land. She declares, "Better a hard bed in the shelter of justice than a stuffed couch under the black canopy of despotism" (TWK 74), thus summing up the losses and gains of emigration in terms of domesticity and place. After arriving in America, new immigrants work towards the same purpose as the Pilgrims did in their time. Antin's contemporaries come to this land "not to despoil, but to build [...and] are awaiting God's miracle of human happiness." But the America of the early 1900s is different from the pastoral scene of the colonial time: immigrants toil "in the grisly darkness of the mine, in the fierce glare of the prairie ranch, in the shriveling heat of coke-ovens, beside roaring cotton-gins, beside blinding silk-looms, in stifling tailor-shops, in nerve-racking engine-rooms" (TWK 57). As in her descriptions of the slums in The Promised Land, Antin uses this harrowing inventory of immigrant places not to explore the traumatic experience but to praise the self-made men and women who have overcome these obstacles.

Considering her family history, success or failure of immigrants is a sensitive subject for Antin, and when she attempts to account for the disparities between those immigrants who do and those who do not advance, she seems to subscribe to the doctrine of social Darwinism that was wide-spread in the beginning of the twentieth century. On the one hand, she claims that, in general, immigrants are "not the refuse, but the sinew and bone of all the nations" (TWK 63), people who had both the courage to leave their home country and "the highest combination of the physical and moral virtues" (TWK 64). Antin even goes as far as suggesting that "with every shipload of immigrants we get a fresh infusion of pioneer blood" (TWK 64) that is necessary for keeping America from degeneration. ${ }^{12}$ She contrasts "the upward process" that is going on in the immigrant slums of New York to "the downward process" in the New England hills, in the midst 
of Yankee farmers who used to be "prime American stock" (TWK 62) but lost their vigor to western expansion. As in emigration from Europe, the westward movement swept away "the best blood, [...leaving behind] the less robust, the less venturesome" (TWK 63) and creating the need for the refreshing influx of immigrants. On the other hand, Antin admits that "there are weaklings in the train of the sturdy throng of foreigners" (TWK 67). Being so closely familiar with the life of the slum, Antin has "witnessed the pitiful struggles of the unfit, and [has] seen the failures drop all around [her]" (TWK 68). Would she place her own father in the category of "the unfit"? He could hardly be ranked among those self-made immigrant men whom Antin applauds as "the noblest product of our democratic institutions" (TWK 76). Antin's reliance on the struggle for survival theory begs another question: is her story representative of the immigrant experience or is it exceptional? This tension remains unresolved in Antin's writing.

Among the unexplained paradoxes of Antin's life is her opposition to women's suffrage, which seems uncharacteristic of this outspoken and independently minded woman who openly stood up against the pervasive xenophobia of her contemporaries and advocated Zionism. Therefore, it is not surprising that some scholars mistakenly declare, as does Handlin in the foreword to the 1969 edition of The Promised Land, that Antin "helped convert Theodore Roosevelt to the cause of women's suffrage" (xiii). These misconceptions might be based on the 1913 serialized version of Roosevelt's autobiography where he, according to Mazur, states that "women like Jane Addams, Mary Antin, and Frances Kellor" made him "a zealous [...] adherent of the cause." After Antin corrected Roosevelt's mistake in a letter, he changed the wording of the passage for the book edition of his autobiography, adding that "a few of the best women of the same type, women like Mary Antin, did not favor the movement" (qtd. in Mazur 154). We 
can only speculate about Antin's reasons for opposing women's rights because she never voiced them in her published writing.

It is possible that Antin's views on women's suffrage were influenced by those of Josephine Lazarus, her older friend and mentor, and ultimately by Emerson's ambivalent stance on women's rights. Similarly to Emerson, Lazarus attributes to women superior spiritual powers but also cautions her gender against venturing into the public sphere. In "Higher Education: A Word to Women," her 1890 open letter to the magazine The Century, Lazarus admits that some "exceptional" women are gifted enough "to excel where men have excelled, in scientific and professional pursuits," at the same time declaring that for reasons "deep seated in [female] constitution and in the constitution of society" it is not advisable for young women to be "subjected to the mental strain and strict training required to fit them for a profession." She proclaims marriage to be "a career for a woman, in most cases incompatible with any other career" (316). In her 1899 pamphlet Madame Dreyfus: An Appreciation, Lazarus goes even further in extolling "an ideal of true womanhood [that is] leading the human race ever onward and upward" (9). Indeed, Lazarus is placing woman into a position of leadership when "she goes forth into the unknown world, with a man by her side to work out the salvation together by the sweat of their brows. For where Woman leads, Man ever follows-provided she remain Woman" (11). However, Lazarus asserts, if woman develops “along purely intellectual lines, or indeed in any direction with the same success as men," she is bound to lose her womanhood and, consequently, her power and "that celestial, that divine passion that moves the world" (51). Lazarus hoists woman on a pedestal and charges her with the impossible task of elevating and civilizing the human race. Acknowledging the importance of education for women, she is not 
demanding for them access to public forums or professions. ${ }^{13}$ Antin seems to occupy a similar middle-ground position.

It would be wrong to say that for Antin the "brimful womanhood" (PL 277), which America promises to female immigrants, does not expand far beyond hearth and home. If success meant an advantageous match, Antin's autobiography would have given more attention to her own marriage; instead, it emphasizes the author's intellectual accomplishments. Still, Mazur might be right when he explains Antin's opposition to women's rights by the influence of her conservative husband (155). A successful writer and a public figure, Antin seems to have outwardly broken away from the Jewish tradition that subordinates women to men. Nevertheless, she refrains from going a step further and demanding political equality for her gender. Antin could have been just prioritizing the causes and focusing all her eloquence on immigration, but she also, as Saltz argues, "exhibited some form of male hero-worship throughout her life," and her well-being seemed to always depend on a dominating male figure - her father, her husband, or spiritual teachers whom she followed later in life (90). When by the end of World War I her marriage disintegrates, so do her health and creativity. The loss of family results in placelessness. $^{14}$

During the last thirty years of her life, Antin is separated from her husband and suffers from bouts of mental disease, which she calls "a deep soul sickness" (SL 137). According to Handlin, "except for brief flashes, the power of expression that shone in The Promised Land left her" (xiv). Having lost her ability to write, Antin immerses herself into a spiritual and religious search. As an adolescent, she seemed to take in stride her family's constant moves from one miserable apartment to another: 
There was a charming simplicity about these proceedings. Here to-day, apparently rooted; there tomorrow, and just as much at home. Another basement grocery, with a freshly painted sign over the door; the broom in the corner, the loaf on the table- these things made home for us. (PL 264)

Ironically, instability becomes Antin's lot again—sans any charm. Antin has no home of her own and lives at different times in Albany — as she puts in one of her letters, like "a bird of passage under [her sister's] most hospitable roof' (SL 142); at Gould Farm (a Christian facility for mental-health patients) in Massachusetts; at the Harmon-on-Hudson retreat of Meher Baba (an Indian mystic and spiritual teacher). In 1947, after a train accident that leaves her with "several fractured ribs and profound shock," the fifty-six-year-old Antin has to spend five months in a nursing home, from which she is hard-pressed to find "more normal and pleasant" quarters (SL 143). In her letters, Antin seems to be reconciled to her placeless existence, declaring, "A vagabond I shall remain, it is certain, to the end of my days on earth" (SL 145). She dies two years later, still a vagabond.

Antin was among the first and, for a while, the most successful of immigrant autobiographers. She published her book at the height of immigration wave from Eastern Europe, when many native-born Americans perceived the influx of numerous ethnic and religious groups as a threat. Antin adds her voice to the nation's immigration policy debate, presenting her story of following the American Dream as proof of immigrants' potential for assimilating and succeeding in America. Antin contrasts the life of restriction and oppression in Russia to the life of freedom and equality in America, bringing forth the idealistic side of the American Dream. The facts of Antin's life do not always support this binary opposition, but she 
glosses over the hardships and traumas of adjusting to the new country and maintains an enthusiastic tone. Antin might be sincere in conveying her initial radiant vision of America, but she is also suppressing all negative emotions she might have had during the first American years. She refuses to admit that there is a gap between her expectations and reality or to acknowledge any losses resulting from immigration. Significantly, in 1910-1911, while Antin was working on her autobiography, she traveled to Europe with her husband and daughter and visited her native town. If what she saw in Polotzk had confirmed the sharp contrast between her old and her new countries, Antin did not include it in the text as an additional proof of America's superiority. Other immigrant authors (including Eva Hoffman and Miriam Potocky-Tripodi discussed in Chapter 3) who came to America as children and then returned to their native places as adults report complex emotional reactions to these encounters. If Antin's homecoming resulted in similarly ambiguous feelings, they would not have fit with the rhetorical mode of her book, which might be her reason for excluding this event completely.

Antin's deliberately chosen "cheerleader" position determines her portrayal of places. Although Antin gives truthful descriptions of the poor immigrant neighborhoods, she is compelled to interpret her family's hopeless poverty in the light of her optimistic beliefs. Antin cannot report any profound attachment to her domestic places. On the contrary, she claims ownership of and bonds to public places of Boston that embody for her the idealistic promise of the American Dream. In a way, America does deliver on its promise: although Antin family businesses fail one after another, Mary Antin gets an education that would have been beyond her reach in Russia and that becomes her ticket out of poverty. In spite of her social success, Antin never finds her ideal place; in fact, as her status improves, the vividness and specificity of place descriptions in the book wane. The study of Antin's life after the publication of The Promised 
Land shows that she was not able either to establish connection to places or to maintain the triumphant zeal of her early books. In fact, she was not able to write at all and did not have a home of her own for the thirty years preceding her death. The dissonance between Antin's idealized picture of America and the harsh reality of her life went unnoticed for decades. As the author intended, the book was perceived as a typical immigrant story of successful assimilation and upward mobility, but the omissions and denials of Antin's autobiography now reveal the complexity of Antin's relations to place.

${ }^{1}$ Antin's home town is Polotzk, a shtetl within the Jewish Pale of Settlement in what was then the Russian Empire. The typesetter of her first book misspelled the name, probably confusing it with similarly sounding Plotzk, a town in Poland. Antin decided to let the error stand (Saltz 3). ${ }^{2}$ According to Bushee, only the Italians were more crowded than the Jews, but the former were mostly groups of single men renting rooms in groups of ten or even twelve whereas the latter were mostly families with children ("Ethnic" 29-30). Many Italians in those days came to America for economic reasons, leaving their families behind. By contrast, Russian Jews, who were escaping persecution and discrimination, "emigrated in families" more than other ethnic groups except the Portuguese ("Ethnic" 18). The Jews and the Southern Italians were also the poorest groups who brought with them to America an average of $\$ 9$ per person. Other European countries produced more wealthy immigrants who arrived with some initial capital: the English $\$ 40$, the Scotch $\$ 36$, the Germans $\$ 30$, the Northern Italians $\$ 23$, the Irish $\$ 15$ ("Ethnic" 14). ${ }^{3}$ The only group with more members (more than $56 \%$ average) living in unsanitary conditions were the Italians ("Ethnic" 33), which was, as Bushee explains, the result of the "objectionable" life style of single men ("Ethnic" 29). 
${ }^{4}$ Jacob A. Riis's (1849-1914) 1902 autobiography, The Making of an American, is an example of this pattern. Riis comes to America at the age of 21 and gradually overcomes all hardships to acquire a respectable position in society, achieve personal happiness, and become truly American. Descriptions of hardships play a similar role in Anzia Yezierska's (1880-1970) highly autobiographical stories in the 1920 collection Hungry Hearts. Although Yezierska focuses on the protagonist's spiritual search for the America of her dream rather than on material success, it is the slow and persistent buildup towards a triumphant declaration, "Through my inarticulate groping and reaching-out I had found the soul—the spirit—of America!” (180).

${ }^{5}$ Not only the Antins but many immigrant families had to send their teenage children to work rather than to school. Bushee notes that "the wage-earning capacity of the children is all important" for the poorest ethnic groups, such as the Jews and the Italians ("Ethnic" 21) ${ }^{6}$ Bushee corroborates Antin's claim. He reports that “among some of the Jewish families education seems to be more highly prized than it is by any other nationality." Poor Jews often make "considerable sacrifice" to send a promising son to school or even college ("Ethnic" 21). Antin's family is exceptional because it supports the intellectual development of Mary rather than of her younger brother.

${ }^{7}$ Antin's husband and daughter are mentioned only in the last-page Acknowledgements. ${ }^{8}$ Emma Lazarus (1849-1887) was a Jewish American poet and the author of "The New Colossus" (1883), part of which is engraved on the pedestal of the Statue of Liberty. Diane Lichtenstein notes that soon after Emma, aged seventeen, published her first book of poems, she met Emerson who became her mentor and a supporter of her poetic talent. The two poets corresponded until Emerson's death in 1882 (Lichtenstein). Although Antin never met Emma Lazarus, she befriended the poet's younger sister Josephine Lazarus (1846-1910). According to 
Sue Levi Elwell, the ancestors of the Lazarus sisters were Sephardim Jews who landed in New Amsterdam in 1654. Brought up in wealth and privilege, both sisters nevertheless took a keen interest in the conditions of Jewish immigrants arriving from Eastern Europe (Elwell). In 1899 Lazarus read Antin's first book, From Plotzk to Boston, and sought out the young author. As Antin states in a letter to Zangwill, Lazarus took interest in Antin's writing and advised her to keep a journal (SL 7). Soon after that, Lazarus wrote a review of Antin's book, praising its "peculiar charm, at once childlike and mature" (317). Mazur quotes Antin's letter where she says that she sees Miss Lazarus frequently (108); he also notes that Lazarus read the first few chapters of The Promised Land in manuscript but died before the book was completed (126).

${ }^{9}$ In 1907, Grose presented the following data of immigrant distribution for the fiscal year ending on June 30, 1905: New York 315,511—31\%; Pennsylvania 210,708—20.3\%; Illinois 72,770— 7\%; Massachusetts 72,150—7\%; New Jersey 57,258—5.3\%; Ohio 49,351—5\% (106). In spite of its small size, Massachusetts received a large share of immigrants.

${ }^{10}$ Antin was both an assimilationist and a Zionist. In the same article, she, on the one hand, professes a belief in "the national title of the Jews and in their right to govern themselves accordingly" and, on the other hand, argues that "spiritual affiliation with the Jewish nation is in no sense incompatible with complete civil devotion with the land of our adoption" ("Zionist's" 157).

${ }^{11}$ Mazur states that Antin's royalties for The Promised Land and speaking fees contributed to the purchase of the Scarsdale house (160).

${ }^{12}$ Antin's bodily imagery is a direct response to the organic rhetoric of eugenics movement. For example, Grant writes about "the Polish Jew, whose dwarf stature, peculiar mentality and ruthless concentration on self-interest are being grafted upon the stock of the nation" (16). 
${ }^{13}$ In her biographical sketches of notable women (Emma Lazarus, Margaret Fuller, Louise May Alcott, and Marie Bashkirtseff), Lazarus avoids any discussion of their stand on women's rights. For example, she never mentions the fact that Alcott was a proponent of women's suffrage and the first woman who registered to vote in Concord, MA, board of education election. Lazarus's account of Alcott's life focuses on her dedication to her family and on the sacrifices she made to support it. Even in her biography of Fuller, Lazarus skirts around the message of Woman in the Nineteenth Century, just mentioning in passing that Fuller's ideas were far ahead of her time (926) and stressing mostly her "fidelity and devotion" to family (927).

${ }^{14}$ Antin's family fell apart during World War I because of political difference between Antin and her husband, Amadeus Grabeau. Charles Jaret states that anti-German wave swept the country during the war. German Americans were often accused of being "un-American" and suspected of treason and sabotage (37). As Mazur points out, Grabau, a second-generation German American whose identity was deeply rooted in German language and culture, "believed Germany the victim of unjust condemnation" and strongly opposed U.S. intervention in the war (178). Antin, on the other hand, shared the anti-German sentiments of the American public and supported the war effort. Saltz refers to an interview in which Antin's daughter (who was seven in 1914) "recalls fierce political arguments raging daily until her parents, wanting to spare her the belligerent atmosphere, decided to separate" (87). Grabau's pro-German position was also one of the reasons why in 1918 he lost his job at Columbia University. In 1920 Grabau received a job offer from Peking University and joined its faculty as a Professor of Paleontology; he also worked as a Paleontologist for the Chinese Geological Survey. He moved to China and remained there for the rest of his life, visiting the United States once in 1933, which was also the last time when he saw his wife and daughter. According to Mazur, during this period of his life, Grabau 
made a remarkable contribution to stratigraphy and the dating of the Peking man; he was one of the first scientists who started to develop the theory of continental drift. Moreover, Grabau was instrumental in strengthening both Chinese geology and its ties with Western institutions. Grabau's ground-breaking works written in China re-established his reputation in American academia, and in 1936 the Academy of Sciences awarded him a prestigious Mary Clark Thompson Medal for geology and paleontology. Because of his failing health, Grabau could not travel to Washington, and Antin attended the banquet to receive the award as his wife (the couple never divorced). During World War II, Grabau survived Japanese occupation and the hardships of an internment camp. He died in Peking in March 1946. Antin outlived him by three years: she died of cancer in May 1949. 


\section{CHAPTER 3. EVA HOFFMAN IN THE LAND OF YEARNING}

The more I come to know about America, the more I have the dizzying sensation that I'm a quantum particle trying to locate myself within a swirl of atoms. How much time and energy I'll have to spend just claiming an ordinary place for myself! And how much more figuring out what that place might be, where on earth I might find a stable spot that feels like it's mine, and from which I can calmly observe the world. (Hoffman 160)

As a young adult, I continued to have a sense of uncertainty about my identity. When people I met would ask me where I was from, I wasn't sure what to say. Was I from Colorado, where I grew up, or was I from Czechoslovakia? (Potocky-Tripodi 4)

By all accounts, Eva Hoffman and Miriam Potocky-Tripodi are well-integrated immigrants and accomplished professionals. Hoffman, a highly placed New York editor and writer, arrived in Canada in 1959 when she was thirteen. Potocky-Tripodi, a professor of social work in Boca Ranton, Florida, came to the United States in 1969 at age seven. ${ }^{1}$ Their families left, respectively, Poland and Czechoslovakia for political and economic reasons as well as to escape anti-Semitism. Hoffman's and Potocky-Tripodi's autobiographical books offer an insight into the complex relations immigrant children have with their new country and into the persistent bond to their native countries. The quoted description of Hoffman's feelings during her college years is characteristic of the tone of her 1989 autobiography, Lost in Translation: A Life in a New Language. Despite her outward markers of success, she is still seeking a place where she would 
feel at home the way she felt in her native country. Similarly, Potocky-Tripodi, in her tellingly titled memoir Where is My Home?: A Refugee Journey (2000), states that the "feeling of being at home is foreign" to her (109) and that she has always thought of herself as "what sociologists call the 'marginal' person — the one who straddles two cultures yet is at home in neither; the one always on the edges looking in" (109). This chapter focuses on "the edges" in Hoffman's autobiography with occasional allusions to Potocky-Tripodi's short memoir.

Hoffman's nostalgic autobiography demonstrates that childhood places keep a strong hold on immigrants who were brought to America as children, complicating their attachment to the new place. A fruitless search for place is central to Hoffman's autobiography as she gradually concedes her disappointment and her trauma as well as her inability to establish placeconnectedness. Hoffman rejects her parents' version of the American Dream-accumulation of wealth—and re-fashions herself as a New York intellectual, but despite her success, she refrains from the triumphalist formula of immigrant narratives. Hoffman's autobiography moves from her early hopeful attempt to create a physical home to an eventual retreat from descriptions of places and of the feelings they evoke. As the subtitle of her book, A Life in a New Language, suggests, for Hoffman language almost completely supplants place as the setting of life and the arena of action. Place and language are not mutually exclusive, but they are not interchangeable either. Hoffman concentrates on language as a compensation for displacement and detachment. Hoffman is not alone in thinking that language might provide a complex home. Many theorists and writers assume that language is a vessel or a container that holds not only meaning but also human identity, a home if not for the body, at least for the soul, consciousness, the other. Michel Foucault refers to language as a "locus" that can be "inhabited by the other, the elsewhere, the distant" (111). Mikhail Bakhtin calls language "the living concrete environment in 
which the consciousness of the verbal artist lives" (288). When he argues that "the language is not an abstract system of normative forms" (293) and that instead of "a single unitary language, inviolable and indisputable" humans deal with multiplicity of languages (295), he consistently describes the function of language in spatial terms. He states that each language is "a world view, even [...] a concrete opinion" (271) that has an inside and an outside (289); that it can be "populated - overpopulated — with the intentions of others" (294). Referring to language as "a living, socio-ideological concrete thing," Bakhtin talks about an individual consciousness of a speaker as "living in" the language, with language lying "on the borderline between oneself and the other" (293) but also connecting the speaker with other people.

For immigrants, this borderline position of language can be an insurmountable obstacle, a wall that separates them from the world. Immigrants, even those who had studied the language of their new country before, start their adjustment process as outsiders to it, often lost in the incompatibility of meanings and the multiplicity of discourses. To illustrate how native speakers of a language can easily "pass from one [language] to the other without thinking, automatically," Bakhtin gives an example of an illiterate peasant who "lives in several language systems" and uses them appropriately according to the need: to pray to god, to sing songs, to talk to his family, or to dictate a petition to the local authorities (296). Making a home in a new language implies becoming an insider to its heteroglossia. Even highly educated immigrants are still "living" in their native language and cannot perform what Bakhtin considers to be an "inevitable necessity" of communication—cannot “actively orient” language (295).

The narrative structure of Hoffman's autobiography is based on the contrast between the Old and New Worlds. According to Madeline Levine, Hoffman's book is a classic example of the immigrant saga. Closely related to confessional narrative, this genre is characterized by 
"triumph over adversity"; its trajectory follows the narrator's "path leading straight from steerage to the comfortable berth of assimilation [...and] concludes with the heroine's fabulous success, well beyond all reasonable expectations" (218-219). Levine identifies in Hoffman's autobiography "the topoi of standard immigrant tale (e.g. the ship pulling away from the shores of the Old Country; the first glimpse of the New World; the early recoil from the strange new society and eventual appreciation of its merits)" (220). But Hoffman is not a typical immigrant heroine: she was reluctant to leave Poland and was not driven by an inspiring American Dream. Brought to Canada by her parents, she later refers to her emigration as to "a despairing and blind adolescent uprooting" (240). Like other Poles of the 1950s, Hoffman had limited knowledge of the United States and Canada, with snippets of information coming from Western radio broadcasts and films as well as from occasional letters and magazines that found their way across the Iron Curtain. Despite the anti-Communist stance of her family's circle and a certain allure of Western abundance, Hoffman was influenced by the official propaganda that portrayed America as a culturally inferior place. Moreover, Hoffman had a strong attachment to Cracow, the city of her birth. As a result, as Levine observes, the "emotional valence" of Hoffman's narrative is "deliberately inverted" (220), presenting the immigrant journey to the New World as an exile from paradise. In spite of her success, Hoffman cannot establish meaningful bonds to the places where she lives and works. When she leaves Poland, Cracow becomes a standard of both aesthetic and emotional comparison for the New World places, and the pain of this forceful extraction from her native country prevents Hoffman from becoming rooted and content in the new place.

The melancholy tone of Hoffman's book is characteristic of nostalgic autobiographies of childhood. As Kate Douglas argues, such texts idealize the past and express homesickness as 
well as "a longing to return home." At the same time, "the present is commonly perceived as less ideal and less desirable" (84). Written by adults, such autobiographies become "ideal vehicle[s] for nostalgic remembering" (85). In these texts, authors reconstruct and romanticize irrevocably lost time and place, performing an act of "cultural remembering" (86). The question of remembering has been creatively problematized in autobiographical studies. Thus, Eakin states that autobiography is "both an act of memory and an act of imagination [...so that] it is usually impossible for autobiographers and their readers to distinguish between them" (Fictions 6). Eakin suggests that not only the autobiographical truth is "an evolving concept" but also the author's self is "a fictive structure" (Fictions 13). James Goodwin attributes intentionality to the act of remembering. He points out that memory not simply recalls but "reconstructs and recreates, often more so with an eye towards the present moment of remembering than toward the past experience remembered" (12). In other words, autobiographers pursue more complicated goals than just remembering the past, and childhood autobiographers are creating not only a fictive childhood but also a fictive child. Whereas Antin presents herself in a heroic mode, Hoffman chooses nostalgia.

The searching, dissatisfied mood of Hoffman's book seems the opposite of the patriotic enthusiasm of Antin's autobiography. Commenting on the differences between Antin and herself, Hoffman argues that each of them is a creature of her time: while Antin's time gave her "a belief in self-improvement, in perfectability of species, in moral uplift" at the same time discouraging her from delving into the feelings hidden "behind the story of triumphant progress," Hoffman came to an America of multiplicity rather than of "central ethos" (164). It is true that post-World War II culture has been increasingly more accepting of ethnic diversity, but the "central ethos" and racial hierarchies still do exist in American society. It is the inclusion of Jews 
into the central ethos and the change of their status from non-white to white that benefited Hoffman the most. While anti-Semitism persists in the United States, Jewish immigrants, as well as other East Europeans, do not have the same urgent need to prove their ability to assimilate as Antin did or as migrants from Asia and Africa still do. Ignoring her privileged position in the complex racial hierarchy of America, Hoffman claims that her time demands acknowledgment of shifting perspectives and "cherishing of uncertainty as the only truth" (164). Without the need to conform to the master narrative of successful assimilation, Hoffman can reveal the pain of adjusting to a new culture, of searching for her place in a new language and a new world.

The structure of Hoffman's book is defined by the unresolved tension between her access to privileged places and her inability to form a meaningful attachment to them. According to Levine, the confessional narrative (and by extension an immigrant saga) "imposes its own rules of narrative construction." To justify so much self-exposure, this genre requires "the uplifting climax, the arrival at the present time from which the narrator, restored to health or wholeness, looks back upon a long and lonely struggle, and exultantly proclaims: 'I made it!'” (218). We can see this pattern in Jacob Riis's autobiography and in Anzia Yezierska's autobiographical stories, all of which culminate with a declaration of success that is achieved after overcoming numerous obstacles. ${ }^{2}$ Antin announces her conquest of America too early in the story, at the moment of her arrival in the New World, thus depriving her narrative of a meaningful ending. Hoffman reports enviable social achievements, but instead of building up to an emotional climax, she chooses to emphasize a lack of place-connectedness, thus diffusing the possibilities for a paradigmatic apotheosis.

\section{IMAGINING AMERICA IN CRACOW}

In many respects, Hoffman does follow the standard structure of immigrant narratives. Thus, she starts with the story of her parents and childhood and with a description of her home 
place. Hoffman was born after World War II into a family of Polish Jews, Holocaust survivors. ${ }^{3}$ Before emigrating to Canada in 1959, she lived in the ancient city of Cracow, which figures in the book as a place of infinite charm and beauty, a standard by which the author measures all other places. For Hoffman, Cracow is a city "full of history," where "layers and layers of reality" (39) provide her with "space[s] of happiness" (41). By the time of her emigration, she is old enough to have studied its streets and squares, "its medieval church spires and low, Baroque arcades" (39); she has learned to appreciate the beauty of old architecture and to walk its streets “in a state of musing, anticipatory pleasure" (38). Her family's position in the city is comfortable but far from privileged. The Wydras live "on the periphery of the city, in an area where urban houses give way to small rural cottages, patches of garden, and weed-covered no-man's-land" (13). Hoffman notes that their two-room apartment "is considered respectable by postwar Polish standards" mostly because they don't have neighbors who would use the same kitchen and bathroom (11). Hoffman shares a bedroom with her younger sister, whereas the so-called "first room" serves as a living room and their parents' bedroom, also offering a spare couch to frequent visitors. Nevertheless, nobody in the family thinks "that [their] apartment may be too crowded or that [they] might be suffering from invasion of privacy" because people around them have even less space (55). In fact, this "heat of human proximity" (56) seems to permeate not only the inside of apartments but also the whole life of the neighborhood in which people exchange gossip from their adjoining balconies (11), children play all day in the paved courtyard (11-12), and the Rumek family that "get[s] the first telephone on the block" often has "several people in their tiny foyer waiting to avail themselves of this instrument" (13). This is a picture of a modest but comfortable life within a closely knit community. 
Hoffman's idyllic childhood is complicated by two factors: her Jewishness and her parents' opposition to the Communist system — which lead to their decision to emigrate. Although each of these factors implied a potential threat to the family — harassment and imprisonment respectively - they do not mar Hoffman's happy memories. Except for the mention of a few instances of hostility, Hoffman hardly notices the pervasive anti-Semitism of the post-war Polish society. Even as a child, she is aware of her father's illegal and "risky money-making schemes [such as] buying forbidden dollars, or smuggling silver from East Germany" (14). Hoffman does not comment on the dangers that her father faced breaking the laws to support the family's existence "on the tenuous margins of the middle-class society" (13); she accepts his activities as a common survival strategy.

The first decade of Communist rule in Poland is marked by economic hardships, so Hoffman's father, like almost everyone in the country, is involved in "the constant, ongoing Game of outwitting the System," a game without which it is impossible to survive because "the normal job wage is hardly enough to feed a family, never mind to clothe them" (14). Wydra succeeds in his underground entrepreneurship and his efforts to shelter his family from privation. For the Wydras, these "illicit [economic] initiatives" (14) go hand in hand with political "subrosa convictions" (57) that resist the Communist ideology. From her parents and their friends, Hoffman learns about "the coexistence of the official and the popular wisdom, and the disparity between them" (63). This duality applies to all aspects of life, including perception of places. Although the Communist media always presents "the Soviet Union [...] as a sort of parent country, the center toward which the whole world leans" (59), Hoffman knows enough to realize that "if Russia is the center, it is a heavy and leaden center, a sort of black hole sucking bright energy into its sinister recesses" (60). In counterbalance to the picture of a benevolent and 
exemplary Soviet Union, another country, America, takes a pivotal place in Hoffman's imagination.

In the Poland of Hoffman's childhood, as in all other Soviet bloc countries, the propaganda picture of America was that of a war-mongering and "cruel place full of cold-hearted people" (60), but this image was contested by information from a variety of illegal sources. Hoffman recalls "neighborly huddles around Radio Free Europe broadcasts" (57), attended by trusted friends and held behind "carefully locked" doors (13). Because of the constant jamming of Western radio stations, only "snippets of information can be heard through the static" (13), but the eager listeners "usually accompanied [them] by undertone commentary" (57). In the ColdWar arms-and-space race between the two superpowers, many Poles root for the United States, hoping "that it will be the first to send a rocket into space" and to teach a lesson to "these barbarians," the Russians (60). However, politics is not the only, not even the major link to America. What attracts the Poles to the West is its consumer culture. Great is the excitement of Hoffman's mother when "American magazines [...] somehow find their way into her circle of friends" who then "pore over the clothes shown in those magazines [...and] make no distinctions between advertisements and other pictures" (22). The influence of American culture is sporadic but strongly felt. From "the Hula Hoop craze" (9) to the family pediatrician's "advanced and highly unorthodox methods of treating children, supposedly picked up during his years in America," the trends that reach Poland confirm the image of that distant country as a place "whence most advanced things unquestionably originate" (51). The geographic notion of America is rather loose: as Hoffman admits, "Canada in [their] minds is automatically subsumed under that category" so that both countries have for Hoffman and her family "the old fabulous associations: streets paved with gold, the goose that laid the golden egg" (84). Occasional parcels 
from an emigrant friend contain "material proof of American wealth"- a box of cocoa and nylon dresses that make Hoffman and her sister "the envy of the entire neighborhood" (60). Thus, information from official and alternative sources created in popular-and in Hoffman'simagination a picture of America as "an ambiguous land of vague fears and desires [...] the place where all the better things in life—cars, dollars, chewing gum, ballpoint pens—are endlessly available, even, [her] parents assure [her], to those downtrodden workers" (60), the staple characters of anti-American propaganda. Appropriately for the dawn-of-space-age time in which she is growing up, Hoffman sees America "whirling in interplanetary space like an enormous flying saucer" (60). This image also underscores the distance that separates Hoffman's world from the unattainable America of her fantasy.

Other media that competed with the propaganda image of America were films and music. Both provided young Poles with glimpses of the alluring Western culture and liberated their minds from the restrictive aesthetic canon of socialist realism. Hoffman describes her first American movie, a western with Kirk Douglas. Its imagery is "destined to become indelibly imprinted on [Hoffman's] memory"-not only because of the exotic place in which the action is set but also because of "the collective shudder and gasp that arise from the audience" at the rare sight of on-screen nudity (61). For Hoffman, as for other spectators in a "bedraggled Poland," Western cinema opens a window on an unfamiliar world that, as she admits, they cannot distinguish from fantasy. More than "all the drama of the plot," the material details of everyday Western life make Polish movie-goers ask one another, "Do you think people really live like this?" (102). On arrival in North America, Hoffman compares her new surroundings to images from those movies (102), so she must have chosen to accept life according to Hollywood as the true picture of America. 
Music that comes from the West also subverted propaganda stereotypes. Hearing for the first time "Rock Around the Clock," Hoffman feels its "electric sexy excitement [...that is] totally unlike the plaintive lyricism of the songs [one would] usually hear on the radio - mostly Polish and French." The appeal of rock music makes her doubt "that a country from which so many terrific things come can be as glum as the newsreels would have it" (61). Having learned early in life an alternative to the official ideology, at thirteen Hoffman is capable of making an independent judgment about Western music. Yet, no matter how attractive the Western world seems to be, Hoffman is reluctant to leave her home country.

Because Hoffman's Jewish family occupied a marginal status in Poland, compounded by their opposition to Communist system, their opportunities for advancement were severely limited. Therefore, emigration seemed to be the logical way out of a dead-end situation. The Wydras did not hide their anti-Communist convictions from their daughter so that Hoffman grew up being "no patriot [...because] she was never allowed to be one" (75). Nevertheless, Hoffman professes an absolute love for Poland as a culture and as a physical place, declaring that "no geometry of the landscape, no haze in the air, will live in us as intensely as the landscapes that we saw as the first, and to which we gave ourselves wholly, without reservations" (74-75). Hoffman emphasizes the power of the childhood emplacement and denies the possibility of bonding to other places.

This attachment to her native country makes her parents' decision to emigrate particularly painful for Hoffman. With many Jewish families leaving for Israel or America, Hoffman can also witness how lives become "torn and uprooted," how the security and comfort provided by modest homes disintegrate. She sees her friend Marek's apartment “transformed from a place in which people have lived cozily and for a long time into a space from which they are fleeing" 
(82). Hoffman shares the ambivalence towards these departures with other Polish Jews of the late 1950s for whom emigration is "neither entirely chosen nor entirely forced, [...rather it's] chosen and forced at the same time" (83). In a way, emigration is a chain reaction: when Jews start leaving Poland, it becomes difficult for the rest to remain "in this once again depopulated landscape" (83) and family after family leaves "only because it seems impossible to stay" (83). Hoffman's parents seem to be an exception to this reluctant mood. Having miraculously survived the war, they are keenly aware of the pervasive anti-Semitism and "have no doubts about the matter [of emigration]." For them, "Poland is home, in a way, but it is also hostile territory" (84). Hoffman's father accepts an offer of sponsorship from a pre-war friend now living in Canada, "which, he writes, is the real land of milk and honey, the land of opportunity, the place where you can grow rich and be happy. For [Hoffman's] father, this is an irresistibly alluring vision-to become a man of means in the American way, a man of substance" (84). Boris Wydra is resolute enough to stake everything on this promise; however, he cannot inspire his daughter with his optimistic vision of the future.

Hoffman shows no enthusiasm for leaving her country. As one of the reasons, she mentions the influence of Communist propaganda that often charges capitalist countries with indifference to high culture. Hoffman is a promising pianist, brought up in a tradition that gives musicians "sacred beast status; great pianists and violinists are endowed with the glitter of stardom and the prestige of high art" (67). Hoffman's parents have always supported her music studies because for them, as for many other Poles, their talented daughter's piano lessons “are part of $[\ldots]$ ambitions for giving their children the better things in life" (67). This path seems impossible in Canada whose propaganda image is that of "a 'cultural desert,' a country in which no one cares about fineness, or music, or art" (88). Her parents' decision to emigrate undermines 
Hoffman's confidence in her future as a musician. Hoffman might find rock music exciting, but she is afraid that neither she nor her piano will have a place in North America. In a way Hoffman's anxiety is justified, but her display of trust in propaganda seems uncharacteristic for an adolescent who was brought up in an opposition to Communist officialdom. In fact, Hoffman resists the idea of emigration because the prospect of leaving her home town is terrifying.

The main reason for Hoffman's hesitation is her strong attachment to and idealization of Cracow. As the departure time draws near, she is overcome by the "sense of impending loss" (86) that heightens her perception of familiar and ordinary places, such as "a nondescript patch of garden, which $[\ldots]$ holds a bit of [herself]" (88). This vital connection to her native place forces Hoffman to view emigration not as a new beginning, which is typical for immigrant narratives, but as an ending. In a conflation of time and space, emigration marks for Hoffman the end of her childhood and an irretrievable loss of a place where she felt at home. Judging by the chapter titles ("Paradise," "Exile," and "The New World"), Hoffman sees her journey from one continent to another as a forceful expulsion from an idyllic existence. It is easy to believe that Hoffman has had a happy childhood but hard to imagine that she is unaware of the problems that are forcing her parents out of Poland. Marianne Hirsch, who came to the United States from Eastern Europe at the same age and almost simultaneously with Hoffman, admits being "bothered by the contradiction between [Hoffman's] Edenic construction of Cracow [...] and the prehistory of her parents' hiding in a branch-covered forest bunker" during the war. Hirsch asserts that Hoffman bases "her construction of her narrative and her world, of her self" on the denial of the city's tragic history and on the displacement "of the anti-Semitism she admittedly still experiences." Hirsch considers this evasiveness about the past to be "an understandable childish strategy of survival" (77), but it does not explain Hoffman's apathy about the future. 
Such a gloomy outlook is not necessarily typical for emigrant children. For example, on the transatlantic voyage Hoffman meets Janek, a boy who is going to live with his father "in a small pioneering outpost in [...] Ontario." Janek is excited about his new life and expects it to be "practically a Karl May adventure" (90). Apparently, book-based images of North America are capable of filling a child with enthusiastic anticipation, but for Hoffman, there is neither certainty nor promise in the future. She has no American Dream to sustain her during the traumatic departure from Cracow or during her disappointing encounter with America.

\section{OUT OF PLACE IN NORTH AMERICA}

Hoffman's involuntary emigration is not inspired by a dream vision of America or high hopes for the future. Consequently, she embarks on the journey with apprehension rather than excitement. Hoffman's despondent mood colors her perception of the North American continent. Its nature, which by common standards is considered beautiful, does not appeal to Hoffman because it is "ineffably and utterly" different from the familiar sites of her childhood. The vastness and emptiness of the landscape make her think that she is "in the middle of nowhere" (93). Apparently, Hoffman is not the only person who is overwhelmed by the outlandish sight. When the "tall and monolithic" buildings of Montreal appear on the horizon as "massive, gray shapes against the cloudy sky," the view does not excite any enthusiasm on deck. Instead, passengers "look at the approaching city wordlessly." The physical embodiment of their dreams turns out to be "more powerful than any figment of the imagination" (95). The absence of words that would correspond to the perceptions and emotions of the moment signals a traumatic realization of loss and displacement as well as suddenly thwarted expectations. Such reaction might seem strange from the mid-twentieth-century European immigrants. Unlike uneducated shtetl Jews of early twentieth-century immigration, they must have seen photographs of American cityscapes and should have known what to expect on arrival. But, as Hoffman 
acknowledges later in the book, literature does not prepare a visitor "for the broad and the intimate spectacle of the actual country confronting him" (184), and the same certainly goes for information obtained from other sources. When Hoffman's first glimpse of the Canadian shore "returns all [her] sense of loss to [her] like a sudden punch in the stomach" (92), it is an emotional reaction triggered in part by aesthetic dissatisfaction.

Apart from the realization of the loss, the moment of arrival in the New World is traumatic because this is when immigrants face the uncertainty of their future. It is interesting to note that all three discussed authors who came to North America as children realize their parents' emotions only in hindsight. Hoffman focuses on her own impressions, using mostly "I" and sometimes switching to "we" to speak for the whole family. She never differentiates her parents' or her sister's reactions from this totalizing whole. Only once does she report seeing an expression "of naïve hope" on her parents' faces when they are listening to the encouraging rant of a fellow traveler on the train (101). Similar inattentiveness can be observed in Antin who is always speaking about herself and only in passing mentions her mother's thoughts about the family's poverty (184). Also in retrospect, Potocky-Tripodi comments on a family picture taken soon after their arrival in New York, "standing on the verge of their new life in America." She notes the resemblance between this photo and Ellis Island pictures taken in the early 1900s, capturing similar moments when fresh immigrants "fac[e] an unknown future, possess[...] only the hope for the better life" (87). She also observes that it is the only photo she has ever seen of her mother smiling (88). It is not surprising that Potocky-Tripodi's mother did not smile in her pre-emigration picture because smiling for the camera is not part of East European mores. That she has not since learned the American way of reacting to the prompt "Cheeeeese!" reveals a lot both about the hopeful moment of arrival in the new country and about the difficult decades that 
followed. ${ }^{4}$ For the most part, immigrant parents' vulnerability seems to go unnoticed by their children.

The first sight of the new country does not correspond to Hoffman's expectations and makes an unfavorable impression that in turn determines the subsequent pattern of her relations to places in Canada and the United States. Hoffman's vision of America is a combination of cinematic and print images that are superimposed on the familiar characteristics of East European plains. Starting with the inauspicious arrival in Montreal and the train ride to Vancouver, Hoffman keeps comparing everything she sees to her beloved Poland, to "the friendly fields, the farmyards of Polish countryside." But the terrain outside the train window seems to her "flat and monotonous [...] dull and formless." Even the spectacular landscapes of the Rockies leave her indifferent because "[t]hese peaks and ravines, these mountain streams and enormous boulders hurt [her] eyes [...and] soul" (100). The anxious mood of the travelers is exacerbated by the bleak weather that meets them in Vancouver where "[e]verything is the color of slate." The only detail that connects the Wydras to the previously imagined America is the enormous car that takes them to their hosts' home, but the house is to her "a matter of utter bafflement." For her Polish eyes, a detached house "surrounded by a large garden $[\ldots]$ doesn't belong in a city — but neither can it be imagined in the country." Hoffman is surprised by the "pruned and trimmed" look of the garden and by the "improbably smooth and velvety" lawn (101). The interior of the house, although spacious and richly furnished, seems "oddly flat, devoid of imagination, ingenuous" (102). Only the kitchen with its "fabulously functional appliances" and the bathroom where "toilet paper [...] comes in different colors" correspond to Hoffman's mental image inspired by the Western movies she watched in Poland (102). However, the few recognizable details do not fall into a comprehensible picture or evoke a 
positive emotional response. As a reaction to her unintelligible surroundings, Hoffman embarks on a myth-making process.

In an attempt to add coherence to her world, Hoffman performs what she calls "a ritual" of lying in her letters back home. Without being taught, she intuits the complex reasons that compel immigrants to conceal, exaggerate, or invent facts: they do it "to impress and convince their friends and relatives - and probably even themselves - that their lives have changed for the better." Another purpose of these lies, one especially urgent for Hoffman—is "to fend off [...] nostalgia" (116) for the places they left behind. What Hoffman does not acknowledge is that her letters perpetuate a mythical image of America where instead of alienation, a newly arrived immigrant can report, as she does, a "blooming" social life with a succession of parties (116). Out of all characteristics of the new place that shocked her on arrival, Hoffman selects a garden, albeit belonging to someone else, as a detail that would domesticate the forbidding cityscape: "I am sitting at a window looking out on a garden in which there is a cherry tree, an apple tree, and bushes of roses now in bloom. The roses are smaller and wilder here, but imagine! All this in the middle of a city" (116). Like a conversation about weather, a letter about a garden avoids painful topics while maintaining a semblance of communication. For the writer, such letters also alleviate the pain of existence in a city that contrasts the canon of beauty that Polish immigrants might have.

As with nature, Hoffman has a mental image of what a city should be, a standard based on her beloved Cracow. Vancouver, which at the time of Hoffman's arrival still has "an outpost flavor" (134), loses the comparison. Like many immigrants before and after them, the Wydras start their life in the poor neighborhood of a big city. In Hoffman's part of Vancouver, the Main Street is 
a ramshackle, low-built part of town that seems a no place, thrown up randomly, without particular order or purpose. There are sprawling parking lots, patches of narrow, wooden houses, and nameless one-story cement structures, which look as haphazard as if the city itself has turned into a junk-yard here. (134)

The nature around Vancouver does not compensate for the ugliness of the city. Although the ocean and the surrounding mountains are considered breathtakingly beautiful, they "look like a picture postcard" to Hoffman. She rejects this "forbidding" landscape because it is not human sized or penetrable (134). Neither does Hoffman profess attraction to the public places of Vancouver; in fact, she hardly notices them. For her, the city lacks "the strata of human, as opposed to geological age" or "the pulse of life" that make Cracow an exciting and happy place. Hoffman's frame of reference and her concept of a city are so different that she cannot properly see whatever "doesn't fall into any grid of mental imagery" (135). Only many years later, coming from New York to visit her parents, Hoffman has “the eyes to see [Vancouver's] flowerfilled gardens, and hear small kindnesses under the flat Canadian accents" (151). As long as her parents keep living in Vancouver, the city remains a home of sorts to Hoffman, her "shtetl-onthe-Pacific" (247), but still this city "will never be the place [Hoffman] most love[s], for it was here that [she] fell out of the net of meaning into the weightlessness of chaos" (151). This loss of grounding is exacerbated by the financial hardships that the family has to endure.

Contrary to the Wydras' expectation of prosperity that to some extent motivated their emigration, they do not become rich overnight. Hoffman's father turns out to be a poor businessman. Having outsmarted first the Nazis and then the Communists, Boris Wydra came to Canada believing that "it shouldn't be hard to get rich in this country," a conviction confirmed on their first train ride to Vancouver when a passenger speaking Yiddish tells them about a 
Polish Jew who became a millionaire producing Polish pickles (100). In reality, to the great surprise of his family, Wydra seems to have lost his previously never-failing resourcefulness. He is clueless when "confronted by this amiable Vancouver, by its civility and its shaved lawns." Not only does he not understand what it is "that prevents him from becoming rich and successful," but he also blames himself for his family's miserable conditions in a place where "many people have made good." The belief in the possibility of easy advancement is so strong in immigrants' minds that they feel guilty about their poverty and inaptitude. Hoffman identifies this "corrosive logic" and this "gut-eating guilt" as "the other side of the New World dream" (128-129). Like most immigrants, the Wydras cannot see any flaws in the American Dream or in their motives for emigration, and even if they do, they are not willing to admit it.

Madelaine Hron confirms the pervasiveness of this attitude among newcomers who "internalize the myth of success and are compelled to play down their suffering of immigration [...] so as to conform to the image of the successful immigrant" (20). This is what Antin does in her autobiography when she subordinates her emotions to a high rhetorical goal and only hints at the falsehood of her writing in private letters. It takes Hoffman years to extricate her vision from the tenets of pre-conceived beliefs imposed on her by her parents. Only in hindsight does Hoffman realize that her family came to Canada "at an odd time — between waves of emigration, when there seems to be no support system to ease the 'newcomers' first steps." Without such support, immigrants are on their own, "and the most obvious elements of every exchange present themselves as hurdles to be deciphered and mastered" (125). Hoffman does not notice that this absence of support services makes her family's situation analogous to that of the Antins and of other early-twentieth-century immigrants who could not expect help from anybody except close relatives and friends. ${ }^{5}$ Eventually, Hoffman's parents save enough money for a down payment 
on a modest stucco house-a "minimally furnished cell of the American Dream" (125). They open a junk store in the basement, "but it doesn't turn out to be the beginning of a fabulous success story; [Hoffman's] father won't build a furniture empire, won't be a real estate baron, won't buy fancy cars every year" (127). For the Wydra family, the contrast between their poverty and the surrounding abundance of material goods becomes almost unbearable.

A pauper in the land of ostentatious consumerism, Hoffman is filled with "yearning and revulsion" at the sight of the tempting "profusion of objects" in the stores. To fight this feeling of deprivation, she decides to "stop wanting" and make herself "immune to desire" (136). She retreats into the world of intellect where material possessions, such as "big houses with large yards and swimming pools, and cars and many skirts and blouses and pairs of shoes," are replaced by "internal goods"—reading, learning, and other "programs of self-improvement" (136-137). For Hoffman, knowledge and understanding are paths to owning "the entire world" (137). On the one hand, Hoffman's determination seems to be an indicator of optimism. On the other hand, she frankly admits that her detachment and her "carefully trained serenity" were not "entirely genuine." Rather, they covered "a caldron of seething lost loves and a rage at the loss" (139). Hoffman also realizes that humans cannot live in a world of pure intellect; they have to "exist in actual houses, in communities, in clothes"; they need "the shelter of a specific place" and "a comfort of being a recognizable somebody placed on a recognizable social map" (139140). Thus, Hoffman acknowledges the significance and interdependence of the two kinds of place - social and physical; while she learns how to advance in the former, the latter keeps eluding her.

Like many immigrants, Hoffman sets the goal of success through education. Her family's poverty adds "an extra edge to [her] ambition" and strengthens her desire to do well in 
school, "to make [herself] a steel breastplate of achievement and good grades" (157). Defining upward mobility as a movement from wrong to right places, Hoffman wants "to get out—and get in"- to acquire a high social status. Hoffman does not want to be stuck in the Bowery-the place where she would "end up if [she didn't] do everything exactly right" (157). Hoffman becomes a precocious overachiever who astonishes the locals with her speedy acquisition of and her excellence in the English language — as well as with her opinions. When interviewed by newspaper and radio reporters, the adolescent Hoffman declares that "New York is the real capital of the United States [...because] Washington just has the government [...but] doesn't have the excitement." Without any fear of offending the listeners, Hoffman pronounces Canada to be "the dullest country in the world [...] because it is the most conformist" (133).

Although the adult Hoffman attributes these arrogant opinions to her "fourteen-year-old innocence" (133), the notion of Canada as a wrong place — not the dream America after all— compels her to move to the United States after high school. Eventually, Hoffman acquires an American Dream of her own, and a specific one at that: she wants to be a "New York intellectual." Warned that it is "a rather exclusive club," Hoffman is not discouraged (244). Her goal is defined by a professional and social status and grounded in a specific geographic location. It is also supported by the efforts of her struggling parents, who see education as a ticket to a better life for their daughters. But Hoffman eventually drops her parents' plight from the narrative. The readers never find out if the Wydras are still running a junk store when their daughter receives a doctoral degree from Harvard. With "a tinge of egotism" similar to what Handlin notices in Antin (Foreword xii), Hoffman focuses more on her own professional success and less on her family's story or family places. 
After Hoffman reports her initial disappointment in her first place of residence, her descriptions of places become more and more sketchy. Place becomes for Hoffman less a physical location than a linguistic abstract one, a sign of social acceptance and a marker of identity. She moves from Canada to the United States and keeps moving from place to place without establishing ties to any of them. Out of all colleges available to a bright student on the North-American continent, Hoffman chooses Rice University in Houston, TX—“the real America" as she thinks then, "not having any way of knowing that [she is] in a particular region of it, at a specific and rather curious time in its history" (171). Her mental picture of this faraway city is a combination of Wild West imagery "overlaid by photographs in Time magazine showing tall buildings, oil rigs, and other signs of an economic boom" (161). Hoffman's first impression of the campus is favorable: it seems to be "a friendly and manageable place," and her dorm room, although "plain and purely functional — a bed, a closet, a desk— [...] fills [Hoffman] with a sense of well-being, because it's a room like everybody else's, an equalizing space" (172). Attachment to this likeable place seems possible, but soon its uniformity and equality prove to be an illusion.

At the start of her college years, Hoffman believes that students don't have to be "aware of social distinctions" and that she can be "just whoever [she is]." Only later does she discover that "the social landscape which seems so homogenous at first is divided into complex configurations that everyone recognizes through subtle signals which are quite lost on [her]" (172), but she is not discouraged and becomes an eager student of these nuances. Hoffman compares her attempts to understand American culture to the actions of "a naturalist trying to orient [herself] in an uncharted landscape, and eyeing the flora and fauna around [her] with a combination of curiosity and detachment" (173-174). This image is reminiscent of the early 
settlers' exploration of the wilderness. Finding herself in a new social landscape, Hoffman declares the same desire to study her surroundings that was driving her predecessors, thus establishing the continuity of immigrant experience. At the same time, Hoffman attempts to transcend the immigrant culture that seems focused solely on material success, to maintain her initial commitment to intellectual achievements, and to bridge the gap between the abstract and the physical America.

Hoffman's social success does not result in attachment to places because her ambition lacks both roots and a geographic destination. Although she keeps accumulating outward markers of advancement— top grades, scholarships, prestigious graduate programs—she longs not so much for material goods as for "the comfort that comes from being cradled by continuity, the freedom from insignificance" (159-160). Significance for Hoffman seems to mean being rooted and comfortable in an actual place, or experiencing no disjunction between mental and physical places. This is why she envies Henry Adams, for whom "America has been a fitting habitat for the mind rather than just a complex of ideas, a field for significant action rather than a launching pad for individual ambition, for making it." Hoffman admits the absurdity of envying someone who, like Adams, is born into a life of privilege, so Jewish-American intellectuals, Alfred Kazin and Norman Podhoretz, are more of model to her, their opposing political views notwithstanding. Hoffman envies them because "their journeys from the outer boroughs to Manhattan felt long and arduous to them, but at least they knew where the center was, they felt the compelling lure of its glittering lights. Their dreams were American dreams; their desires were inscribed in the American idiom" (160). ${ }^{6}$ For Hoffman, the difference in journeys is, of course, both geographical and linguistic: to reach the glittering lights, she, unlike Kazin and Podhoretz, has to traverse not only the border of a borough but also of a language. But even her 
mastery of English cannot compensate for the lack of an America Dream of her own: since it was her parents' vision that brought her to America, Hoffman feels as if her desires, "when freed from their protective covering, are forceful, and they are as unchanneled as an infant's id" (160). The need to channel her desires and to find meaningful goals compels Hoffman to place herself in the context of her generation of Americans.

Hoffman's move to Houston turns out to be liberating because she finds herself in the "college country" (171) of the 1960s that welcomes an aloof foreigner as its own. However, Hoffman cannot wholeheartedly share the feelings and aspirations of her American counterparts. Her longing for acceptance and stability goes against the grain of their restless youth culture: I want to live within language and to be held within the frame of culture; they want to break out of the constraints of both language and culture. Perhaps those constraints have been too severe; perhaps that is the root cause of this revolution. But their oppressions have not been mine, and therefore their fight — against the established terms of a middleclass, American reality_cannot be mine either. (194)

Here again Hoffman is presenting language as spatial and equates it with a dwelling place. The security of one's linguistic home can be taken for granted by people who live in their native tongue but is still a distant goal on the horizon for Hoffman, as are the comforts of middle-class life that stifle young Americans. Moreover, Hoffman cannot rebel against American conventionality because her life is ruled by conventions of a different, much less liberal or prosperous culture in which families stay together to survive and advance in society. Hirsch offers additional insights into immigrant youths' attitude towards intergenerational conflicts, observing that they cannot "afford to alienate [their] parents quite as much as [American teenagers] can" because in immigrant families parents are going through a similar adjustment 
process. Hirsch recalls her mother being "unhappy about everything 'American' [...and needing] protection and support, not adolescent rage and rejection." It is possible that Hoffman has to "negotiate $[\ldots]$ the contradiction between sixties adolescent rebellion and the strong familial bonds forged by the experience of emigration" the way Hirsch does (85). Still, the changes brought about in the 1960s create an atmosphere more conducive to overcoming immigrant alienation than the xenophobic early 1900s.

Whereas Hoffman's predecessors had to conform to the dominating monocultural model, Hoffman benefits from the multiplicity and multiculturalism that her rebellious American friends advocate. This democratic educational system and "a democratic ideology of reading" do not consider an immigrant from Poland to be "an outsider poaching on other's property." On the contrary, she is "welcomed on equal terms" (183) and accepted by her American colleagueswhich does not mean that Hoffman accepts their culture as her own. In fact, she finds it hard "to give up the condition of being a foreigner" (202). The giving-up seems to be a fluctuating rather than a linear process so that the author reports almost simultaneous conflicting emotions. On the one hand, "through the democratizing power of literature [...she] begin[s] to feel at home in America" (183-184). On the other hand, she is constantly trying "to figure out [...] where [she] belong $[\mathrm{s}]$ in this America that's made up of so many sub-Americas" $(202) .{ }^{7}$ The seeming paradox of Hoffman's narrative might have its roots in the difference between abstract and physical place. Literature can provide an intellectual refuge for a young scholar but cannot help her forge emotional ties to streets and houses.

\section{LOOKING FOR A HOME IN THE LANGUAGE}

In the absence of place-connectedness, language and the process of translation become the focus of Hoffman's attention, the path to and the locus of her assimilation. Language acquisition described by Hoffman is more complex than just learning grammatical structures or 
accumulating vocabulary. Bakhtin contrasts the abstract, "unitary" form of language to its stratified and heteroglot, "living" form (288). It is the former that non-native speakers learn from textbooks, but it is the latter that carries meanings, "the intentional, that is, the denotative and expressive dimensions" that are realized in specific situations. For outsiders, "languages become things, limited in their meaning and expression" (289). Becoming an insider to a language is Hoffman's goal.

First, Hoffman has to deal with the impossibility of "transport[ing] human meanings whole from one culture to another," when, for example, terms that characterize human behavior and personality, such as "adventurousness, or cleverness, or shyness [...] are measured along a different scale and mapped within a different diagram" (175). This incompatibility of languages that gives the title to Hoffman's book has been described by other immigrant authors. Thus, Stanislaw Baranczak, a post-1968 immigrant from Czechoslovakia, suggests that the problem of translation "lies not in the mere tedium of rummaging through dictionaries and laboriously substituting one word for another." Similarly to Hoffman, he notes that two different languages are never mirror reflection of each other; their seemingly corresponding parts never exactly match. The semantic range of supposedly equivalent words in fact only partially overlap; or a meaning may be expressed by three different synonyms in one language and five in the other; or a word may have no counterparts in the other language at all; or the emotional tinge of a word may disappear in its foreign equivalent. (248-249)

The task of translators becomes even more complicated when they move up from the level of separate words to “phrases, sentences, verse lines, stanzas, paragraphs [...or to] the nation's accumulated historical experience, which is reflected in words' and expressions' elusive 
connotations, not to be found in any dictionary." Baranczak asserts that a translator's "most brilliant effort may result at best in an approximation that is more ingenious than other approximations" (249); however, for an adolescent who is learning the language of her new country, approximation is not good enough.

Although outwardly Hoffman picks up the English language quickly and does well in school, the dissonance between her two languages keeps haunting her long into adulthood. Equating language with place, Hoffman presents this linguistic disparity as homelessness. Because "the totality of the world and mind [are] coeval with the totality of the language" (217), living in the language that is not hers from birth makes Hoffman's physical world incomplete and her perception of it deficient. Paradoxically, Hoffman feels this way about English well past the early stages of learning it, when she is already teaching literature at the University of New Hampshire (216). Even with such high mastery of the language, Hoffman does not feel at home in it; although she can claim "every territorial prerogative" in using the written language, her reality still has gaps that she tries to fill in with "bits of colloquial idiom" (217). Hoffman still has "unworded" images cross her mind, which she compares to living "in a windy, unfurnished imagination" (216). Her goal is "to make a comfortable habitation there, fill it with few household things, some comfy, everyday objects [...and] to add a bottom to the language that [she] learned from the top" (217). Hoffman uses concrete domestic terms to describe her proficiency and comfort with the language, as if her English protects and grounds her the way a home should. Potocky-Tripodi also acknowledges a complex relationship with her two languages, remarking that "although [her] English had become much better than [her] Czech, [she] always had some awareness that English was not [her] native language." In spite of her high mastery of English, she "yearned to spend a day of [her] life hearing only Czech" (5). 
Hoffman makes this wrenching remove from a native language her subject, suggesting that language acquisition—or the travel between languages—-might well be her only home.

For all immigrants, language is the locus of both home and exile, but immigrant authors feel their linguistic displacement more acutely because language is their professional tool. Commenting on Joseph Conrad's story "Amy Foster," Said observes that Conrad portrays the loss of home and language "as irredeemable, relentlessly anguished, raw, untreatable, always acute" ("No Reconciliation" 93). Some immigrant writers choose to present this painful process humorously. Thus, Aksenov notes that in immigration

[t]he mother tongue has undergone a process of shrinking: from a bubbling ocean, it may turn into a placid pond or, to the contrary, a language used to be perceived as the fancy amenity of a certain elite may become a gigantic mixture containing all sorts of things. In exile you dive and emerge from one language to another all day long. ("Lungs and Gills" 234)

What follows from Aksenov's aquatic metaphor for literary exile is the need to "develop a certain type of gills in addition to [...] lungs" ("Lungs and Gills" 235). This "amphibious" quality is necessary for the survival of immigrant writers who are placed in a strange element-a new language where the familiar meaning is lost. In his critical study of several immigrant poets, David Patterson argues that "[e]xile, human homelessness itself, lies in the violent divorce between word and meaning, between sign and substance" (174), which means that "the place of exile is language" (190). Consequently, immigrant poetry reflects the authors' need to bring together "word and meaning" and to put both in a correct place (142) — which can become the poet's home. Patterson argues that "home is precisely the place where word and meaning join to make life hale, whole, and holy" (154), and since poetry is a means of bringing together word 
and meaning, a place where "we find a confluence of the exile of the word and the word of the exile," poetry becomes "the place of human dwelling" (174). By extension, any writing can emerge as a locus of habitation, and language can serve as a means of adjusting and connecting to a new place.

Hoffman was not a writer when she was forced to dive into an unfamiliar language, but in graduate school she chooses English as her major - at the cost of giving up her piano career, as if the more abstract language of music cannot provide her with the home she wants to secure in the English language. To show how torn she is between these paths in life, Hoffman relates an internal argument she has with herself in two languages. In Polish, she recalls her passion for music, whereas in English she insists on her duty to herself, on the need "to figure out how to live [her] life" (200). In this dialogue, readers can hear an echo of Hoffman's early fears about the secondary place of high art in America as well as a lack of confidence in her abilities as a pianist. Hoffman thinks she will "end up giving concerts in small towns and colleges" without making a significant contribution to "the same tired repertory" (200). Hoffman does not give a definitive answer as to what motivated the change of career paths. It could have been her ambition - a desire to climb to a higher position in life than that of a small town pianist—but it could have also been the need to bridge the gap between word and meaning and to communicate to the world in a more concrete manner than through the language of music. In addition, Hoffman's decision to go for a Ph.D. in English brings her to Cambridge, Massachusetts, a place that reminds her of her first home.

During her year at the Yale Music School, Hoffman visits Boston, the first American city that promises a possibility of an emotional bond and makes Hoffman realize that it is the place where she wants to pursue her academic career. At first sight, the city "answered some deep 
desire" (201) in Hoffman, and she walks "the crooked, cobblestoned streets of Cambridge as if [she] were tentatively trying on a new home" (202). Paradoxically, in this most European of American cities, Hoffman believes her friends who assure her that she has "landed in the real America at last" (202)—an America that is different from gaudy shopping centers or standardized suburbs. Harvard's rarefied intellectual atmosphere as well as its physical characteristics - the modesty of Harvard Yard, the wood-paneled rooms, and the tweed-jacketed professors (202) — seem to be a reward for years of abstention from consumerism and for Hoffman's retreat into the realm of language. Eventually, she does “crack the last barrier between [herself] and language" so that words not only become "beautiful things" but also acquire "a complexity of meaning [...and] the sonorities of felt, sensuous thought" (186). Moreover, a doctoral degree from Harvard, the most prestigious of American universities, lands her a job in her dream place-Manhattan. However, neither being at home in the English language nor living on the most expensive tract of real estate in the country creates for Hoffman connections to physical places.

Readers of Hoffman's autobiography don't learn much about her work as a writer and editor for The New York Times or about her teaching at Columbia, but they do get an account of the author's far-from-simple feelings about her place in this high-powered world:

America, I think. This goddamn place. [...] This goddamn place is my home now, and sometimes I'm taken aback by how comfortable I feel in its tart, overheated, insecure, well-meaning, expansive atmosphere. I know all the issues and all the codes here. I'm as alert as a bat to all subliminal signals sent by word, look, gesture. (169) Hoffman's word choice, simultaneously intimate and profane and her paradoxical feeling of uneasiness with being comfortable in one's home place can be traced back to the "real" home of 
Hoffman's childhood. In spite of the perfect "fit" with her surroundings, Hoffman is constantly aware of the existence of "the other place" or "another place [...] which renders this place relative" (170). No matter how comfortable or prestigious Hoffman's current place is, it never becomes the absolute center of her universe - only another "base of a triangle" (170). She feels disconnected from her surroundings because the city of her childhood and her past still keep a strong hold on her imagination.

\section{REVISITING CHILDHOOD PLACES}

Hoffman's life in North America is troubled by a yearning for Cracow and by a desire to revisit it. Her first attempt to go back, in 1968, is thwarted by the anti-Semitic campaign of the Polish Communist government that forces the few remaining Jews out of the country and keeps the door closed for occasional would-be visitors. When she does get a visa in 1977, her home town is a center of anti-regime demonstrations and of the government's retributive violence. In spite of the tensions, Hoffman's recognition of the place and of its feel is immediate. Starting from the mannerisms of her co-travelers on the train, with the whole

arrangement of this scene, the men bending toward the woman, their voices, with an edge of sarcasm and provocation, the knife slicing into the sausage - all of this will be forever more natural, more uncannily natural to [her] than the immaculate commuter folding The Wall Street Journal neatly in half on the Long Island train. (233)

Reciprocal instant recognition occurs when Hoffman's Cracow friends easily pick her out of the crowd of arriving passengers, identifying her "casual clothes made of good materials" as foreign (233). In the lives and apartments of her Polish friends little has changed during the previous eighteen years because "[n]othing ever changes," and Hoffman is greeted by the sight of the same furniture and by the familiar "acrid, sweetish smell of cigarettes mixed with perfume and bales of fabric, which in [her] girlhood was the atmosphere of female eroticism" (234). Over 
traditional hors-d'oeuvres—-"plates of cheeses and herring and ham"—and vodka, the conversation still revolves around "the fabulous, unattainable, terrifying West" and around Russia's advantages over America, this time in the field of education. Hoffman finds it impossible to explain either "the complexity of American educational system" or the vagaries of her personal life. In the oppressive Communist society, family is a unit of survival, a crucial source of mutual support, so for Hoffman's Cracow friends, her separation and imminent divorce disprove her claim that "everything is just fine" (235). As a result of her visit to Poland, Hoffman acknowledges the mutability of relationships, attitudes, and places as an important distinction of the West.

Hoffman's return to Cracow—-the place of her childhood—cannot take her back to the happy past, so the disjunction between time and place continues. On arrival, Hoffman recollects the place of her dreams whose images have been "encoded in some regions of [her] memory" and knows her way around without a map or guide (232). Hoffman finds her beloved city "remarkably unchanged" albeit tainted by industrial pollution (238). She recognizes its landmarks and the pastime of its inhabitants, but cannot recapture "the childhood knowledge"the moments of bliss that she had experienced there before (239). What Hoffman does gain from this visit is a release from the past. The place that loomed so large during her adolescent years in America now becomes a "block of [her] story," finally diminished to "the right proportion" (241). Continuing the literary analogy, Hoffman compares this new insight to revising a manuscript "backward from the middle" to the beginning in order to "to go on with the rest" (242). Moreover, Hoffman can now distinguish the dream Cracow, "with images folding into one another, luminous and somnolent and heavy with the promise of revelation," from the real Cracow, "palpable and vivid." She visualizes the two Cracows as contained within a glass sphere 
and safely isolated from her present life (242). The glass sphere brings to mind a paper weight, suggesting domestication of a previously mysterious location. The magical city of Hoffman's childhood is now both literary material and an innocuous household object that keeps her manuscript from being scattered. However, the demystified past does not secure for Hoffman a place in the present, partly because she cannot resolve the what-if question.

Having experienced the involuntary uprooting as an immigrant child, Hoffman keeps wondering what would have happened if her family had stayed in Poland. Hoffman imagines how predictable her life would have been: the events would have followed a pattern of "an intelligible sequence," with a different "ratio of change to stability." She would have had "the invigorating moral clarity that comes from knowing which side is in the right and which is in the wrong." In a culture that has a much stronger frame and that "holds the individual personality more firmly in place," she would not have felt alienated from the concerns of her generation the way she did in America. Nevertheless, she would have emigrated anyway during the 1968 antiSemitic purges, only it would have been her own conscious adult choice rather than her parents' decision (240). ${ }^{8}$ When a friend asks Hoffman whether she has ever regretted her emigration, Hoffman denies having any compunctions or even identifying with the person she would have been in this imagined other life. Nevertheless, the readers hear a tone of regret at her having, at the moment of emigration, neither "accretions of sorrows" (240) that would have pushed her out of Poland nor a spirit of adventure that would have motivated her to seek an ideal in another country.

Potocky-Tripodi shares Hoffman's longing for her native place as well as her desire to go back and restore the rudely severed connection. She gives a poignant account of her visit to Prague after a twenty-six-year absence. Yearning for her childhood home, she feels connected to 
her birthplace by "fleeting images" that keep passing through her mind, and when she finally goes to Prague in 1995, she wants to find the embodiment of her memories and to confirm "that those places [she] imagined really did exist and still do" (37). Walking through the streets of Prague brings Potocky-Tripodi into "a continuous state of hyper awareness" when all her senses—physical sensation, hearing, taste, and smell—are heightened (37-38). Her search reveals the paradox of return: on the one hand, she does not see any familiar sights; on the other hand, "nothing is unfamiliar." Each time she recognizes a place, she feels "electrified" and "the thin threads" that have bound her to Prague turn into "a live current" (37) — a striking description of place-connectedness in physical terms.

In her attempts to secure the newly discovered roots, Potocky-Tripodi absorbs not only the sight and the feel of the place but also "the essence of Czech culture" (38) and "peculiar, lilting inflections" of the Czech language (37). After several visits to Prague, Potocky-Tripodi starts feeling less a stranger there than in the United States, except for her "rather limited ability to express [her]self in Czech." Language stands as a barrier between her "and those who never left" (109), but she hopes to find the "common bond" that connects her to these people. PotockyTripodi studies the faces of subway passengers, "searching for commonalities" and realizing, similarly to Hoffman, that she "was born to be one of them- $-[\ldots]$ it should be [she] who sits so casually on this train, seemingly oblivious to all the symbols and meanings it holds. Instead, history made [her] an observer - a witness to [her] own possible other life" (39). Indeed, Potocky-Tripodi places her childhood emigration in the context of the cataclysmic events that pushed her family out of Czechoslovakia - the Holocaust, the Communist take-over in the late 1940s, the Soviet invasion of 1968. If she and her parents had had a pre-emigration vision of America or a dream of success, she does not mention it in the memoir. Potocky-Tripodi seems to 
accept her place, even if it does not feel like home. By contrast Hoffman, after visiting the place that she had never wanted to leave, keeps speculating about the meaning of emigration and the shapes of the American Dream.

\section{AMERICA OF IMMIGRANT DREAMS}

As an immigrant child brought to Canada by her parents, Hoffman did not have to make the momentous decision; neither did she have a fully formed American Dream of her own. However, interaction with other immigrants — from Poland and Brazil—allows Hoffman to transcend the limitations of her circumstances and experience. These contacts also demonstrate Hoffman's transnational position of belonging both to American and to Polish cultures. Thus, in the early 1980s, she encounters numerous newcomers from her homeland when another wave of emigration sweeps out of Poland, this time "courtesy of General Jaruzelski, and yet another turnabout - the declaration of martial law_-in the perpetual drama of Polish events" (255). This group of immigrants arrives in America “on great gusts of energy, desperado drive, wit, and malice” (255). They are politically charged and still reeling from the Communist regime's crackdown of the opposition. In her relations with these Poles, Hoffman finds herself on the cusp of two cultures, a position from which she can comprehend both sides but can never explain either: she understands but does not share the new Polish immigrants' assessment of the situation in Poland as hopeless. At the same time, her level-headed and reasonable interpretation of American ways sounds naïve to the New York Poles who cynically see "gossip and intrigue" everywhere (255-6). Although they all seem to be speaking the same language, the nuances of American life often get lost in translation as familiar words change and even lose their meaning when applied to realities of a different culture.

Because it took Hoffman years to formulate her own American Dream, she can appreciate the role it plays in immigration. With her friends, Hoffman seems to be re-living her 
own early disappointments and witnessing the death of the American myth after a clash with reality. Getting together in a house with a "dubious-smelling staircase," in an apartment with a “small and dingy kitchen," Hoffman's Poles still remember how back in Poland they used to say, "Ah, America!" when they saw something that was "cool and groovy, and just as it should be" (259). This imagined America has not materialized on the American soil and now recedes further into the realm of abstraction. The ideal becomes the subject of sarcastic conversations in which immigrants mock their illusions:

Ach, old man, don't worry. [...] Someday you'll get there, and then you'll see what it's like. Tall men in cowboy hats, producers throwing deals at your feet, a swimming pool in every penthouse, and a TV with a remote control in every room... I tell you, it's quite a country, America. (259)

Such pronouncements help Hoffman recognize the importance of the American Dream for supporting human aspirations. Hearing her friends complain that people "used to be able to emigrate to America" and that now there is no place to emigrate to, Hoffman realizes that "the fabulous America of people's dreams [...is a] place the mind can turn to for fantastic hope" (261). She understands both her friends' need for an ideal and the origins of its imagery. As Hoffman watches these "variously disaffected or nostalgic or dislocated" people in their fitful late-night wanderings around New York, she realizes that their discomfiture stems from the cinematic and literary nature of their dream:

And maybe $[\ldots]$ they're looking for the America they imagined $[\ldots]$ as the essence of excitement itself, a mythological excitement. Perhaps they're still searching for the New York they knew only from the novels of Dos Passos and Truman Capote and funky 
movies featuring neon-garish streets and implausible chases along rainy sidewalks in the night— the New York that proves so elusive now that they're here. (258) Hoffman contrasts the lofty standards of dissatisfied Poles to the practical goals of Maria, an immigrant from Brazil, "who nurtures no fantastic hopes" and does not deal with abstractions. She has escaped from the slums where "people no eat. They have no hot water." In spite of all the hardships of immigrant life, Maria is happy to be in a country where "if you work hard, you get a few things" (261). The difference is in social distinctions and in the scope of expectations: Maria makes a living by cleaning other people's apartments, including Hoffman's, and is satisfied with the way her life has improved in her new country. If you want a better (not necessarily the best) life, "it's still America you emigrate to-this all too real America" (261). Although this America does not always fit the mental image that immigrants might have had, it still offers enough lure to keep even the disillusioned Poles from returning to their home country. Unlike Poland with its closed system and predictable outcomes, America is a place where "almost anything can happen," which means that it is still a place of hope and opportunity. Another reason for their staying is, as Hoffman suggests, the matter of scale: Poland is a small stage, "nearly a box, a sort of Punch and Judy show" whereas America offers a performance stage "large enough, and indeterminate enough, to stand in for the world" (259). What Hoffman is not acknowledging is that it is also a matter of influence that America as a superpower exercises in the world.

In her assessment of paths open to immigrants in America, Hoffman disregards race and class factors that can facilitate or hinder upward mobility. Hoffman rightfully notes that America is a lot more welcoming to immigrants from her part of the world than it used to be only a few decades earlier (195). Early-twentieth-century Jewish immigrants were considered an 
undesirable, alien race, incapable of assimilation. According to Brodkin, through the 1940s, Jews were "excluded from mainstream corporate management and corporately employed professions, except in the garment and movie industries, in which they were pioneers. Jews were almost totally excluded from university faculties" (33). After World War II, society's attitude towards Jews has become more tolerant and accepting. Brodkin argues that it happened partly due to "America's postwar economic prosperity and its enormously expanded need for professional, technical, and managerial labor" and partly due to "an expanded notion of whiteness" that now included Jews and other East Europeans (37). Immigrants arriving from Eastern and Southern Europe in the 1950s certainly benefited from this liberalization of racial criteria, but groups that are considered non-white did not. What Hron says about Czechs is also true about Poles or Jews: "because of their unmarked appearance, [they] do not encounter the same type of discrimination and racism" as non-white ethnic groups, such as Haitian or Maghrebis (189). Demonstrating blindness to her own race privileges, Hoffman claims that recent changes in American society almost devalued her and other immigrants' assimilation achievements.

Contrasting her experience with that of earlier generations of Eastern European newcomers, Hoffman asserts that she started her Americanization "in the least snobbish of societies and the most fluid of generations. It's that very mobility—upward, horizontal, and of some topological varieties not described in classical symmetry—-that makes assimilation an almost outmoded idea" (195). This statement might be true of white East Europeans but is not applicable, for example, to immigrants from Central and South America whose alleged inability to assimilate is often perceived as a threat to genuine Americanness. In a way, Hoffman is right when she says that she was spared "the pain of early immigrants, who were kept out of exclusive clubs or decent neighborhoods" or when she believes that she can go as far as her abilities and 
ambitions take her "and be accepted there." However, when she proclaims that "[t]he only joke is that there is no there there" and that in contemporary America "the very notion of outside and inside" is outdated (196), she is speaking from a vantage insider position. Ironically, such pronouncements indicate that the author has indeed successfully assimilated. Contrary to Hoffman's claims, many racial and ethnic groups, both immigrant and native-born, are keenly aware of divisions in society. There are outsiders in America, and there is a "there" for black Americans who are trying to escape or transform inner city neighborhoods as well as for immigrants who hope to secure a foothold on the job market. Most likely, if Hoffman, instead of advancing to a series of the most prestigious places in North America, had remained in her parents' junk shop, there would have been a "there" for her, too. At the same time, Hoffman's word choice_ " "there" rather than "here"_-implies some distance even from an insider's position.

Hoffman believes that her "acute sense of dislocation" is characteristic not only for immigrants but for many Americans of her generation. They also had "the equally acute challenge of having to invent a place and an identity," except that Hoffman, unlike her American counterparts, had no "traditional supports" (197). Although it is hard to compare the acuteness of challenge that different people experience in adolescence, Hoffman is contradicting her own description of her suffering as an immigrant child when she equates it with the growing pains of her American coevals. Since Hoffman's generation of Americans is by no means uniform, some of them might have lacked "traditional supports" or felt a sense of dislocation and alienation as acute as those of an immigrant. However, Hoffman seems to be talking not about neglected and abused kids, for instance, but about the rebellious fellow students whom she befriended in college, especially when she declares that "exile is the archetypal condition of contemporary 
lives" (197). Hoffman bases this last observation on the high mobility of upper-middle-class Americans. Since people of this elite group have a guaranteed place in the world, they can boast, as Hoffman does, of an ability to "land in any city and within hours figure out how to get around it, use the metro, and find a good neighborhood restaurant and a decent midpriced hotel." She does acknowledge the privilege of being American, or living "in an imperial center whose currency is the international standard and whose language is the Esperanto of the modern world" (251). However, she forgets that not all Americans, to say nothing of residents of less powerful countries, have "learned to read the signs and symbols governing the typology of the contemporary world" (251). When applied broadly and generally to human condition, Hoffman's viewpoint seems simplistic and even arrogant. Yet, this stance serves a rhetorical purpose in Hoffman's narrative - to rationalize her lack of place-connectedness. By declaring herself a postmodern nomad, Hoffman might be trying to explain her inability to form an attachment to a specific geographic location.

Hoffman, while following the model of immigrant autobiography in general, refrains from climaxing her story on any of her numerous accomplishments. Although she calls her Harvard doctoral degree "the certificate of full Americanization" (226), she diffuses the triumphal possibility of the graduation ceremony by bringing in Marek, her Polish adolescent love. His visit at Harvard not only opens the door for Hoffman's memories of her childhood places, but also seems to shatter her carefully cultivated connections to her American surroundings. In Marek's presence, Hoffman becomes "keenly aware" of the linguistic and psychological distance between herself and her husband. Although "touched by [her husband's] niceness," she realizes that she has never been able to "read the language of his feeling." His "light [and] erudite conversation" that Hoffman has always admired now seems to be carried on 
in a foreign language (227). The English language suddenly loses its meaning, and the home provided by Hoffman's acquired language disintegrates. Thus, the moment when the immigrant author could have uttered an exclamation of victory becomes for Hoffman one among many moments of alienation and displacement.

When Hoffman professes feeling at home anywhere, it is an equivalent of professing having no home - not in the sense of having no place to live but in the sense of being unattached to places emotionally. In the concluding paragraph of the book, Hoffman acknowledges America as "the place where [she's] alive," but the location that at that moment stands for the whole New World is not her own dwelling but her friend's Cambridge garden. It is also an abstract intersection of time that "pulses through [her] blood like a river" and of language in which, finally, words perfectly fit the objects they name. Moreover, when Hoffman urges herself to be "here now," she does it "in the faintly ironic tones in which the phrase is uttered by the likes of [her]" (280). This category is meant to include sophisticated intellectuals who are both aware and skeptical of the buzz words of their time. "The likes of [her]" could also include immigrants whose connection to place is never unconditional or complete.

In her work written during the twenty odd years that have passed since the publication of Lost in Translation, Hoffman keeps returning to places of her past and to the road not taken. As soon as the Wall falls, she rushes to Poland and travels through Eastern Europe observing and recording the epoch-making changes, publishing as a result Exit into History: A Journey Through the New Eastern Europe (1993). At the same time, Hoffman takes on the monumental task of comprehending the fate of Polish Jews during World War II. Her thoughtful analysis, meticulous research, and numerous interviews with both Holocaust survivors and their Polish neighbors produce Shtetl: The Life and Death of a Small Town and the World of Polish Jews (1997), a 
poignant account of Polish-Jewish relations from medieval to our times. In her 2004 book After Such Knowledge: Memory, History and the Legacy of the Holocaust, Hoffman explores the uniquely complex psychological position of Jewish children (now in their middle age) whose parents survived the war. The heroines of Hoffman's novels, Illuminations (2009) and Appassionata (2011), are classical pianists, living the life that could have been Hoffman's if she did not chose English over music.

In her autobiography, Hoffman both models and undermines the classical immigrant saga. While using the traditional binary structure that juxtaposes the Old and the New World, the author reverses the value of these places. Rather than presenting her journey from Poland to North America as liberation from a restrictive and hostile regime, Hoffman voices the trauma of loss and displacement. She is unable to establish connections to new places because she perceives them through the prism of her nostalgia, her emotional and aesthetic attachment to her native Cracow. However, her fixation in Cracow is based on a mirage. The city with its centuries-old accumulation of culture is indeed one of the most beautiful in Europe, but it also has a tragic history and exists in a bleak present. As a child, Hoffman idealizes Cracow, ignoring its oppressive Communist regime and its anti-Semitism.

Hoffman's connection to American places is complicated for yet another reason: her emigration was not inspired by an uplifting American Dream of her own. Vicariously, she shared her parents" dream of "gold-paved streets" and of getting rich quickly—the wrong kind of dream that cannot stand against the shock of reality. When Hoffman does formulate her dream, her goals are intellectual rather than material and language acquisition is a substitute for developing place-connectedness. Hoffman's professional success allows her to move to the most desirable 
and prestigious places in America but does not result in emotional bonding with them. She builds a house out of academic achievements, carves for herself a niche in the intellectual realm, but still cannot find a physical place that would mean for her as much as Cracow once did.

Hoffman's return to her childhood place demystifies the city and evokes complex emotional response as well as speculations about the meaning of the American Dream. She realizes that imagining a life in a better place supports hope and motivates change, even if the embodiment of the ideal can never be found. Hoffman seems to accept and eulogize her unattached mode of existence, paradoxically elevating it to the level of an unproblematic, even desirable human condition.

Hoffman takes a postmodern stance on the meaning of the immigrant journey. In her narrative, emotional fulfillment is not predicated on social accomplishments but is always deferred. Instead of paradigmatic per-aspera-ad-astra triumphalism, Hoffman offers a wistful close look at an asymptotic process of assimilation, of never becoming an American. Hoffman's focus on intellectual possibilities of America and her version of the American Dream tie her to Vasily Aksenov and Edward Limonov, authors discussed in the next chapter.

\footnotetext{
1 "Potocky-Tripodi" combines the author's family name "Potocky" with that of her husband, “Tripodi." Potocky-Tripodi’s choice of profession was motivated by her immigrant experience. Her book Best Practices for Social Work with Immigrants and Refugees is a comprehensive manual in which she urges her colleagues to acquire "specialized knowledge of the unique issues of these populations" (3).

${ }^{2}$ On the last pages of his autobiography, Riis, after many years in America, is visiting his home country, Denmark. He falls ill and has to spend weeks in bed until one day he sees through an
} 
open window a sail ship "flying at the top the flag of freedom, blown out on the breeze till every star in it shone bright and clear." The sight of the American flag brings joy to Riis's heart and tears to his eyes. It makes him realize that he "had become American in truth." Like a NewTestament character, he is healed by this apparition and is able to arise from his bed and go home (443). It is interesting to note how Riis's narrative demonstrates the need for distancing oneself from a place to confirm a sense of belonging.

3 "Hoffman" is the author's name by marriage. Her family's last name is "Wydra," and the unAmericanized spelling of her first name is "Ewa."

${ }^{4}$ While her husband who knew English found a job as an engineering technician, Mrs. Potocky "took on the typical occupation of immigrant women — the garment worker" (4-5). Similarly to Antin's and Hoffman's parents, the Potockys worked hard to support their daughter's education. ${ }^{5}$ Services available to immigrants in Canada might be different from those in the Unites States, but in general immigration historians note a lot of similarities between the two countries. For example, David M. Reimers and Harold Troper observe that "public debate has focused on many of the same issues, and responses have been similar" (15). Canada also experienced a drop in immigration during the Great Depression; after World War II, the Canadian public was "hesitant about allowing in those who stood first in line to get out of postwar Europe-Jews and Slavs. In a public opinion poll taken in October 1946, almost half of those surveyed voiced disapproval of allowing Jews into Canada. This number was higher by far than the number opposed to any other immigrant group except the Japanese, who were recently defeated in the Pacific and against whom racist wartime propaganda had been vicious and effective" (20). In Canada, liberalization of immigration laws and procedures occurred in 1967, "paralleling American reforms of two years earlier" (37). 
${ }^{6}$ Potocky-Tripodi also admits envying "those imaginary others who [she assumes] feel at home much of the time" (109).

${ }^{7}$ Potocky-Tripodi reports similar ambiguous attitude towards her new country. Because she has spent most of her life in the United States, Potocky-Tripodi feels guilt and "some shame for not feeling at home here" in the country whose people have been, "for the most part," good to her (109-110). Potocky-Tripodi's memoir is short and focused on her return visits to Prague rather than on her adolescence in the United States; it does not relate the hardships that stand behind this laconic qualifier, "for the most part." From the preface to Potocky-Tripodi's book on social work we can glean some details about the author's family: "a mother who didn't speak English after ten years of living in the U.S.; a son who refused to speak Czech and therefore did not speak with his mother at all; a daughter who continually translated both language and American norms; a family that didn't talk about feelings." This situation confounded social workers and therapists who were trying to help the Potockys but in their ignorance of cultural differences made the matters worse (xv-xvi).

${ }^{8}$ During her visit to Cracow, Hoffman learns that out of 40,000 Jews who resided in Poland until 1968 only 5,000 remain, not including many people of mixed descent. As a result, Jews have become "exotic [...], an almost extinct species [...and] an object of friendly jokes and nostalgia and superstition" (239). Significantly, Hoffman reports the phenomenon but does not dwell on its causes. As a child protected by her family, she may have not noticed the anti-Semitism surrounding her. As an autobiographer, she chooses not to explore the events that lead to another exodus of Jews from Poland. Hoffman returns to the fate of Polish Jews in her later books, Shtetl and After Such Knowledge. 


\section{CHAPTER 4}

\section{VASILY AKSENOV AND EDWARD LIMONOV IN THE LAND OF FREEDOM}

I was pleasantly surprised to learn that the indulgence of the American academic community knows no bounds. (Aksenov SMB 60)

We thought the USSR was a paradise for the mediocre, we thought it would be different here if you were talented. Fuck no! (Limonov Eddie 150)

These statements demonstrate the contrasting opinions existing among immigrant writers and artists who left the Soviet Union following their cherished American Dream. In the case of Vasily Aksenov and Edward Limonov, it was a dream of intellectual freedom and of a cosmopolitan connection among cultures. During the suffocating conformism of Brezhnev's era, many intellectuals emigrated to the West in hopes of having their books published or of their art work exhibited and appreciated, believing that their art and writing belonged to a broader realm of Western culture. Yet, most of them found unexpected similarities between American and Soviet literary scenes and were unable to adjust to the demands of the literary and art market. Aksenov is a rare example of a writer who found what he was looking for and settled down to a comfortable life as an established author and college professor. Although he did not leave his home country of his own will—as he puts it, he was "booted out of Moscow" (SMB 3)—Aksenov did choose to come to the United States rather than to make his home in Europe because he was inspired by a strong positive notion of America as a place of creative freedom as well as a place that welcomes immigrants with open arms. Aksenov’s 1985 memoir, In Search of Melancholy Baby, rationalizes 
the author's decision to come to America, relates his first years in the United States, and measures American reality against the American Dream ideal. Limonov's It's Me, Eddie voices the anger and bitterness of a Russian immigrant poet who does not receive any recognition in America. Subtitled "a fictional memoir," it is based on the main events of the author's life but features a protagonist who is unable to take root in the new place because his talent remains unclaimed. ${ }^{1}$

While this chapter focuses mainly on Aksenov, I offer a contrast between Aksenov's memoir and Limonov's fictional memoir in order to highlight one of the central concerns of this dissertation: the link between the American Dream and place-connectedness. Adult immigrants' perception of American places and their ability to establish meaningful bonds to the new place is determined by America's reception of the immigrants, and by the degree to which it meets their expectations. In the case of former Soviet writers whose idealized image of America is centered on a belief in creative freedom and cosmopolitan cultural values but lacks an understanding of the mechanisms of the free market, the unpredictable world of competition and self-promotion seems unwelcoming, even hostile. Limonov's book demonstrates how the need to fight for recognition and literary success stand in the way of an immigrant author's adjustment to physical place and to establishing a positive emotional bond with the new country. Aksenov's facilitated transition, on the other hand, allows him to feel at home in America.

I will apply to these texts one of the meanings of cosmopolitanism, defined by Robert Spencer as "a disposition — one characterized by self-awareness, by a penetrating sensitivity to the world beyond one's immediate milieu" (4). This understanding of the term and its application to art and literature characterized the outlook of Cold-War-era Soviet intellectuals - in contrast to economic and political dimensions of the term maintained by Communist ideology. ${ }^{2}$ As Clark observes, in the 1930s, the term cosmopolitanism "was rarely used in the Soviet press and did not have particularly positive connotations; in the late 1940s, the term emerged to prominence as the 
pejorative in the official campaign against things Western in general and Jews in particular (5). Consequently, people who were attracted to Western culture and took a stand in opposition to official ideology often fashioned themselves as cultural cosmopolitans and rather naïvely ignored the ambiguity and the political implications of the term.

Aksenov's memoir provides an insight into the evolution of the American Dream and the cosmopolitan ideal shared by many Soviet intellectuals of his and later generations. Aksenov both continues and challenges the Russian literary tradition of commenting on America and of shaping its contradictory image for Russian audiences. He traces the origin of the romanticized image of America and exposes the influence of numerous cultural layers (such as Russian literature, Soviet propaganda, American literature and art). Aksenov contests his own previous contribution to Russian Americana, his 1976 travelogue "Kruglye Sutki Non-stop," admitting to some misconceptions and illusions. Nevertheless, Aksenov's fascination with America persists through the first few years of exile and colors his perception of American places. Limonov's book does not dwell on the provenance of the protagonist's American Dream, but his pre-emigration poem "My Nacional'nyj Geroj" offers a picture of an imagined cosmopolitan cultural scene where an émigré poet from the Soviet Union is acknowledged and celebrated. Although Limonov's poem carries the cosmopolitan ideal to a narcissistic extreme, it does dramatize the expectations of Soviet creative intelligentsia as to their rightful place in the Western culture.

Aksenov's American Dream has cultural, rather than political orientation, which explains the political naiveté of Aksenov-immigrant as he records his fresh American impressions in his memoir. His American Dream lacks the traditional immigrant vision of immense riches or endless opportunities for "making it." His narrative lacks both the rags-to-riches trajectory and an account of hardships. It registers little nostalgia for the left-behind motherland and no strong emotion evoked by American places. On the contrary, Aksenov maintains the tone of objective observation 
and inquiry, weaving historic facts and literary analogies into the story of his experience. Aksenov applies an analytical approach to his American Dream, to his encounters with new places, and to his process of adjusting to American life. He registers some initial disappointment but does not have to renounce his dream altogether. Instead, Aksenov reconciles the two visions of his new country-his pre-emigration ideal and the real country he finds himself in - which allows him to find a comfortable place where he can feel rooted and content. However, this successful adjustment cannot be attributed solely to the author's adaptability.

Aksenov is a fortunate immigrant who does not have to start at the bottom and gradually come up in life. During the first five years of immigration, Aksenov publishes works written in the 1970s, such as The Burn, Our Golden Ironburg, and The Island of Crimea, a collection of plays, a collection of stories, and his first novels written in America, Bumazhnyi Peizazh [Paperscape] and Skazhi Izium [Say Cheese]. ${ }^{3}$ In Search of Melancholy Baby is translated into English immediately upon completion and published by Random House in 1985; its Russian text is published in 1987 by Liberty Publishing House. Such recognition certainly confirms Aksenov’s belief in America’s hospitality and mitigates for him the pain of displacement. Moreover, as a well-known and wellconnected writer, Aksenov has a niche waiting for him on arrival and joins American academia as a guest lecturer and a college instructor. From a university campus, America is seen differently than from a slum neighborhood or from a junk shop in immigrant quarters, so, for the most part, Aksenov's book upholds the author's initial idealized image of America as a country that opens its doors and provides opportunities for newcomers from all over the world. Aksenov does not acknowledge the privileges of his social status, and his book differs from accounts of less fortunate Soviet immigrants who also came to America in search of intellectual freedom but were unable to find an outlet for their creativity and their thoughts. 
Edward Limonov's road to recognition was longer and more arduous. America appeared to him as an inhospitable and hostile place to which he never adjusted. A samizdat poet well known in Moscow bohemian circles, he emigrated in 1974. According to Zakhar Prilepin, the author of the writer's biography, Limonov left the Soviet Union to avoid the alternative-forced collaboration with the KGB. Neither was he willing to make a name for himself by joining the efforts of antiSoviet propaganda in the West. Limonov had hard times publicizing his skeptical views of the bourgeois way of life, of the capitalist system, and of the Unites States in particular. After a Soviet newspaper reprinted an article in which Limonov voiced his disappointment in America, the author was fired from the Russian-language émigré newspaper where he worked as a proof-reader. He had to take a variety of menial jobs — as a mason, a butler, a tailor — to survive. Written in 1976, his first prose work, Eto Ya, Edichka [It's Me, Eddie], which discredits the myth of welcoming America, was declined by thirty-five U.S. publishers and finally saw the light of day in France (Prilepin). The biography pictures Limonov as unappreciated and rejected by America.

Information from other sources contradicts some claims of Limonov's authorized biographer. For example, Eto Ya, Edichka might have been turned down by some American publishers, but its first American edition (by the American Index Publishers) came out in 1979, the same year the book was published in Paris, and was soon followed by a second edition. It is true that it took a while for English-language publishers to catch up with the scandalous émigré author, but in 1983 the English translation of the book appeared in London and New York. During the 1980s, It's Me, Eddie, as well as subsequent Limonov's novels, sold many copies in English and other languages. More importantly, although Limonov might have been pushed towards emigration by KGB persecution, he was as full of high hopes as any willing emigrant. Shortly before his emigration, Limonov wrote a prose poem “My Nacional'nyj Geroj” [We the National Hero], which is, according to Olga Matich, "[c]hildish and toylike in its fairytale images of success" and of the 
author's conquest of the West (527). Like Limonov, his protagonist Eddie, is looking for glory and for a place in the pantheon of influential cultural figures rather than for contentment and stability. It is the disappointment in this fairytale American Dream that fuels his anger and prevents him from establishing place-connectedness in America. Eddie rejects middle-class values and way of life, continuing in America a marginal existence similar to his former life on the margins of Soviet society — with significant loss in readership and prestige. The contrast between the rage of Limonov's protagonist and Aksenov's calm and humorous tone testifies to the constituent power of the American Dream in immigrant authors' acceptance of American culture and in their connectedness to American places.

\section{A LOVE AFFAIR WITH AMERICA}

Aksenov's memoir relates the origins of his American ideal that was common to most postWorld-War-II Soviet intellectuals. Although Limonov's protagonist does not provide respective details of his learning about America, Limonov was influenced by the same cultural forces that shaped Aksenov's American Dream. Before coming to the United States, Aksenov was well-versed in many aspects of its culture and had an ardent fascination with America. As other Russians of his generation, he was familiar with Hollywood movies, with jazz, and with books by American writers, from communist sympathizers such as Dreiser to the newly translated Hemingway and Faulkner. After moving to Moscow and becoming a member of the literary elite, Aksenov had better access to sources of Americana, such as music and films, than an average Russian. Aksenov was among the few select intellectuals who were allowed to travel abroad and get a first-hand experience of other countries. ${ }^{4}$ In addition, his good command of the English language helped him keep abreast with the latest literary events in America. Thus, in 1976, he translated for publication E.L. Doctorow's 1975 novel Ragtime. This exposure to the best of American culture outbalanced whatever effects anti-American propaganda might have had on a son of the "enemies of the people" 
who had experienced first-hand the duplicity of the official rhetoric. ${ }^{5}$ Having survived an orphanage and Siberian exile, Aksenov embraced the sights, the sounds, and the literary images of a different world whose very existence gave hope to Soviet "Thaw" intellectuals. His 1975 visit to UCLA presented an opportunity to encounter the object of his passion, but the euphoric two months were not enough to dispel the myth of the dream America. Only living in the United States as an immigrant was Aksenov able to take a closer look at American places without rose-colored glasses.

Aksenov's love affair with America, as he reports in the memoir, dates back to his WorldWar-II childhood when the Unites States was celebrated as an ally whose Lend-Lease program helped the Soviet Union to win the war. For many people of Aksenov's generation, no amount of carefully selected negative news coverage or propaganda lies could efface the image of America as the country that had supplied food for starving Soviet children and equipment for the Soviet Army. Forever grateful to the United States that, according to Aksenov, "provided a lifeline during a period of total death" (SMB 14), the Russians imagined America as "a country of fabled riches and munificence" and viewed Americans as "close relations" (SMB 15). Moreover, America gave the Russians "a vague hope for change after the war was over" (SMB 14). Indeed, this wartime international connection allowed Soviet people a brief contact with a wider world, with America in particular. $^{6}$

Aksenov was exposed to the formerly unfamiliar American culture when Hollywood films brought from Germany as spoils of war started showing in theaters around the country. In the memoir, Aksenov recalls the effect of these films that diluted the stream of "ideologically pure [Soviet] pictures" (SMB 17). He and his friends watch each American movie ten or fifteen times and speak to one another "entirely in quotes" from these films (SMB 18). Moreover, this first glimpse of America, of its places and people, inspires Aksenov and other youngsters to alter their clothes and change their life style. In an interview with Inger Lauridsen and Per Dalgård, Aksenov 
describes his life in the early 1950s, when he and his "crowd" of students at Kazan State University "went around in torn clothes, listened to jazz, $[\ldots]$ lived in a commune, $[\ldots]$ painted abstract pictures, [...] wrote all kinds of hooliganish poems, [...] drank, danced the 'boogiewoogie."' As Aksenov states, Kazan students had not yet heard about the Beat poets and did not know that their life style paralleled that of American Beatniks (Lauridsen 16). Although jazz and abstract paintings have an unmistakably American origin, Aksenov and his friends were fashioning themselves after Russian Futurists. This mixture of influences is characteristic of the time when Soviet intellectuals were starting to discover two previously forbidden cultural spheres: Western art and the early 1900s Russian avant-garde heritage. With a new access to Western sources, Aksenov would soon consider himself a follower of "the America cult" (SMB 19).

In the rigid hierarchy of Soviet society, a privileged geographic location, such as residence in the capital, gave a person numerous economic and cultural advantages. For Aksenov, visits and the eventual move to Moscow opened the door to information unavailable to ordinary Soviet people. Moscow became his real home, the place where he changed careers from medicine to literature and enjoyed success as a writer. Here he was introduced to new aspects of American culture by young people belonging to the exclusive circle of the Soviet elite, such as children of high-ranking KGB officers. With a shock, Aksenov learned that these "Stateniks," or "America lovers," listened to the forbidden Voice of America, used "sophisticated English vocabulary ('darling,' 'baby,' 'let's drink')" and emulated American fashion, wearing “jackets with huge padded shoulders, tight black trousers, and thick-soled shoes" (SMB 13). Flaunting the austere and highly regimented Soviet style of clothing, these "stilyagi" were, in Aksenov's opinion, "the first dissidents" (SMB 18). More importantly, these Moscow acquaintances gave Aksenov access to jazz, “America's secret weapon number one," that provided an aesthetic window on the outside world (SMB 18). Aksenov and other jazz aficionados listened to Willis Conover's jazz program on VOA, 
swapped pirated jazz records made out of X-ray plates, copied music on "antediluvian recorders and play $[\ldots]$ it over and over at semiunderground parties which often end $[\ldots]$ in fistfights with Komsomol patrols or even police raids" (SMB 18). The Communist Party sensed that jazz was "polluting" the minds of young Soviet people, presenting a danger to the established order.

This early, albeit fragmented exposure to American music and culture informed what would later become Aksenov's American Dream. Looking back on the years of his youth and evaluating the significance of jazz in his life, Aksenov extolls the improvisatory nature of jazz and its "refusal to be pinned down." These qualities made jazz anathema to both the Communists and the Nazis but provided Aksenov and other rebellious young people with a "relief from the structures of [their] minutely controlled everyday lives, of the five-year plans, of historic materialism." For them, jazz was "more than music." It was "a platonic rendezvous with freedom" (SMB 203). Moreover, for the young people of Aksenov's generation, jazz was a defining element in their picture of America, "a kind of a golden glow over the horizon when the sun went down, that is, in the West, the inaccessible but oh so desirable West" (SMB 18). It is from snatches of music and cinematic images that they "pieced together" (SMB 19) a picture of America that was centered mostly on the freedom of creative and intellectual expression — an ideal unattainable in Soviet art and literature that were closely monitored by the Party.

In the liberal atmosphere of the early 1960s that gave Soviet writers some room for experimentation in style and content as well as for a narrow range of dissenting political opinions, Aksenov pushed the limits of the permissible. His prose, as Mark Lipovetsky observes, developed an "inclination towards irony and lack of stylistic inhibitions [...] overstep[ping] the bound of ideological loyalty" (107). When in 1963 Aksenov was reprimanded for transgressing the rules, he chose to repent rather than to lose his traveling privileges. Explaining to Western readers what such acts of repentance meant to Soviet writers, J.J. Johnson compares Aksenov's case to that of 
Galileo - an appropriate analogy because Aksenov's forced confession was by no means sincere. ${ }^{7}$ Neither did it result in political conformity. According to Konstantin Kustanovich, Aksenov contributed to the writers' efforts to fight neo-Stalinist tendencies of the government. In 1966-1967, he signed a letter protesting the trial of writers Sinyavsky and Daniel as well as Solzhenitsyn's letter to the Presidium of the Congress of Soviet Writers "in which [Solzhenitsyn] wrote about the persecution of writers under Stalin and the continuing suppression of literature in the present." Aksenov also "participated in an anti-Stalinist demonstration in Red Square"—without any serious consequences (29-31): he continued to publish and travel for a few more years. ${ }^{8}$ As J.J. Johnson asserts, making his work acceptable for publication "dimmed the fire [of Aksenov's] pen" but also saved him from internal exile and confinement within the Soviet borders (36). That a writer has to (and does) sacrifice his aesthetic principles for the opportunity to see the world does not only indict the closed, claustrophobic Soviet society but also illuminates the link between the freedom of movement and creativity: Aksenov's spiritual and literary survival might not have been possible had he been banned from travel.

For Soviet intellectuals, trips to foreign countries satisfied a longing for freedom of movement and for the cosmopolitan Western culture that they felt connected to. Aksenov asserts that, although his generation "had been processed from childhood with a view to making it the first generation of ideal Soviet citizens, grateful for being allowed to live," their great dream was a romantic dream of escape, of crossing the frontier, of life abroad (RR 44). The ideal of Aksenov's and later generations was probably close to what Georgiou calls "free-floating individuals who move between social, geographical, and cultural spheres of [...] liberating cosmopolitanism" (49). Even when movement across borders was not possible, the cosmopolitan ideal could be approximated by consumption of Western literature and art. To a large extent, Cold-War-era intellectuals who were setting themselves in an opposition to Soviet ideology and contemplating 
emigration owed their cosmopolitanism to Stalinist claims to cultural domination and to the Soviet Union's status as "the fourth Rome." Clark contends that literature played a central role in the realization of these ambitions because "though grounded in the local or national, [literature] can transcend linguistic and geographic limitations through publishing and translation" (162). In the 1930s, as Clark notes, the literacy rate in the Soviet Union was high, many Soviets were "avid readers," and translations of European authors were undertaken on a massive scale (139). In an effort to legitimize its cultural importance, the Soviet Union aggressively "sought and publicized foreign intellectuals swearing allegiance to Moscow," especially French writers, such as Andrè Gide, Romain Rolland, Andrè Malraux, and others (140). Despite the ensuing confrontational relations with the West, the tradition of publishing literary translations survived in the Soviet Union and the idea of cosmopolitan connections with other cultures was internalized by Soviet intelligentsia, resulting in a vision exemplified in Aksenov's and Limonov's writing.

Cultural, rather than political, dimensions characterize Limonov pre-emigration notion of the West presented in his prose poem "My Nacional'nyj Geroj.” In this fantasy, Limonov, a Russian "people's poet" and national hero, and his wife, "a poet and a Russian national woman," arrive in France on the personal invitation of the French President. During a reception in their honor, they are presented with French passports as honorable citizens of France. Strolling around Paris, Limonov is recognized by passers-by and prominent cultural figures, such as Michelangelo Antonioni, a famous Italian director, who solicits Limonov's participation in his films. Limonov dines with Salvador Dali who later gladly illustrates Limonov's poems. After several American magazines (Readers' Digest, Atlantic, Newsweek, and the Rolling Stone) publish articles about Limonov, the Rolling Stone invites him to visit the Unites States "to get acquainted with the life of American youth." The author's self-aggrandizing aside, this air castle is based on beliefs common among Soviet intellectuals: continuity with and appropriation of Western culture as well as expectations to be 
acknowledged by the West as belonging to a common cosmopolitan culture that transcends political borders. This poem also ascribes to the West the reverential attitude towards poets peculiar to Russia and mirrors the Soviet government's constant efforts to court Western intellectuals. In some form, similar premises were shared by most of Soviet intelligentsia.

As the trajectory of Limonov's imaginary journey (Moscow-Paris-America) suggests, the center of cosmopolitan culture has moved from Europe across the Atlantic. Clark notes that for the Soviet intellectuals of the 1930s, Paris was

the mecca to which disaffected or exiled intellectuals from all over the world flocked, or where they sought to have their work published or recognized, a key to their elevation from the category of "national writer" to an international or cosmopolitan author with "world" recognition and sales. (141)

Until the mid-1930s, the Soviet Union aspired to similar status of the world's cultural hub, but undermined its own ambition by increasing isolationism and internal repression of non-conformist literature and art (141). Due to the post-World-War-II global shift in the balance of political powers and to the Soviet propaganda's constant focus on the United States, America displaced European capitals as the cultural center in the imagination of Soviet intellectuals. Instead of previously widely taught French and German, English became the prevalent foreign language required by the Soviet educational system. Tantalizing samples of American pop culture were infiltrating the Soviet Union, accentuating for Soviet intellectuals their insulation from the broader cultural scene. Brought up on the notion of "world" culture, they were attracted to what they imagined as its old (Paris) and new (America) hotbeds. It is the pull of this novel, technological-era cosmopolitan center that prompted Aksenov not to stay in Europe but to choose the United States as his place of residence.

Like most Soviet intellectuals, Aksenov had a notion of the West (and of America in particular) that was romanticized and politically naïve. John B. Dunlop argues that "[f]or Aksenov, 
the West is not primarily a system of political checks and balances—not democracy—but rather a colorful, variegated reality whose bright plumage and gaudy freedoms contrast starkly with the gaunt and self-restricted East." Dunlop asserts that Aksenov's West "is the West of Fellini” and, quoting one of Aksenov's novels, a "permanent, half-insane carnival” (121). Aksenov is the first to admit that his image of America was "impossibly idealized and distorted," but he claims that it was still true in essence (SMB 19). It reflected the shift away from Stalinist ideology and from the revolutionary fervor of Aksenov's predecessors, Soviet authors who visited the United States and published their accounts of the journeys. Since Gorky’s and Mayakovsky’s books were very influential in creating the Soviet image of America, Aksenov was compelled to engage in a discussion of and arguing against their anti-American positions. Although these books had always been considered staple anti-American texts, Aksenov reads them in the light of his own proAmerican convictions. He rightly observes that both authors viewed America through the prism of their Marxist ideology, with Mayakovsky being "torn between delight and hostility" towards America and Gorky being “irritated by the place." Because Gorky also labels jazz "the music of the fat" (that is, of the rich), Aksenov ascribes to him "total lack of aesthetic sensibility" (SMB 9-10). According to Aksenov, Gorky and Mayakovsky hated America because they "sensed deep down that [it] represented an alternative to violent revolution," but admitting it would have negated the value of the revolutionary cause to which these writers had dedicated their lives (SMB 11). By contrast, young people of Aksenov's generation rejected "the romance of the revolution" that resulted in "the monstrously bloody, monstrously dreary Stalinist way of life" (SMB 19) and opened their minds to outside cultural influences. Aksenov sees his youthful fascination with America as a sign of disintegration of the totalitarian Soviet system. He notes that the world revolution that seemed imminent to early twentieth-century Marxists has not happened and that American capitalism, instead of perishing in the turmoil of class struggle, has created opportunities for 
technological advancement and prosperity (SMB 12). For Aksenov, the whole world seems to be moving "to a truly new, as yet unknown and undefined age of liberalism" (SMB12), and he, somewhat naïvely, praises the "powerful America" that is leading the forces of "liberalism and benevolent inequality" (SMB 19) thus ignoring the role America played in the post-World-War-II world politics.

Aksenov's viewpoint demonstrates that, similarly to his cultural views, Aksenov's political opinions have been formed in opposition to official anti-American propaganda that portrays the United States as a "world gendarme," an imperialist country that relentlessly and forcefully pursues its interests in all corners of the globe. After leaving the Soviet Union, Aksenov travels through Europe and has a choice of settling down there but makes a deliberate decision to move on to the ultimate immigrant destination. Due to his conversations with intellectuals from different countries prior to his arrival in the United States, Aksenov is aware of America's contradictory image in the world. However, he is not ready to be disillusioned in his American Dream or to admit that other nations can have legitimate reasons for opposing U.S. interference in their affairs. Aksenov's European acquaintances freely express their hatred of America and wonder why anybody would "leave Russia for America, one hell for another" (SMB 4). In the memoir, Aksenov sets out to investigate and contest the anti-American sentiments widespread among left-leaning intellectuals. Finding these feelings "oddly hysterical [...] as if America were not a country but a woman who has hurt a man's pride by cheating on him" (SMB 7), ${ }^{9}$ Aksenov comes up with examples that reduce international encounters to incidents of personal offence or misunderstanding. Such is the case of the teenage Che Guevara who is enthralled with America and decides to come to the United States as a stow away on a plane, only to be beaten up, locked in the unbearably hot plane for days, and then sent back to Argentina (SMB 8). To maintain the idealized image of America he has cultivated for the most of his life, Aksenov dismisses Che Guevara's passionate hatred of American 
imperialism as the result of this personal insult. He also suspects that other anti-American revolutionaries, such as Sandinistas in Nicaragua, "may have just such a 'plane' in their background" (SMB 8). Aksenov might have switched sides in the Cold-War confrontation of superpowers, but he is not yet able to see past its dichotomy and to notice that both the Soviet Union and the United States compete for influence in the so-called Third World to the detriment or even ruin of less powerful countries. He still holds the notion of America as a political opposite of the Soviet Union but starts questioning some of his assumptions that had survived his previous encounter with the country of his dream.

In the memoir, Aksenov revisits his first book about America, "Kruglye Sutki Non-stop," that was written after his 1975 two-month stay in California. Aksenov notes that it "contain[s] almost no criticism of American life" (SMB 212). He also admits that the book's "positive message about America" (SMB 213) runs counter to Soviet literary and journalistic conventions of portraying the West and to "ignorance, prejudice, and mythmaking" (SMB 217) that characterize books about the United States written by loyal followers of the Party line. It also violates stylistic norms of socialist realism. D. Barton Johnson argues that in "Kruglye Sutki Non-Stop" Aksenov continues to develop his technique of blending observations and fantasy and "recreates the mythological America of his imagination," whose elements include "the Mafia; Las Vegas, the American Dream corrupted; the ghost town of Calico, the movie-inspired myth of the Wild West; and the Carmel Jazz Festival, the quintessential American music" $(184,186,189)$. The cinematic and literary origin of Aksenov's imaginary America results in what the author himself admits to be the "carnivallike, hedonistic character" of his travelogue. Moreover, it presents America as an ultimate destination, a kind of "last frontier" where the hope of humankind lies (SMB 212-213). In the memoir, Aksenov suggests a complex combination of causes for the uncritical view of the United States presented in "Kruglye Sutki Non-Stop." It might have resulted from the California climate or the author's need 
to "shed the stereotypes of years of anti-American propaganda and Socialist realism" (SMB 212). More likely, his change of attitude demonstrates the difference between an academic visitor who is “'blown away' by the mythology of the place" (SMB 50) and an immigrant, between stopping by and settling down. When Aksenov comes to America for good and becomes "almost American," he starts noticing not only "the bright windows of [his] new home" but also its "mildewed corners" (SMB 212). In Search of Melancholy Baby results from this new vision.

\section{AKSENOV'S ENCOUNTER WITH AMERICA}

In the account of his émigré life, Aksenov promises his readers to create a more direct and less biased picture of the United States than his previous book offered. He is addressing both the American audience and his Russian readers, pro-American intellectuals isolated from the object of their obsession, yet hungry for some fresh news about it. Commenting on Aksenov's American writing, Arnold McMillin notes that he provides "an ironic and thought-provoking view of the West" (60). More importantly, Aksenov's account of his first impressions starts to dissolve the sharp boundaries between the all-bad, grim Soviet Union and all-good, jazzy America.

Unlike most immigrants from the Soviet Union who had never been outside their home country, Aksenov is a practiced traveler and can compare American places not only to the ideal but also to the America he encountered during his first visit. The first cracks in the American ideal appear even before "the new émigré" (SMB 6), arrives in the United States. Starting with his transAtlantic flight, Aksenov notices that, by comparison with his 1975 trip, "nothing seemed quite up to snuff” (SMB 5). Instead of "top-notch food, sexy staff, [and] Oscar-quality film," he is treated to a pitiful movie and synthetic food, served by "tired and unsociable" flight attendants who were "very much like their Soviet, old-gray-mare counterparts" (SMB 5). The author is surprised by "the stench of hackwork" that meets him upon arrival (SMB 6), admitting that his impressions were disappointing by comparison to his previous visit when "[e]verything had seemed better [...], 
bigger, nicer; everything had seemed more sensible and less smelly: less sweat and less deodorant" (SMB 6). Smells and tastes are particularly significant in an immigrant's perception of the new country. Irritated by the ubiquitous smells of popcorn in the movie houses, "of peanut butter, catsups and tacos," Aksenov suggests that "homesickness might be more biochemical than psychological." Having crossed the ocean, immigrants find water, air, soil, and foliage of a different chemistry, "so that bread, milk, fruit, and vegetables are different too" (SMB 124). Aksenov attributes his initial disappointment to a variety of reasons-from the visible consequences of the mid-1970s oil embargo to "the misanthropic miasma" of his own mid-life crisis. He is even willing to dismiss the perceived deterioration of American standards as a figment of his imagination (SMB 6) rather than to admit that anything is wrong with his ideal. Although in the interview given in 1982 to Lauridsen and Dalgård Aksenov states that America is "no longer a miracle" to him (25), The Search for Melancholy Baby demonstrates that the shedding of the myth is only beginning. Still convinced that "the American way of life [is] an alternative to Soviet socialism" (SMB 213), Aksenov is not ready to question the U.S. government policies or the ideology of capitalism; instead, he offers a cultural critique of America.

Unlike most immigrants, Aksenov arrives in America with a reputation of a prominent writer and numerous connections in academic and publishing circles. This privileged position allows him to choose among several job offers and locations. What Aksenov is searching for is a place that would both embody his dream and feed his nostalgia. Looking at his new country through the eyes of a seasoned traveler, Aksenov is constantly comparing its cities not only to Moscow and Leningrad but also to other places he visited and, ultimately, to his "own ideal of a real city" - a cultural center of a European kind, aesthetically pleasing and saturated with history (SMB 28). His aesthetic criteria can be quite specific, and their fulfillment is "extremely important." For example, he values "at least a hint of the art nouveau period" in the architecture (SMB 28), which is not as 
common in America as it is in Russia. In the absence of layers of history so visible in European and Russian cities, America seems to be "an aesthetic wasteland, an all-purpose factory, a dollar mill" (SMB 28). The sights of houses "built for profit, for Mammon alone" as well as occasional clumsy attempts to adorn them bring the author to despair:

I never thought the sight of fire escapes running along a brick wall would plunge me into deep depression, but is there anything sadder than the block after block of run-down walkups stretching across Brooklyn, Manhattan, Queens, Philadelphia, Chicago? (SMB 2728)

Aksenov is surprised to learn that fire escapes as well as other unappealing features of cities_-"gaps between buildings plugged up with garbage pails, porches with potbellied columns, and row upon row of narrow windows"- are in fact elements of a distinct style, "American urban pop" (SMB 29). Unable to appreciate it, Aksenov experiences aesthetic alienation from his surroundings, but his status of an exiled celebrity gives him an opportunity to move on and keep searching for a more suitable place.

Although Aksenov is an immigrant, the relative security of his future as a writer and academic allows him to retain some of the visitor attitude — a leisurely pace of traveling and observing and his signature humorous attitude towards the American scene. When an invitation from the University of Southern California takes Aksenov west, his cross-country drive reminds him of his literary antecedents. Similarly to the characters of Nabokov's Lolita, Aksenov and his wife “quickly became motel connoisseurs" (SMB 45). Aksenov also recalls Ilf and Petrov's 1935 journey and confirms seeing what they describe in their travelogue: "thousands of miles of paved roads, gas stations with cold drink vending machines and attendants who wipe your windshields; roadside cafés; abundant accommodations for the night." Expanding his predecessors' "list of wonders," that is, "amenities [that] the Soviet Union still lacks," he adds a description of restrooms 
that offer "a disposable toilet-seat cover to protect the endangered ass!" (SMB 44). Having traveled far and wide in his home country, Aksenov is familiar not only with the relatively comfortable life of Moscow elite, but also with the everyday misery of ordinary people for whom not only a toiletseat cover but also a toilet might seem a luxury: ${ }^{10}$

The sensation it would make in the Soviet Union, where public facilities offer neither toilet paper nor toilet seat! My own association was the highway police rest stop (on the two-lane road to the Crimea), where truck drivers squat to their heart's content around a shit house boarded up during the last five-year plan. (SMB 44)

Side by side with this direct comparison between the United States and Russia, Aksenov describes an experience mediated by his pre-conception of America. In a small Texas town, he sees people whose faces seem to come "from the westerns that made [his] youth: there sat John Wayne, Gregory Peck, Gene Autry [...] dressed in the same hats, vests, and boots" as Hollywood cowboys (SMB 45). Aksenov's perception of people and places is filtered through the cinematic images that have accumulated in his memory. No wonder that the expanse of the country lying between the coasts appears to be no more than a setting to Aksenov's narrative and certainly not a place that he would consider for permanent residence. However, with a second look at the location of his previous visit, his dream world starts to disintegrate.

Finding himself in Los Angeles, where he stayed during his first sojourn in America, Aksenov is disappointed both aesthetically and culturally. He sees both the place and its life style in a new light and is finally able "to grasp the reality" behind the California-Hollywood myth. He is critical of the city where urban pop is "strongly entrenched [...and where] the ugly, dumpy, utilitarian structures extend for miles on end along commercial boulevards [...and] billboards take the place of architecture" (SMB 50). Moreover, L.A. streets "expire after dark" producing "the 
neutron bomb effect." Asserting that "empty streets attract attackers," Aksenov urges L.A. residents to break the vicious circle of fear:

Get out of the house! [...] Get into the streets and watch the muggers melt, the burglars bolt! Put some life back into the city! Don’t hide away in restaurants! Open outdoor cafés! The climate is made for it! (SMB 50)

Aksenov admits that L.A. might be "merely a radically different mode of urban existence" to which he is not yet attuned (SMB 50). Neither is he able to connect to the film world. From his Russian experience, Aksenov knows “movie people [to be] always live wires," but Hollywood parties strike him as "lugubrious, businesslike affairs [where] even Eros [is] out to lunch [and where] everybody's eyes seem glazed over with dollar signs" (SMB 50). Disillusioned in his previous idealized image of Southern California and determined to find a place of high culture that would also be pleasing to the eye, Aksenov returns to the East Coast. He decides to settle in Washington, D.C., rather than in New York, the most popular destination for Soviet immigrants.

In addition to practical considerations that guide most immigrants' choice of residence - in the rare cases when they do have a choice-Aksenov's comparison of the two cities is based on the possibilities for assimilation they offer and on their aesthetic value. As the largest enclave of Russian-language population in the United States, New York provides economic and cultural support to new arrivals and, due to its high concentration of publishing businesses and its vibrant cultural life, might seem an obvious choice for an immigrant writer. However, New York's populous Russian diaspora presents a challenge to Aksenov's purpose of studying American culture. He does not want to "be stuck in a Russian village," that is, to live in a place where he could forget he has left Moscow and where his foreign accent would not sound strange (SMB 24-7). Although Aksenov admits being fascinated with New York's “unbelievable physical presence, its splendor and misery and crime and punishment, its heartrendering love stories and wonder-working 
lip, its instant deaths, fortuitous encounters, political gambles, and endless quantities of food and drink" (SMB 26), the filthy and crime-ridden city of the early 1980s does not satisfy his aesthetic cravings. Washington wins the comparison in no small part because it turns out to be the only city in America that resembles both Moscow and Paris and where the sight of a single building (the east wing of the National Gallery, to be precise) can start "cosmopolitan juices flowing" (SMB 59). Moreover, still convinced that America is "freer of xenophobia than any other nation" and welcomes all refugees "washed up onto these shores" (SMB 37), Aksenov entertains the hope of blending in and chooses to live among Americans in Washington rather than among Russians in New York. However, all American cities, with their contrast between the posh and the poor, challenge Aksenov's ideal vision of the United States as a near classless and prosperous society.

Like other Soviet immigrants, Aksenov did not expect to see in America embodiments of the anti-American propaganda picture because the American Dream was based on a rejection of Communist propaganda. Thus, when the Soviet press illustrated the inequities of the capitalist system by juxtaposing extreme images of luxury and poverty, pro-American Soviet intellectuals dismissed the images as excesses of the ideological war. They went to the opposite extreme and became convinced that certain negative things_-homelessness, poverty, even deterioration of buildings — could not happen in America although they were common in other parts of the world. In reality, to new-comers' great disappointment, the image that emerged from closer inspection of American cityscapes was that of a country with numerous areas of blight and its own set of problems. As Aksenov finds out, a face-to-face encounter with South Bronx can easily dispel an immigrant's cherished myth of America "as an ideal society, prosperous and romantic" (SMB 31). Even in Manhattan, the contrast between the "fantastic" skyline and the pot-holed grimy streets brings to an immigrant's mind a comparison with "a snazzy broad who fusses over her hair but forgets to wipe her ass" (SMB 23). ${ }^{11}$ Similarly, Aksenov is shocked at seeing "hefty rats running 
around the capital of the United States of America," cockroaches infesting his apartment, and bums living in a back alley shack (SMB 75-76). Unable to dismiss "the South Bronx phenomenon" as a mere "phantom of Soviet propaganda" (SMB 30), Aksenov keeps defending his ideal, asserting that outside the big cities lies "the real America of neat little towns, well-stocked gas stations and supermarkets, spacious shopping centers, and white clapboard houses" (SMB 30). The main contrast for the author and his Russian readers is, of course, with the Soviet Union where all resources are funneled into military spending and to big cities, while "the countryside and villages are left to rot" (SMB 30). Aksenov is glossing over America's "notorious 'urban crisis"” (SMB 30) without delving into its social or racial aspects and without even attempting to explain why prosperous suburban America is more "real" than its dilapidated urban centers. Still, he chooses to live in a city rather than in the suburbs because the American Dream of late twentieth-century East European intellectuals is an urban dream and their ideal vision of America is that of a cosmopolitan city.

During Aksenov's first years in the United States and in spite of his initial disappointment in American cities, "the American taste for suburban life [is] still alien" to him. He starts apartment hunting in D.C., looking for "something that reminds [him] of [his] former life yet something [he] did not have_could not have had_-in that life" (SMB 73). A Wyoming Avenue apartment complex, with its view of the Capitol and the famous monuments, becomes the place that finally "evoked the vague vision of [Aksenov's] Muscovite dreams" (SMB 75). The inside of the apartment is even more impressive than the spectacular panorama outside. Although Aksenov's Moscow everyday existence was not as primitive as some Americans imagined (the manager showing Aksenov and his wife around the apartment complex assumes that these Russian immigrants have never seen an elevator), the apartment is equipped with appliances that the Soviets have only read about: "thermostats, a built-in washer and drier, a dishwasher, a microwave oven, a self-cleaning oven $[\ldots]$, an exhaust system, a sink disposal unit, and finally a compactor" (SMB 75). Aksenov 
revels in the abundance of technological toys and continues the list of American wonders with an inventory of his personal possessions that are worth reporting to his Russian readers:

Our white Wyoming cube is stuffed with [technology], piled high with cassettes, records, the upstairs tape recorder, radio, TV set, the downstairs tape recorder, radio, TV set, a VCR, a single lens reflex, a Polaroid, four typewriters (three electric, one electronic), a PC and printer, a copy machine, several calculators, a baby Benz under the living-room window and the old Omega out in the street, not to mention the Exercycle, shower massage, electric hair drier, electric shaver, electric blanket, electric hair curlers, electric coffee grinder, coffee maker, food processor, toaster, iron, vacuum cleaner...And that is only half of what surrounds us $[\ldots]$ every minute of the day. (SMB 75)

Not all items on this list are rarities in the Soviet Union (most households do have irons and vacuum cleaners), but no Soviet reader would take for granted two cars or the abundance of gadgets that can be used for disseminating information. In the Soviet Union, the selling of typewriters was tightly controlled by the government, copy machines were not available to individuals, and PCs were practically unheard of. Aksenov's impressive list proves both an increased material prosperity of his family and a more liberal atmosphere in which he now lives — both of which rebut the Soviet propaganda warnings about the poverty and the tight ideological control that await immigrants in America.

That a fresh immigrant can afford such excess of consumer goods also demonstrates that the lifestyle of "bourgeois decadence" (SMB 75) is not limited to the upper classes, and Aksenov uses this opportunity to counter the major Marxist claim about the impending end of capitalism. Ironically, Aksenov bases his analysis on the Marxist premise of purposeful linear development of history, stating: "[n]ow that capitalism has brought luxury to the millions, it has reached a certain plateau. If it intends to develop, it must branch out in other directions - work to improve mass taste, 
for instance" (SMB 75). This personification of economic and political forces is reminiscent of Communist Party documents that proclaim lofty goals of socialist development, such as bringing prosperity to the masses or cultivating Soviet citizens into well-rounded individuals. By attributing intentionality to capitalism, Aksenov seems to imply that this economic system possesses some central intelligence that channels and regulates the unceasing drive towards expansion and technological innovation the way the State Planning Committee of the Soviet Union sets plans for industry, agriculture, and education.

Aksenov's constant comparing of America to the Soviet Union is rife with other paradoxes. He realizes the irony of his reasons for renting an apartment in a D.C. high rise- because it reminds him of "certain soulless sections of Moscow" and because he feels "nostalgia for a purely functional living space" (SMB 56). However, ironic twists of his logic are not always obvious to the author. For example, in his outrage at the piling back-alley trash and rat infestation near his apartment, Aksenov would see authorities interfere and take charge, as they do back in the Soviet Union (SMB 76). When he faces inefficient and indifferent service clerks or delivery people, Aksenov wishes that he were able to get what he needs by bribing them (SMB 77-79). Aksenov voices nostalgia for the corrupt service relations of the Soviet society where salespersons, plumbers, and tailors will do their job promptly only if you "grease [their] palm[s]" (SMB 77) and even for the close government control of everyday life. Still upholding a slightly dented ideal of America, Aksenov is starting to idealize some unsavory aspects of Soviet life.

Aksenov's dealings with American bureaucracy in the process of documentation and naturalization challenge his image of the United States as the opposite of the Soviet Union. To his surprise, the bureaucratic ambages he encounters in America are similar to the ones that had burdened his life back in the Soviet Union. Aksenov's interaction with the system is typical: numerous visits to the local INS office involve hours of waiting "in a line of our brothers-in-exile." 
Each new meeting with the INS officials brings a requirement of more papers to be submitted, and if applicants move from one state to another, their files are lost (SMB 86-87). Aksenov notes that government agencies in America operate in the same slowly grinding way as their Soviet counterparts. Moreover, the behavior of their officers can be very similar. All Soviet bureaucrats are rude to petitioners almost at all times, but American officials are not always "on their best [that is, computer-like] behavior" either (SMB 88). Aksenov has an unfortunate chance to be the object of an angry outburst when, in response to his explanations about another form that he is supposed to have filed but hasn't, the INS officer "roar[s], 'Not another word, do you hear? You have no rights in this country! You are a refugee! The United States government did not ask you to live here!"' (SMB 88). This unexpected display of emotion from an official compels Aksenov to look at the human side of the interaction and ponder the reasons for a black female officer to be angry with a white male immigrant. Although Aksenov mistrusts Soviet propaganda, he is still influenced by its simplistic portrayal of race relations in America. When a more experienced immigrant, a Polish friend of the author, bluntly declares that "accent or no accent, you're white and your wife is blond; ergo, you belong to a dominant race" (SMB 90), Aksenov makes an honest attempt to understand interracial relations in America. He starts with examining the nature of what he calls "a racism of positive feeling" that is wide-spread in the Soviet Union: "[a] black cannot be evil or clever or perfidious; a black can be only oppressed" (SMB 95). This hypocritical internationalism of Soviet ideology does not compare well to America that "simply lets in crowds of exotic foreigners" (SMB 96). Aksenov's naïve account of the U.S. immigration policy demonstrates that he is unaware of his own privileged position among his fellow-immigrants who come from non-white countries or speak English poorly. In fact, Aksenov hardly touches the question of language acquisition that is central to Hoffman's autobiography. 
Nevertheless, Aksenov makes a note of the ethnic variety of American cities — something that strikes him as different from his previous visit. Aksenov supposes that the country might have changed or that other ethnic groups are "easier to notice after you yourself turn into an ethnic minority" (SMB 25). With a note of pride, Aksenov describes Fifth-Avenue stream of pedestrians as peaceful, shoulder-to-shoulder ranks of a Filipino, a Hindu and an Eskimo and a Moor and an Aztec and a Greek and a Phoenician and a Persian and a Pecheneg and a Roman and a Carthaginian, and, as the poet says, 'a proud son of the Slavs and now a Finn and then a wild Tungus and a Kalmyk, the steppes' true friend.' (SMB 95) ${ }^{12}$

The quote from Pushkin underscores the literary, even mythological nature of these images (there are, after all, no Phoenicians or Carthaginians in the modern world). The author's tongue-in-cheek intentions become clear when in the next sentence he declares that he wouldn't be surprised " to find a few assorted Amazons, centaurs, or denizens of Atlantis..." in that crowd (SMB 95). For Aksenov, America is anything but ordinary. It is still a fantastic and phantasmagoric place, the source of the unexpected and the exotic. It is also a home to hundreds of thousands of people who originate from the same country that has just cast Aksenov out of its sacred domain.

Although Aksenov has put a distance between himself and the most numerous immigrant enclaves in New York, he naturally gravitates to the hubs of Russian culture in all cities he visits. In portraying Russian immigrant community, Aksenov is striving to show the complexity of the scene but falls into the trap of idealization - this time of the old immigration. On the one hand, Aksenov notes that the old émigrés who escaped during the 1917 Revolution do not match the Soviet propaganda clichés of "a cynical White guard villain, a traitor, [...or] a derelict weeping into his rotgut over Mother Russia and her birch trees." Nor do they resemble the image created by Soviet dissident intellectuals - that of "Vladimir Nabokov—writer, aesthete, lepidopterist extraordinary" (SMB 173). Acknowledging that "old-time American Russians [...are] perfectly normal men and 
women," Aksenov declares their faces to be "untouched by the decades of Soviet deformation," to be "genuinely Russian" (SMB 172-173) — presumably unlike his own and those of other new arrivals. Such idealization of pre-revolutionary Russia is common among Soviet (and now postSoviet) intellectuals who feel cut off from their historical and cultural roots by the same brutal force that displaced the old emigration.

Somewhat unrealistically, Aksenov reports peaceful coexistence of different waves of immigration and of various ethnic groups that originate from the Soviet Union. He identifies Russian Orthodox Church as "the main unifying force" for old and new immigrants (SMB 172), for ethnic Russians and for Jews, who also "head for Russian churches at Eastertime to have their kulichi, their Easter cakes, blessed" (SMB 177). This account is contradicted in the data quoted by Orleck: surveys show that "a large majority [of new immigrants from the Soviet Union] strongly identify as Jews, far more strongly than American-born Jews" (100). Orleck also notes that in the 1970s-80s “[b]attles between old and new East European immigrant cultures strained Jewish life in New York" (86). Moreover, relations between different ethnic groups arriving from the Soviet Union were not always amicable either. For example, Russian and Ukrainian Jews insist that Bucharan Jews who come from Central Asia "are not 'real Russians."” Public school teachers report tensions resulting from hostility among immigrant communities (123). Thus, Aksenov's idyllic picture seems unwarranted, as does his surprised reaction to encountering in the United States such "less attractive aspect of Russia" as anti-Semitism, which he immediately dismisses as insignificant and even dying out (SMB 173-174). Considering that this phenomenon has been pervasive both in pre-revolutionary and in Soviet Russia, the author's prognosis of its impending demise among Soviet diaspora seems overly optimistic.

Still, common tastes — whether in food or in art — do bring immigrants together, so it is not surprising that Russian life in big cities revolves around specific locations. In New York, they are 
"the offices of the two main Russian-language newspapers, the Edward Nakhamkin Gallery, the cultural center in SoHo, the Russian Café on Madison Avenue, and the Kavkasian Restaurant on Second" (SMB 25). Aksenov emphasizes the importance of Russian restaurants that provide traditional ethnic staples and delicatessen, from "pot cheese-like tvorog" to Turkish delight (SMB 178). He also describes “"a reverse phenomenon' [...] of cultural nostalgia” that characterizes new immigration. People who "chased after American films" when they lived in the Soviet Union now “chase after Soviet ones" (SMB 177). They also attend performances of famous Soviet actors and poets whose connection to the Communist regime can be disregarded because of their "purely Russian” appeal (SMB 178). These nostalgic cravings have roots not only in the immigrants' past but also in their disappointment in American cultural scene.

Still connected to the previous center of their existence, most immigrants are dissatisfied when they see only a partial overlap of their own cultural priorities and those of their new country. They have exaggerated expectations of an America that is supposed to provide all the opportunities absent in their former country and to recognize the primacy of their native culture. In spite of its central role in world politics, America strikes Aksenov as provincial and unconcerned about world affairs. Back in the Soviet Union, when Aksenov and other America lovers imagined life in the United States, they never thought that it could be boring. After all, "How can one be bored in a city with a frontier name like Indianapolis or a state whose name exudes adventure like Minnesota?" (SMB 32). ${ }^{13}$ To his surprise, Aksenov finds little excitement even in the U.S. capital. Contrary to immigrant expectations, important international events do not get as much attention in American media as local stories of fires, crime, or allegations of sexual abuse (SMB 32). Taking the example of sports, Aksenov is amazed to find out that Soviet media coverage of international sporting events, which he had always considered inadequate, is actually more extensive than what he could find in American TV programs or newspapers. While the domestic baseball competition is named 
World Series, widely broadcasted, and commented on, an international hockey tournament in Canada "is passed over [...] in silence" (SMB 121-3). To Aksenov's mind, instead of producing "a hothouse of cosmopolitanism" (SMB 124), America is populated by people who are "detached, withdrawn, sequestered in their American planet" (SMB 122) - in contrast to the keen interest he and his Moscow friends always took in the world beyond the Soviet borders.

Attempting to explain these differences between the two countries, Aksenov gets close to understanding the myth of American exceptionalism. He speculates that

[i]n a closed society like the Soviet Union, public interest (and not only in sports) is directed outward, while in open, democratic America it is almost wholly inner directed. The outside world interests Americans much less, either because they assume, a priori, that it is worse than their American world or because that American world is simply too overpowering. $(S M B 123)$

Aksenov's own convictions and decisions validate this observation. If America is the ideal land of freedom and the ultimate destination — which it has been in the dreams of countless immigrants, including Aksenov - then the American world is a priori better than any other. Starting with such canonical American texts as Crevecoeur's Letters, to quote Behdad, the outside world and Europe in particular, "represents America's past, the past that must be abandoned or negated in order for the America of the future to emerge" (36). Consequently, any interest in the outside world can be equated to looking back to inferior political systems or cultural phenomena. Aksenov's account of his first years in America both reenacts this exceptionalist paradigm and critiques its manifestations.

Aksenov's speculations about relationships among different countries and cultures demonstrate a complex and ambivalent position. Sometimes he does not notice the limitations of his viewpoint, namely that by outside world he mostly means Europe. Thus, he concludes his reasoning about the American world with a statement that "[d]espite the iron curtain the Soviet Union is in 
many ways closer to Europe than Europe's closest political and economic partner, America" (SMB 124). Many Soviet citizens do cast their curious gazes outward - to the West — and by the author's admission, think, for example, of the Chinese "as beings from outer space" (SMB 15). Ironically, only a few years after the publication of In Search of Melancholy Baby, Aksenov states in an interview that it is America that has given him a new understanding of cosmopolitanism, by which he apparently means an ability to see numerous ethnic groups as human beings and "inalienable member[s] of society" rather than abstractions:

When I was living in Moscow, what did a Chinaman mean to me? Some slant-eyed person whom you don't understand, and all you feel is alienation. [...In America m]y seminar invariably includes a Chinaman, a Korean, a Vietnamese, a Pole. Although I am Orthodox, I like going to the Catholic cathedral where Poles, Czechs, Filipinos and Irish are all sitting together. There's a moment when they all turn towards each other and shake hands. And it's great when you are united in that handshake. Suddenly a human molecule is formed. And I value it greatly. (qtd. in Graffy 130-131)

In spite of its much-heralded internationalism, Soviet system was unable (and unwilling) to foster such human connections. Only in America did Aksenov acquire "a sense of belonging to humanity" and learn not to stereotype other ethnic groups, for example black Americans. As he acknowledges in another interview, "This sense of America as an ethnos has widened my ideas, widened my world" (qtd. in Graffy 131). However, the fresh observations recorded in the memoir are significant because they mark the author's departure from his idea of America as the cultural center of the world. After Aksenov takes a close look at American literary scene, his belief in America as a place of creative freedom also becomes undermined. 


\section{CREATIVE FREEDOM IN AMERICA}

Coming from "the empire of Socialist realism," Aksenov assumed that American cultural scene would be "a glittering, pulsating cosmopolitan playground." Instead, he is perplexed and disappointed to see a virtual "clampdown on the avant-garde," especially in the fields that have the largest audience-TV and movies (SMB 145). Theater seems to be the only cultural sphere that encourages talent and innovation rather than "wooden mediocrity," but it is considered of secondary importance in America and has to "take a back seat, to accept the role of a low-income relative" in the shadow of TV and Hollywood productions (SMB 143). Even in the absence of overt censorship, directors working for mass audiences learn to avoid complexity or any techniques and styles that might be deemed, for example, impressionistic. As a result, the aesthetic standards of American television are so low that viewers easily "mistake an Estée Lauder commercial for the next scene" (SMB 144). Aksenov realizes that directors have little choice "when even Academy Awards are handed out on the basis of box-office receipts" (SMB 144). He compares American cultural production to a general store, naming such commonalities as "preference for the hot item, fear of risk, sheer panic at the thought of innovation" (SMB 145). This general commercialization of culture affects his own field — literature — and limits the writer's freedom that Aksenov imagined as practically unbounded.

For a Soviet author who had to live and work under the watchful eye of the Communist Party and its secret police, America appeared to be the opposite of the claustrophobic Soviet society and an ideal of independence in all aspects of life: movement, thinking, speech, and aesthetic choices. In his 1992 article "Residents and Refugees," Aksenov describes the absence of creative freedom in the Soviet Union in spatial terms, noting that "[i]n an area covering eleven time-zones the regime contrived to create an unimaginable crush of people, a heap of pitiful belongings, a labyrinth of Kafkaesque corridors and dead-ends" (RR 42). On one level, Aksenov is describing such crowded physical places as communal apartments that house the majority of big-city residents 
and the official haunts of Moscow literary nomenklatura —established Soviet writers who congregate in the writers' restaurant, live in the exclusive housing projects, and spend summers in the writers' village of Peredelkino (RR 42). On another level, Aksenov is talking about the stifling coziness of conformism that comes with official recognition. A writer who is "considered to have become part of the 'national heritage'-Lenin's definition of your personal talent [...becomes] protected from excessively open expanses, where agoraphobia can turn you into a worthless reed and no intoxicating ecstasy in freedom will provide recompense for what you have lost" (RR 43). The "protection" is a set of privileges that frees writers from the everyday strife and stress experienced by ordinary Soviet citizens; it is also a set of restrictions on the ways authors choose and approach the subject of their writing. To his surprise, Aksenov finds numerous similarities between the Soviet and American literary scenes.

In America, the freedom of creative expression is not limitless or absolute as Soviet writers imagined, but constrained by economic factors. Aksenov discovers that it is the pressure of the market that compels writers to avoid risks and give the mass audience what it wants. As a result, their "literary hackwork" reminds Aksenov of the "ideological hackwork" of some Soviet authors who write according to the Party directives. Moreover, America's obsession with best-sellers makes the guild of best-selling authors similar to the Soviet party nomenklatura, which "may be hard to join, but $[\ldots]$ is nearly impossible to leave.” Because making it to the best-seller list often ensures success of the author's subsequent books, ambitious American writers study—and follow— the demands of the marketplace (SMB 155). Similarly to high-ranking Soviet writers who have to maintain their image of loyal Communists, American authors "are concerned with creating and perpetrating a public image" that would meet the expectations of their readers (SMB 152) and the courage to write what is on one's mind might be as rare in the United States as it is in the Soviet Union. When Aksenov realizes that "the hunt for high returns produces both bad taste and 
stereotyped writers" (SMB 155), his romantic ideal of creative life in America is shaken and he turns an admiring gaze to the place that he has left behind. Now he attributes "the aura of hazardous undertaking $[\ldots]$ to the oppositional literatures of Eastern Europe and the Soviet Union” as well as to literary exile (SMB 152). In judging literature as in judging politics, Aksenov seems to be reversing the values of the Soviet-American dichotomy; however, his insider's understanding of both literary worlds allows him to present a more nuanced picture of this field.

Aksenov maintains that commercial considerations do not "deprive the writer of the right to use his claws" (SMB 156), that is, to write according to his beliefs and aesthetic leanings. Neither are the demands of the market or of any interest groups equivalent to the control of literature exercised by the Soviet government. In a typical incident, an American counterpart tells Aksenov that a local school board in Missouri "ordered [his] books off the library shelves [...because of his use] of some four-letter words and [...his] characters' shenanigans." The American announces a return to the McCarthy era and only after a while realizes that complaining about censorship to a writer who was exiled from his country for his books it tactless (SMB 154). In spite of some similarities between the two systems, the differences are glaring. In addition, although Aksenov declares that in America "the line between serious and popular literature has virtually disappeared" (SMB 155), he sees enough public interest in literary classics in which "the Yoknapatawpha mule still flicks his tail, Spanish bridges still explode in the air, the beat generation plays it cool in jazz and life, and the wounded centaur of New England hobbles along his way" (SMB 156). Gradually, Aksenov learns that non-commercial creativity dwells quietly and unobtrusively in the centers of intellectual life: research institutes, university campuses, and small publishing houses. In exile, Aksenov has to turn to the same handful of like-minded intellectuals who used to be his lifeline in Moscow, and he acknowledges that it is the interest of American literary scholars that saved the free Russian literature from extinction. 
Aksenov pays tribute to Carl and Ellendea Proffer, the founders of Ardis Publishers of Ann Arbor, Michigan, who have made Russian literature their cause. For more than a decade, they traveled to Moscow and Leningrad to seek out and publish books that had no chance of seeing the light of day in the Soviet Union. Choosing texts for their artistic merits rather than potential profitability, the Proffers saved many young underground writers from oblivion. Moreover, books produced in the basement of their suburban house, through a network of messengers, found their way back to the Soviet Union and quenched at least some of the thirst for authentic, non-ideological literature (SMB 159-170). Besides publishing and circulating books, the Proffers helped several Russian writers who ended up in the United States. Benjamin Stolz and Michael Makin call Carl Proffer "a critical link" that in 1972 helped secure a teaching position for Joseph Brodsky who had just been deported from the USSR. Although Brodsky had dropped out of high school at the age of 15 and never attended college, he was hired by the University of Michigan Department of Slavic Languages and Literatures and later "promoted to a tenured professorship [...] without being nominated" (Stolz and Makin). Having an international reputation of a persecuted Soviet writer helped Brodsky — as well as Aksenov— to secure a job and to get his books published.

Aksenov starts his professional career in America as a writer-in-residence at the USCA and then accepts fellowship in a prestigious Kennan Institute of Advanced Russian Studies at the Wilson Center of the Smithsonian Institute. The opportunity to have an office in the main tower of the iconic Smithsonian Castle seems to Aksenov analogous to “an invitation to work in Stalin's old Spassky Tower Kremlin office" (SMB 60). Even more astonishing is the generosity of the American academic community that approves "an amazingly broad range of topics" for the fellowship research, including, in the author's case, writing a novel (SMB 60). ${ }^{14}$ After an "enjoyable and fruitful" year at the Kennan Institute (SMB 61), Aksenov goes back to teaching. The Goucher College campus becomes for Aksenov what Cornell University was for Vladimir Nabokov: a safe 
haven "from all the executions, revolutions, prisons, and escapes" (SMB 187). It is also a place that is unimaginable in the Soviet Union — a unit that is territorially and administratively autonomous from "the colossus of the state" (SMB 182). As in the description of his D.C. apartment, Aksenov proudly offers an inventory of available facilities: "340 acres of woods, fields, and parking lots, to say nothing of lecture halls, an observatory, an ecumenical chapel [... ], a gymnasium and pool, playing fields for field hockey and lacrosse, six tennis courts, and a stable and show ring" (SMB 184). This is not an advertisement brochure for potential students but a report to other Stateniks back home that confirms the American ideal: America has everything we dreamed about and more; although there are some glitches in the system, it works wonderfully; there are places in America where one can feel at home.

In the end, the campus becomes Aksenov's dream place that is more than "simply a retreat or the source of a monthly paycheck" (SMB 188). Although the subject he teaches is "light-years away" from the background and concerns of young Americans, Aksenov manages to create a vivid picture of Russian writers' struggle for human dignity and then watches the snobbish ignorance of his students turn into a "budding sophistication" (SMB 182, 187-191). University campus is a place where Aksenov can make Russia more real for his American students, counteracting the distorted image of Russia created by decades of the American Cold-War propaganda. It is also a place where he can write freely about America for his Russian audience. Finally, it is a place that allows Aksenov to establish connectedness to his new country. In a later interview, Aksenov acknowledges his positive relations with America, saying:

I treat this country as home, not as my motherland [Rodina], you'll understand that, but as home. They gave me refuge here, not a feeling of peace but a feeling of home. I don't feel out of place here, because there are millions like me, various refugees from the entire world. (qtd. in Graffy 130) 
This statement seems to be a fitting conclusion to the analysis that was started in Aksenov's memoir. It acknowledges both the contrast between the two countries (the United States as a refuge from the oppressive Soviet system) and the author's sense of unity with the people who inhabit his new place.

Aksenov's acceptance of and attachment to America result in no small part from his ability to tone down his expectations, and to learn a new profession-teaching. Academia has proved to be the saving grace of many dislocated intellectuals, such as Vladimir Nabokov, Joseph Brodsky, Edward Said, Czesław Miłosz, and Josef Škvorecký, to name a few. Even with its modest monetary compensation, teaching can ensure writers' spiritual and aesthetic survival, providing them with time to write, a connection to the publishing world, and a safe forum for expressing their ideas. Moreover, Aksenov was able to find his place in America due to the publishing industry's immediate recognition of his achievements as a writer. By contrast, to every story of literary success in America there are scores, maybe hundreds of untold stories of Russian intellectuals to whom fame and fortune were not as benevolent and who, like Limonov's protagonist, never felt at home in their new country. ${ }^{15}$

\section{LIMONOV'S IMMIGRANT RAGE ${ }^{16}$}

Limonov's portrayal of immigrant experience is the opposite of what McMillin praises in Aksenov's "unhysterical" writing. Instead of offering "a lively, revealing and, above all, balanced picture of his new homeland" as does Aksenov (McMillen 60), Limonov's protagonist condemns the capitalist system as cruel, unjust, and evil. Unlike Russia where a poet "has always been something of a spiritual leader," in America "a poet is shit" (Eddie 20) and is doomed to obscurity and poverty. Moreover, the greatly praised freedom of the so-called free world has its limitations: immigrants who write critically about the West have little chance to publish their articles just as back in the Soviet Union they were unable to criticize the Soviet system (69). Eddie's 
disillusionment and frustration result in tenuous connections to his American places, both engaged and unrooted.

Eddie comes to America with expectations similar to those of Aksenov, but he does not become a published author and has to live on welfare. Eddie grew up in Kharkov, "a provincial industrial center with the most numerous proletariat in the Ukraine" (47) where he was a petty thief "from the age of sixteen to twenty-one." That's when he "became a poet and an intellectual" and moved to Moscow (165). In the USSR, Eddie was an unpublished avant-garde poet who had to type and distribute his poems himself — eight thousand collections of them. He was celebrated as a samizdat author by Russian people who read his poems, "knew them, recited them by heart" (20). When Eddie emigrates from the Soviet Union, it is "in search of artistic freedom, that is, the opportunity to publish [his] works here," but he soon finds out that his works are "unneeded here, needed only there, in Russia" (145). Because getting recognition for his talent was the main reason for his emigration, Eddie does not elaborate on any other aspects of his American Dream. Since no publishing deals or comfortable jobs are waiting for Eddie in America, he makes a meager living of $\$ 150$ a month by writing for “a sleazy émigré rag” (88) and soon comes to a conclusion that “[w]hat's needed here is serious dishwashers, people who will do the dirty work without any literary reflections. Literature here has its own mafia, art has its own mafia, any business has its own mafia" (18-19). In fact, Eddie equates the American and the Soviet systems, neither of which provides opportunity for the so-called "creative intelligentsia' [...] artists, writers, filmmakers, and sculptors" (148) to live by their talents:

Ideology there, business here. That is roughly true. But what difference does it make to me exactly why the world doesn't want to give me what is mine by right of my birth and talent? The world calmly gives it - a place, I mean, a place in life, recognition — to the businessman here, to the party worker over there. But it has no place for me. (150) 
Without outlets for their creativity, immigrant poets and artists survive on menial jobs, "[t]he cheapest food, not always enough of it; dirty little rooms, wretched poor clothes, cold, vodka, nerves" (19)—a far cry from the dream America they imagined.

Eddie becomes even more embittered when his beloved wife, tired of waiting for their American Dream to materialize, leaves him for a prosperous American lover. Eddie not only abandons any attempts to pull himself out of poverty but also takes a cynical attitude towards the system that has, in his opinion, let him down:

I am on welfare. I live at your expense, you pay taxes and I don't do a fucking thing. [...] I consider myself to be the scum and dregs of society, I have no shame or conscience, therefore my conscience doesn't bother me and I don't plan to look for work, I want to receive your money to the end of my days. (4)

Eddie is flaunting his dependency on government support, thus undermining the myth of a proud industrious immigrant who gradually works his way up from the bottom of society. Paradoxically, in spite of his disillusionment in the dream of creative freedom, Eddie becomes enchanted with New York, "this great and terrible city" (19). The book is an account of Eddie's misfortunes and disappointments on the one hand and a paean to New York on the other.

Similarly to Aksenov, Limonov's protagonist revels in the sight of Manhattan, "the vast Great City, a Babylon" (79), and notes the discrepant beauty of "gilded Broadway reeking of urine" with its "solid wall of strolling people" (71). Eddie traverses the city on foot ceaselessly and tirelessly, sometimes covering as many as "three hundred blocks in one day" (213). As "a beggar in an alien land" (185), Eddie is intimately acquainted with the places that Aksenov sees only from inside a car if at all, such as deserted buildings, boarded up churches, or liquor stores that stay open all night (214-217). Observing the semi-ruins of poor uptown blocks - their "broken windows, fireblackened walls, all sorts of mold and vermin creeping right out to the street," Eddie thinks that 
"New York is rotting around the edges" and prophesies the spread of "already boundless sea of uninhabitable and semihabitable neighborhoods, terrible in their state of near war-time destruction" (140). ${ }^{17}$ While Aksenov is squeamish about cockroaches and indignant at the proximity of homeless people, Limonov roams the rough neighborhoods fearing "no one and nothing at all in this world" (74) and welcoming the danger of accidental sexual encounters-because he doesn't "have a fucking thing to lose" and is even "seeking death" (160). Seen from the lowest rung, the racial divisions of American society are fascinating rather than puzzling to Eddie because the street life of black communities reminds him of his "own provincial Kharkov, [his] hoodlum friends, [their] flashy dolled-up girls." There, he was in his right place: "Everyone knew Ed. They knew what he could do" (160). The black youths on Forty-second street between Broadway and Eighth would not accept Eddie into their game, so he "would have given the world, at that moment, to have black skin and stand among them as one of their own" (160). This longing for acceptance permeates Eddie's monologue.

Eddie wants some recognition from his new country and its people-if not for his poetry, then at least for his familiarity with its preeminent urban center. He declares:

I am a man of the street. I have to my credit very few people-friends and many friendstreets. They, the streets, see me at all hours of the day and night; I often sit on them, press my buns to their sidewalks, cast my shadow on their walls, prop my elbow or my back against their lampposts. I think they love me because I love them and pay attention to them like nobody else in New York. As a matter of fact, Manhattan ought to put up a monument to me, a memorial plaque with the following inscription: 'To Edward Limonov, New York's number one pedestrian, with love from Manhattan!' (213)

On a less grandiose scale, Eddie is vying for some warm human relationship and love. Although still heart-broken and pining for his unfaithful wife, Eddie starts dating Sonya, a Jewish immigrant 
from Ukraine, who lives in an apartment "that [does] not even remotely resemble an American one." Rather, it is a setting that is common in Odessa, with a "typical south Ukrainian dinner [...of] fried chicken, cucumber and tomato salad, bouillon" being served (116). Instead of awakening nostalgia for his youth, Sonya's apartment reminds Eddie of "the huge distance that separated Moscow from the Russian provinces" and of the gap between his intellectual aspirations, his “typical bohemian" life style (132), and the "philistine" existence of Soviet immigrants (117-118). The end of this brief loveless relationship confirms Eddie's determination to "languish" without people rather then turn to the repellent former compatriots whom he despises for having accepted “this world order" (86). Neither does he have a high opinion of Americans.

During his wanderings through the city and his eternal "search for love" (176), Eddie comes into contact with many Americans, but he automatically chooses his friends not among those who accept the hated system but among fellow-bohemians as well as "among the protesters and dissatisfied, among the insurgents, partisans, rebels, the Reds and the gays, the Arabs and Communists, the blacks and the Puerto Ricans" (92). Eddie's "enormous curiosity about life" takes him to such events as anarchist meetings, poetry readings, shows in NoHo and SoHo galleries, and theatrical performances in the Village. He boasts of learning the nuances of New York life "much more rapidly than [he] learned English" (85). Occasionally, these locations become enriched with meaning due to a brief but intense human connection. Thus, for a meteoric moment, shopping with Roseanne, his first American girlfriend, gives him a sense of belonging to a place: Suddenly I felt good about this neighborhood, about Broadway streaming past flooded in sunlight $[\ldots]$ about the microcosm of salesmen and customers who had known each other for years, for decades. I envied her a bit, Roseanne. [...] And I was inwardly grateful to her for having brought me into this world as if I belonged here, walking with her, Roseanne. 
Although I had passed on this very spot on Broadway time and again, it had never seemed to me so congenial, as if I belonged, because today I was not a passerby. (174)

Such moments do not last, so most of the time Eddie exists in "utter loneliness" (188), feeling alienated from everybody and every place. In spite of his intimate knowledge of the city, Eddie remains unrooted and unattached to it, even imagining his future elsewhere:

I'll go somewhere, to the Palestinians, if they survive, or to Colonel Qaddafi in Libya, or someplace else - to lay down Eddie-baby's life for a people, for a nation. I am a man who is ready for anything, you know. I will try to give them some gift. My heroic deed. My senseless death. (264)

Eddie is indeed ready for anything except an ordinary life. If he cannot be a poet, a prophet, or a spiritual leader, he does not want a safe niche in academia or any other kind of concession to the system.

Eddie is unwilling to follow the typical immigrant path because of his own kind of pridehe is not an average immigrant but an extraordinary talented person, a poet, and he refuses to submit to convention. Although he understands that "poetry-writing isn't a profession here" (27), Eddie is outraged when "cold-blooded Americans" advise him "to switch professions." He exclaims, "I could have conformed in the USSR, why the fuck come here to do it? That was all the Soviet regime wanted of me, to change my profession" (148). For Eddie, changing professions is the equivalent of conforming because it implies hiding "all [his] thoughts, feelings, ten years of living, books of poetry." It is impossible to "hide refined little Eddie [...and] lock him up in a shell of busboy" and to live a life of an ordinary man (149). Surprisingly, even jobs that are considered appropriate for writers, such as college teaching, also seem too much of a compromise to Eddie. When Bennington College offers him a position_- "something trivial, but connected with the Russian language" (39) — he rejects it as indignantly as he refuses to continue as a busboy: 
Shit if I'd go to your fucking Arlington or Bennington or whatever it is, to teach your zhlobby children Russian literature. ${ }^{18}$ I did not refuse to be bought in the USSR merely in order to sell myself cheap here. And please note-membership in the Soviet Writers' Union is a much better honor than a professorship, even at a university of yours (129).

A secure job in small-town America does not attract Eddie the bohemian. He realizes that "no Bennington or its American girls from good families could save [him], [he] would flee from Bennington to New York inside of a week" (39). Eddie's all-or-nothing demands exclude any concessions to bourgeois respectability or middle-class drudgery. He would rather remain a nobody in the squalor and excitement, the unpredictability and dangers of the big city that he both loves and hates and in which he will never feel at home.

Many Soviet writers of the Cold-War era came to believe the opposite of what Communist propaganda tried to inculcate in them - they began to idealize the United States as a place of creative freedom, of endless opportunity for expression, and of vibrant cosmopolitan culture. Because after 1968 the Party control of literature and art tightened, many intellectuals and people of creative professions saw no hope in staying in their country. Some of them were forcefully deported; others were pushed towards emigration by persecution or by lack of outlets for their talents. On their arrival in the United States, a few immigrants - mostly internationally known authors - were welcomed, guided, and taken care of, while the majority of immigrant writers and artists struggled on their own and received no recognition. Authors' ability to reconcile their expectations and their impressions of America ranged accordingly.

Aksenov becomes one of the few immigrant writers who adjusts well to his life in America and, by his own admission, is "sucked into the great big colorful world of American provincialism" (SMB 127). Aksenov's book is an attempt to conciliate the author's long-standing image of America 
with the actual place he encounters as an immigrant. It describes the author's transition from the life in the oppressive bleak Soviet Union to exile in what he expected to be a jazzy bright America. Aksenov gradually changes his uncritical and enthusiastic views of America, balancing them with a new, less romantic and more nuanced vision and dissolving the sharp Cold-War contrast between his old and his new country. Aksenov's American Dream, in fact American obsession, sustained Aksenov during his life in the Soviet Union and determines his perception of American places. Driven out of the Soviet Union by the Party's deadening control of literature and arts rather than by discrimination or poverty, Aksenov imagines America, first and foremost, as a place of intellectual freedom. He also expects to find in America political freedom, technological sophistication, and an abundance of material goods, but the desire to get rich, a driving force in many immigrant stories, is not the focus of his American Dream. Aksenov's image of America is so strongly rooted in literary and cinematic sources that only on the second, more lasting encounter with the United States he starts to notice the visual and cultural reality behind the American myth. In his search for a place to call his own, Aksenov scrutinizes American cityscape through the prism of his expectations, his memory of Russia, and his aesthetic ideal. Although American places don't always meet his standards, Aksenov finds a location for settling down that combines such characteristics of his ideal America as freedom and wealth with the qualities of his remembered Russia—intellectual companionship and beauty. In spite of the initial disappointment in the quality of creative life in America, Aksenov becomes a productive member of its intellectual community. Paradoxically, Limonov received his recognition after publishing his book about a disgruntled unrecognized immigrant poet. Limonov's protagonist, who is, to an extent, modeled on the author, voices the bitter disappointment of an immigrant who has lost his illusions, sunk to the bottom of society, and refused to conform to its conventions. At the core of Eddie's American Dream was a belief in the freedom of creative expression and in the high status of writers and poets 
in America. When his futile efforts to get published disabuse Eddie of his inflated expectations, he turns his rancor towards the perceived injustices of American system. Eddie's thwarted ambition defines his social position as well as his unattachment to American places: although intimately familiar with the full range of New York's neighborhoods, he has no feeling of belonging to any.

${ }^{1}$ Since It's Me, Eddie blends some events of the author's life with fiction, it has been referred to as a novel. Because of its explicit, even obscene sexual scenes, it has been labeled pornographic. Olga Matich calls Limonov "an avant-garde provocateur," comparing his rejection of cultural elitism and his taboo breaking to those of Mayakovsky (526). Cynthia Simmons, in her discussion of aberrant discourse in post-Stalinist Russian literature, draws our attention to structural and linguistic details that "justify [the exclusion of this text] from the genre of autobiographical confession" (95). It is indeed important to distinguish between the author and the narrator here, and the book can and should be studied as a novel—which does not mean it cannot be also examined as an autobiographical text the exact place of which on the autobiography-fiction continuum might be hard to pinpoint.

${ }^{2}$ Bolshaya Sovetskaya Enciklopedia [Great Soviet Encyclopedia] published in 1969-1978 distinguished between "bourgeois cosmopolitanism" and "proletarian internationalism." Whereas the former is seen as a tool of imperialism that promotes "merging of nations through forceful assimilation," the latter considers "from the viewpoint of objective course of social development the prospect of gradual and voluntary rapprochement and then merging of nations, a lengthy process that results from the liberation and flourishing of nations" (“Kosmopolitism”). 
${ }^{3}$ Many of these books were published almost simultaneously in Russian by Ardis and in the English translations by Random House. During the same period of the 1980s, Aksenov's books also appeared in Britain and in other Western countries.

${ }^{4}$ D. Barton Johnson gives probably the fullest list of Aksenov's travels between 1962 and $1967-$ about thirteen trips to such places as Poland, Italy, Japan, India, Argentina, Yugoslavia, Austria, Switzerland, Bulgaria, Britain, and West Germany (182).

${ }^{5}$ In 1937 Aksenov's parents were arrested by Stalin's secret police. It is likely that he had a complex relationship to places of his childhood, which was spent in orphanages and with distant relatives. As a teenager, Aksenov lived with his mother who, after serving a ten-year sentence in prison camps, had to stay in the Magadan region of Siberia under police supervision. Aksenov's mother, Evgenia Ginsburg, described her arrest and imprisonment in two books, Journey into the Whirlwind and Within the Whirlwind. As a young adult, Aksenov studied in Kazan and Leningrad but moved to Moscow in the late 1950s, just in time to become a part of the city's exciting artistic and literary life during Khrushchev's "Thaw."

${ }^{6}$ During the last years of his life, Aksenov was working on an autobiographical novel Lendleazovskiye [Children of the Lend-lease] about his war-time childhood. This unfinished book was published posthumously in 2010 .

${ }^{7}$ In a 1983 interview with John Glad, Aksenov claims that he "never had any intention of repenting." He says that he was approached by the editors the magazine Yunost (Youth) and some writer friends who asked him "to write an article or do something to save their journal" from Khrushchev's wrath. All Aksenov did was write “a piece saying that [he] had written poorly, but from now on [he] would write well" (77).

${ }^{8}$ Aksenov's fortune changed after the 1968 invasion of Czechoslovakia and the following reactionary turn in the Communist Party's policy. When the government's relative leniency towards 
protesters and bold literary experiments ended, Aksenov, like many Soviet writers of the time, started writing "for the drawer," that is, with the knowledge that his work would never be accepted by the censors. Kustanovich notes that during the 1970s, Aksenov published only two children's books and "a hack book about the revolutionary Leonid Krasin" (32). Surprisingly, in 1975 Aksenov was allowed not only to accept the invitation of UCLA and travel to the United States but also to publish an account of this trip. Still, his major works of the 1970s — novels The Burn and The Island of Crimea - had to be smuggled out of the country and published abroad. In 1979, Aksenov was among the organizers and contributors of the uncensored self-published literary almanac Metropol. After this act of insubordination, he was forced to emigrate.

${ }^{9}$ The gendered language of Aksenov's simile is not as shocking to his Russian readers as it sounds in the English translation. Because in the Russian language all nouns have grammatical gender, personification of geographical names and abstract concepts usually takes the form of a gendered image. Names of most countries are feminine in Russian, so Russia, America, and scores of other political entities are perceived as female.

${ }^{10}$ More than two decades after the disintegration of the Communist system, public restrooms are still a problem in many places in the former Soviet Union. During my 2010 trip to Ukraine, in the heart of Kiev, in the midst of well-kept millennium-old tourist attractions and stunning modern high-rises, I encountered a no-toilet-seat, no-toilet paper, awful-stench-and-dirt relic of the Soviet past. The old building of the Academy of Sciences Library where I did my research featured an even more antiquated, albeit relatively clean, a-hole-in-the-tile-floor variety, also devoid of toilet paper, soap, or paper towels. The effect of American toilets on a Soviet traveler cannot be overestimated. A friend of mine who defected in 1990 told me that it was in a restroom somewhere along Route 1 in California that last doubts about staying in America left him and he realized clearly, "I am NEVER going back!" 
${ }^{11}$ This gendered image of New York as a broad results from an inexact translation. The grammatical gender of the word used in the Russian original, chuvak, or dude, is masculine. So is the grammatical gender of New York, which means that in Russian it cannot be personified as a female figure.

12 "A proud son of the Slavs and now a Finn and then a wild Tungus and a Kalmyk, the steppes' true friend" appear in the Pushkin's "Ya pamiatnik sebe vozdvig" ["I erected a monument to myself"], free translation of Horace's "Exegi Monumentum."

${ }^{13}$ Even in the prevalently anti-American post-Soviet culture, the magic and the romantic appeal of exotic geographic names survives. In a 2011 interview, Artemy Troitsky, a Moscow-based music critic, mentions the Illinois, an English-language rock group that appeared recently in city of Nizhny Novgorod on the Volga.

${ }^{14}$ The novel that resulted from Aksenov's fellowship at Kennan is Bumazhny Peizazh [Paperscape] published in 1982.

${ }^{15}$ It is worth noting that it took Nabokov eight years (1940-1948) of being a visiting lecturer in several schools to obtain a semi-permanent teaching position at Cornell and that American reading public showed no interest in his work until the late 1950s when the notoriety of Lolita brought him international renown.

${ }^{16}$ This title echoes Simmons's reference to Eddie's condition as "narcissistic rage" (107).

${ }^{17}$ Contrary to Eddie's predictions, the location he describes (Columbus Avenue near $100^{\text {th }}$ Street) became gentrified by the early 1990s when I lived on Columbus between $105^{\text {th }}$ and $106^{\text {th }}$ streets. Since then, the border of Spanish Harlem has been pushed even farther North, and my former rat hole of a sublet, as well as the crack joint on the floor below it, has been transformed into valuable real estate. 
18 "Zhlobby" is a transliteration of a derogatory Russian word that has no equivalent in English. It means someone who is simultaneously extremely miserly, narrow-minded, uncultured, and vulgar. 


\section{EPILOGUE}

Antin spent the last thirty years of her life without a home. In recent interviews, Hoffman mentions that she now lives in London. Aksenov retired from teaching and established residence in Biarritz, France, but spent most of his time in the post-Soviet Moscow where he died in 2009. Limonov moved to Paris in 1980 and returned to Russia as soon as the Soviet Union fell apart. Potocky-Tripodi still teaches at Florida International University, but will she move back to Prague when she retires? These outcomes suggest unconnectedness or unstable connections to American places. When I started this project, I hoped to understand how immigrants become attached to places in the new country. I did not discover a formula for place-connectedness. Rather, I found a complex tangle of relations with a number of variables, such as the American Dream, the pull of the native land, the time period, the age of the immigrant, and the reception he or she receives on arrival.

The imagined America plays a dual role in immigrant narratives: an antithesis to the country of origin and a lens of perception. Each immigrant writer discussed in this dissertation came to America with a mental image of the New World that was based on limited and distorted information. Whether in the rural setting and pre-technological communications of Antin's shtetl or in the isolation of the Cold-War Eastern Europe, emigrants pieced together from conflicting sources an idealized picture of America. As a response to the poverty, oppression, discrimination, and restrictions of their home country, their American Dream was based on an opposition between the familiar and the imagined worlds. Emigrants attributed to America characteristics deficient in their home country and expected to acquire wealth, equal treatment and equal opportunity, freedom from persecution and freedom of creative expression, and a cosmopolitan culture that values newcomers' contribution. These expectations, consistent with the precepts of the myth of American 
exceptionalism, determined immigrants' perception of America and their reaction to the first reallife encounter.

The binary structure of the American Dream underlies most immigrant texts, but the valuation of the old and the new place is hardly well-defined. In an effort to maintain a distinct contrast and to reject the place she left behind, Antin forces on the reader an enthusiastic praise of her new country - in contradiction to her own descriptions of Polotzk and of Boston slums. Hoffman reverses the emotional value of places, constructing Cracow as edenic and North America as aesthetically unappealing, incomprehensible and hostile. Both Hoffman and Potocky-Tripodi admit confusion about their identity and about their place in the new setting. Aksenov concedes some shortfalls in his ideal but also counts some gains and settles on the middle ground that reconciles the dream and the perceived places. Limonov's protagonist also finds himself in an inbetween position - of rejection rather than of acceptance, suspended rather than grounded, denouncing both the Soviet and the American systems, neither of which has use for his talents. In all examined texts, the prescribed opposition disintegrates.

A frustrated American Dream stands in the way of place-connectedness, and so does the absence of the American Dream. Antin defends her ideal in the face of contradictory evidence and even "owns" the City of Boston but has no attachment to the places where she lives. Similarly, Eddie admires New York City but does not belong in any neighborhood or with any social group. His anger at the indifferent and treacherous world alienates him from people and places. Hoffman has to formulate a dream that would motivate her ambition. Moving up to privileged social circles and prestigious places, she can never feel at home in either. Only in Aksenov's exceptional case, an adult immigrant writer who finds in America immediate recognition for his work can, with reservations, call the new place his home. 
With this absence of a rising narrative trajectory, the authors examined in this project overturn the model of immigrant autobiography established in the early 1900s. Then, the atmosphere of hostility to immigrants called for creating a triumphant story out of the shocks and hardships of the first encounter, for building up to an apotheosis of successful assimilation and belonging. Thus, Jacob A. Riis in The Making of an American describes years of hard work, poverty, and homelessness, still maintaining that "[a] chief reason why [he] liked this country from the very beginning was that it made no difference what a man was doing, so long as it was some honest, decent work" (184). By the end of the story, in which he painstakingly documents the setbacks and the accomplishments of the process, he is "made" an American. Antin, Riis's younger contemporary, already deviates from this model: her instant Americanness is a matter of a loudly declared conscious choice rather than of daily struggle and hard-won acceptance. For the late twentieth-century authors, becoming an American remains elusive. ${ }^{1}$ The well-integrated (Hoffman, Potocky-Tripodi, and Aksenov) as well as the outcast (Limonov's Eddie) state a varying degree of allegiance to their native cultures and their old places.

Even within a paradigmatic assimilation narrative, immigrant authors can admit an attachment to the places where they spent their childhood and youth, as does Elizabeth, Riis's wife, in his autobiography. She recalls her home town in Denmark "where to this day, in spite of [her] love for America, the air seems fresher, the meadows greener, the sea more blue, and where above it all the skylark sings his song clearer, softer, and sweeter than anywhere else in the world!" (152). Antin, whose autobiography aspires to the effect of an assimilation narrative, allows affectionate descriptions of Polotzk that call in question her rejection of the past and suggest a persistent, albeit unacknowledged, connection to her childhood place.

In texts of adult immigrants, the native place is often present as a point of comparison, but it is in childhood autobiographies that it appears in full force. Such is the case with Hoffman's book, 
where Cracow maintains a strong hold on the author's imagination and emotions. Hoffman's nostalgic longing for Cracow—or rather for its idealized image preserved in her memory—mediates her relation to American places and complicates attachment. In compensation for this unconnectedness, Hoffman develops complex ties to the English language, which becomes for her a substitute for place and home. Potocky-Tripodi notes a similar "imprint" of childhood places on her memory (73) and a strong, almost physical link to Prague, her native city. Thus, immigrant placeconnectedness implies transnational multivalent ties to physical, imagined, and remembered places.

Moreover, it is the very act of writing a story of one's emigration and immigration that establishes a connection to the new place and deposits the authors within the parameters of their new culture. In what John Paul Eakin calls "an intricate process of self-discovery and self-creation" (Fictions 3), immigrant autobiographers contribute their fictive selves to the expanding repertoire of American autobiographical personas: a persecuted refugee, a "greenhorn," a confused child, an assimilated immigrant, an angry outsider, a successful writer, and so on. Written in English, an immigrant autobiography demonstrates a high degree of acculturation and integration; written in the author's first language with an eye on subsequent translation, it signals an intention to be acculturated and integrated and to maintain a connection to another cultural system. In both cases, it blends the author's native and host cultures, becoming an artifact of cosmopolitan ethos. I hope so does my dissertation, based on my immigrant experience but written in English, in West Virginia. 
${ }^{1}$ When I talk about becoming American, I mean a cultural rather than a legal condition. Dealing with the U.S. Immigration and Naturalization Service could be a prolonged and nerve-racking process, and its successful outcome — becoming a citizen of the United States - does not necessarily result in the feeling of homecoming. 


\section{WORKS CITED}

Aksenov, Vassily. In Search of Melancholy Baby. Trans. Michael Henry Heim and Antonina W. Bouis. New York: Random House, 1985. Print.

---. "Kruglye Sutki Non-stop." [“Non-stop Around the Clock”]. Vassily Aksenov. Zolotaya Nasha Zhelezka [Our Golden Hardware]. Moscow: Eksmo, 2009. Print. 254-360.

---. "Lungs and Gills." Altogether Elsewhere: Writers in Exile. Ed. Marc Robinson. Boston: Faber and Faber, Inc., 1994. Print. 234-237.

---. "Residents and Refugees." Trans. Galya and Hugh Aplin. Under Eastern Eyes: The West as Reflected in Recent Russian Émigré Writing. New York: St. Martin's Press, 1992. Print. 4249.

---."Vasily Aksyonov." Conversations in Exile: Russian Writers Abroad. Ed. John Glad. Trans. Richard and Joanna Robin. Durham and London: Duke University Press, 1993. Print. 69-84. Alexander, Tania. Tania: Memories of the Lost World. Bethesda, MD: Adler \& Adler, 1987. Print. Alexandrova, Vera. “America and Americans in Soviet Literature.” Russian Review 2.2 (1943). 1926. JSTOR. Web. 10 July 2010.

Alroey, Gur. "Information, Decision, and Migration: Jewish Emigration from Eastern Europe in the Early Twentieth Century.” Immigrants \& Minorities 29.1 (2011): 33-63. JSTOR. Web. 6 April 2012.

Antin, Mary. From Plotzk to Boston. Princeton: Marcus Wiener Publishers, 1985. Print.

---. The Promised Land. Boston and New York: Houghton Mifflin Company, 1912. Print.

---. Selected Letters of Mary Antin. Ed. Evelyn Salz. Syracuse, NY: Syracuse University Press, 2000. Print.

---. They Who Knock at Our Gates: A Complete Gospel of Immigration. Boston, 1914. Google Book Search. Web. 18 October 2011. 
---. “A Zionist Confession of Faith.” The Maccabean: A Magazine of Jewish Life and Letters. February 1917. Ohio State University Book Depository. Web. 157-158. 12 March 2012. Appiah, Kwame Anthony. Cosmopolitanism: Ethics in a World of Strangers. New York: W.W. Norton, 2006. Print. Issues of Our Time.

Archdeacon, Thomas J. and Alfred Erich Senn. "Labor Emigration from Tsarist Russia: A Review Essay.” International Migration Review 24.1 (1990):149-160. JSTOR. Web. 25 March 2012.

Avramov, N. “They Didn't Consider it First but Have to Recon Now." Cartoon. Krasnoe Znamya [Kharkov] 15 February 1961: 3. Print.

Bakhtin, Mikhail. "Discourse in the Novel." The Dialogic Imagination. Ed. Michael Holquist. Austin, TX: Texas University Press, 1981. Print. 259-422.

Banerjee, Maria Nemcova. "Variations on American Themes: The Bride of Texas." Review of Contemporary Fiction 17.1 (1997): 149-156. Academic Search Complete. Web. 22 August 2010.

Baranczak, Stanislaw. "Tongue-Tied Eloquence: Notes on Language, Exile, and Writing." Altogether Elsewhere: Writers in Exile. Ed. Marc Robinson. Boston: Faber and Faber, Inc., 1994. Print. 242-251.

Behdad, Ali. A Forgetful Nation: On Immigration and Cultural Identity in the United States. Durham and London: Duke UP, 2005. Print.

Benatov, Joseph. "Demystifying the Logic of Tamizdat: Philip Roth's Anti-Spectacular Literary Politics." Poetics Today 30.1 (2009): 107-132. Academic Search Complete. Web. 22 August 2010.

A Bientel Brif: Sixty Years of Letters from the Lower East Side to the Jewish Daily Forward. Ed. Isaac Metzker. New York: Behrman House Inc., 1971. Print.

"Bloody Dictator and His Support." Cartoon. Krasnoe Znamya [Kharkov] 15 March 1961: 3. Print. 
Boelhower, William Q. Immigrant Autobiography in the United States: (Four Versions of the Italian American Self). Venice, Italy: Essedue Edizioni, 1983. Print.

Bogart, Leo. Premises for Propaganda: The United States Information Agency’s Operating Assumptions in the Cold War. New York: The Free Press, 1976. Print.

Boyd, Brian. Vladimir Nabokov: The American Years. Princeton: Princeton University Press, 1991. Print.

Boym, Svetlana. Death in Quotation Marks: Cultural Myths of the Modern Poet. Cambridge, MA: Harvard University Press, 1991. Print.

Braverman, William A. “The Emergence of Unified Community, 1880-1917.” The Jews of Boston. Ed. Jonathan D.Sarna, Ellen Smith and Scott-Martin Kosofsky. New Haven: Yale University Press, 2005. Print. 65-84.

Bray, Daniel. Pragmatic Cosmopolitanism: Representation and Leadership in Transnational Democracy. New York: Palgrave, 2011. Print.

Brodkin, Karen. How Jews Became White Folks and What That Says About Race in America. New Brunswick, NJ: Rutgers University Press, 1998. Print.

Brooks, Stephen. As Others See US: The Causes and Consequences of Foreign Perceptions of America. Toronto, ON: Broadview Press, 2006. Print.

Brown, Michael. "Divergent Paths: Early Zionism in Canada and the United States.” Jewish Social Studies 44.2 (1982): 149-168. JSTOR. Web. 29 March 2012.

Buell, Lawrence. Writing for an Endangered World: Literature, Culture, and Environment in the U.S. and Beyond. Cambridge, MA, and London: Harvard UP, 2001. Print.

Bushee, Frederick A. "Ethnic Factors in the Population of Boston." Publications of the American Economic Association $3^{\text {rd }}$ ser. 4.2 (1903): 1-171. Web. JSTOR. 23 February 2012. 
---. “The Invading Host.” Americans in Process: A Settlement Study. Ed. Robert A. Wood. 1903. New York: Arno Press and the New York Times, 1970. Print. The American Immigration Collection. 40-70.

Čapek, Thomas. The Czechs (Bohemians) in America: A Study of Their National, Cultural, Political, Social, Economic, and Religious Life. Boston: Houghton Mifflin, 1920. Print.

Caute, David. The Dancer Defects: The Struggle for Cultural Supremacy During the Cold War. Oxford: Oxford University Press, 2003. Print.

Chavchavadze, Paul. Marie Avilov: Pilgrimage Through Hell. Englewood Cliffs, NJ: Prentice Hall, Inc. 1968. Print.

Chistyakov, S. "Looking for a Job. Looking for Entertainment." Cartoon. Krasnoe Znamya [Kharkov] 29 August 1961: 4. Print.

---. "Through the Air Corridor." Cartoon. Krasnoe Znamya [Kharkov] 23 September 1961: 3. Print. Chiswick, Barry R. and Paul W. Miller. "Immigrant Enclaves, Ethnic Goods, and the Adjustment Process." From Arrival to Incorporation: Migrants to the U.S. in the Global Era. Eds. Elliott R. Barkan, Hasia Diner, and Alan M. Kraut. New York and London: New York UP, 2008. 80-93. Print.

Clark, Katerina. Moscow, the Fourth Rome: Stalinism, Cosmopolitanism and the Evolution of Soviet Culture, 1931-1941. Cambridge, MA: Harvard University Press, 2011. WVU Electronic Book Collection. Web. 20 March 2012.

Condee, Nancy and Vladimir Padunov. "The ABC of Russian Consumer Culture: Reading, Rating, and Real Estate." Soviet Hieroglyphics: Visual Culture in Late Twentieth-Century Russia. Ed. Nancy Condee. Bloomington and Indianapolis: Indiana University Press, 1995. Print. $130-172$. 
Connolly, James. J. The Triumph of Ethnic Progressivism: Urban Political Culture in Boston, 19001925. Cambridge, MA: Harvard University Press, 1998. Print.

“Constitution of the Immigration Restriction League." Harvard University Library Open Collections Program. The President and Fellows of Harvard College. 2012. Web. 3 March 2012.

Cooley, Marcela. Personal Interview. 8 November 2010.

Cresswell, Tim. Place: A Short Introduction. Malden, MA: Blackwell Publishing, 2004. Print. Cullen, Jim. The American Dream: A Short History of an Idea That Shaped a Nation. Oxford and New York: Oxford UP, 2003. Print.

Dainotto, Roberto M. Place in Literature: Regions, Cultures, Communities. Ithaca and London: Cornell UP, 2000. Print.

Daniels, Roger. Coming to America: A History of Immigration and Ethnicity in American Life. New York: Harper Perennial, 1990. Print.

Dearborn, Mary V. Pocahontas’s Daughters: Gender and Ethnicity in American Culture. New York: Oxford University Press, 1986. Print.

Djilas, Aleksa. "What We Think of America.” Granta 77 (2002): 25-29. Print.

Douglas, Kate. Contesting Childhood: Autobiography, Trauma, and Memory. New Brunswick, NJ: Rutgers University Press, 2010. Print.

Dunlop, John B. "Vasilii Aksenov's Novels Ozhog and Ostrov Krym.” Aspects of Modern Russian and Czech Literature. Ed. Arnold McMillin. Columbus, OH: Slavica Publishers, Inc., 1989. Print. 118-128.

Eakin, Paul John. Fictions in Autobiography: Studies in the Art of Self-Invention. Princeton UP, 1988. Print. 
---. Introduction. American Autobiography: Retrospect and Prospect. Ed. Paul John Eakin. Madison, WI: University of Wisconsin Press, 1991. Print. 3-22.

Elwell, Sue Levi. “Josephine Lazarus.” Jewish Women: A Comprehensive Historical Encyclopedia. Jewish Women's Archive. 2012. Web. 3 March 2012.

Emerson, Ralph Waldo. "History." Selected Writings. Ed. Brooks Atkinson. New York: The Modern Library, 1950. Print.

Foucault, Michel. The Archeology of Knowledge. Trans. A.M. Sheridan Smith. New York: Pantheon Books, 1972. Print.

Georgiou, Myria. Diaspora, Identity and the Media: Diasporic Transnationalism and Mediated Spatialities. Cresskill, NJ: Hampton Press, Inc., 2006. Print.

Gerstle, Gary. "The Immigrant as Threat to American Society: A Historical Perspective." From Arrival to Incorporation: Migrants to the U.S. in the Global Era. Eds. Elliott R. Barkan, Hasia Diner, and Alan M. Kraut. New York and London: New York UP, 2008. Print.

Gieystor, Alexander, Stefan Kieniewicz, Emanuel Rostworowski, Janusz Tazbir and Henryk Wereszycki. History of Poland. Warszawa: Polish Scientific Publishers, 1968. Print.

Goodwin, James. Autobiography: The Self Made Text. New York: Twayne Publishers, 1993. Print. Studies in Literary Themes and Genres.

Gorky, Maxim. The City of the Yellow Devil. Moscow: Progress Publishers, 1972. Print.

Goscilo, Helena. "The Gendered Trinity of Russian Cultural Rhetoric Today—or the Glyph of the H[i]eroine." Soviet Hieroglyphics: Visual Culture in Late Twentieth-Century Russia. Ed. Nancy Condee. Bloomington and Indianapolis: Indiana University Press, 1995. Print. 68-92. Grabbe, Paul. Windows on the River Neva. New York: Pomerica Press Ltd, 1977. Print. Grady, Eve Garette. “American Engineers in Russia.” Saturday Evening Post 14 March1931, 42-48. Academic Search Complete. Web.19 August 2010. 
Graffy, Julian. "Émigré Experience of the West as Related to Soviet Journals." Under Eastern Eyes: The West as Reflected in Recent Russian Émigré Writing. New York: St. Martin's Press, 1992. Print. 115-157.

Grant, Madison. The Passing of a Great Race, or the Racial Basis of European History. New York: Charles Scribner's Sons, 1918. Print.

Grewal, Inderpal. Transnational America: Feminism, Diaspora, Neoliberalisms. Durham and London: Duke UP, 2005. Print.

Grogin, Robert C. Natural Enemies: The United States and the Soviet Union in the Cold War, 19171991. Lanham, MD: Lexington Books, 2001. Print.

Grose, Howard B. Aliens or Americans? New York: Young People's Missionary Movement, 1906. Print. Forward Mission Studies Courses.

Grubrova, Mila. Personal Interview. 8 November 2010.

Grunin A. "Intercontinental Bench." Cartoon. Krasnoe Znamya [Kharkov] 18 May 1961: 4. Print. ---. "The American Clock." Cartoon. Krasnoe Znamya [Kharkov] 15 September 1961: 4. Print.

---. "The Rise of Ruble; the Decline of Dollar." Cartoon. Krasnoe Znamya [Kharkov] 3 January 1961: 3. Print.

Gurewich, David. Travels with Dubinsky and Clive. New York: Viking, 1987. Print.

Hanasz, Waldemar. "Engines of Liberty: Cars and the Collapse of Communism." Cei.org. Competitive Enterprise Institute, 30 November1999. PDF file. 22 November 2010.

Handlin, Oscar. Foreword. The Promised Land. By Mary Antin. Boston: Houghton Mifflin Company, 1969. Print. v-xv.

---. The Uprooted: The Epic Story of the Great Migrations That Made the American People. Philadelphia: University of Pennsylvania Press, 2002. Print. 
Hirsch, Marianne. "Pictures of a Displaced Girlhood.” Displacements: Cultural Identities in Question. Ed. Angelika Bammer. Bloomington, IN: Indiana University Press, 1994. Print. 71-89.

Hoffman, Eva. Lost in Translation: A Life in a New Language. New York: E.P. Dutton, 1989. Print. Hron, Madelaine. Translating Pain: Immigrant Suffering in Literature and Culture. Toronto: University of Toronto Press, 2009. Print.

Ilf, Ilya and Eugene Petrov. Little Golden America: Two Famous Soviet Humorists Survey the United States. Trans. Charles Malamuth. New York: Farrar \& Rinehart, Inc., 1937. Print. Jaher, Frederic Cople. A Scapegoat in the New Wilderness: The Origins and Rise of Anti-Semitism in America. Cambridge, MA: Harvard University Press, 1994. Print.

Jaret, Charles. "Troubled by Newcomers: Anti-immigrant Attitudes and Actions During Two Eras of Mass Migration.” Mass Migration to the United States: Classical and Contemporary Periods. Ed. Pyong Gap Min. Walnut Creek, CA: Altamira Press, 2002. Print. 21-63.

The Jews of Boston. Ed. Jonathan D.Sarna, Ellen Smith and Scott-Martin Kosofsky. New Haven: Yale University Press, 2005. Print.

Johnson, Barton D. “Aksënov as Travel Writer: Round the Clock, Non-Stop.” Vasiliy Pavlovich Aksënov: A Writer in Quest of Himself. Columbus, OH: Slavica Publishers, Inc., 1984. Print.182-192.

Johnson, J.J. "V.P. Aksenov: A Literary Biography." Vasiliy Pavlovich Aksënov: A Writer in Quest of Himself. Columbus, OH: Slavica Publishers, Inc., 1984. Print. 32-52.

Kaplan, Caren. Questions of Travel: Postmodern Discourses of Displacement. Durham and London: Duke UP, 1996. Print.

Karadja, Kyra. Kyra’s Story: Reminiscences of a Girlhood in Revolutionary Russia. New York: William Morrow and Company, 1975. Print. 
Kellman, Stephen G. "Lost in a Promised Land: Eva Hoffman Revises Mary Antin.” Prooftexts. 18 (1998): 149-159. MLA International Bibliography. Web. 26 September 2010.

Kemp, Peter. Citizen of the World: The Cosmopolitan Ideal for the Twenty-First Century. Trans.

Russell L. Dees. New York: Humanity Books, 2011. Print. Contemporary Studies in Philosophy and the Human Sciences.

Kerblay, Basile. Modern Soviet Society. Trans. Rupert Swyer. New York: Pantheon Books, 1983. Print.

Klíma, Ivan. "Return to Prague: A Conversation between Ivan Klíma and Philip Roth.” The Spirit of Prague and Other Essays. Trans. Paul Wilson. New York: Granta Books, 1994. Print.

---. "What We Think of America." Granta 77 (2002): 50-53. Print.

Koláŕ, Stanislav. “The Czech Reception of Sister Carrie.” Dreiser Studies 32.1 (2001): 56-63. Academic Search Complete. Web. 22 August 2010.

Korolenko, Vladimir G. In a Strange Land. Trans. Gregory Zilboorg. New York: Bernard G. Richards Co, Inc., 1925. Print.

Kort, Wesley A. Place and Space in Modern Fiction. Gainsville, FL: UP of Florida, 2004. Print. Kosek, Helena. "American Themes in The Bride of Texas." Review of Contemporary Fiction 17.1 (1997): 141-148. Academic Search Complete. Web. 22 August 2010.

“Kosmopolitism.” Bolshaya Sovetskaya Enciklopedia [Great Soviet Encyclopedia]. Academic. 2010. Web. 16 April 2012.

Kula, Marcin. "Emigration from a Communist Country: Both Economic and Political: A PostCommunist Perspective.” Journal of American Ethnic History. 16.1 (1996): 47-54. Academic Search Complete. Web. 12 September 2010.

Kustanovich, Konstantin. The Artist and the Tyrant: Vassily Aksenov's Works in the Brezhnev Era. Columbus, OH: Slavica Publishers, Inc., 1992. 
Lauridsen, Inger and Per Dalgård. "Interview with V.P. Aksenov, Washington, D.C., December, 1982." Trans. Margaret Bradley. Vasiliy Pavlovich Aksënov: A Writer in Quest of Himself. Columbus, OH: Slavica Publishers, Inc., 1984. Print. 14-25.

Lazarus, Josephine. "Higher Education: A Word to Women.” The Century 41.2 (1890): 315-316. Making of America. Cornell University Library. 2012. Web. 14 February 2012.

---. “Louisa May Alcott.” The Century 42.1 (1891): 59-68. Making of America. Cornell University Library. 2012. Web. 14 February 2012.

---. Madame Dreyfus: An Appreciation. New York: Brentano’s. 1899. Microfilm. History of Women. 1921. Vanderbilt University Library. 15 February 2012.

---. "Notable Women: Margaret Fuller." The Century 45.6 (1893): 923-934. Making of America. Cornell University Library. 2012. Web. 14 February 2012.

---. Rev of From Plotzk to Boston by Mary Antin. The Critic 34. 862 (1899): 317-318. American Periodicals Series III. ProQuest. 2010. Web. 14 February 2012.

---. The Spirit of Judaism. 1895. Freeport, NY: Books for Libraries Press, 1972. Print. Essay Index Reprint Series.

Levine, Madeline. "Eva Hoffman: Forging a Postmodern Identity." Living in Translation: Polish Writer in America. Ed. Halina Stephan. Amsterdam: Rodopi, 2003. Print. 215-233.

Lichtenstein, Diane. "Emma Lazarus.” Jewish Women: A Comprehensive Historical Encyclopedia. Jewish Women's Archive. 2012. Web. 3 March 2012.

Limonov, Edward. It’s Me, Eddie. New York: Random House, 1983. Print.

---. "My Nacional'nyi Geroi.” [“We the National Hero"]. Apollon. 1977. 57-64. WorldCat. Web. 18 April 2012.

Lipovetsky, Mark. Russian Postmodernist Fiction: Dialogue with Chaos. Ed. Eliot Borenstein. Armonk, NY: M.E. Sharpe, 1999. Print. 
Lutwack, Leonard. The Role of Place in Literature. Syracuse, NY: Syracuse UP, 1984. Print.

Marciniak, Katarzyna. Alienhood: Citizenship, Exile, and the Logic of Difference. Minneapolis and London: U of Minnesota P, 2006. Print.

Margulies, Sylvia R. The Pilgrimage to Russia: The Soviet Union and the Treatment of Foreigners, 1924-1937. Madison: University of Wisconsin Press, 1968. Print.

Matich, Olga. “The Moral Immoralist: Edward Limonov's Èto Ja-Èdička.” The Slavic and East European Journal 30.4 (1986): 526-540. JSTOR. Web. 23 November 2010.

Mayakovsky. Trans. and ed. Herbert Marshall. New York: Hill and Wang, 1965.

Mazur, Allan. A Romance in Natural History: The Lives and Works of Amadeus Grabau and Mary Antin. Syracuse, NY: Garret, 2004. Print.

McDowell, Linda. Gender, Identity, and Place: Understanding Feminist Geographies. Minneapolis: U of Minnesota Press, 1999. Print.

McMillin, Arnold. "Western Life as Reflected in Aksenov's Work before and after Exile." Under Eastern Eyes: The West as Reflected in Recent Russian Émigré Writing. New York: St. Martin's Press, 1992. Print. 50-61.

Meagher, Timothy J. "The Importance of Being Italian: Italian Americans in American Popular Culture, 1960s to 1990s.” From Arrival to Incorporation: Migrants to the U.S. in the Global Era. Eds. Elliott R. Barkan, Hasia Diner, and Alan M. Kraut. New York and London: New York UP, 2008. 185-213. Print.

“Merchant Marines on Strike.” Krasnoe Znamya [Kharkov] 29 July 1961: 3. Print. Mesropova, Olga. "From Infantile Regression to Post-Tourist Breakthrough: America in Two Russian Travelogues of the 1990s.” The Slavic and East European Journal 48.1 (2004): 2740. Academic Search Complete. Web. 10 July 2010. 
Mikhailov, N. N. and Z. V. Kossenko. Those Americans: A Travelogue. Trans. Joseph Suhadolc and Virginia Moseley. Chicago: H. Regnery Co, 1962. Print.

Miller, Herbert Adolphus. "What Woodrow Wilson and America Meant to Czechoslovakia." Czechoslovakia: Twenty Years of Independence. Ed. Robert J. Kerner. Berkley, CA: University of California Press. 1940. Print. 71-90.

Miller, Nancy K. "I Killed My Grandmother: Mary Antin, Amos Oz, and the Autobiography of a Name.” Biography 30.3 (2007): 319-341. MLA International Bibliography. Web. 26 September 2010 .

Min, Pyong Gap. Introduction. Mass Migration to the United States: Classical and Contemporary Periods. Ed. Pyong Gap Min. Walnut Creek, CA: Altamira Press, 2002. Print. 1-19. Morley, Charles. Introduction. Portrait of America: Letter of Henry Sienkiewicz. Ed. and trans. Charles Morley. New York: Columbia University Press, 1959. ix-xix. Print.

Ognivtsev, N. “'Freedom’ American Style.” Cartoon. Krasnoe Znamya [Kharkov] 13 December 1961: 3. Print.

---. “In the So-called 'Free’ World.” Cartoon. Krasnoe Znamya [Kharkov] 21 November 1961: 3. Print.

---. "Parasitic Tumor.” Cartoon. Krasnoe Znamya [Kharkov] 20 September 1961: 3. Print.

Ong, Aihwa. "Fenshui and the Limits to Cultural Accumulation." Flexible Citizenship: The Cultural Logic of Transnationality. Durham \& London: Duke University Press, 1999. 87-109. Print.

Orleck, Annelise. The Soviet Jewish Americans. Westport, CT, and London: Greenwood Press, 1999. Print.

O’Toole, Fintan. "What We Think of America.” Granta 77 (2002): 61-64. Print. Papashvily, George and Helen Waite Papashvily. Anything Can Happen. New York: Harper \& Brothers, 1945. Print. 
Papastergiadis, Nikos. The Turbulence of Migration: Globalization, Deterritorialization, and Hybridity. Malden, MA: Polity Press, 2000. Print.

Parkman, Mary Rosetta. Heroines of Service. Freeport, NY: Books for Libraries Press, 1969.

Patterson, David. Exile: The Sense of Alienation in Modern Russian Letters. Lexington, KY: The University Press of Kentucky. 1995. Print.

Pease, Donald E. “C.L.R. James, Moby Dick, and the Emergence of Transnational American Studies.” The Futures of American Studies. Eds. Donald E. Pease and Robyn Wiegman. Durham \& London: Duke UP, 2002. 134-163.

---. Introduction. Re-Framing the Transnational Turn in American Studies. Eds. Winfried Fluck, Donald E. Pease and John Carlos Rowe. Hanover, NH: Dartmouth College Press, 2011. Print. 1-46.

---. The New American Exceptionalism. Minneapolis: University of Minnesota Press, 2009. Print. Critical American Studies Series. Ed. George Lipsitz.

Pekárková, Iva. Gimme the Money. Trans. Raymond Johnston and Iva Pekárková. London: Serpent's Tail, 2000. Print.

Peskov, Vasily and Boris Strelnikov. Zemlya za Okeanom [The Land Beyond the Ocean]. Librusec. N.d. Web. 13 April 2012.

Pessen, Edward. “Appraising American Cold War Policy by its Means of Implementation. Reviews in American History 18.4 (1990): 453-465. JSTOR. Web. 25 March 2012.

Pichova, Hana. “Czech Culture Question.” Message to the author. 28 June 2010. E-mail.

Pilnyak, Boris. “OKay: Amerikansky Roman” [OK: An American Novel]. Izbrannye Proizvedenia [Selected Works]. Moscow: Khudozhestvennaya Literatura, 1976. Print. 443-675.

Portes, Alejandro and Rubén G. Rumbaut. Immigrant America: A Portrait. $3^{\text {rd }}$ edition. Berkley, Los Angeles, London: University of California Press, 2006. Print. 
“Postanovlenie Soveta Ministrov SSSR ot 27 Maya 1961, № 468. Ob uluchshenii izuchenia inostrannyh yazykov." ["Resolution of the USSR Council of Ministers May 27, 1961, \#468. On the Improvement of Foreign Languages Instruction”]. Konsultant.ru. KonsultantPlus. N.d. Web. 8 April 2012.

Potocky-Tripodi, Miriam. Best Practices for Social Work with Refugees and Immigrants. New York: Columbia University Press, 2002. Print.

---. Where is My Home?: A Refugee Journey. New York: Writer's Showcase, 2000. Print.

Prchal, Tim. "The Bohemian Paradox: My Ántonia and the Popular Images of Czech Immigrants." MELUS 29.2 (2004): 3-25. Academic Search Complete. Web. 22 August 2010.

Prilepin, Zachar. "Yego Imya_Eduard Limonov" ["His Name is Edward Limonov"]. limonov2012.ru. n.p. 2012. Web. 29 January 2012.

Program of the Communist Party of the Soviet Union. New York: International Publishers Co, Inc., 1963. Print.

Proffer, Carl R. "Nadezhda Mandelstam.” The Widows of Russia and Other Writing. Ann Arbor: Ardis, 1987.13-62. Print.

---. Preface and Introduction. Soviet Criticism of American Literature in the Sixties: An Anthology. Ed. Carl R. Proffer. Ann Arbor: Ardis, 1972. ix-xxii. Print.

Proffer, Ellendea. "Nabokov's Russian Readers.” Nabokov: Criticism, Reminiscences, Translations and Tributes. Eds. Alfred Appel, Jr. and Charles Newman. Evanston, IL: Northwestern University Press, 1970. Print. 253-260.

Rapoport, Alexander. "The Russian Broadcasts of the Voice of America.” Russian Review. 16.3 (1957): 3-14. JSTOR. Web. 23 November 2010.

Read, Christopher. The Making and Breaking of the Soviet System: An Interpretation. New York: Palgrave, 2001. Print. 
Reilly, Alayne. America in Contemporary Soviet Literature. New York: New York University Press, 1971. Print.

Reimers, David M. and Harold Troper. "Canadian and American Immigration Policy Since 1945.” Immigration, Language, and Ethnicity: Canada and the United States. Ed. Barry R. Chiswick. Washington, DC: The AEI Press, 1992. Print. 15-54.

Renkiewicz, Frank. The Poles in America, 1608-1972: A Chronology \& Fact Book. Dobbs Ferry, NY: Oceana Publications, Inc., 1973. Print. Ethnic Chronology Series Number 9.

Riis, Jacob A. The Making of an American. New York: Grosset \& Dunlop Publishers, 1901. Print. Rodimtsev, Alexei. Personal Interview. 18 November 2010.

Rokosz-Piejko, Elżbieta. “Child in Exile-Mary Antin’s and Eva Hoffman’s Versions of Exiled Childhood.” Exile: Displacements and Misplacements. Eds. Wojciech H. Kalaga and Tadeusz Rachwał. Frankfurt am Main: Peter Lang, 2001. Literary and Cultural Theory Vol. 11. Print. 173-181.

Rosenfeld Alvin H. and Moshe Davis. "Promised Land(s): Zion, America, and American Jewish Writers.” Jewish Social Studies, New Series 3.3 (1997): 111-131. JSTOR. Web. 29 March 29, 2012.

Rossiyskaya Natsionalnaya Biblioteka. Generalny Alfavitny Catalog Knig na Russkom Yazyke (1725-1998). [Russian National Library. General Alphabetical Catalog of Russian-language Books]. 2001-2010.

Rushdie, Salman. Imaginary Homelands: Essays and Criticism 1981-1991. London: Granta Books, 1992. Print.

Russian America Yellow Pages. Webideas. 1998. Web Ideas International. Web. 25 July 2010 
Ryan, Karen L. "Imagining America: Il'f and Petrov's "Odnoetazhnaia Amerika" and Ideological Alterity." Canadian Slavonic Papers / Revue Canadienne des Slavistes 44.3/4 (2002): 263277. JSTOR. Web. 6 April 2012.

Said, Edward. "No Reconciliation Allowed." Letters of Transit: Reflections on Exile, Identity, Language, and Loss. Ed. André Aciman. New York: New Press, 1999. Print. 87-114.

---."On Palestinian Identity: Conversation with Edward Said." Salman Rushdie. Imaginary Homelands: Essays and Criticism 1981-1991. London: Granta Books, 1992. 166-184. Print. Sakwa, Richard. The Rise and Fall of the Soviet Union, 1917-1991. London and New York: Routledge, 1999. Print. Rutledge Sources in History.

Saltz, Evelyn. Introduction. Selected Letters of Mary Antin. Ed. Evelyn Salz. Syracuse, NY: Syracuse University Press, 2000. Print. xiii-xxiv.

Sammons, Jeffrey L. Ideology, Mimesis, Fantasy: Charles Sealsfield, Friedrich Gerstäcker, Karl May, and Other German Novelists of America. Chapel Hill: University of North Carolina Press, 1998. Print. University of North Carolina Studies in Germanic Languages and Literature 121.

Shavelson, Susanne A. “Anxieties of Authorship in Autobiographies of Mary Antin and Eliza Greenblatt.” Prooftext 18 (1998): 161-186. Web. MLA International Bibliography 26 September 2010 .

Shea, Daniel B. "The Prehistory of American Autobiography.” American Autobiography: Retrospect and Prospect. Ed. Paul John Eakin. Madison, WI: University of Wisconsin Press, 1991. Print. 23-46.

Sheffer, Jolie A. "Recollecting, Repeating, and Walking Through: Immigration, Trauma, and Space in Mary Antin's The Promised Land.” MELUS. 35.1 (2010). Print. 141-166. 
Shipler, David K. Broken Idols, Solemn Dream: A Provocative Look at the Russian People. New York: Penguin Books, 1983. Print.

Shlapentokh, Dmitry. “The End of the Russian Idea.” Studies in Soviet Thought 43.3 (1992): 199217. JSTOR.Web. 25 March 2012.

Sienkiewicz, Henryk. After Bread: A Story of Polish Emigrant Life to America. Trans. Vatslav A. Hlasko and Thomas H. Bullick. New York: R.F. Fenno \& Company, 1897. Print.

---. Portrait of America: Letters of Henry Sienkiewicz. Ed. and trans. Charles Morley. New York: Columbia University Press, 1959. Print.

Simmons, Cynthia. Their Father's Voice: Vassily Aksenov, Venedikt Erofeev, Eduard Limonov, and Sasha Sokolov. New York: Peter Lang, 1993. Print. Middlebury Studies in Russian Language and Literature. Ed. Thomas R. Beyer, Jr. Vol.4.

Sinclair, Upton. The Jungle. New York: Barnes \& Noble Classics, 2003. Print.

Sís, Peter. The Wall: Growing Up Behind the Iron Curtain. New York: Frances Foster Books Farrar, Straus and Giroux, 2007. N.pag. Print.

Škvorecký, Josef. “Drops of Jazz in My Fiction.” Black American Literature Forum 25.3 (1991): 621-32. MLA International Bibliography. Web. 22 August 2010.

Smith, Hedrick. The Russians. New York: Ballantine Books: 1976. Print.

Smith, Sidonie and Julia Watson. Introduction. Getting a Life: Everyday Uses of Autobiography. Eds. Sidonie Smith and Julia Watson. Minneapolis: University of Minnesota Press, 1998. Print. 1-24.

Solecki, Sam. “An Interview with Josef Škvorecký.” Review of Contemporary Fiction 17.1 (1997): 82-91. Academic Search Complete. Web. 22 August 2010.

Solors, Werner. Beyond Ethnicity: Consent and Descent in American Culture. New York and Oxford: Oxford UP, 1986. 
---. Introduction. The Promised Land. By Mary Antin. London: Penguin Books. 1997. Print. xi-lvi. Sosin, Gene. Sparks of Liberty: An Insider's Memoir of Radio Liberty. University Park, PA: The Pennsylvania State University Press, 1999. Print.

Spechler, Dina R. Permitted Dissent in the USSR: Novy Mir and the Soviet Regime. New York: Prager Publishers, 1982. Print.

Spenser, Robert. Cosmopolitan Criticism and Postcolonial Literature. New York: Palgrave, 2011. Print.

“Steel Production.” Cartoon. Krasnoe Znamya [Kharkov] 14 November 1961: 2. Print.

St. John de Crevècoeur, J. Hector. Letters from an American Farmer. Ed. Albert Stone. New York: Penguin Books, 1981. Print.

Stites, Richard. Russian Popular Culture: Entertainment and Society since 1900. Cambridge: Cambridge University Press, 1992. Print. Cambridge Soviet Paperbacks 7.

Stolz, Benjamin and Michael Makin. "Joseph Brodsky." Slavic Languages and Literatures. The University of Michigan, n.d. Web. 5 August 2011.

Surkov, Alexei. "Raise Your Voice, Honest People.” Vo Vlasti Zheltogo Diavola [In the Grip of the Yellow Devil]. Voennoe Izdatelstvo: Moscow, 1985. 114-115.

---. “To a Chicago Factory Owner.” Vo Vlasti Zheltogo Diavola [In the Grip of the Yellow Devil]. Voennoe Izdatelstvo: Moscow, 1985. 113.

Tess, Tatiana. Amerikanki [American Women]. Moscow: Detskaya Literatura, 1966. Print. “Today in the USA.” Krasnoe Znamya [Kharkov] 13 May 1961: 3. Print.

Thomas, Robert McG., Jr. "Willis Conover Is Dead at 75; Aimed Jazz at the Soviet Bloc." Nytimes.com. The New York Times Company, 19 May 1996. Web. 18 September 2010. 
Timrava. "That Alluring Land.” That Alluring Land: Slovak Stories by Timrava. Ed. and trans. Norma L. Rudinsky. Pittsburgh and London: University of Pittsburgh Press. 1992. Print. 95129.

Troitsky, Artemy. Interview by Seva Gakkel. Priznaki Vremeni. Issue 49. Art Podfm. St. Petersburg, Russia. July 8, 2011. Web. 19 July 2011.

Tuan, Yi-Fu. Topophilia: A Study of Environmental Perception, Attitudes, and Values. New York, Columbia UP, 1974, 1990.

Yurchak, Alexei. Everything Was Forever, Until It Was No More: The Last Soviet Generation. Princeton: Princeton University Press, 2006. Print.

"United States of America. Fort Bragg in North Carolina.” Cartoon. Krasnoe Znamya [Kharkov] 6 August 1961: 4. Print.

U.S. Immigration and Naturalization Laws and Issues: A Documentary History. Eds. Michael LeMay and Elliot Robert Barkan. Westport, CT: Greenwood Press, 1999. Print. Primary Documents in American History and Contemporary Issues.

Vail, Pyotr and Alexander Genis. 60-e. Mir Sovetskogo Cheloveka. [The '60-s. The World of the Soviet Person]. Ann Arbor: Ardis, 1989. Print.

Waxman, Chaim I. “The Sociohistorical Background and Development of America's Jews.” Jews in America: A Contemporary Reader. Eds. Roberta Rosenberg Farber and Chaim I. Waxman. Hannover and London: Brandeis University Press, 1999. Print. 7-15.

Williams, Raymond. The Country and the City. New York: Oxford University Press, 1973. Print. Winter, Molly Crumpton. American Narratives: Multiethnic Writing in the Age of Realism. Baton Rouge: Louisiana State University Press, 2007. Print.

Women, Autobiography, Theory: A Reader. Ed. Sidonie Smith and Julia Watson. Madison: University of Wisconsin Press, 1998. Print. 
Yezierska, Anzia. “How I Found America.” Hungry Hearts. New York: Penguin Books, 1997. Print.

“Zakon RSFSR ot 27.10.1960 'Ob Utverzhdenii Ugolovnogo Kodeksa RSFSR' (Vmeste s 'Ugolovnym Kodeksom RSFSR')” [October 27, 1960 Act of RSFR 'Adoption of the Criminal Code of RSFSR' (With the 'Criminal Code of RSFSR'). Zaki.ru. N.p. n.d. Web. 7 April 2012.

Zaslavsky, Victor and Robert J. Brym. Soviet-Jewish Emigration and Soviet Nationality Policy. New York: St. Martin’s Press, 1983. Print.

Zubok, Vladislav. Zhivago’s Children: The Last Russian Intelligentsia. Cambridge, MA: The Belknap Press of Harvard University Press, 2009. Print. 
Rodimtseva 268

\section{APPENDIX: ILLUSTRATIONS}




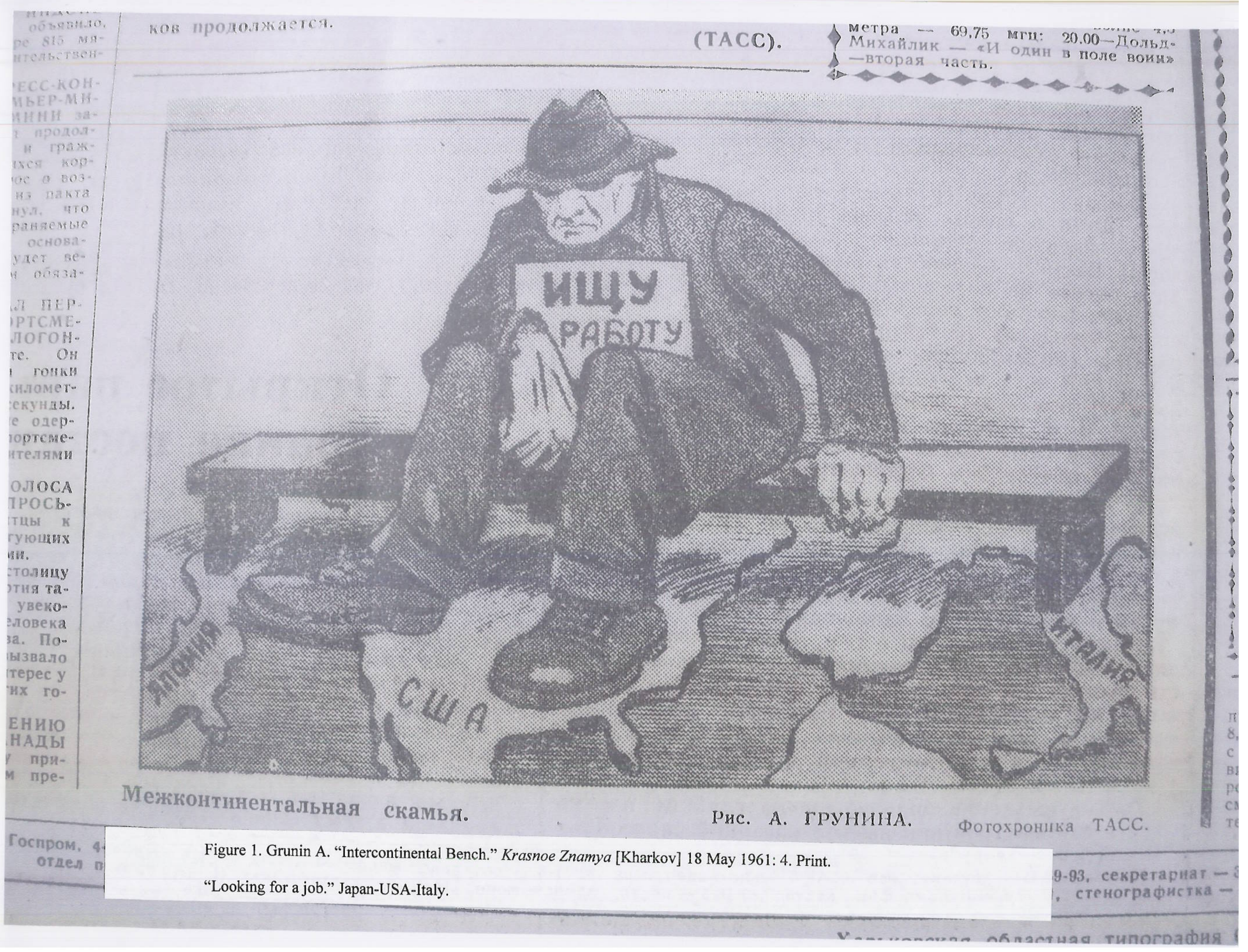


lac He 8 Moндоне.

13 Макмнллана спросипугает ли его нынешоложение дел, котда обенх сторон устремируг на друга, премьерр ответил: «Я думаю, ) раздувается печатью. не собирастся восвать TOГO».

ткуя это заявление тана, газеты выделяют

\section{$=$ \\ ) Ка ия}

с территории Западпина неизвестными лиПрезндиум народной сообщил, что один эйских ранен. Кроме зокаторы нанесли по7 потраничным 1.

co-

\section{ЗИЛИК}

Л. Бризола заявил, Імет все меры, чтоть попыткам отстрагасти виче-президенга. По неподтверведениям, говорится и, авианосец и три оенно-морских сил аходятся на пути $\mathrm{k}$ кного штата Риоул. Наблюдатели то военные корабгены на юг ждля әния беспорядков» єли Гуларту помепрезидентом. резервистов, «По-видимому, вызовет неудовольствне в Baшинтгоне.

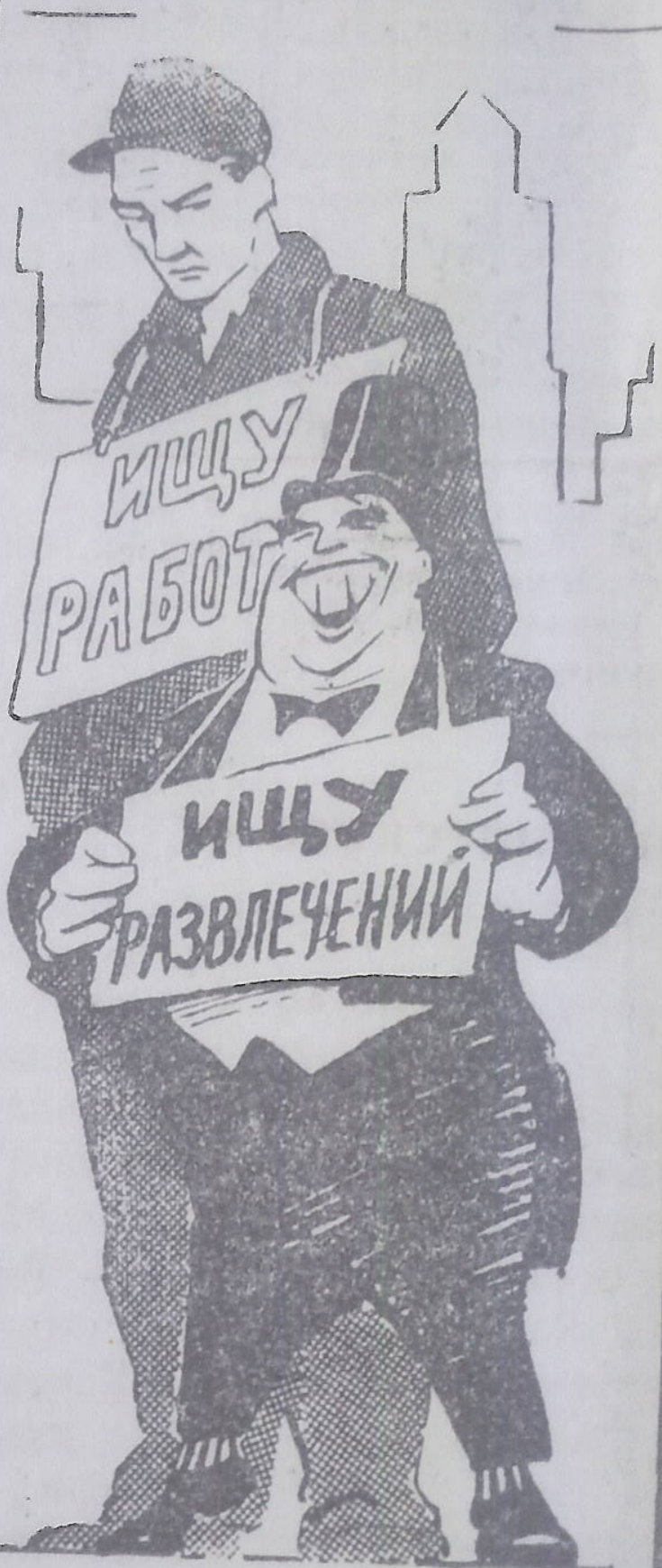

Востеваемое «благоденствие» буржуазного строя-это благоденствие для кучки капиталистов и муки, страдания для сотен миллионов людей труда. Рис. С. ЧИСТЯКОВА.

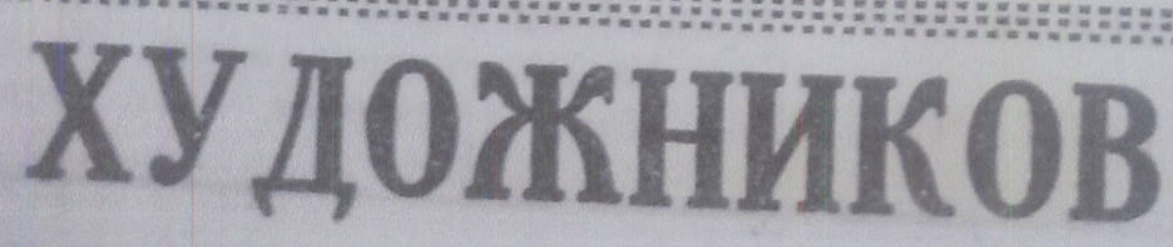

первенство CCCP по Q команд класса «A».

Команда ЦСКА встр с футболнстами харьк «Авангарда». Интересн ра закончиласв со счет в пользу москвичей.

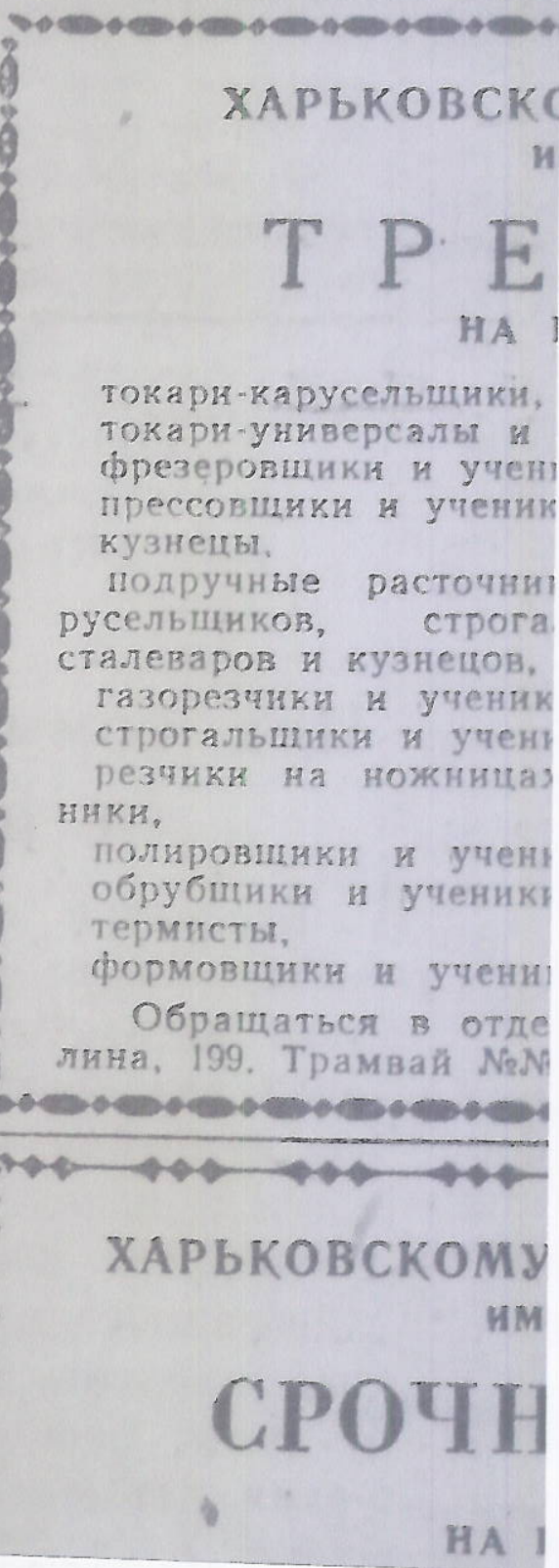

Figure 2. Chistyakov, C. "Looking for a Job. Looking for Entertainment." Krasnoe Znamya [Kharkov] 29 August 1961: 4. Print.

The celebrated "prosperity" of the bourgeois system means prosperity for a small group of capitalists and sorrow and suffering for hundreds of millions of working people.
TP токарк-каруселиники, фрезеровщики и учен русельшиков, строга газорезчики и ученик

\section{4}

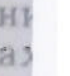




\section{ПОДОВРАНА}

НБЮ-НОРК, 13 сентября. (ТАCC). Амернканские инфор мапнонные агентства сообщают с мыса Канаверал. что капсу ла с емеханическим космонав тому, совершив один оборот вокруг Земли, опустилась на парашюте в Атлантический океан в районе Бермудских ос. тровов, где была подобрана американским эсминщем. Для того, птобы извлець ее из во ты, понадобнлось 84 минуты. Толет по орбите продолжаля I час 46 мннут. Вес капсулы тоннь.

$$
-0=0
$$

\section{Хвастливое заявление}

\section{мериканского генерала}

БОНН, 14 сентября. (ТАСC). Мандующий вооруженными пами США в Европе генеЛ Кларк заявил вчера в йдельберге, घто подчиненные войска получили самое ременное оружие и воен оборудование. Согласно бщению агентства ДПА, арк сказал, что американе воинские подразделения Западном Берлине, которые же получили новое вооруне, оснащены в настоящее мя так, что они «могут вынить свою миссиюж.

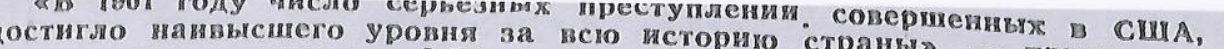
своем докладе директор ФбР (тайная иолиияя)

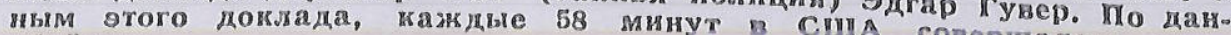
убийство.

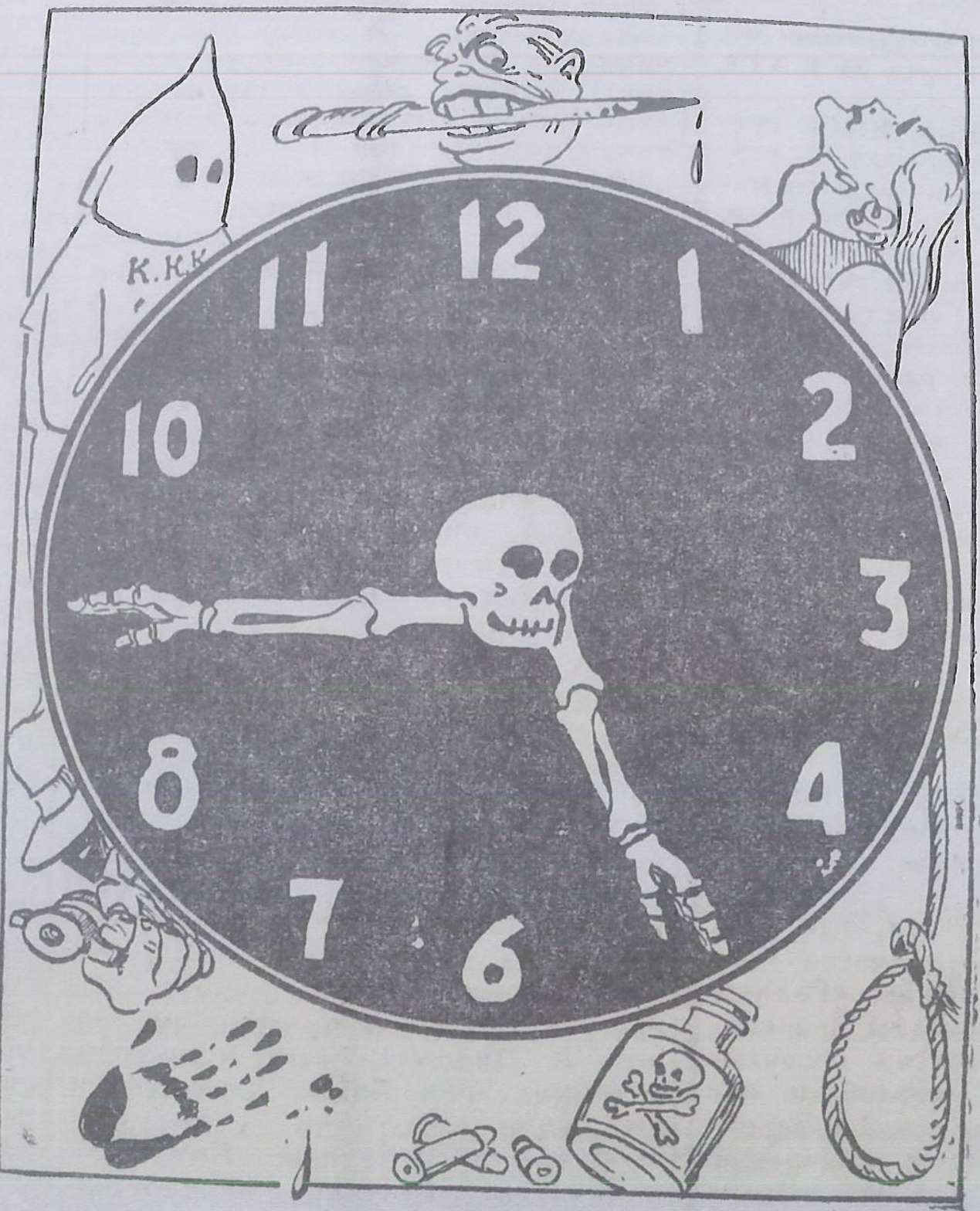

Американские часы. неральнои Ас на сессии Ге- : Насколько Ассамблеи ООН, : нистр иностранизвестно, мик : ко также будет дел Громына сесски, Әто присутствовать можность даст нам возговоров пол серьезных перегим проблемамманской н дру-

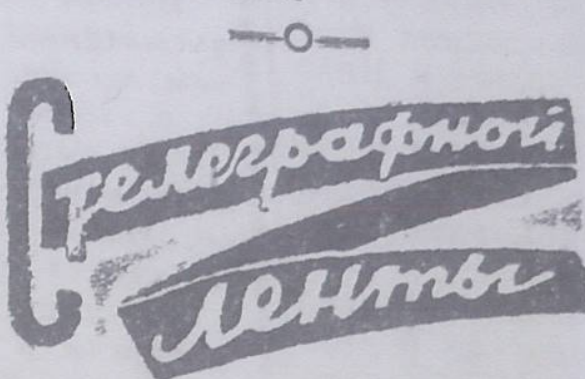

\%: ПРАГА. В Братиславу прнбы ла находящаяся в Чехословакии делегация Верховного Совета СССі во главе с В. В, Гришиным Бра тиславские трудящиеся, кақ, сооб щает Чехословацкое телеграфюь агентство, устроили дорогим гос тям горячий, братский прнем.

\%: ПАРКЖ, Серьезные столкнове ния между европейцами и алжирцами произошли в алжирских квар талах Баб-эль-Уэдд (г. Алжир) Группа белых расистов организо вала настоящую охоту за людьм в кварталах, населенных алжирца ми. Многие из местных жителей стали жертвами суда Линча, По данным агентства Франс Пресс, в результате спровоцированных расистами столкновений было убнто 10 алжирцев и ранено 17.

Ұ: КОПЕНГАГЕН. Датскне газеты сообщают, что в районе Север ной Европы начались военно-воздушные маневры НАТО под услов ным названием Чекмейт 13, Тазета «Берлингке тидендез указывает, qто эти военно-воздушиые маневры НАТО продлятся 4 дня й охваты вают район Данин, Норвегиц й восточной шасти Атлантнческого океана,

Figure 3. Grunin A. "The American Clock." Krasnoe Znamya [Kharkov] 15 September 1961: 4. Print.

"In 1961, the number of serious crimes committed in the USA reached the highest level in the history of the country," admits in his report Edgar Hoover, director of the FBI (secret police). According to this report, a murder is committed in the USA every 58 minutes. 
Figure 4. "Bloody Dictator and His Support." Krasnoe Znamya [Kharkov] 15 March 1961: 3. Print.

Franco's regime depends on the support of the USA and West Germany, which is provided in return for the military bases in Spain.

ли, заведуюиикума будут ть на места ремя работы еся перейдут профссюзные й. мы понинимает отзенных оргальзя забыгевушек, пеодин год, на очередь цагогический павить вею: с әтой груповском совзнную рабочащиеся чеПоллективы ре уже сдеу важному өсти. Надо ать, qтобы документа-

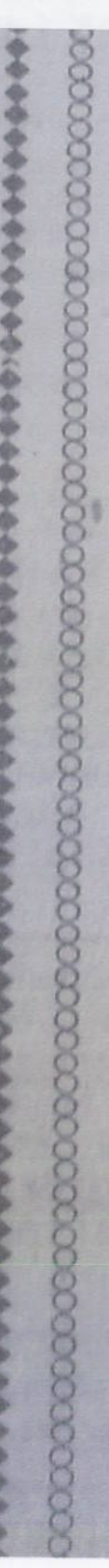
Западнй базы в Испакии.

\section{.}

\section{.}

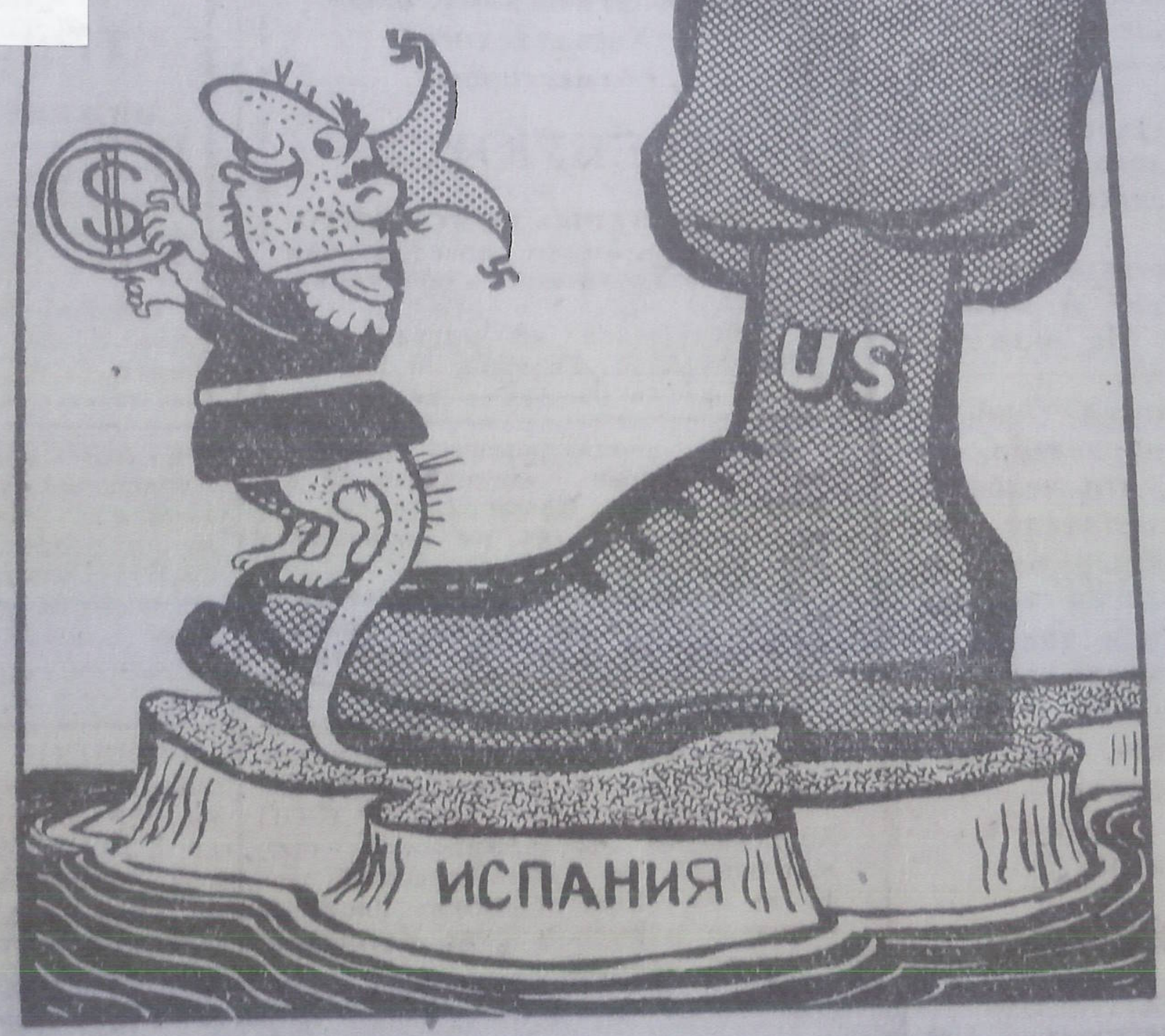

Кровавый диктатор и его onopa.
Фетохроника ТАСС. ла Хойзинтера. продолжение

устрашения и

будто путь к

лежит через й

усиления гонки

Штраус и Хo ставшей модно «пересмотра»

высказываются

Больше того.

чTO «E'O BTODO

война перес

средством пол

нерал делает

стремится дон

положное.

Хойзннгер,

ной формой

лается выво

раз вооружа

Еойны, В том

ными. В во

по словам

быть разлия

ным и обыч

И Штраус

мысль о тол

родных

прийти воор

«Мы дол

3АПA

MOHTEB Западная тығать ур Перу, о6 Перу,
ская raset 


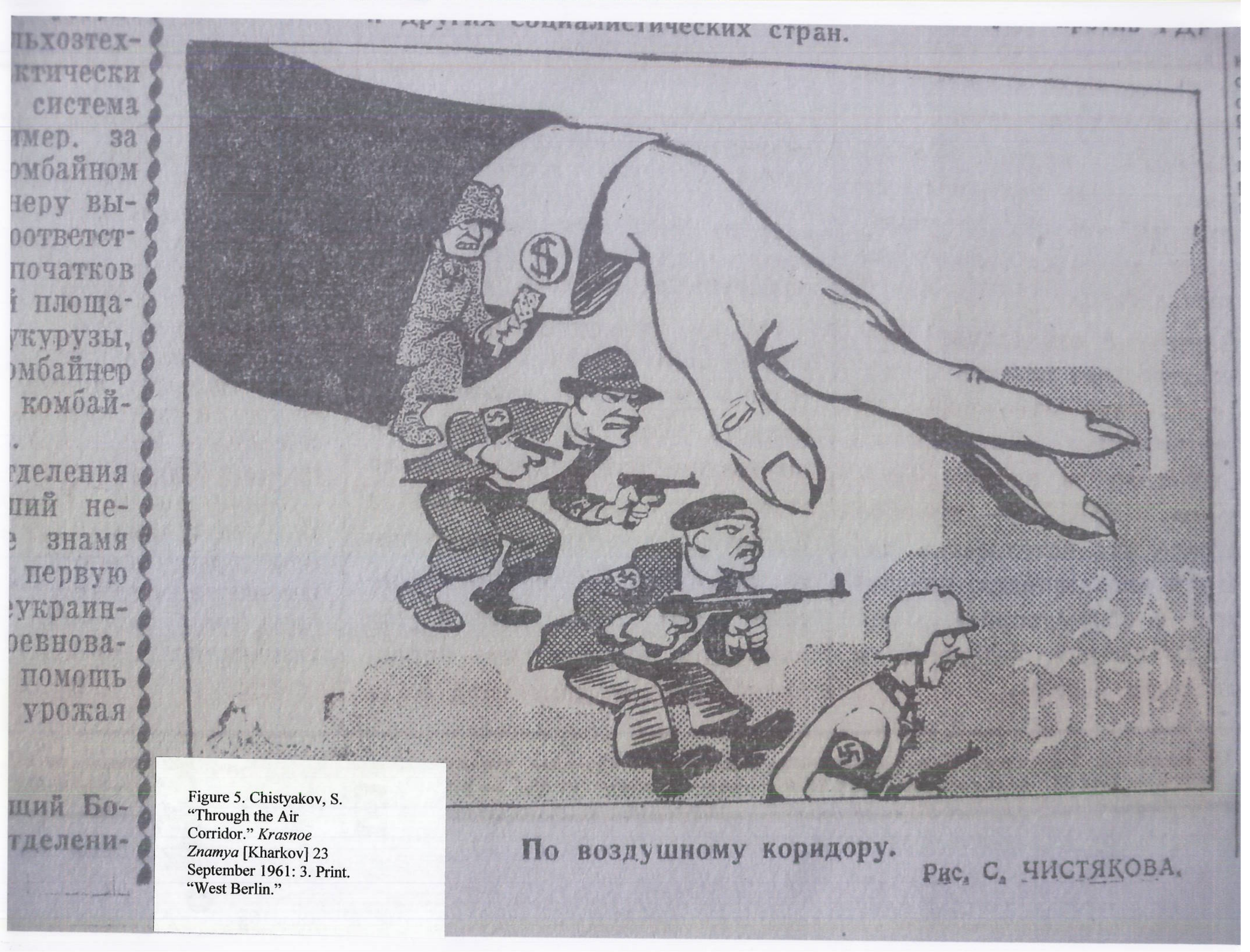



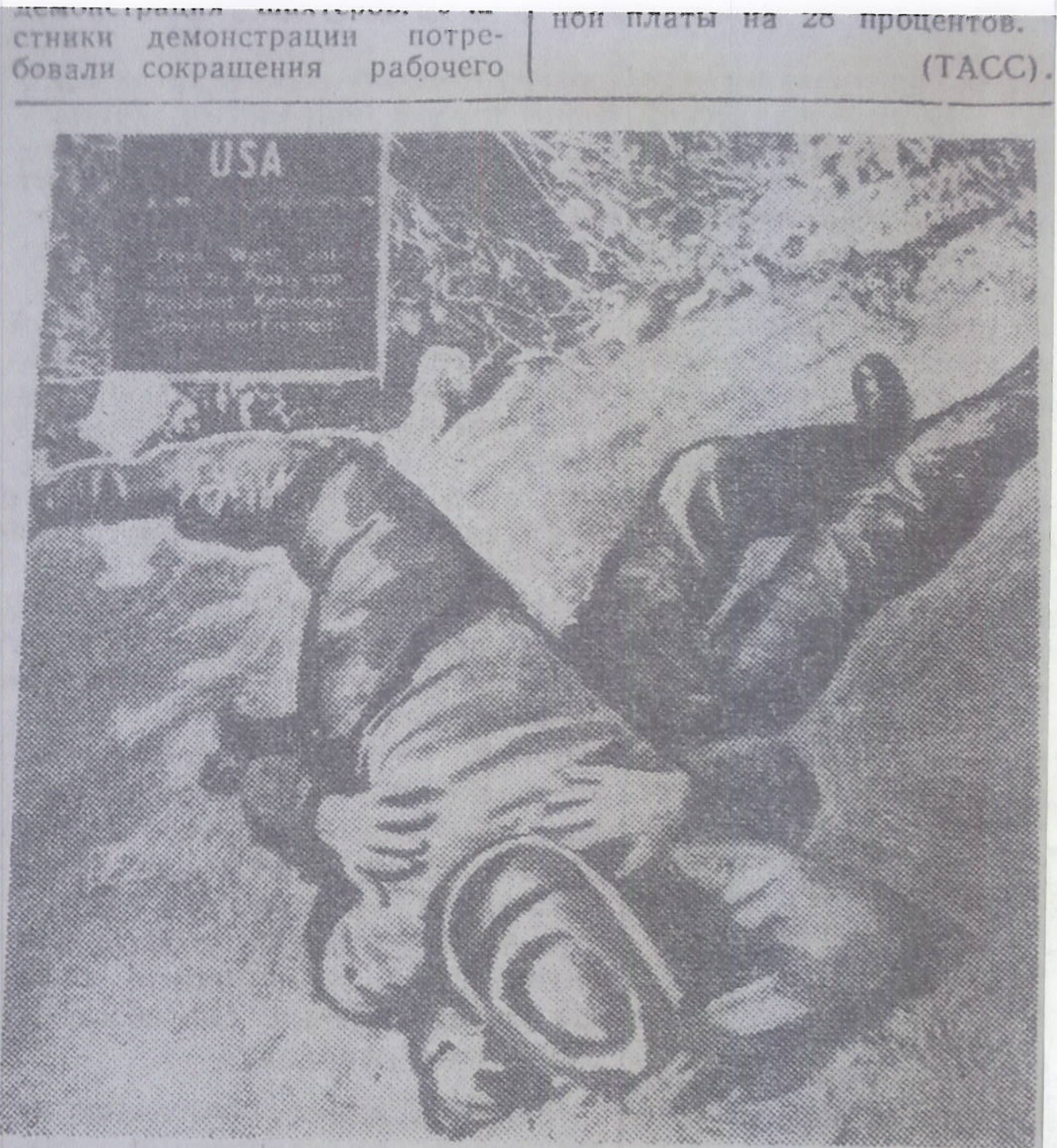

Соединенные Штаты Америки. Форт Брагга в штате Сeверная Каролина. Здесь в специальной, совершенно засекреченной «школе» готовят так называемых «партизан». Они осванвают средства и способы сделать человека «абсолютно безвредным», то есть убить. Они изучают воздействие ядов, бесшумное оружие, приемы, как зарезать или задушить противника вбез звукар.

Журнал «Фрайе вельт», публикующий этот снимок, указывает, что так выглядит на практике «доктрина свободы» президента Кеннеди.

Эти «партизаны» предназначаются для борьбы с национально-освободительным двнжением. В газетах США называют возможиые места действий гангстеров - Вьетнам, Лаос, Кубу и страны Центральной Америки.

Можно понять, какую участь молодежи готовят генералы Соединенных Штатов Америки, если такие «занятия» проводятся в «школе».
Figure 6. "United States of America. Fort Bragg in North Carolina." Krasnoe Znamya [Kharkov] 6 August 1961: 4. Print.

United States of America. Fort Bragg in North Carolina. Here, in a special, top secret "school" so-called "guerrillas" are trained. They master methods and means of rendering a person "absolutely harmless," that is of killing. They study effects of poisons, noiseless weapons, modes of stabbing and strangling the enemy "without a sound."

Freie Welt magazine, which published this photo, points out that this is what President Kennedy's “freedom doctrine" looks like in practice.

These "guerrillas" are destined for fighting national liberation movements. USA newspapers mention possible scenes of action for the gangsters -

Vietnam, Laos, Cuba, and countries of Central America.

It is clear what fate the generals of the United States of America are preparing for the youth if such "classes" are conducted in a "school."

$\left\{\begin{array}{r}\text { томашиниста. } \\ \text { - Для пы можем ра } \\ \text { же } 125 \text { кнло } \\ \text { ничиваем н с } \\ \text { Так залви. } \\ \text { года Нван } \\ \text { ный, началь } \\ \text { танцин пут }\end{array}\right.$

Адрес релакцин: Геспром, 4-คै пелъезд, 3-й ттак. Телефоны: редактор - 3-14-2: -тдел васем - 8-44-41. селькозетдел - 3-18-41. пром,-транеn. ота 


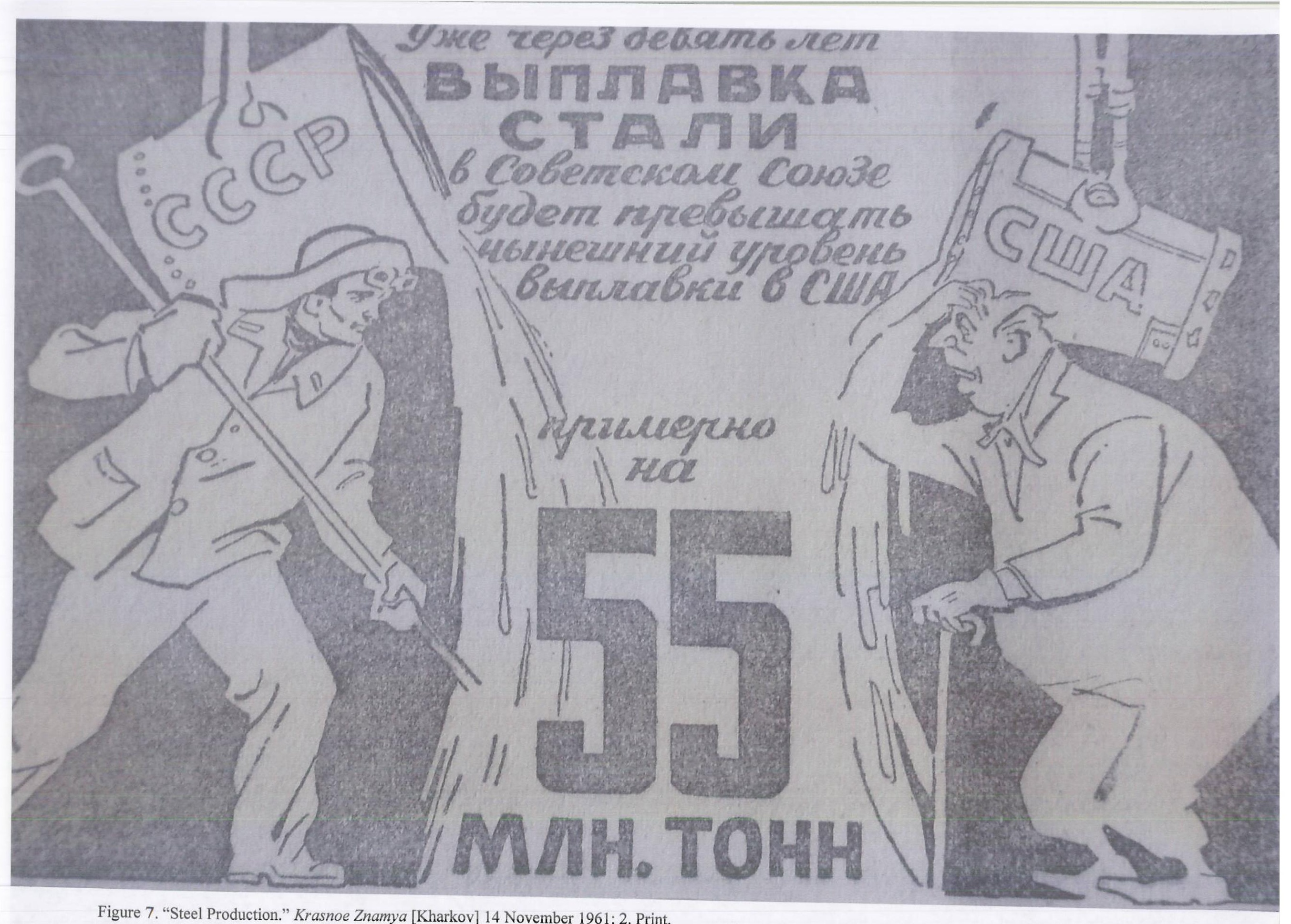

Figure 7. "Steel Production." Krasnoe Znamya [Kharkov] 14 November 1961: 2. Print.

As early as in nine years from now, steel production in the Soviet Union will exceed the present level of the USA by approximately 55 million tons. 
сают преподавателей и студенБак правило, они проходят в нужтенной обстановке. И саажное - они без сомнения ствугт воспитанию подлинно пектуальных людей. культуртепиалистов. Растет и крепнет . дружба разных поколений. ужба взаимовыгодна: отдавая мододежи. мы многое от нее чаем. Дружеское обтение пес молодежью просто необОно. мне думается, избавсостояния неподвижности, сти. пассивности, вамкнуто торые бывают, когда прөфеси препөдаватель является 를

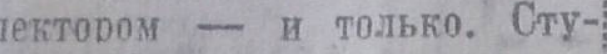
же сближение с людьми с 1 жизненным опытом помости. ширить свой круговор. гонтакт вовсе не следует ть с панибратством, он не ни малейшето умаления датога как руководителя и днтеля.

сиваясь с мөлодыми спешиа- выпускниками нашего

Figure 8. Ognivtsev, N. "Parasitic Tumor." Krasnoe Znamya [Kharkov] 20 September 1961: 3. Print.

Monopolistic bourgeoisie has become a redundant tumor on the body of the society, useless for the process of production. Plants and factories are managed by hired directors, engineers, and technicians. The monopolists lead a parasitic life, consuming, together with their servants, a considerable portion of the national income that is created by the labor of workers and peasants.

From the draft of the Program of the Communist Party of USSR

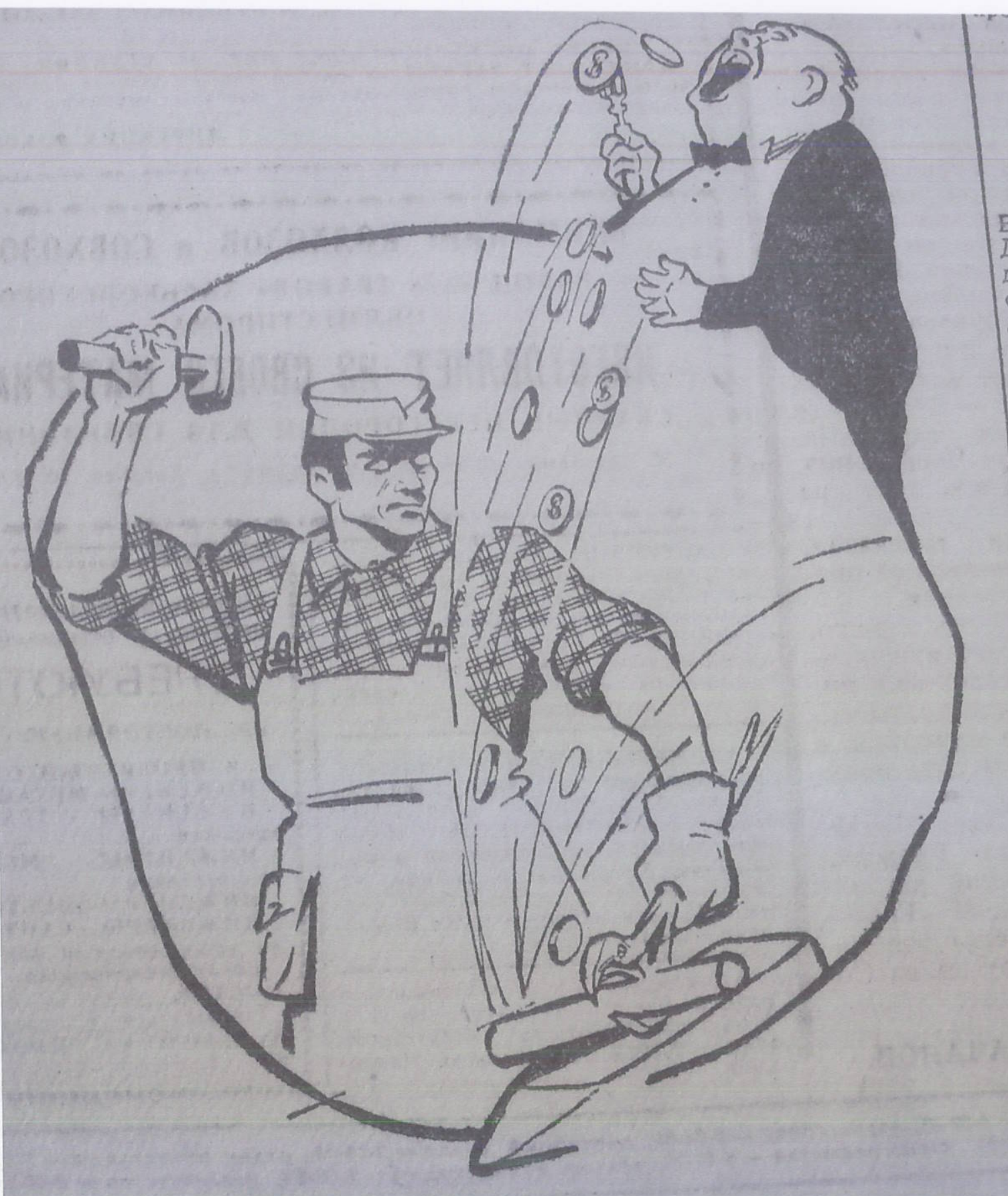

3АМЕЧАТЕЛЬНАЯ ДEMOKP

БЕРЛИН, 18 сентября Вчера, 17 сентября, в Демократической Респуб. дили выборы в местные сти. Әтот день превратн линный народный празд щиеся шли на избирател ки семьями, целыми к со знаменами, с рапор довых победах. В течен в парках, на улицах городов и сел звучал песни.

По предварительны выборах приняло уча центов избирателей. I дидатов Национально зал корреспонденту Т мунистической партии 1918 года, а ныне чл тав Бернсдорф, наи ляет, पто он сам $\mathrm{xc}$ государстве и хочет строить новую жиз

\section{ЗАСЕДАНИЕ}

БЕРЛИН, 18 Сегодня состоялось дарственного совет шенное результатам ные органы власти сударственный сов боры, как показа гражданами ТДР ской власти, чспе ПТаразитнческий нарост. ской власти, успеу PMC, $H$. OIHUBLEBA 


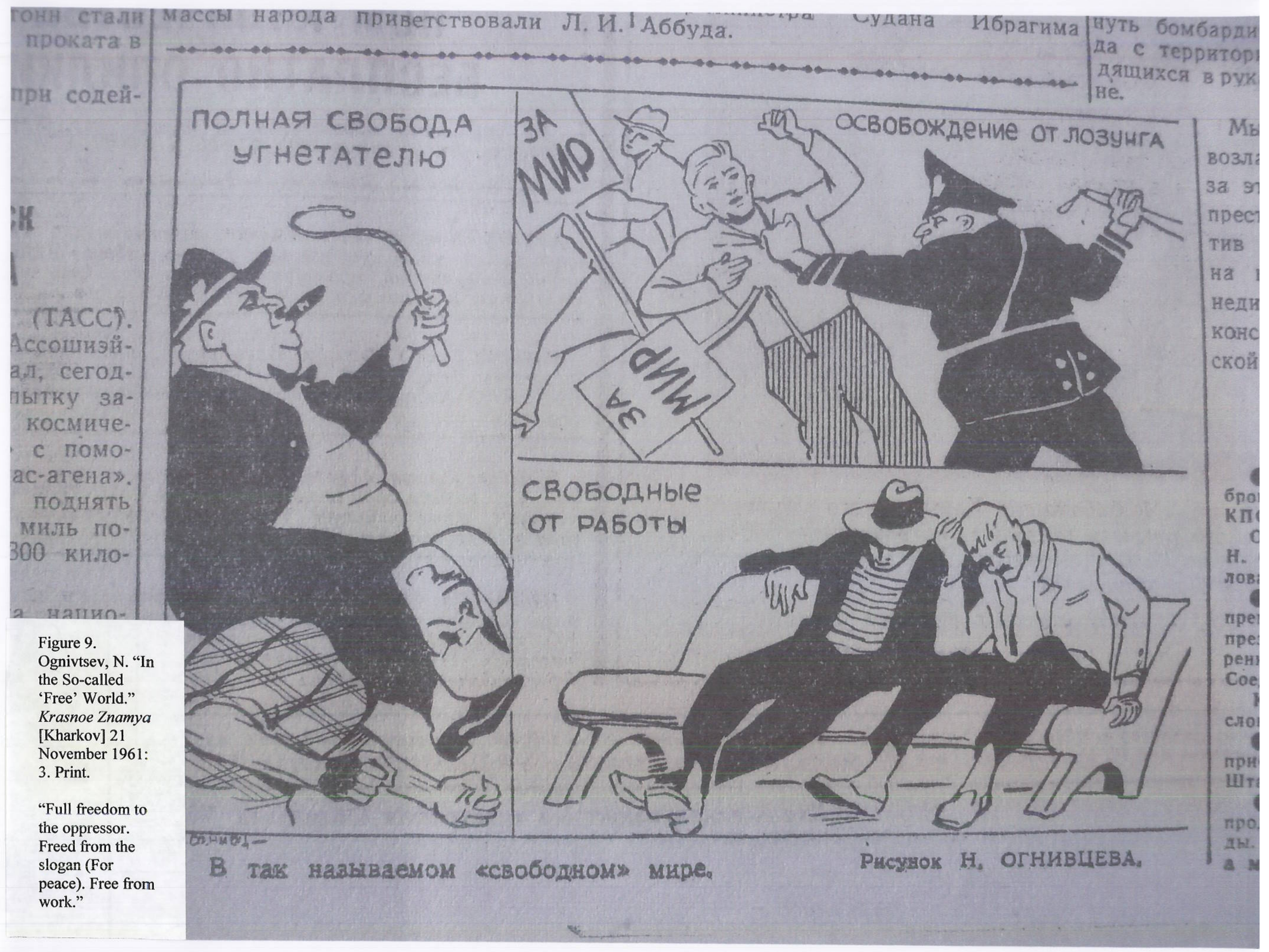




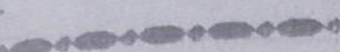

Мало кто говорит теперь за границей, что мы фантазеры. Даже многие буржуазные деятели. ослепленные классовой ненавистыб, к нашей населения Соедияенитывают тоды, когда мы доНз речи Н. С. Хрущсва на январском пленуме ИК К

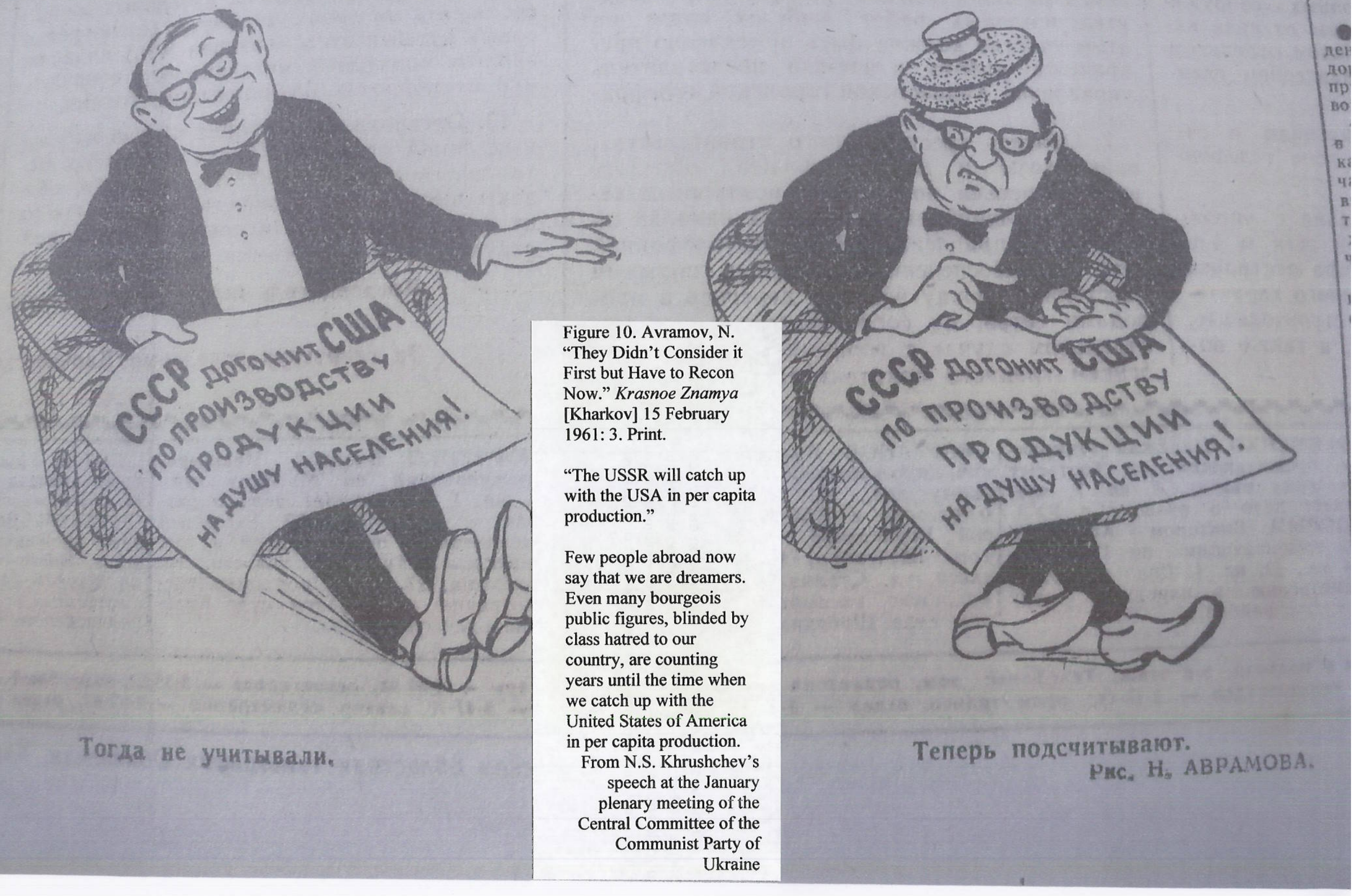




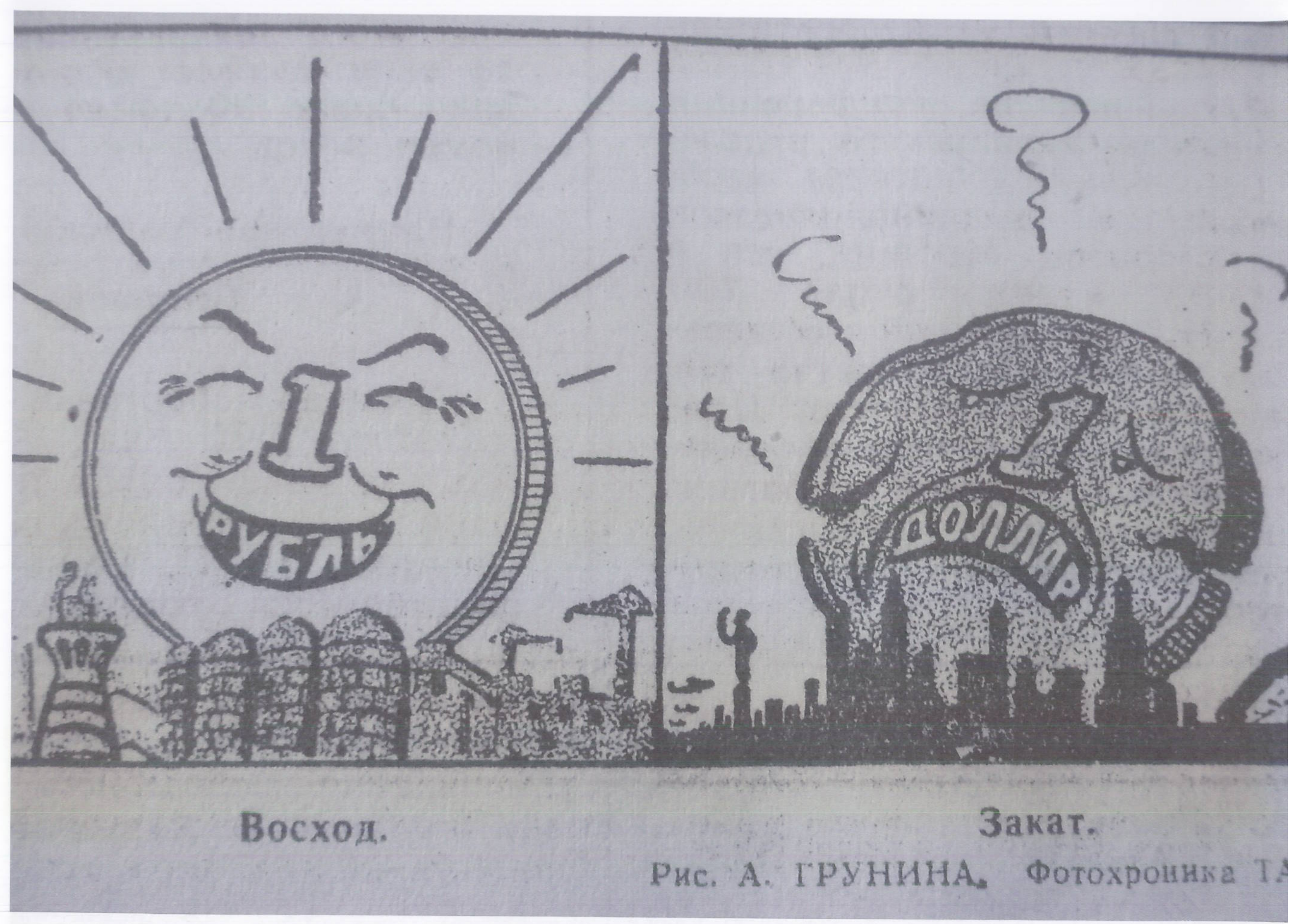

Figure 11. Grunin, A. "The Rise of Ruble; the Decline of Dollar." Krasnoe Znamya [Kharkov] 3 January 1961: 3. Print. 
Figure 12. "Merchant Marines on Strike." Krasnoe Znamya [Kharkov] 29 July 1961: 3. Print.

Strikes of merchant marines are going on in the United States of America. The strikers demand pay increase and improvement of work conditions. According to the received reports, the number of seamen on strike exceeds 80,000 . In the picture: police are breaking up a picket of strikers near an oil refinery in New Jersey.

(Photo received over the radio)

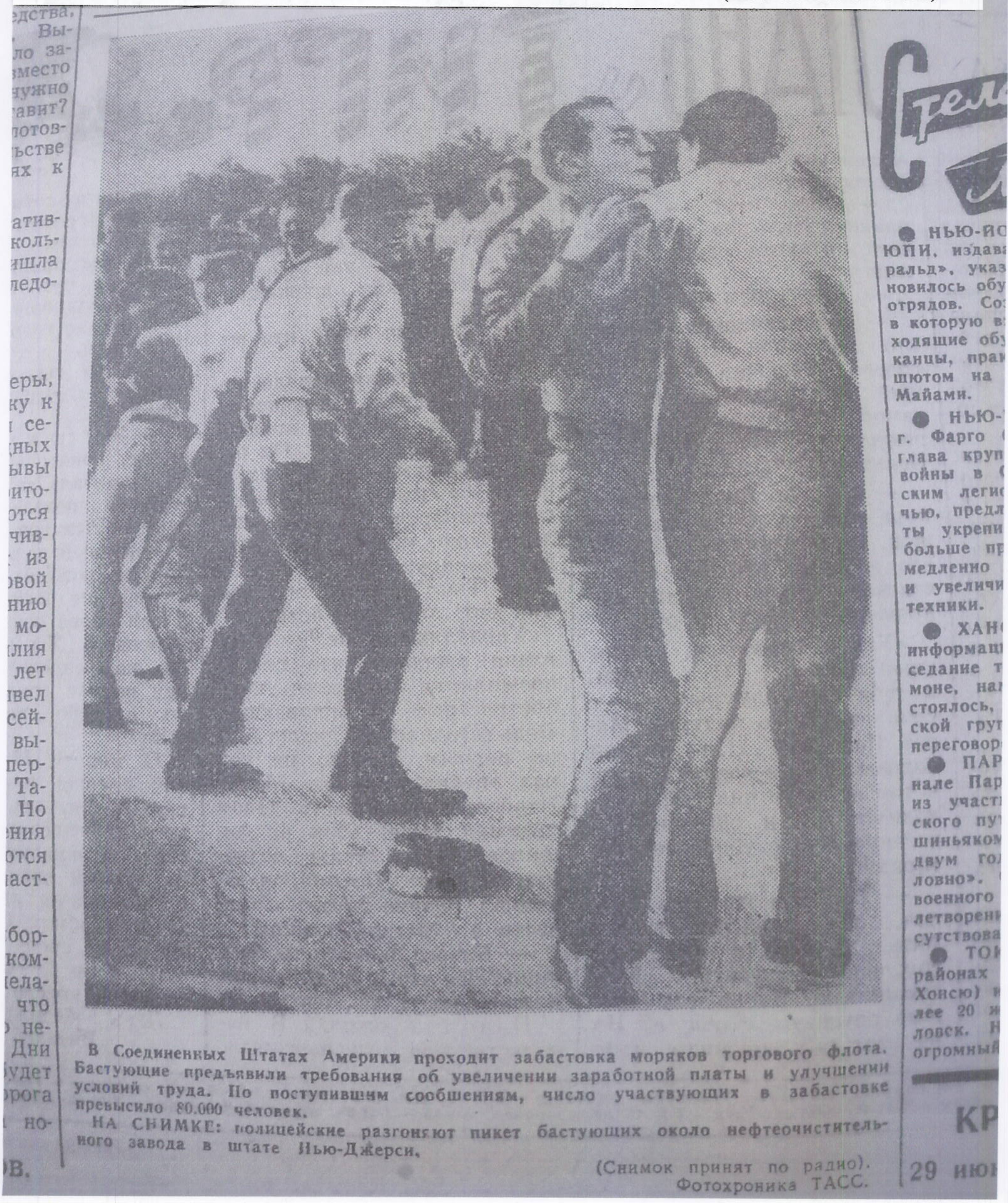




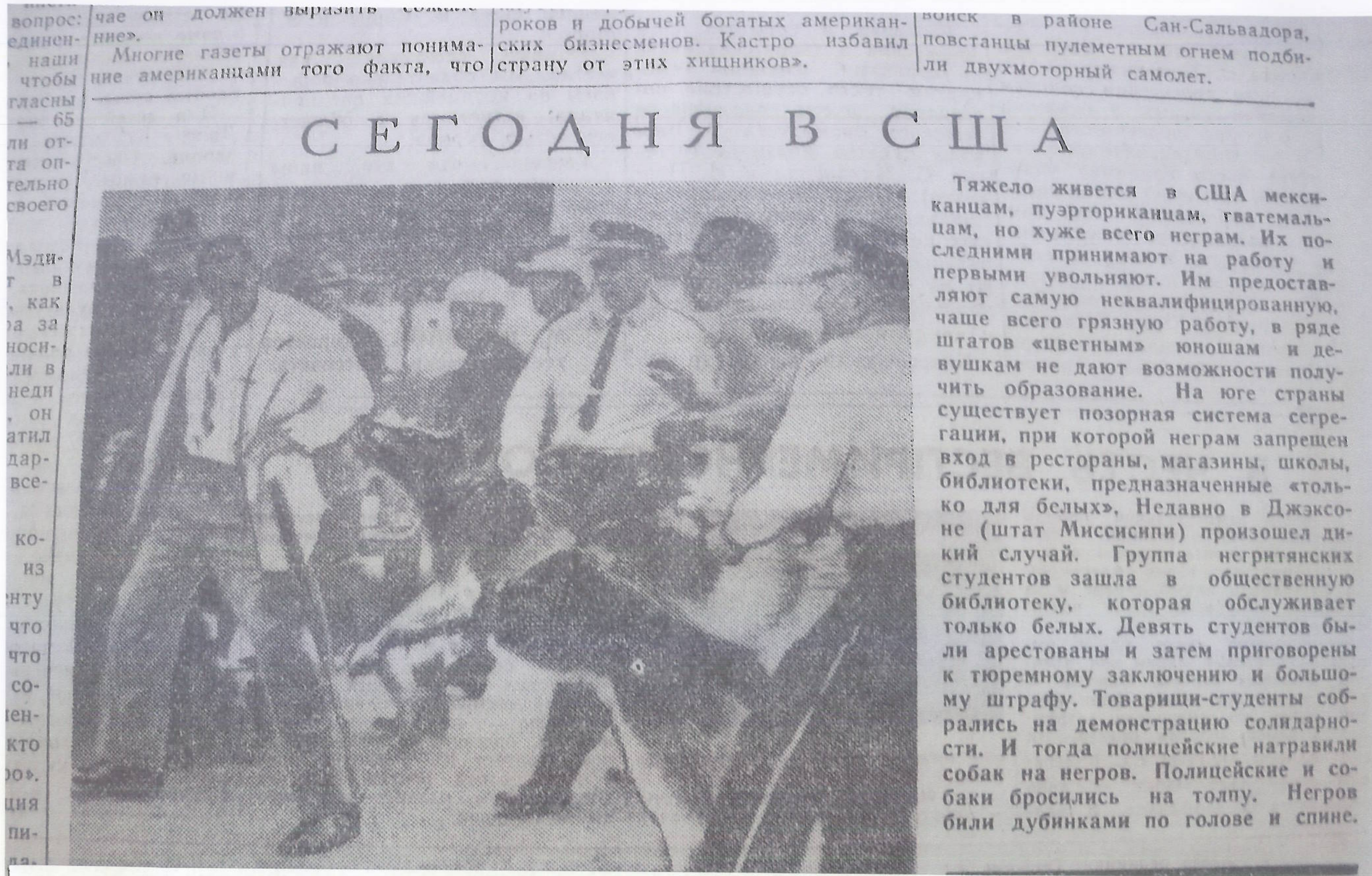

Figure 13. "Today in the USA." Krasnoe Znamya [Kharkov] 13 May 1961: 3. Print.

In the USA, life is hard for Mexicans, Puerto-Ricans, Guatemalans, and especially for Negroes. They are the last to be hired and the first to be fired. They are given the least skilled, most often dirty work; in a number of states, "colored" young men and women do not have an opportunity to receive education. In the South of the country, there exists a disgraceful system of segregation, under which Negroes are not allowed to enter restaurants, stores, schools, and libraries that are designated "for whites only." This is what happened recently in Jackson (Mississippi). A group of Negro students entered a library that only serves whites. Nine students were arrested and sentenced to prison terms and large fines. Their fellow-students gathered for a demonstration of solidarity. And then the police set dogs on the Negroes. The policemen and the dogs attacked the crowd. The Negroes were beaten on their heads and backs with batons. 


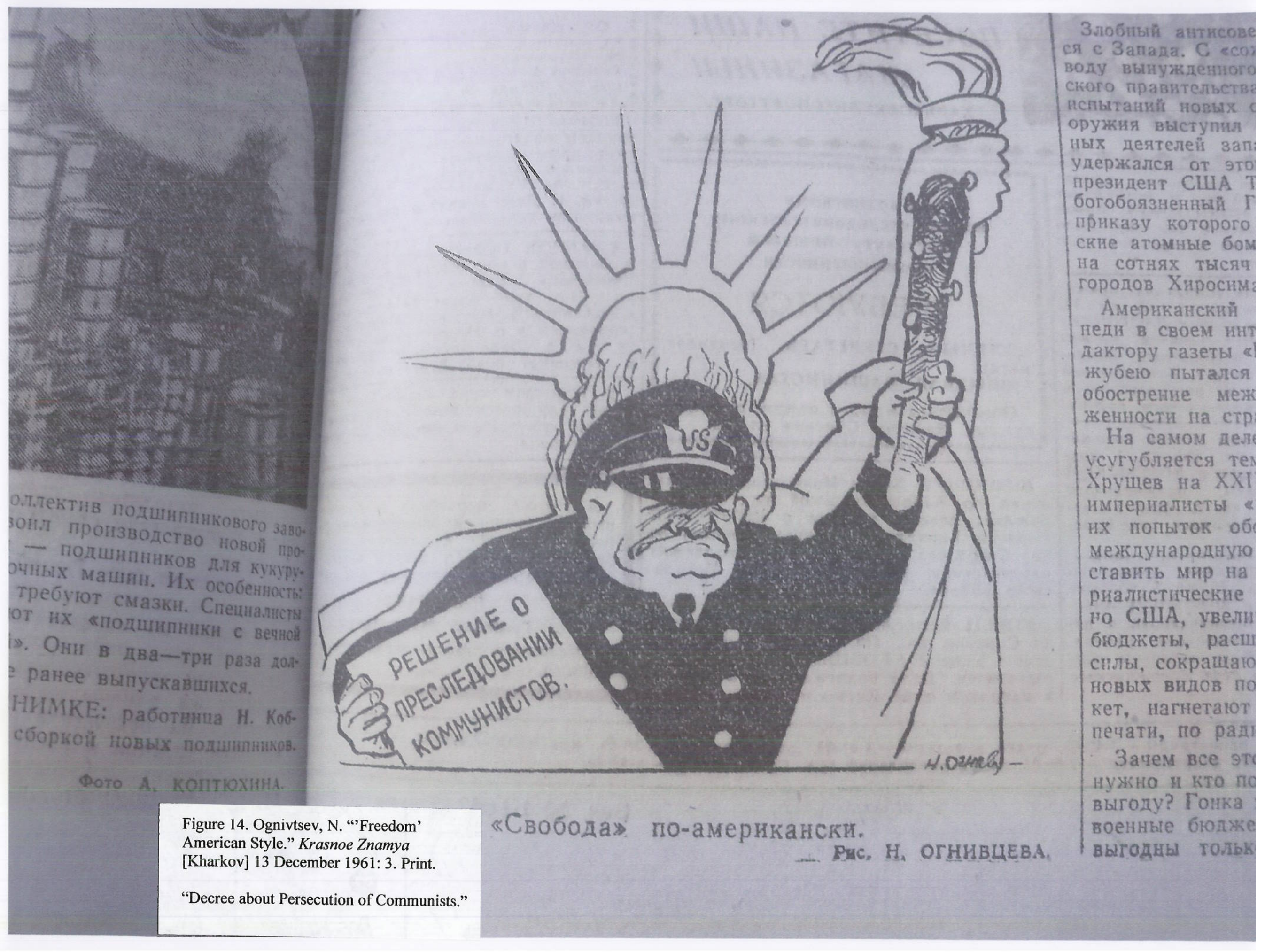

